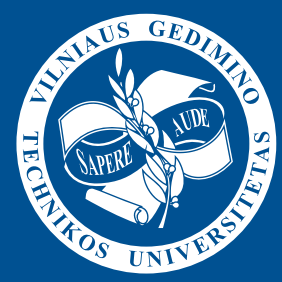

ISSN 1392-1436

\title{
Vilniaus Gedimino technikos universitetas 2014 metai
}

Mokslas, studijos, universiteto gyvenimas
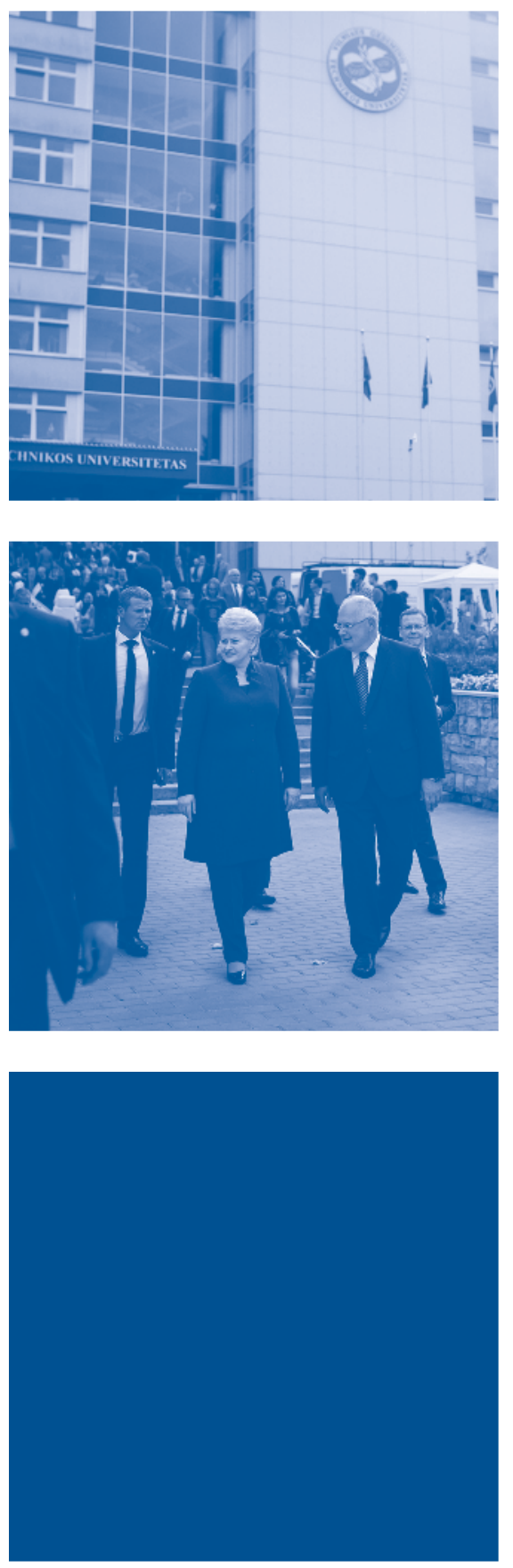

Nr. 48, 2015
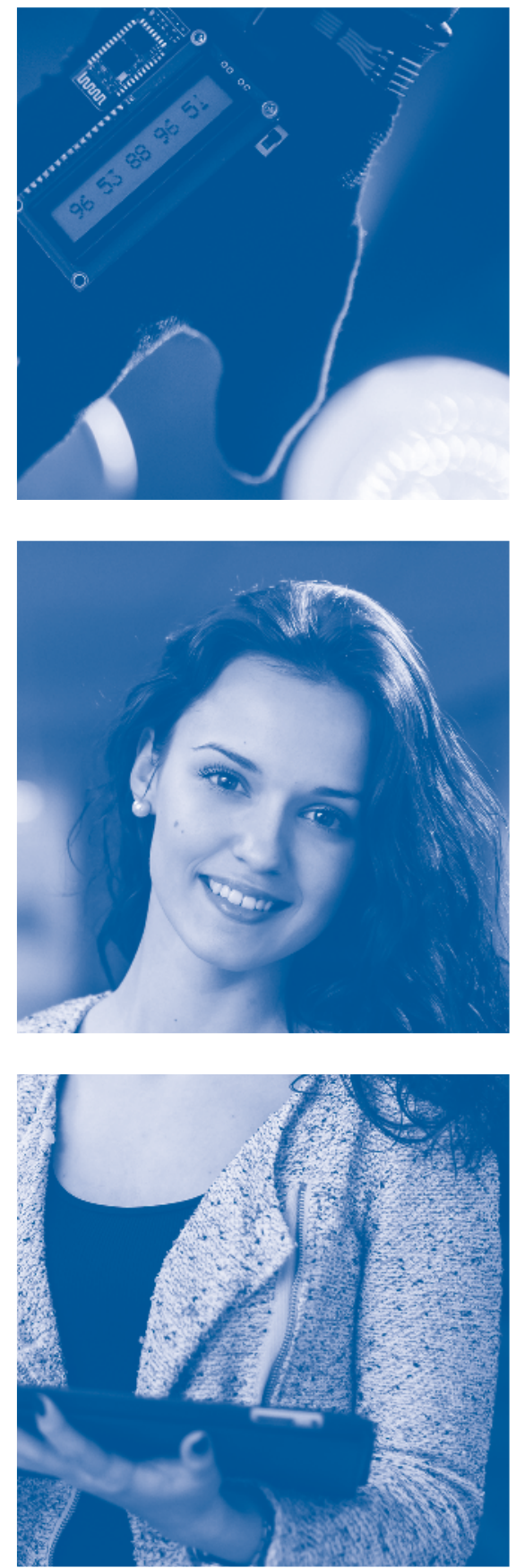


\section{Vilniaus Gedimino technikos universitetas 2014 metai}

Mokslas, studijos, universiteto gyvenimas Nr. 48, 2015 
Mokslas, studijos, universiteto gyvenimas Nr. 48, 2015

Vilniaus Gedimino technikos universiteto mokslinis informacinis leidinys

\section{Redakcijos kolegija:}

prof. dr. Donatas Čygas, vyriausiasis redaktorius;

prof. habil. dr. Antanas Čenys;

prof. dr. Alfonsas Daniūnas;

prof. dr. Romualdas Kliukas;

doc. dr. Arūnas Komka;

prof. dr. Alfredas Laurinavičius;

doc. dr. Asta Radzevičienè. 


\section{Turinys}

\section{Pratarmè / 5}

1. Valdymas ir struktūra / 9

2. Strateginiai universiteto prioritetai / 17

3. Studijos ir mokymasis visą gyvenimą / 21

3.1. Studijų prioritetai ir plètra $2014 \mathrm{~m}$. / 21

3.2. Studijų sistema / 21

3.3. Studijų programos / 23

3.4. Studijų organizavimas / 31

3.5. Studentų ir absolventų skaičius / 35

3.6. Prièmimas i pirmosios pakopos studijas / 43

3.7. Prièmimas ị antrosios pakopos studijas / 47

3.8. Studijų tarptautiškumas / 49

3.9. Studentų karjera ir ịsidarbinimas / 55

\section{Moksliniai tyrimai ir inovacijos / 59}

4.1. Mokslo ir technologijų prioritetai ir plètra $2014 \mathrm{~m}$. / 59

4.2. Mokslo pasiekimai ir inovacijos / 61

4.3. Doktorantūra ir tyrèjų ugdymas / 70

\section{Poveikis regionui ir šalies raidai / 75}

5.1. Universitetas regionui, valstybei ir miestui / 75

5.2. Bendradarbiavimas su mokslo ir kitais socialiniais partneriais / 77

5.3. Universitetas moksleiviams / 78

6. Administravimas ir ištekliai / 83

6.1. Prioritetai ir plètra 2014 / 83

6.2. Kokybès vadybos sistemos diegimas / 83

6.3. Žmogiškieji ištekliai / 84

6.4. Ekonomika ir finansų valdymas / 89

6.5. Universiteto infrastruktūra / 94

7. Visuomeniškumas / 117

8. Svarbiausi 2014 metų ìvykiai / 127

\section{Priedai $^{*}$}

\footnotetext{
* Priedai pateikiami VGTU interneto svetaineje kartu su visa ataskaita
} 



\section{Pratarmè}

Pagrindinius strateginius Vilniaus Gedimino technikos universiteto veiklos prioritetus iki 2020 m. apibrèžia 2014-2020 metu VGTU plètros strategija. Pagrindinès strategijoje įtvirtintos veiklos plètojimo kryptys yra kvalifikuotų, konkurencingų specialistų rengimas, tarptautinio lygio mokslinių tyrimų vykdymas siekiant lyderystės Baltijos šalyse pagal prioritetines kryptis, inovaciju plètra prisidedant prie darnaus šalies ir regiono vystymosi. Šiems uždaviniams spręsti 2014 m. ir buvo sutelktas Vilniaus Gedimino technikos universiteto mokslininkų, pedagogu ir administracijos darbas.

2014 metai Vilniaus Gedimino technikos universitetui buvo sėkmingi, bet kartu ir ịvairūs: turime kuo didžiuotis, tačiau kartu yra dalykų, kuriuos dar turime taisyti ir tobulinti. Universitetą savo studijoms pasirinko daug kūrybingo jaunimo, pagal gautų valstybės finansuojamų vietų skaičių buvome vienas iš pirmaujančių tarp Lietuvos universitetų, išlaikėme lyderių pozicijas pagal studentų ir dėstytojų mainus. Didžiulę pažangą padarème tam tikrų krypčių mokslinių tyrimų srityje.

Sėkmingą universiteto veiklą charakterizuoja ir Tarptautinio universitetų reitingo "QS World University Rankings“ sudarytoju paskelbtas „2014-2015 m. Emerging Europe and Central Asia“ universitetų reitingas du Lietuvos universitetai, iš jų ir Vilniaus Gedimino technikos universitetas, pateko tarp regioninio reitingo 50-ies geriausiujų. Tai dar kartą patvirtino, kad universiteto veikla plètojama sėkmingai.

Alfonsas Daniūnas,

VGTU rektorius 



\section{Valdymas ir struktūra}
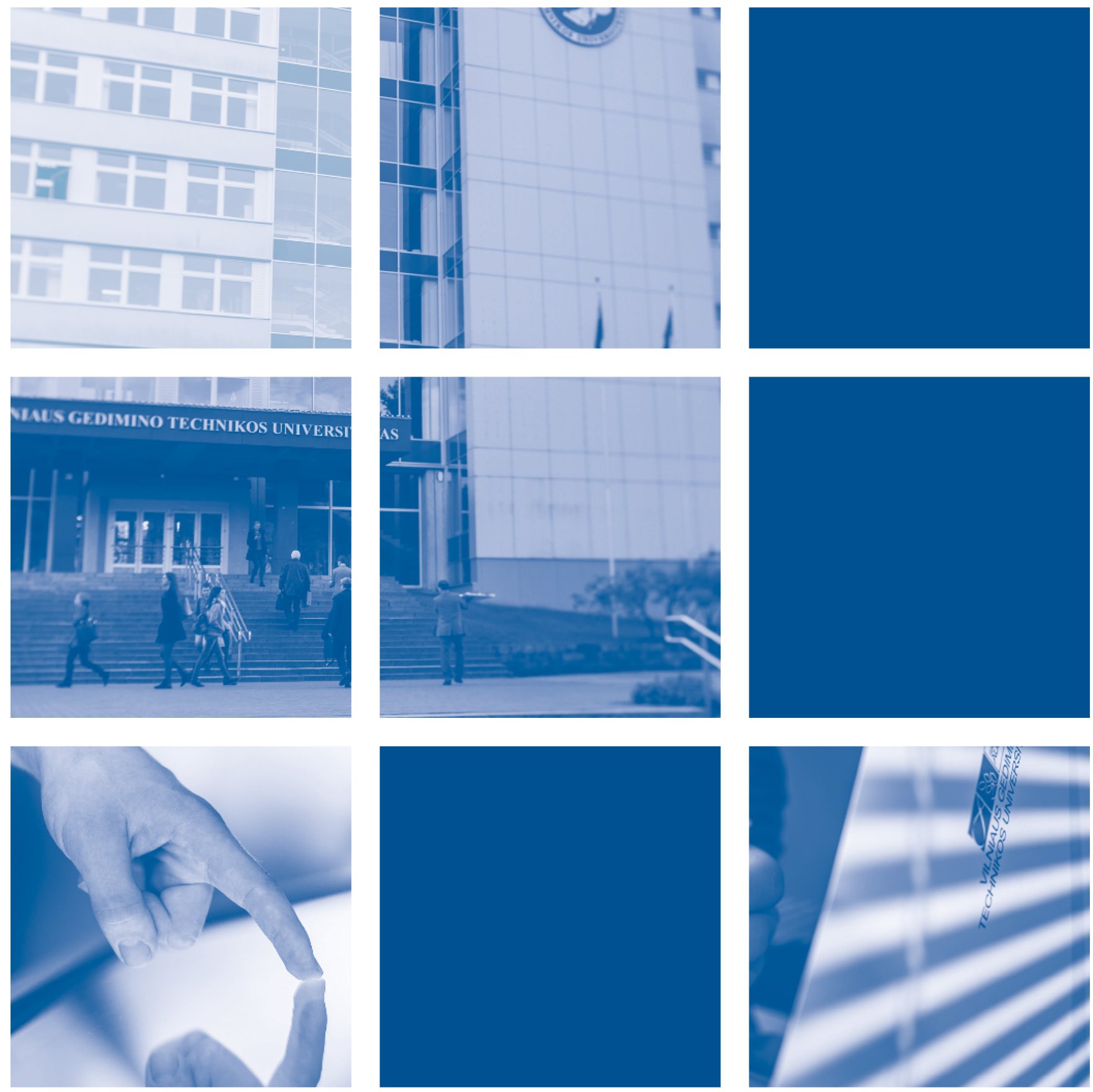



\section{Valdymas ir struktūra}

\section{Taryba}

Vilniaus Gedimino technikos universiteto Senatas, vadovaudamasis Lietuvos Respublikos mokslo ir studiju istatymo (Žin., 2009, Nr. 54-2140; 2012, Nr. 13-554, Nr. 53-2639) 20 straipsnio 3 dalimi ir nauja Vilniaus Gedimino technikos universiteto statuto redakcija, 2012 m. gruodžio 4 d. nutarimu Nr. 61-1 patvirtino Vilniaus Gedimino technikos universiteto Tarybą. Taryba išsirinko pirmininką ir pavaduotoją. Tarybos sudètis ${ }^{1}$ :

1. Tarybos pirmininkas Sigitas Leonavičius - UAB „Traidenis“ generalinis direktorius.

2. Tarybos pavaduotojas Artūras Abromavičius - UAB „Sweco Lietuva“ prezidentas.

3. Edita Karpavičienè - AB Ūkio banko Tarybos pirmininkè.

4. Algirdas Kaušpėdas - UAB „Jungtinès pajėgos“ direktorius.

5. Gintautas Kvietkauskas - UAB „Arginta“ gamybos direktorius.

7. Dionis Martsinkevichus - VGTU studentų atstovybės prezidentas.

8. Romualdas Kliukas - VGTU Fundamentinių mokslų fakulteto Medžiagų atsparumo katedros profesorius.

9. Alfredas Laurinavičius - VGTU Aplinkos inžinerijos fakulteto Kelių katedros vedèjas.

10. Artūras Kaklauskas - VGTU Statybos fakulteto Statybos ekonomikos ir nekilnojamojo turto vadybos katedros vedejas.

11. Algirdas Juozapaitis - VGTU Statybos fakulteto dekanas.

12. Edmundas Kazimieras Zavadskas - VGTU Statybos fakulteto Statybos technologijos ir vadybos katedros vedejjas, profesorius.

Taryba yra kolegialus universiteto valdymo organas, pagal kuri i valstybinių aukštujų mokyklų valdymą itraukiami ne tik akademinès bendruomenès, bet ir visuomenès atstovai. Ivertinusi Senato siūlymus, Taryba atlieka šias pagrindines funkcijas:

- tvirtina universiteto viziją ir misiją;

- teikia Seimui tvirtinti universiteto statuto pakeitimus;

- tvirtina rektoriaus pateiktą universiteto strategini veiklos ir plètros planą;

- nustato universiteto lèšų (taip pat lèšų, skirtų administracijos ir kitų darbuotojų darbo užmokesčiui) ir nuosavybės teise valdomo turto valdymo, naudojimo ir disponavimo jais tvarką;

- tvirtina Universiteto rektoriaus rinkimų viešo konkurso būdu organizavimo tvarką;

- nustato bendrą studijų vietų skaičių, atsižvelgdama i galimybes užtikrinti studijų ir mokslo, meno veiklos kokybę;

- tvirtina universiteto reorganizavimo arba likvidavimo planus ir teikia juos Seimui;

- svarsto ir tvirtina rektoriaus teikiamus universiteto struktūros pertvarkos planus;

- renka, skiria ir atleidžia rektorių;

- nustato universiteto administracijos ir kitų darbuotojų parinkimo ir vertinimo principus;

- tvirtina universiteto vidaus tvarkos taisykles;

- rektoriaus teikimu nustato studijų kainą ir i̇mokų, tiesiogiai nesusijusių su studijų programos igyvendinimu, dydžius;

- svarsto rektoriaus pateiktą universiteto metinę pajamų ir išlaidų sąmatą bei tvirtina šios sąmatos ịvykdymo ataskaitą;

- tvirtina rektoriaus pateiktą universiteto metinę veiklos ataskaitą;

- rengia metinę savo veiklos ataskaitą ir kiekvienais metais iki balandžio 1 dienos ją paskelbia viešai universiteto interneto svetainèje;

- atlieka kitas šiame statute ir kituose teisès aktuose nustatytas funkcijas.

Taryba veiklą vykdo vadovaudamasi Lietuvos Respublikos mokslo ir studiju istatymo (Žin., 2009, Nr. 542140; 2012, Nr. 13-554, Nr. 53-2639), Vilniaus Gedimino technikos universiteto statutu (Žin., 2011, Nr. 361700; 2012, Nr. 81-4230) ir Vilniaus Gedimino technikos universiteto Tarybos 2013 m. vasario 12 d. nutarimu Nr. 1-2 patvirtintu Vilniaus Gedimino technikos universiteto Tarybos darbo reglamentu.

1 Narių einamosios pareigos nurodytos tvirtinant Tarybą. 
2014 m. Taryba posėdžiavo penkis kartus ir prièmè šiuos nutarimus:

1. Dèl metinès Vilniaus Gedimino technikos universiteto veiklos ataskaitos.

2. Dèl Vilniaus Gedimino technikos universiteto 2013 m. pajamų (iplaukų) ir išlaidų sąmatos ịvykdymo ataskaitos ir $2014 \mathrm{~m}$. pajamu (iplaukų) ir išlaidų sąmatos projekto.

3. Dèl Vilniaus Gedimino technikos universiteto 2014-2016 metu strateginio veiklos plano patvirtinimo.

4. Dèl lèktuvų An-2 perdavimo Alytaus aeroklubui.

5. Dèl Vilniaus Gedimino technikos universiteto įmokų už pirmosios, antrosios pakopų ir vientisąsias studijas bei papildomas paslaugas apskaičiavimo tvarkos aprašo patvirtinimo.

6. Dèl trečiosios pakopos studijų kainų ir kitų imokų, tiesiogiai nesusijusių su studijų programos iggvendinimu, patvirtinimo.

7. Dèl premijų dydžių už Vilniaus Gedimino technikos universiteto aukštojo mokslo vadovėlius ir mokslines monografijas patvirtinimo.

8. Dèl Vilniaus Gedimino technikos universiteto Tarybos 2013 m. birželio 25 d. nutarimo Nr. 3-3 „Dèl Vilniaus Gedimino technikos universiteto pirmosios ir antrosios studijų pakopų užsienio studentų įmokų už studijas ir papildomas paslaugas apskaičiavimo tvarkos aprašo patvirtinimo“ pakeitimo.

9. Dèl Techninès kūrybos ir inovaciju centro steigimo.

10. Dèl Vilniaus Gedimino technikos universiteto Statinių skaitmeninio ir informacinio modeliavimo technologiju centro steigimo.

11. Dèl Edmundo Kazimiero Zavadsko kandidatūros pritarimo katedros vedèjo pareigoms.

12. Dèl Romano Martavičiaus kandidatūros pritarimo katedros vedèjo pareigoms.

13. Dèl Architektūros fakulteto Jaunojo architekto mokyklos likvidavimo.

14. Dèl Žinių ir technologijų perdavimo centro steigimo.

15. Dèl Vilniaus Gedimino technikos universiteto Kokybės vadybos skyriaus ir Strateginių tyrimų skyriaus pertvarkymo.

16. Dèl investiciju projekto „Vilniaus Gedimino technikos universiteto Elektronikos, Mechanikos ir Transporto inžinerijos fakultetų perkèlimas ị Saulètekio studentų miestelį“.

17. Dèl Vilniaus Gedimino technikos universiteto Mechanikos fakulteto Techninès kūrybos ir inovaciju centro studentų iniciatyvų rèmimo nuostatų tvirtinimo.

18. Dèl Vilniaus Gedimino technikos universiteto turto valdymo, naudojimo ir disponavimo juo tvarkos aprašo patvirtinimo.

19. Dèl Vilniaus Gedimino technikos universiteto profesoriaus emerito ir rektoriaus emerito išmokos dydžio nustatymo.

20. Dèl Vilniaus Gedimino technikos universiteto Aplinkos inžinerijos fakulteto Vandentvarkos ir Hidraulikos katedrų sujungimo.

21. Dèl Vilniaus Gedimino technikos universiteto Architektūros fakulteto Pastatų konstrukcijų katedros likvidavimo.

22. Dèl Vilniaus Gedimino technikos universiteto Tarybos 2013 m. lapkričio 26 d. nutarimo Nr. 5-6 „Dèl Vilniaus Gedimino technikos universiteto struktūrinių padalinių sąrašo patvirtinimo“ pakeitimo.

\section{Senatas}

Kaip ir ankstesniais metais, 2014 m. Vilniaus Gedimino technikos universiteto Senatas savo darbe nagrinejjo svarbius universiteto veiklos klausimus, prisėdejjo prie pagrindinių jo siekių ir uždavinių igyvendinimo.

Būdamas kolegialus universiteto akademinių reikalų valdymo organas, Senatas vykdo šias jam patikètas funkcijas:

1) tvirtina studijų, mokslinių tyrimų ir eksperimentinès (socialinės, kultūrinès) plètros, meno ir kitas programas, teikia rektoriui siūlymus dèl šių programų finansavimo ir universiteto struktūros pertvarkos, reikalingos toms programoms igyvendinti, vertina atliktų tyrimų rezultatus ir visos universiteto mokslo bei meno veiklos kokybę ir lygi;

2) nustato studiju tvarką;

3) tvirtina vidinę studijų kokybės užtikrinimo sistemą ir tikrina, kaip ji igyvendinama;

4) nustato dėstytojų ir mokslo darbuotojų pareigybių kvalifikacinius reikalavimus, tvirtina dėstytojų ir mokslo darbuotoju atestavimo ir konkursu eiti pareigas organizavimo bei darbo apmokejjimo tvarką;

5) šaukia universiteto akademinès bendruomenès susirinkimus (konferencijas) svarbiems universiteto veiklos klausimams aptarti; 
6) padalinio tarybai pasiūlius, jvertindamas asmens mokslinès ar pedagoginès ir (arba) kitos visuomenei svarbios veiklos rezultatus, teikia pedagoginius, garbès ir kitus vardus;

7) svarsto ir teikia siūlymus tarybai dèl universiteto vizijos ir misijos, strateginio veiklos, plètros planų;

8) svarsto ir teikia siūlymus tarybai dèl universiteto statuto pakeitimų;

9) svarsto ir teikia siūlymus tarybai dèl kandidatų tinkamumo eiti rektoriaus pareigas;

10) svarsto ir teikia siūlymus tarybai dèl universiteto reorganizavimo arba likvidavimo planų;

11) svarsto ir teikia siūlymus tarybai dèl universiteto lèšų (taip pat lèšų, skirtų administracijos ir kitų darbuotojų darbo užmokesčiui) ir nuosavybès teise valdomo turto valdymo, naudojimo ir disponavimo jais tvarkos;

12) svarsto ir teikia siūlymus tarybai dèl bendro studijų vietų skaičiaus nustatymo, atsižvelgiant i galimybes užtikrinti studijų ir mokslo, meno veiklos kokybę;

13) atlieka kitas teisès aktuose ir šiame statute nustatytas funkcijas.

Pagal VGTU statutą Senato nariais gali būti universiteto akademinès bendruomenès nariai, universiteto administracijos nariai, patenkantys i Senatą pagal pareigas, taip pat kitų mokslo ir studijų instituciju mokslininkai, dėstytojai ir pripažinti menininkai. Studentu skiriami atstovai turi sudaryti ne mažiau kaip 20 proc. Senato narių. Studentų atstovus i Senatą skiria studentų atstovybė, o jeigu jos nèra, visuotinè studentų konferencija. Profesoriaus ir vyriausiojo mokslo darbuotojo pareigas einantys asmenys turi sudaryti ne mažiau kaip 30 proc. Senato narių. Docento ir vyresniojo mokslo darbuotojo pareigas einantys asmenys turi sudaryti ne mažiau kaip 30 proc. Senato narių. Pagal pareigas i Senatą patekti gali ne daugiau kaip 10 proc. Senato narių, tarp ju gali būti ir kitų mokslo bei studijų institucijų darbuotojai. Universiteto rektorius yra Senato narys pagal pareigas.

Šiuo metu VGTU Senato sudaro 55 nariai. Pagal pareigas universiteto Senato nariais yra rektorius, keturi prorektoriai ir kancleris. Dvidešimt keturi Senato nariai atstovauja fakultetams arba jiems prilygintiniems padaliniams. Mokslo institutams ir kitiems mokslo padaliniams Senate atstovauja dvylika nariu, studentams trylika nariu. Tokiu būdu Senate turime 40 proc. profesorių, 36 proc. docentų ir vyresniuju mokslo darbuotoju bei 24 proc. studentų atstovų.

2014 m. truputi keitėsi Senato narių personalinė sudètis. Vietoje buvusio Senato nario doc. dr. Egidijaus Petraičio jungtinis mokslo padalinys Senato nariu išrinko Kelių tyrimo instituto direktorių doc. dr. Audrių Vaitkų, o Studentų atstovybe delegavo i Senatą tris naujus narius: Aistę Rimkutę, Justą Petrošių ir Laimoną Jonušką.

Senate sèkmingai veikia penkios nuolatinès komisijos (1.1 pav.).

Kiekvienas Senato narys (išskyrus rektorių ir Senato pirmininką) priklauso ne mažiau kaip vienai iš šių komisiju. Komisiju pirmininkai, kartu su Senato pirmininku ir jo pavaduotoju sudaro kolegiją. Senato ir kolegijos veikla vykdoma pagal patvirtintą darbo reglamentą ir kasmetini posėdžiu planą.

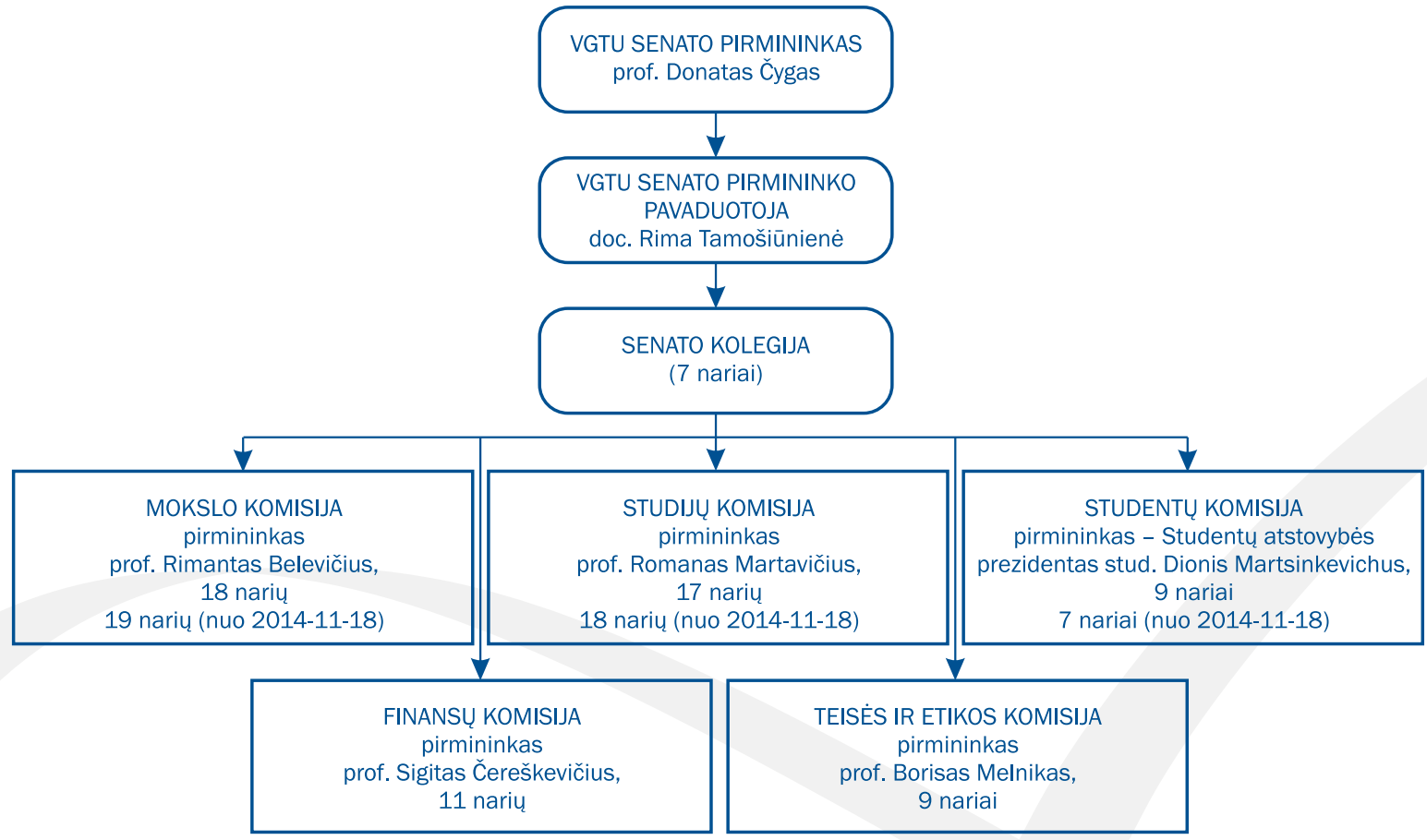

1.1 pav. VGTU Senato struktūra 
2014 m. VGTU Senatas svarstė daug svarbių universiteto gyvenimui klausimų: kokybės vadybos sistemos diegimą, metinę universiteto veiklos ataskaitą, $2013 \mathrm{~m}$. biudžeto ivykdymo ataskaitą ir $2014 \mathrm{~m}$. biudžeto projektą. Senatas aptarè universiteto išorinio vertinimo rezultatus, patvirtino naują, daug diskusiju sukèlusi universiteto dėstytojų, mokslo darbuotojų ir kitų tyrèjų darbo apmokėjimo tvarkos aprašą, svarstè universiteto strategijos igyvendinimą studiju procese, aptarè $2014 \mathrm{~m}$. bendrojo prièmimo rezultatus, tęstinio mokymo perspektyvas.

Be pagrindinių Senato darbo plane numatytų klausimų, buvo nagrinèjami ir bendrieji universitetui aktualūs klausimai.

2014 m. VGTU Senatas rektoriaus emerito vardus suteikè buvusiems universiteto rektoriams prof. habil. dr. Edmundui Kazimierui Zavadskui ir prof. habil. dr. Romualdui Ginevičiui. Profesoriaus emerito vardas suteiktas prof. habil. dr. Jonui Stankūnui, garbės daktaro vardas - Ohajo valstybinio universiteto (JAV) profesoriui Hojjat Adeli. 2014 m. Senatas suteikè keturis profesoriaus ir dvidešimt šešis docento pedagoginius vardus.

\section{Rektoratas}

Patariamają rektoriaus instituciją - rektoratą - sudaro rektorius, prorektoriai, fakultetų dekanai, kai kurių administracijos padaliniu vadovai ir du studentų atstovai. Rektoriaus prof. Alfonso Daniūno perduotas funkcijas atlieka studiju prorektorius prof. Romualdas Kliukas, mokslo prorektorius prof. Antanas Čenys, tarptautinių ryšių prorektorè doc. Asta Radzevičienè, plètros prorektorius prof. Alfredas Laurinavičius ir kancleris doc. Arūnas Komka.

\section{Struktūra}

\section{FAKULTETAI IR JIEMS PRILYGINTI PADALINAI, KATEDROS, CENTRAI, LABORATORIJOS}

\section{Aplinkos inžinerijos fakultetas}

Aplinkos apsaugos katedra

Geodezijos ir kadastro katedra

Keliu katedra

Miestu statybos katedra

Pastatų energetikos katedra

Vandentvarkos inžinerijos katedra

Aplinkos apsaugos institutas

Geodezijos institutas

Keliu tyrimo institutas

Teritoriju planavimo mokslo institutas

\section{Architektūros fakultetas}

Architektūros katedra

Architektūros pagrindų ir teorijos katedra

Dailès katedra

Dizaino katedra

Urbanistikos katedra

Architektūros institutas

Meninio ugdymo centras

Jaunojo architekto mokykla

Maketų ir kompiuterijos mokomoji studija

\section{Elektronikos fakultetas}

Automatikos katedra

Elektrotechnikos katedra

Elektroninių sistemų katedra

Kompiuterių inžinerijos katedra
Telekomunikacijų inžinerijos katedra

Telekomunikaciju mokslo institutas

Kompiuterijos mokomoji laboratorija

Stiprių magnetinių laukų institutas

\section{Fundamentinių mokslų fakultetas}

Chemijos ir bioinžinerijos katedra

Fizikos katedra

Spinduliuotès mokslinių tyrimų laboratorija

Grafinių sistemų katedra

Informaciniu sistemų katedra

Informacinių technologijų katedra

Inžinerinès grafikos katedra

Matematinès statistikos katedra

Matematinio modeliavimo katedra

Medžiagu atsparumo ir teorinès

mechanikos katedra

Taikomosios informatikos institutas

Informaciniu sistemų mokslo laboratorija

Lygiagrečiujų skaičiavimų laboratorija

Informacinių technologijų saugos

mokslo laboratorija

Mobiliujų aplikacijų laboratorija

\section{Kūrybinių industrijų fakultetas}

Filosofijos ir komunikacijos katedra

Kūno kultūros katedra

Kūrybinių technologijų katedra 
Kūrybos verslo ir komunikacijos katedra

Kūrybinių inovacijų laboratorija

Lietuvių kalbos katedra

Užsienio kalbų katedra

Estetinio ugdymo centras

Sporto ir turizmo klubas „Inžinerija“

\section{Mechanikos fakultetas}

Biomechanikos katedra

Mechanikos inžinerijos katedra

Mechatronikos ir robotikos katedra

Medžiagotyros ir suvirinimo katedra

Suvirinimo tyrimų ir diagnostikos mokslo

laboratorija

Poligrafinių mašinų katedra

Mechanikos mokslo institutas

Techninès kūrybos ir inovacijų centras

\section{Statybos fakultetas}

Architektūros inžinerijos katedra

Darbo ir gaisrinès saugos katedra

Gelžbetoninių ir mūrinių konstrukcijų katedra

Geotechnikos katedra

Metalinių ir medinių konstrukcijų katedra

Statybinès mechanikos katedra

Statybinių medžiagų katedra

Statybos ekonomikos ir nekilnojamojo turto

vadybos katedra

Statybos technologijos ir vadybos katedra

Taikomuju statinių, konstrukcijų ir medžiagu

laboratorija

Tiltų ir specialiujų statinių katedra

Statiniu konstrukcijų mokslo institutas

Inovatyvių statybinių konstrukciju

mokslo laboratorija

Geotechnikos mokslo laboratorija

Išmaniujų pastatų technologijų mokslo

institutas

Pažangių statybos technologijų ir vadybos

mokslo laboratorija

Statybinių medžiagų ir gaminio mokslo

institutas

Betono technologijų mokslo laboratorija Kompozitinių statybinių konstrukcijų mokslo laboratorija „Kompozitas“

Irangos ir bandinių laboratorija

\section{Transporto inžinerijos fakultetas}

Automobilių transporto katedra

Saugaus eismo laboratorija

Geležinkelių transporto katedra

Transporto technologiniu ìrenginių katedra

Transporto vadybos katedra
Intermodalinio transporto ir logistikos

kompetencijos centras

Transporto institutas

\section{Verslo vadybos fakultetas}

Finansų inžinerijos katedra

Imonių ekonomikos ir vadybos katedra

Socialinès ekonomikos ir vadybos katedra

Tarptautinès ekonomikos ir vadybos katedra

Teisès katedra

Verslo technologijų katedra

Tarptautinių studijų centras

\section{UNIVERSITETINIAI \\ MOKSLO PADALINIAI}

Civilinès inžinerijos mokslo centras

Termoizoliacijos mokslo institutas

Statiniu skaitmeninio ir informacinio

modeliavimo technologijų centras

\section{APTARNAVIMO IR ADMINISTRACIJOS PADALINIAI}

Apsaugos tarnyba

Archyvas

Biblioteka

Centrinè administracija

Darbuotoju saugos ir sveikatos skyrius

Finansų direkcija

Informacinių technologijų ir sistemų centras Integracijos ir karjeros direkcija

Kapitalinès statybos direkcija

Knygynas „Technika“

Leidykla „Technika“

Mokslo direkcija

Nuotoliniu studiju centras

Personalo direkcija

Plètros projektu skyrius

Raštinè

Sekretoriatas

Stojančiujų prièmimo ir informavimo centras Strateginio planavimo, kokybės vadybos ir analizès centras

Studijų direkcija

Teisès direkcija

Ūkio direkcija

Užsienio ryšių direkcija

Vaizdo ir garso techninių priemonių laboratorija

Vidaus audito skyrius

Viešosios komunikacijos direkcija

Viešujų pirkimų skyrius

Žinių ir technologiju perdavimo centras 



\section{Strateginiai universiteto prioritetai}
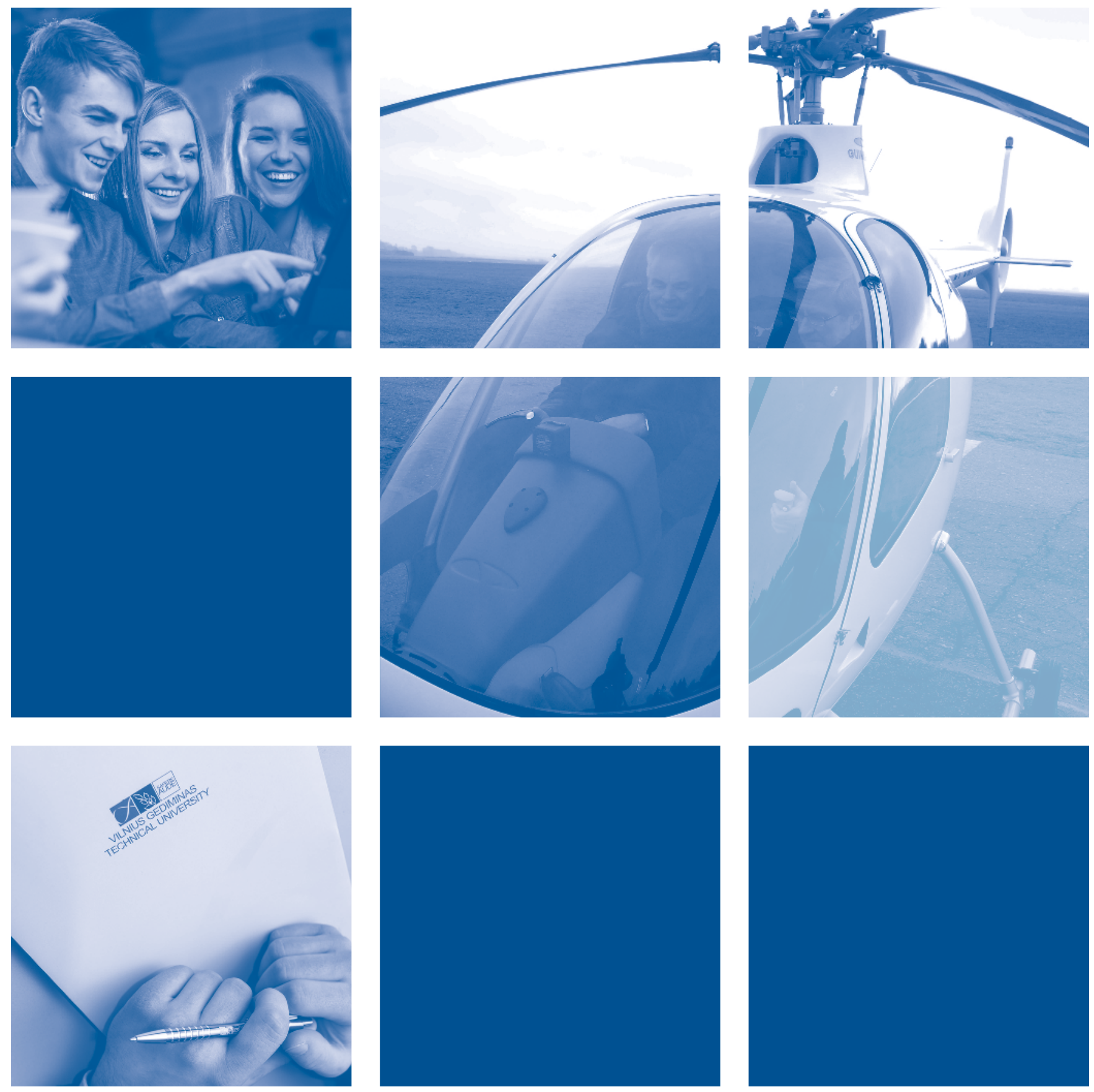



\section{Strateginiai universiteto prioritetai}

Pagrindinis strateginius Vilniaus Gedimino technikos universiteto veiklos prioritetus iki 2020 m. apibrèžiantis dokumentas yra 2014-2020 metų VGTU plètros strategija, patvirtinta Vilniaus Gedimino technikos universiteto Tarybos 2013 m. birželio 25 d. nutarimu Nr. 3-1. Pagrindinès strategijoje itvirtintos veiklos plètojimo kryptys yra kvalifikuotu, mokslo ir darbo rinkose konkurencingu specialistų rengimas; mokslinès veiklos koncentravimas ir tarptautinio lygio mokslinių tyrimų vykdymas siekiant lyderystės Baltijos šalyse pagal prioritetines kryptis, inovaciju plètra prisidedant prie darnaus šalies ir regiono vystymosi. VGTU plètros strategijos tikslai ir uždaviniai pateikti 2.1 lentelèje.

2.1 lentelè. VGTU plètros strategijos tikslai ir uždaviniai

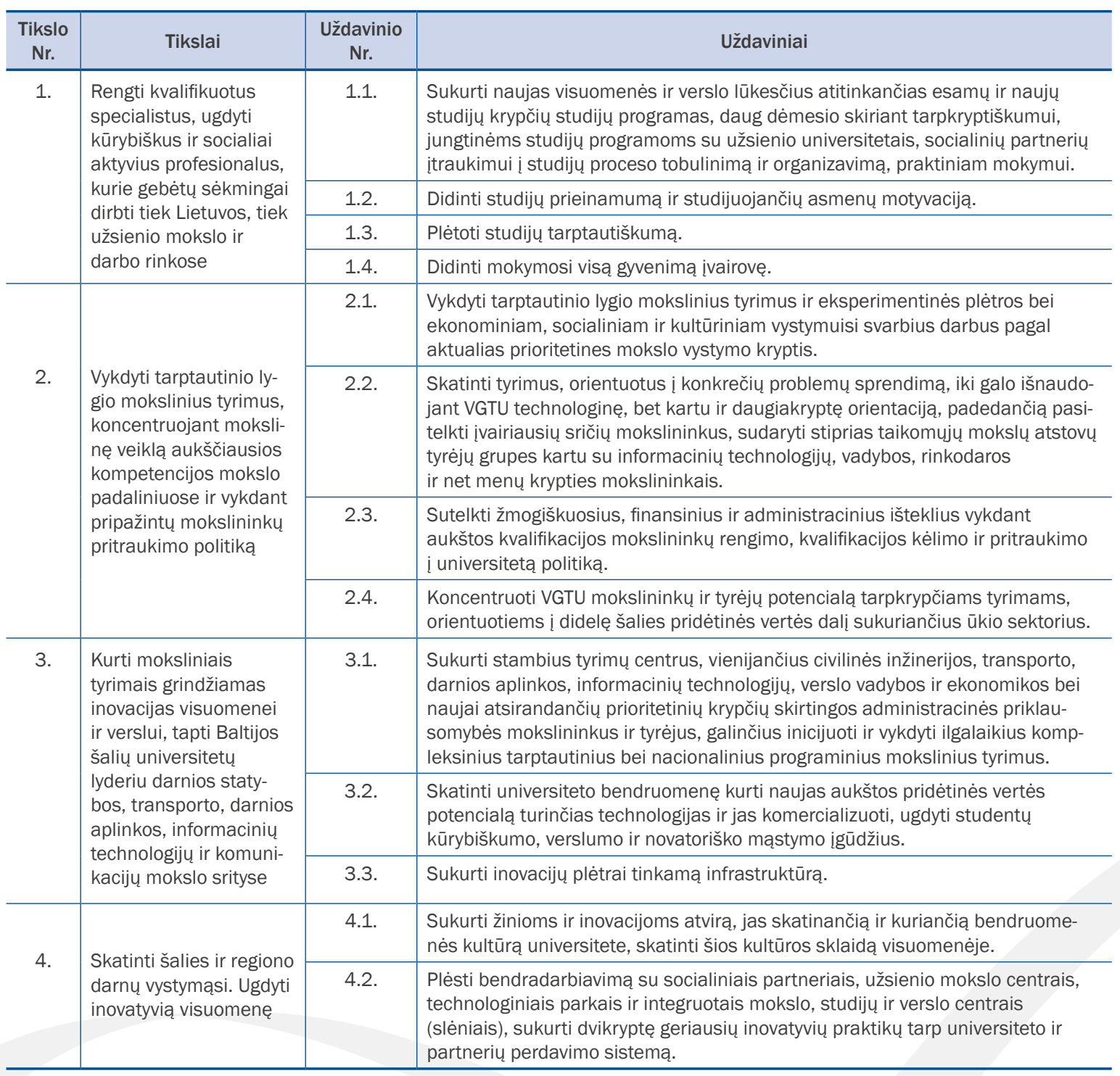

Siekiant igyvendinti užsibrèžtus universiteto tikslus, plètros strategija taip pat turi horizontalų prioritetą tobulinti universiteto valdymą ir plètoti infrastruktūrą. Universiteto plètros strategijos igyvendinimo pažangai vertinti patvirtintas stebėsenos rodiklių sąrašas, kuris kiekvienais metais peržiūrimas ir tikslinamas.

Vilniaus Gedimino technikos universitetas puikiai suvokia, kad iškelti ambicingi tikslai negali būti igyvendinti pagal visas kryptis, todèl lyderystès tarp Baltijos šalių universitetų siekiama mokslinè veikla koncentruojama pagal patvirtintas VGTU prioritetines mokslinių tyrimų kryptis ir tematikas. 



\section{Studijos ir mokymasis visą gyvenimą}
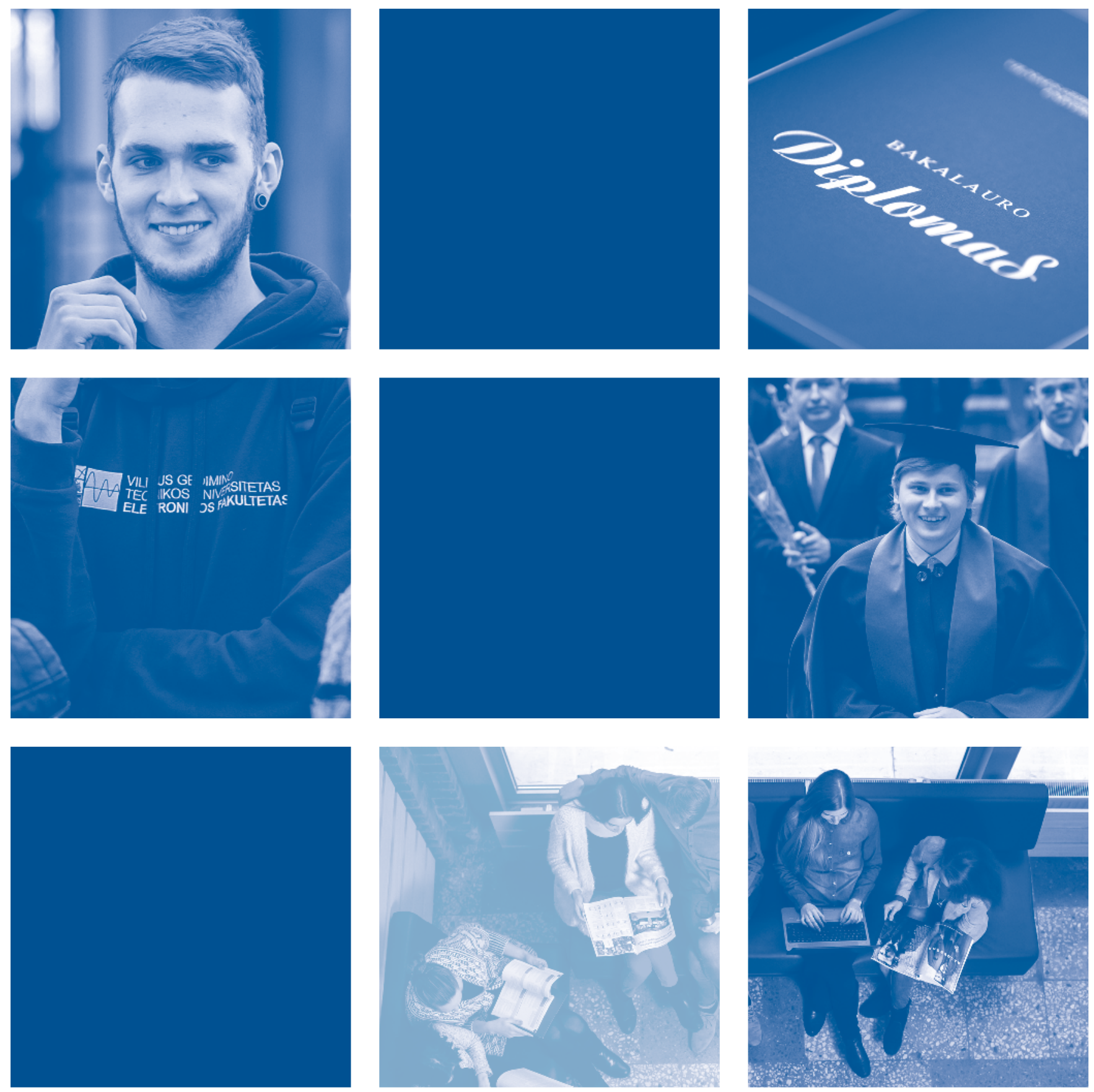



\section{Studijos ir mokymasis visą gyvenimą}

\subsection{Studijų prioritetai ir plètra $2014 \mathrm{~m}$.}

Prioritetinis Vilniaus Gedimino technikos universiteto tikslas - ugdyti kūrybiškus aukštos kvalifikacijos specialistus. Universitetas lyderiauja technologijos mokslų srityje ir užtikrina šiuolaikines, i darbo rinką orientuotas studijas.

Atsižvelgdamas i pasaulines tendencijas universitetas nuolat tobulina studijų programas ir taip užtikrina mūsų absolventų paklausą darbo rinkoje. Lyderiaudamas pagal studentų mainus su užsienio universitetais, VGTU studentams suteikia galimybę plėsti igytas žinias ir patirti, dali studijų laiko studijuojant ES ir kitu šalių universitetuose. Siūlydamas šias galimybes universitetas siekia, kad studentai, studijų metais skatinami akademinès aplinkos, siektų tapti pažangiais specialistais, kurių idèjos, kūrybingumas ir gabumai užtikrintų inovaciju ir technologiju plètrą kasdieniame gyvenime bei moksle.

VGTU ivvertinimas pasauliniame kontekste irodo, kad tai europietiškas universitetas, savo prioritetais ir plètra atitinkantis visus šiuolaikiniam universitetui būdingus bruožus. Todèl VGTU studiju prioritetai ir plètra 2014 m. buvo nukreipti į:

- studiju programų kokybès priežiūrą aktyviai dalyvaujant darbdaviams;

- jungtinių studijų programų su užsienio universitetais kūrimą;

- studiju prieinamumo visų socialinių sluoksnių atstovams didinimą;

- papildomų ir išlyginamuju studijų kolegiju absolventams plètrą;

- bakalauro ir magistro studijas anglu kalba;

- tarptautinius vieno semestro studentų ir dėstytojų mainus;

- mokomujų, gamybinių ir mokslinių praktikų pažangiausiose šalies ir užsienio įmonėse plètojimą;

- bibliotekos, mokomujų el. knygų leidybos gausinimą;

- mokymosi visą gyvenimą sistemos plètrą;

- studiju programų atnaujinimą ir tobulinimą orientuojantis i tarptautiškumą ir išorès poreikius, derinant ilgalaikiu žinių ir gebėjimų formavimą su praktiniais rinkos poreikiais;

- studiju universitete pristatymo visuomenei ir bendradarbiavimo su vidurinių mokyklų bendruomenėmis formų plètrą.

Šios ir kitos priemonès sudarè prielaidą Vilniaus Gedimino technikos universitetui būti tarp geriausių, kokybiškas studijas organizuojančių pasaulio universitetų.

\subsection{Studijų sistema}

Vilniaus Gedimino technikos universitete rengiami bakalaurai, magistrai, mokslo daktarai.

Pirmosios pakopos (bakalauro) studijos - tai studijos, kurių programos orientuotos i universaluji bendraji universitetini išsilavinimą, teorini pasirengimą ir aukščiausio lygio profesinius gebèjimus. Baigus universitetines pirmosios pakopos studijas, igyjamas bakalauro kvalifikacinis laipsnis.

Pirmosios pakopos studijos yra 240 kreditų apimties. Sèkmingai baigus studijas igyjama teisè tęsti mokslus magistrantūroje.

Antrosios pakopos studijos - tai universitetinès studijos, skiriamos pasirengti savarankiškam mokslo (meno) darbui arba kitam darbui, kuriam atlikti reikia mokslo žinių ir analitinių gebėjimų. Baigus magistrantūros studijas, igyjamas kvalifikacinis magistro laipsnis. Magistrantūros studiju apimtis - 90-120 kreditų.

Vientisosios studijos - tai tęstinumu susiejamos pirmosios ir antrosios pakopu universitetinès studijos. Studijų trukmé - 5 metai, studijų apimtis - 300 kreditų. Baigus vientisąsias studijas suteikiamas kvalifikacinis magistro laipsnis.

Trečiosios pakopos (doktorantūros) studijos - tai universitetinės mokslininkų rengimo studijos. I jas priimami asmenys, turintys kvalifikacini magistro laipsni arba vienpakopės studijų sistemos aukštojo mokslo diplomą. 
Išlyginamosios studijos - tai pirmosios pakopos universitetinès studijos, skirtos kolegijų absolventams, baigusiems to profilio studijų programas, turintiems aukštaji neuniversitetinị išsilavinimą, igijusiems profesinę kvalifikaciją arba profesinio bakalauro laipsni ir norintiems igyti universitetini išsilavinimą. Studijų apimtis 120 kreditų. Asmenys, baigę išlyginamąsias studijas, bendraja tvarka gali dalyvauti konkurse stoti ji atitinkamos studijų krypties magistrantūrą.

Papildomosios studijos - tai studijos, apimančios pirmosios pakopos studijų dalykus, kurių nèra studijavę pretendentai, stojantys i magistrantūrą. Šie dalykai būtini tam, kad studentai turètų žinių ir gebejjimu, reikalingu sėkmingoms atitinkamos krypties magistrantūros studijoms. Papildomosios studijos skirtos asmenims, baigusiems kitos krypties universitetines studijas ir turintiems bakalauro laipsni arba baigusiems kolegijas ir igijusiems profesinio bakalauro laipsnį. Papildomuju studijų apimtis - 30-90 kreditų. Baigus studijas išduodamas baigtas studijas liudijantis pažymèjimas.

Dalinès studijos - tai studijos asmenims, siekiantiems igyti atitinkamų žinių ir gebejjimu studijuojant tam tikrą programos dali ar atskirus studijų dalykus. Suteiktos žinios bei gebėjimai ịvertinami ir patvirtinami pažymèjimu.

Profesinės kvalifikacijos tobulinimo studijos - tai studijos asmenims, turintiems ne žemesni kaip vidurini išsilavinimą arba baigusiems pirmosios ar antrosios pakopos studijas ir norintiems siekti aukštesnès profesinès kvalifikacijos.

Studiju organizavimo tvarką Vilniaus Gedimino technikos universitete reglamentuoja Mokslo ir studijų istatymas, Lietuvos Respublikos Vyriausybès teisès aktai ir VGTU norminiai aktai.

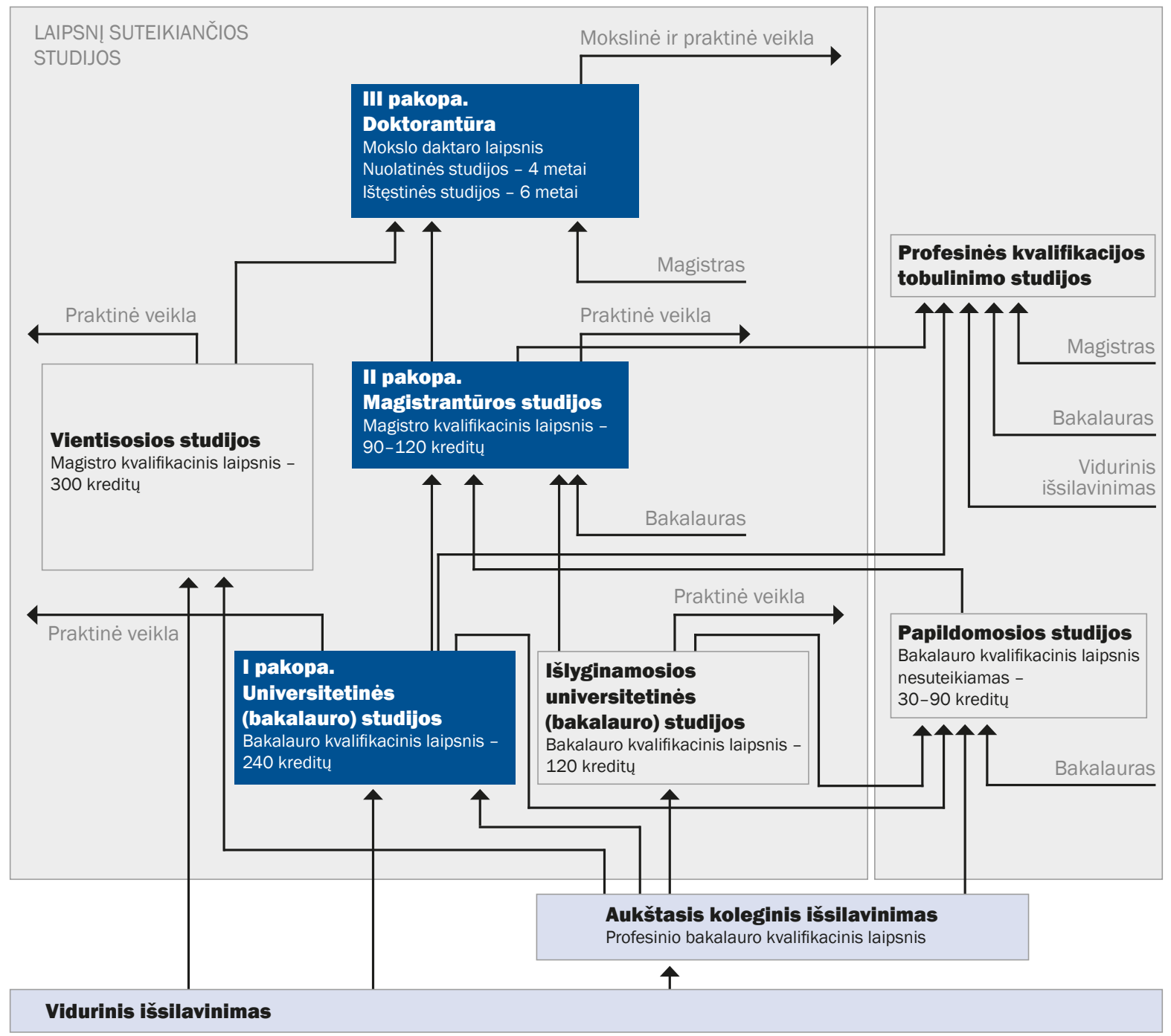

3.1 pav. Vilniaus Gedimino technikos universiteto studijų modelis 


\subsection{Studijų programos}

Studijų programų skaičiaus pasiskirstymas pagal pakopas 2010-2014 m. pateiktas 3.2 pav.

VGTU 2014 m. parengta, vertinta ir akredituota bei i Studiju, mokymo programu ir kvalifikacijų registrą itraukta 12 naujų studijų programų, kurios sėkmingai prisidės prie mokslo ir pažangos vystymo tiek Lietuvoje, tiek Europos Sajungos erdvèje:

- naujos pirmosios pakopos studijų programos:

aeronautikos inžinerijos studijų krypties - avionika;

gamybos inžinerijos studijų krypties - kokybės inžinerija;

statybos technologijos studiju krypties - pastatų inžinerinis valdymas;

programų sistemos studijų krypties - programų inžinerija;

finansų studijų krypties - finansų inžinerija;

verslo studiju krypties - verslo logistika;

- naujos antrosios pakopos studijų programos:

statybos inžinerijos studiju krypties - architektūros inžinerija, inovatyvi kelių ir tiltų inžinerija;

bendrosios inžinerijos studiju krypties - inovatyvūs sprendimai geomatikoje;

gamybos inžinerijos studijų krypties - mechatroninès sistemos, mechatronika;

vadybos studijų krypties - statinių ir jų aplinkos darni plètra.

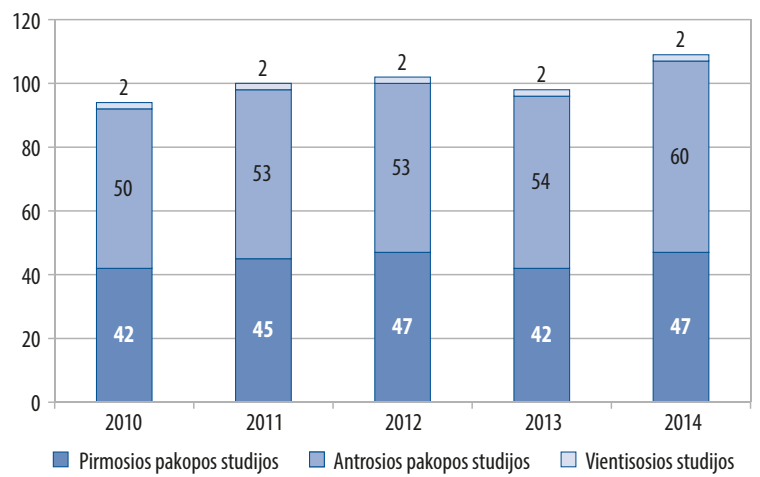

3.2 pav. Studijų programu skaičiaus pasiskirstymas pagal pakopas

Parengtos ir akredituotos net keturios naujos jungtinės antrosios pakopos studijų programos: mechatronika (vykdoma su Vokietijos Braunšveigo technikos universitetu), inovatyvūs sprendimai geomatikoje, inovatyvi kelių ir tiltų inžinerija (vykdomos su Rygos technikos universitetu), statinių ir jų aplinkos darni plètra (vykdoma su Maskvos valstybiniu M. V. Lomonosovo universitetu).

Labai svarbus studijų programų kokybės rodiklis - išorinis studijų programų vertinimas ir ju akreditacija. Teigiamas studijų programų ịvertinimas yra sėkmingo dėstytojų ir administracijos padalinių darbo rezultatas. Nuoseklus jų atnaujinimas, naujų studijų dalykų įtraukimas, nauju dėstymo metodų taikymas leido pasiekti gerų rezultatų.

2014 m. po išorinio vertinimo buvo akredituota 19 studijų programų:

- aštuonios pirmosios pakopos - taikomoji statistika ir ekonometrija; verslo informacinès sistemos; inovatyvioji gamybos inžinerija; inžinerinè informatika; informacinių technologiju paslaugu valdymas; statybos inžinerija; multimedija ir kompiuterinis dizainas; bioinžinerija;

- vienuolika antrosios pakopos - nekilnojamojo turto vadyba; saulès elementų ir modulių inžinerija; kūrybos visuomenès komunikacija; inžinerinè informatika; ekonomikos inžinerija; statybos inžinerija; informacijos ir informacinių technologijų sauga; aplinkos apsaugos vadyba ir švarioji gamyba; elektronikos inžinerija; bioinžinerija; nanobiotechnologija.

Remiantis išorinio vertinimo išvadomis, septynios studijų programos akredituotos šešeriems metams. Studiju programa akredituojama šešeriems studiju metams, jei išorinio vertinimo išvadoje pateiktas studiju programos ivvertimas sudaro ne mažiau kaip aštuoniolika balų ir nė viena vertinama sritis nėra jivertinta „Nepatenkinamai“ ar „Patenkinamai“. Dvylika studiju programų akredituota trejiems metams. Tokiam laikotarpiui akredituojama studiju programa, jei išorinio vertinimo išvadoje pateiktas studijų programos ivertinimas sudaro ne mažiau kaip dvylika balų ir nè viena vertinama sritis nèra įvertinta „Nepatenkinamai“ t. y. 1 balu. Viena iš dažniausių ekspertų pastabų ir žemiausiai ịvertintos 2014 m. šios vertinimo sritys: programos tikslai ir numatomi studijų rezultatai, programos sandara, programos vadyba.

Naujų ir naujam laikotarpiui akredituotų studijų programų 2014 m. sąrašas pateiktas 3.1 lentelèje. 
3.1 lentelè. 2014 m. įregistruotos naujos ir akredituotos po išorinio vertinimo VGTU studijų programos

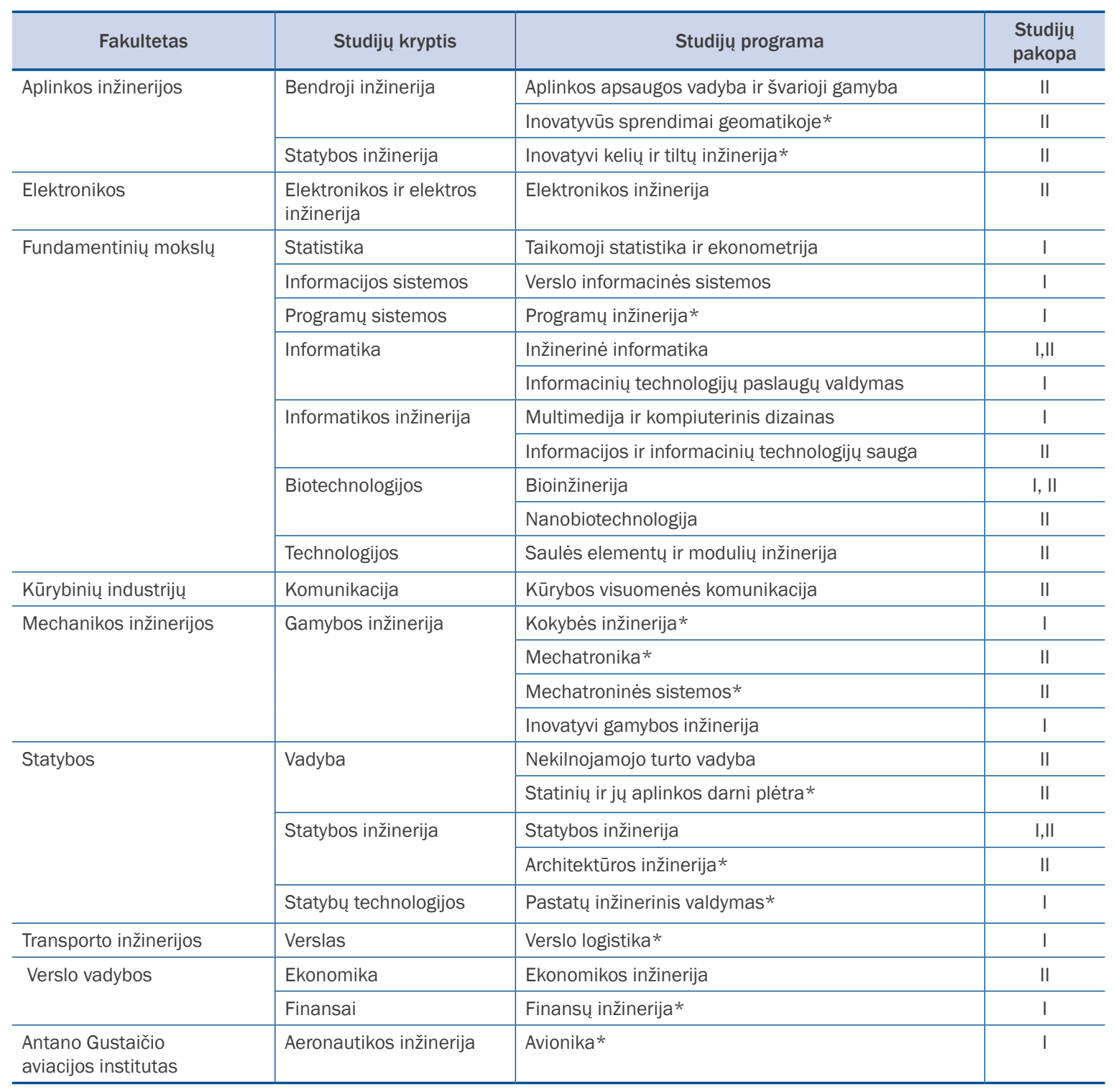

* Iregistruotos Studijų, mokymo ir kvalifikacijų registre naujos studiju programos

VGTU pirmosios, antrosios studiju pakopų ir vientisujų studijų $2014 \mathrm{~m}$. studentai galëjo savo studijoms pasirinkti programas iš 109 akredituotų universitetiniu studiju programų. $2014 \mathrm{~m}$. universitete buvo vykdomos 47 pirmosios pakopos studijų (3.2 lentelè), 60 antrosios pakopos studijų (3.3 lentelè) ir 2 vientisujų studiju programos (3.4 lentelè). 


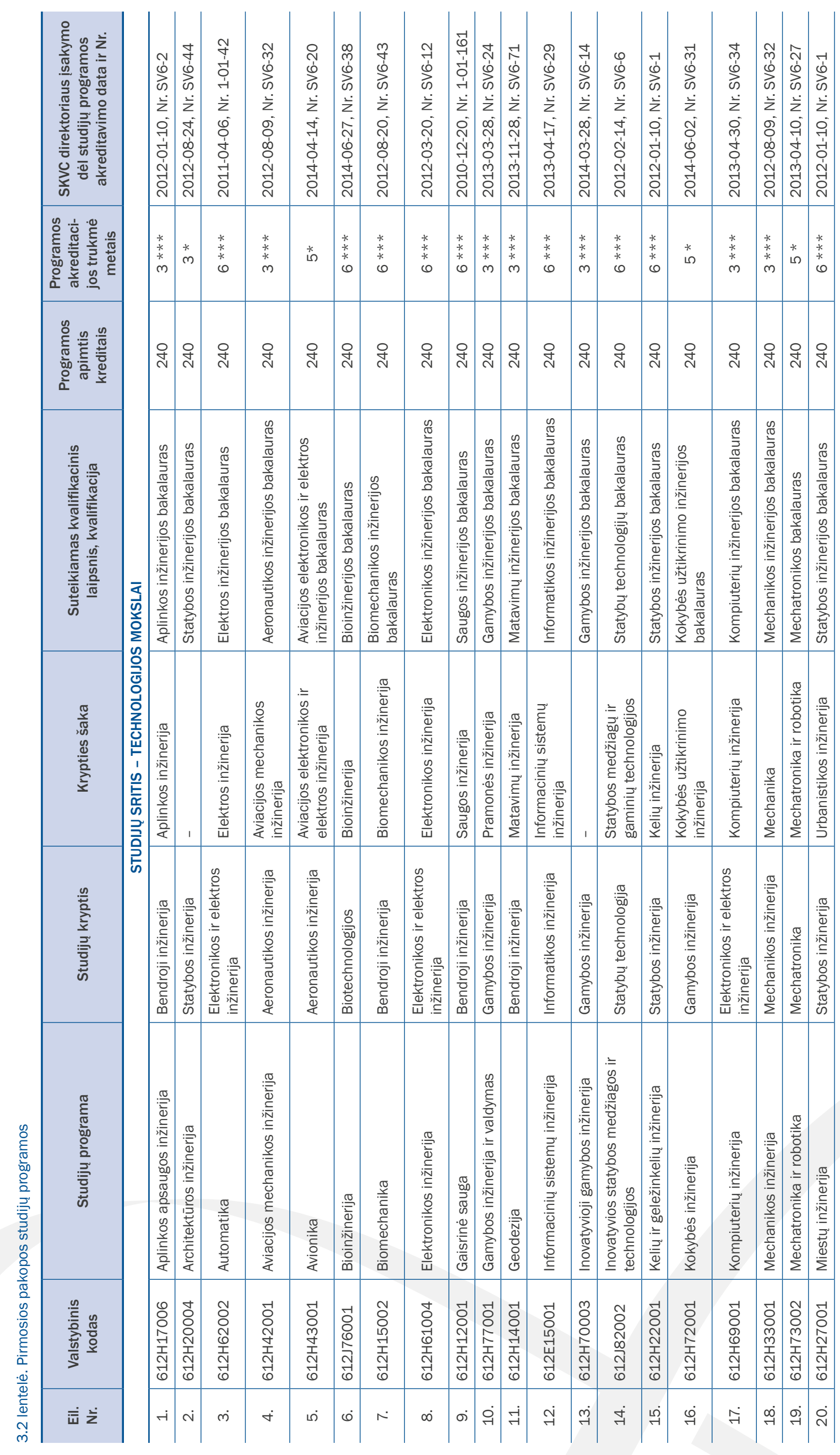




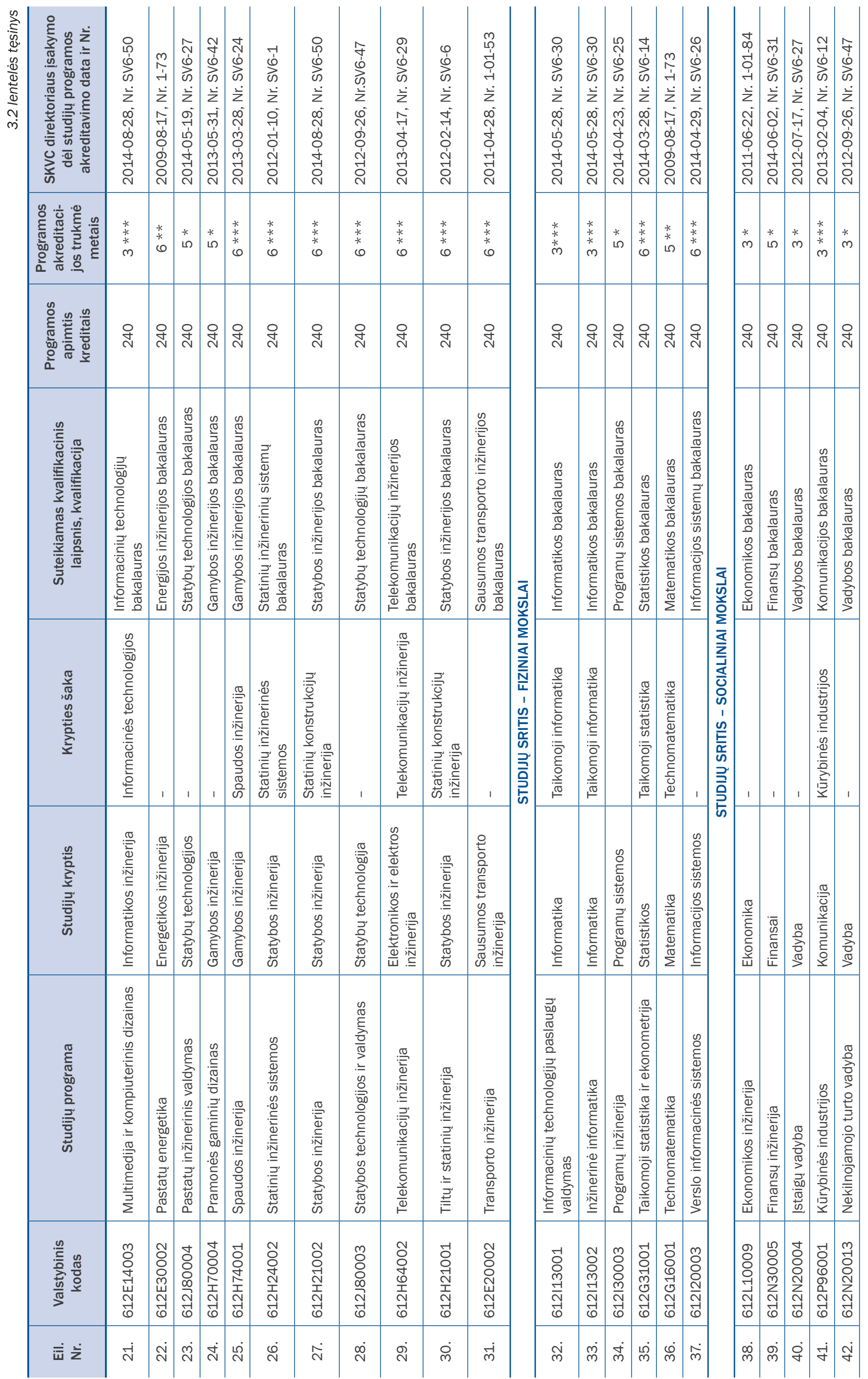




$$
\|
$$




\begin{tabular}{|c|c|c|c|c|c|c|c|c|c|c|c|c|c|c|c|c|c|c|c|c|c|c|c|c|c|}
\hline 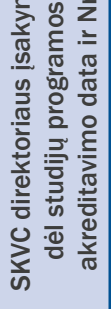 & & 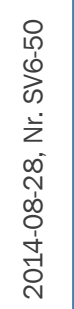 & 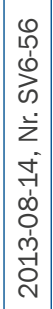 & 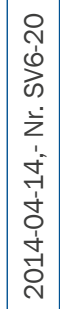 & 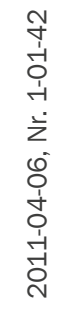 & 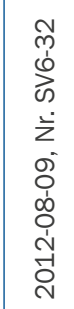 & 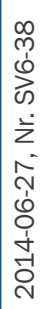 & 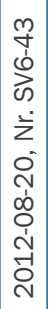 & 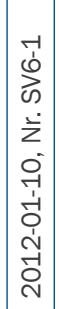 & 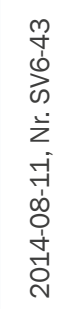 & 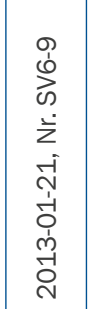 & 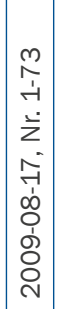 & 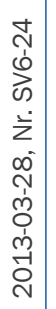 & 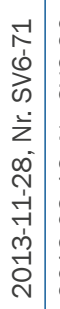 & 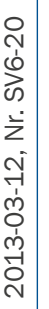 & 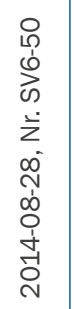 & 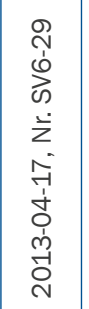 & 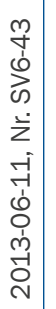 & 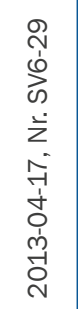 & 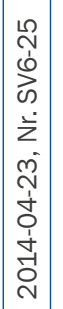 & $\begin{array}{l}\vec{m} \\
0 \\
0 \\
\text { के } \\
\dot{z} \\
0 \\
0 \\
0 \\
0 \\
0 \\
\dot{1} \\
\dot{1} \\
0\end{array}$ & 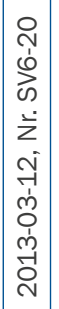 & 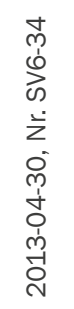 & 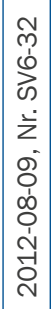 & เे \\
\hline 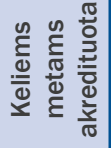 & & $\begin{array}{l}* \\
* \\
* \\
m\end{array}$ & \begin{tabular}{|l|l}
$*$ \\
$*$ \\
$*$ \\
0 \\
0
\end{tabular} & $\begin{array}{l}* \\
m\end{array}$ & $\begin{array}{l}* \\
* \\
* \\
* \\
0\end{array}$ & $\begin{array}{l}* \\
* \\
* \\
m \\
m\end{array}$ & $\begin{array}{l}* \\
* \\
* \\
0 \\
0\end{array}$ & $\mid \begin{array}{l}* \\
* \\
* \\
m \\
m\end{array}$ & \begin{tabular}{|l|}
$*$ \\
$*$ \\
$*$ \\
$*$ \\
0
\end{tabular} & $\begin{array}{l}* \\
* \\
* \\
* \\
0\end{array}$ & $\begin{array}{l}* \\
* \\
* \\
m\end{array}$ & \begin{tabular}{|l|}
$*$ \\
$*$ \\
0 \\
0
\end{tabular} & $\begin{array}{l}* \\
* \\
* \\
0\end{array}$ & $\begin{array}{l}* \\
* \\
* \\
m \\
m\end{array}$ & $\begin{array}{l}* \\
* \\
* \\
6\end{array}$ & $\begin{array}{l}* \\
* \\
* \\
0\end{array}$ & $\begin{array}{l}* \\
* \\
* \\
0 \\
0\end{array}$ & $\begin{array}{l}* \\
* \\
* \\
0\end{array}$ & $\begin{array}{l}* \\
* \\
* \\
0\end{array}$ & 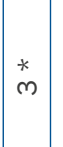 & $\stackrel{*}{m}$ & $\mid \begin{array}{l}* \\
* \\
* \\
0\end{array}$ & $\begin{array}{l}* \\
* \\
* \\
m\end{array}$ & 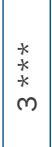 & * \\
\hline 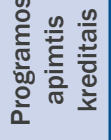 & & సิ & ণิ & ৪ & ণิ & ণิ & ঙ্ণি & 胥 & సิ & तิ & ্ָণি & సి & ণิ & 尺્નి & ণิ & సิ & ণิ & ঙิ & ণ্ & ৪ & ৪ & নิ & ণิ & สิ & สิ \\
\hline 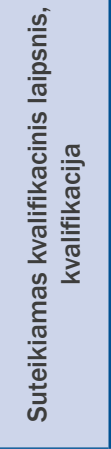 & 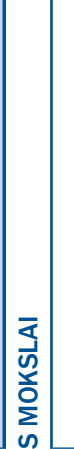 & 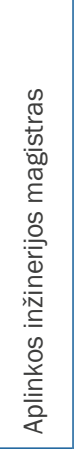 & 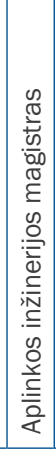 & 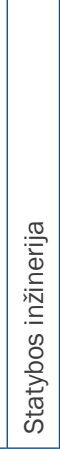 & 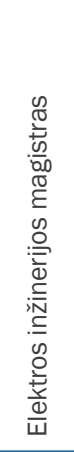 & 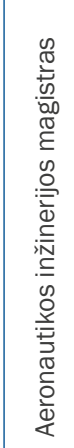 & 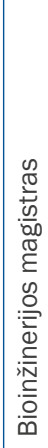 & 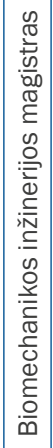 & 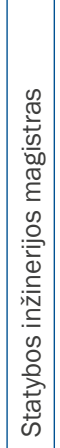 & 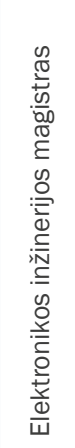 & 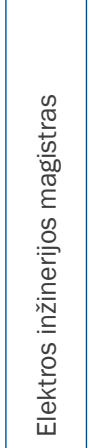 & 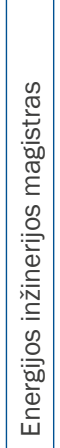 & 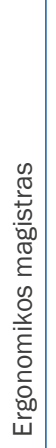 & 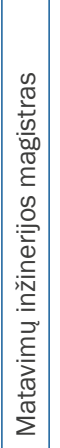 & 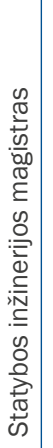 & 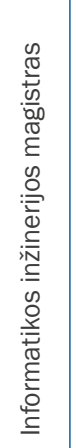 & 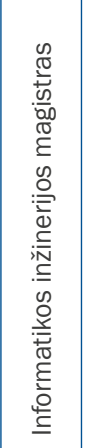 & 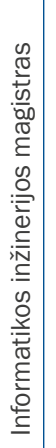 & 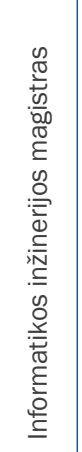 & 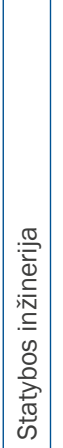 & 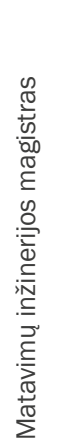 & 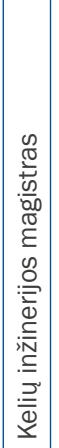 & 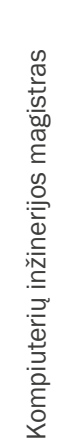 & 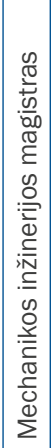 & 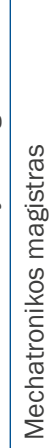 \\
\hline 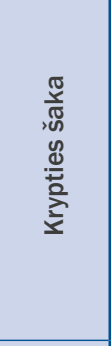 & 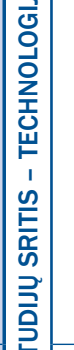 & 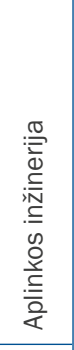 & 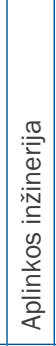 & & 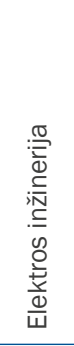 & 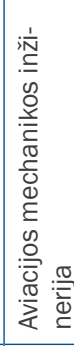 & 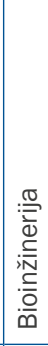 & 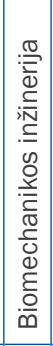 & & 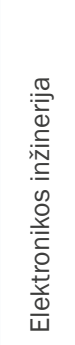 & 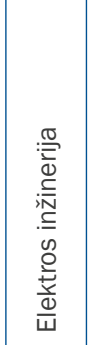 & & 1 & 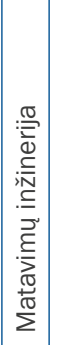 & 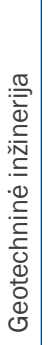 & 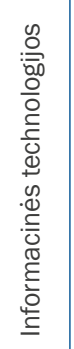 & 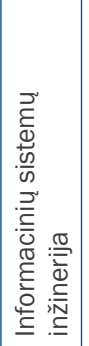 & 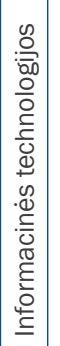 & 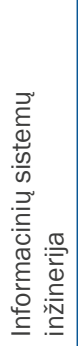 & & 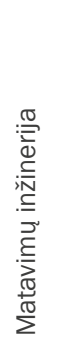 & 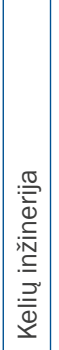 & 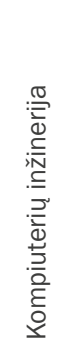 & 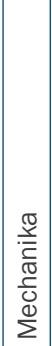 & 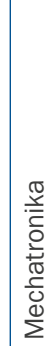 \\
\hline 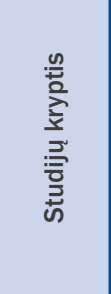 & & 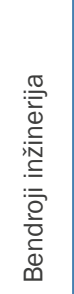 & 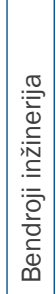 & 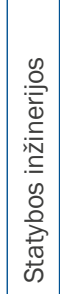 & 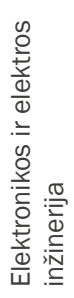 & 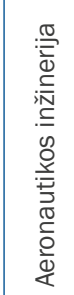 & 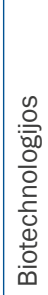 & 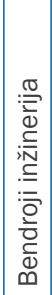 & 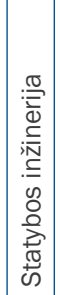 & 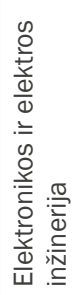 & 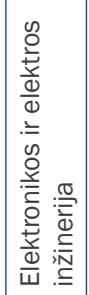 & 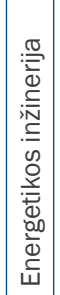 & -2 & 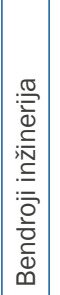 & 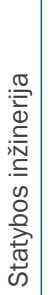 & 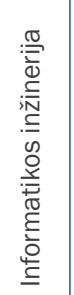 & 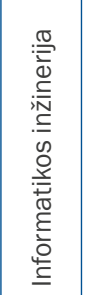 & 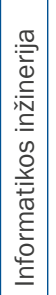 & 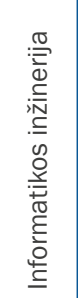 & 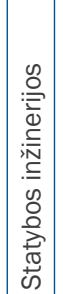 & 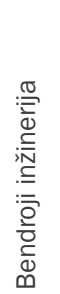 & 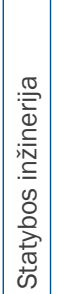 & 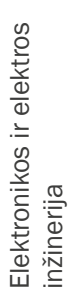 & 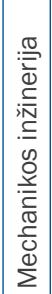 & 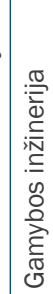 \\
\hline 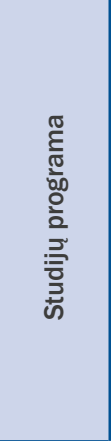 & & 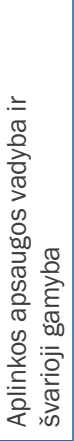 & 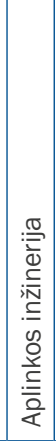 & 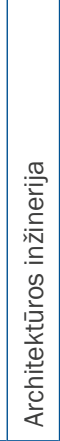 & 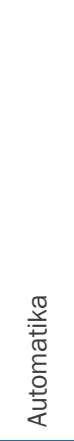 & 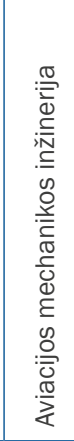 & : & 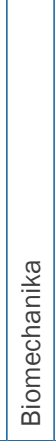 & 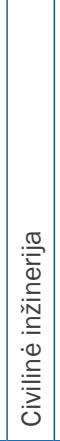 & 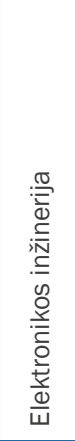 & 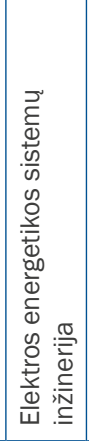 & 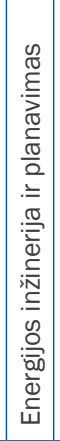 & ш & 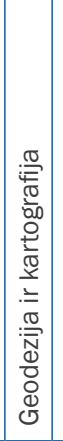 & 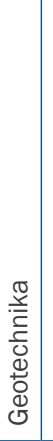 & 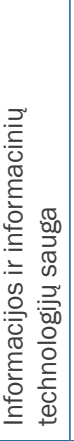 & 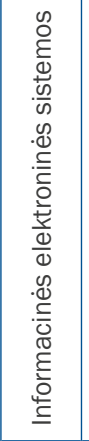 & 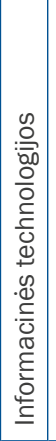 & 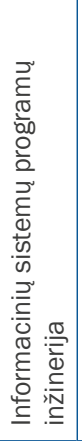 & 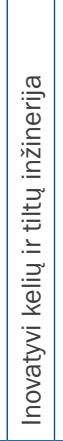 & 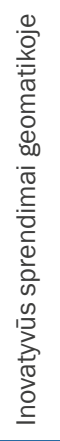 & 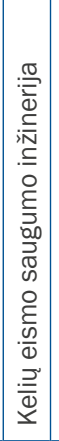 & 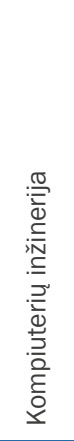 & 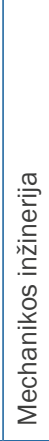 & $\overline{\frac{0}{0}}$ \\
\hline 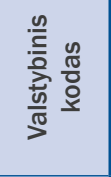 & & 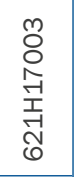 &  & $\begin{array}{l}\stackrel{2}{ } \\
0 \\
0 \\
\text { I } \\
\text {. } \\
0 \\
0\end{array}$ & 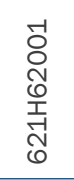 & 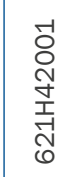 & $\begin{array}{l}-1 \\
8 \\
0\end{array}$ & 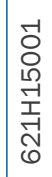 & 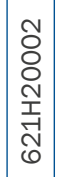 & 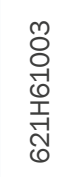 & 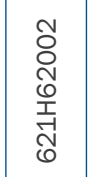 & $\begin{array}{l}m \\
\delta \\
o \\
\tilde{m} \\
\ddot{\sim} \\
0\end{array}$ & & 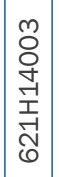 & ర్ & 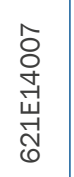 & 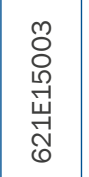 & 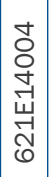 & 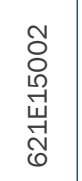 & $\begin{array}{l}-1 \\
8 \\
0 \\
0 \\
\mathbf{1} \\
00 \\
0 \\
0\end{array}$ & 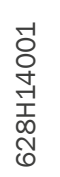 & 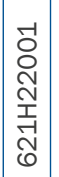 & \begin{tabular}{l}
-1 \\
8 \\
8 \\
0 \\
0 \\
\multirow{1}{7}{} \\
0
\end{tabular} & 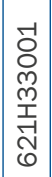 & 0 \\
\hline 立 & & - & ح & & $\dot{\nabla}$ & ம் & 6 & & $\infty$ & $\sigma^{\circ}$ & ने & تં & & +1 & $\underset{f}{+}$ & ம் & $\dot{\theta}$ & ᄀ & $\stackrel{\infty}{\sim}$ & $\mathrm{r}$ & $\stackrel{\sim}{N}$ & त் & ก่ & & \\
\hline
\end{tabular}




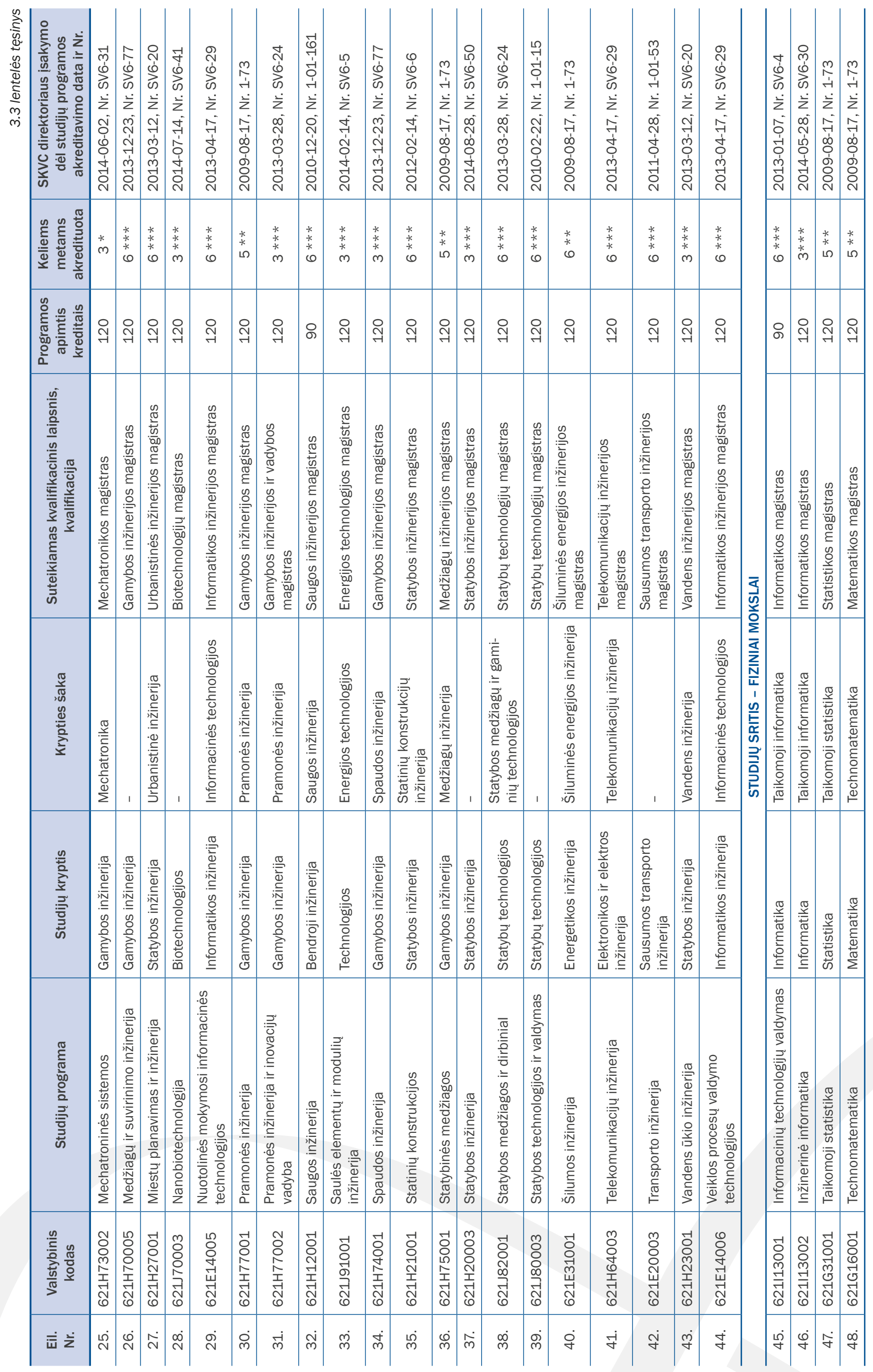




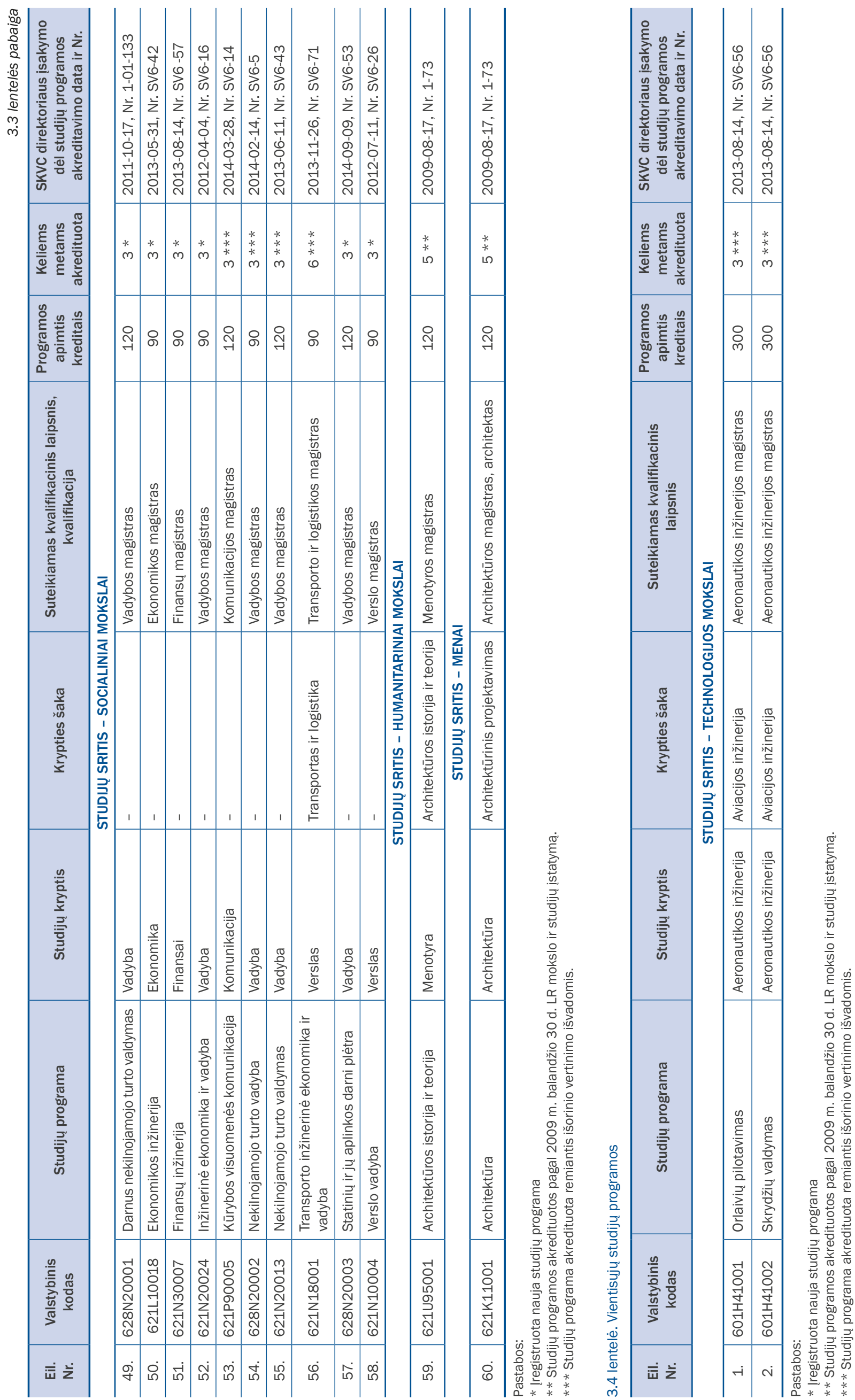




\subsection{Studijų organizavimas}

Studijos universitete organizuojamos pagal akredituotas studiju programas. Studijos planuojamos, organizuojamos ir vykdomos fakultetuose, katedrose. $2014 \mathrm{~m}$. toliau ypatingas dėmesys skirtas studiju programų kokybei, ištęstinių studijų, vykdomų nuotoliniu būdu, plètrai, praktinio studentų mokymo gerinimui ir tarptautiškumo (studijų anglų kalba) plètrai. Pradètos vykdyti dalinès studijos.

\section{Studijų Vilniaus Gedimino technikos universitete formos:}

- nuolatiné;

- ištęstinè.

Nuolatinès studijos. Teoriniai ir praktiniai dalykai dèstomi auditorijose ir laboratorijose dieną. Savarankiškam darbui skirtą laiką studentas planuoja pats taip, kad už ši darbą atsiskaitytų studijų programoje nurodytu laiku.

Ištęstinès studijos. Pirmą semestro mènesi šešias dienas vyksta į̌anginès paskaitos (8:30-21:30 val.), o vèliau - kartą arba du per mènesị, šeštadieniais (8:30-18:00 val.). Semestras baigiamas sesija, kurios trukmè - nuo 6 iki 14 dienų.

Studijos nuotoliniu būdu vyksta pagal sudarytą tvarkaraštị. Užsiėmimų skaičius nustatomas pagal programoje numatytą valandų skaičių, per visą semestrą išdèstoma tolygiai. Ne mažiau kaip 50 \% jų vyksta vaizdo konferencijų būdu. I juos pageidaujantys studentai gali atvykti ir bendrauti su déstytojais gyvai. Su dèstytoju galima bendrauti elektroniniu būdu (vaizdo konferencijos, elektroninis paštas, diskusiju kambariai), telefonu arba atvykti i universitetą konsultuotis dėstytojo budejjimo valandomis. Sesijos metu egzaminai laikomi VGTU patalpose. Iš anksto pranešus ir gavus fakulteto dekano leidimą, egzaminus galima laikyti ir nuotoliniu būdu.

Studiju programos igyvendinamos taikant inovatyvius dèstymo metodus: temines diskusijas, darbą grupèse, atvejų analizę, el. mokymąsi, studijas organizuojant nuotoliniu būdu ir kt.

Nuo 2014 m. pavasario semestro studentai, rinkdamiesi laisvai pasirenkamus dalykus, galëjo rinktis iš dar platesnio studijų dalykų sąrašo, kuris sudarytas ne vien iš studijų programose dėstomų studijų dalykų. Pvz., Architektūros fakultetas organizuoja kūrybines dirbtuves, kuriose užsiėmimus veda iš užsienio atvykę lektoriai; 2014 m. pritarta naujam užsienio kalbų dėstymo modeliui, kuri igyvendinant pirmajame semestre nustatomas pirmosios pakopos studentų anglų kalbos lygis ir studentai, surinkę mažiau nei 50 ivvertinimo balų, papildomai vieną semestrą mokomi anglų kalbos. Naujojo užsienio kalbų dėstymo modelio siekis - VGTU studentu profesinès specialybės anglų kalbos mokèjimas B2/C1 lygiu ir galimybės mokytis antrają užsienio kalbą (vokiečių, prancūzų kalbos) A1-A2, B1-B2 lygiais suteikimas. Vokiečių arba prancūzų kalbas studentai gali rinktis papildomai kaip laisvai pasirenkamus studijų dalykus.

Nuo 2014 m. rudens semestro prie Verslo vadybos fakulteto, kuriame antrosios pakopos studijų dalykai dèstomi ciklais, prisijungè ir Architektūros fakultetas. Šiame fakultete tokiu būdu studijuoti galima keletą pirmosios ir antrosios pakopos studijų dalykų. Toks užsièmimų organizavimo būdas padeda efektyviau įsisavinti studijų dalykų medžiagą, nuosekliau pasiekti numatomus studijų rezultatus.

\section{Informacinès studijų proceso valdymo technologijos}

VGTU veikia išsamus universiteto informacinės sistemos studiju posistemis. Jis apima studentų prièmimo, studentų studijų rezultatų, studentų paskolų, studijų įmokų sutarčių, studijų programų ir studijų dalykų, absolventų ir jų diplomų apskaitos, pedagoginio krūvio ir kitos su studijų organizavimu susijusios veiklos duomenų tvarkymą ir valdymą. Pagrindiniai studijų posistemio uždaviniai - patogus studijų programų ir studijų dalykų duomenų irašymas ir valdymas, jų viešinimas virtualioje erdveje, fakultetų, katedru darbuotojų darbo palengvinimas, irašant ir teikiant žinias studentams, pačių studentų dalyvavimas valdant duomenis (pvz., pirminis praktiku sutarčiu sudarymas ir registravimas, registravimasis studijuoti laisvai pasirenkamus dalykus, apklausų apie dėstymo kokybę pildymas), studentams skirtos informacijos (paskaitų ir egzaminų tvarkaraščių, studijų rezultatu, isakymu, imoku ataskaitų) operatyvus ir tikslus pateikimas, duomenu studiju kokybei gerinti gavimas - studijų rezultatų ataskaitos, studentų apklausos ir kt. Studijų posistemio duomenų bazė glaudžiai susieta su kitomis VGTU informacinès sistemos duomenų bazèmis - su darbuotojų duomenų baze, ūkinès ir finansinès veiklos bei kt.

Informacinès sistemos tobulinimas - vienas pagrindinių studijų kokybės valdymo uždavinių. Siekiama, kad studijų programų ir studijų dalykų duomenų bazè būtų operatyviai atnaujinama, kuriant naujas studijų programas ar atnaujinant vykdomas, kuriant ar tobulinant studiju dalykus.

2014 m. informacinèje sistemoje igyvendintas dalinių studijų klausytojų registras, jų individualaus studijų plano pildymas, studijų rezultatų apskaita, baigimo pažymų išdavimas.

VGTU informacinès sistemos studentų duomenų bazè tiesioginėmis sąsajomis susieta su Lietuvos studentų registru. Nuolat vykdyti duomenų perdavimo tobulinimo darbai. 


\section{Informacinès technologijos studijų procese}

Studijų procesui naudojamos 55 kompiuterių klasès ir laboratorijos, kuriose įrengta daugiau nei 900 kompiuterinių darbo vietų. Šiuose kompiuteriuose skirtingose klasėse i̇diegta per 240 ìvairių kompiuterinių programų, kurios naudojamos studijuojant apie 500 studiju dalykų. Studentai turi galimybę vykdyti modeliavimo, projektavimo ir kitus skaičiavimus tokiais pasaulyje žinomais ir plačiai naudojamais programų paketais, kaip Ansys, AutoCAD, ArcGis, Bentley, Cosmos, SolidWorks, Matrix Frame, Phoenics, STAAD Pro, Statistica ir kt. Šiu programinių paketų licencijos kasmet atnaujinamos, atsižvelgiant i naujų programų versijų reikalavimus, atnaujinama klasèse ir kompiuterinè iranga.

Norėdami studijuoti savarankiškai, atlikti namų, kursinius ar baigiamuosius darbus studentai, prisijungę prie universitete įdiegto studijų programinès įrangos portalo, nuotoliniu būdu gali naudotis ìvairia programine iranga. Portalas veikia 24 val. per parą, 7 dienas per savaitę, todèl bet kuriuo paros metu studentai ir dèstytojai gali naudotis programine įranga, jos nereikia įsidiegti i savo kompiuterị. Ji pasiekiama per interneto naršyklę adresu http://studsoft.vgtu.lt (3.3 pav.). Tokiu debesų kompiuterijos principu studentai gali naudoti daugiau nei 40 skirtingu programų.

\section{Programinè įranga VGTU studijoms}

Programinè įranga

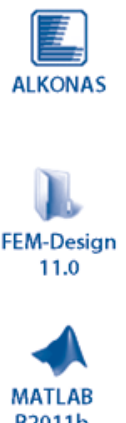

R2011b
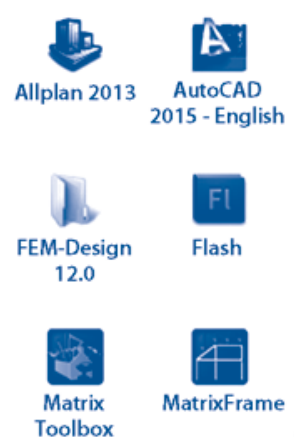

Flash

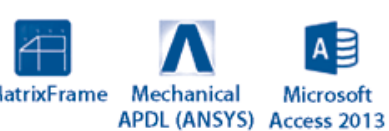
14.0

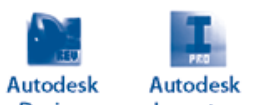

$\begin{array}{cc}\text { Design } & \text { Inventor } \\ \text { Review } 2013 & \text { Professional }\end{array}$
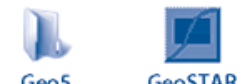

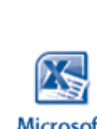

Excel 2013 Excel 2013

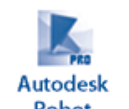
Robot
Structural

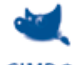

GIMP 2

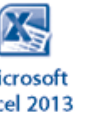

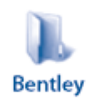

Bentley

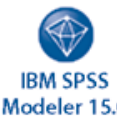

Modeler 15.0

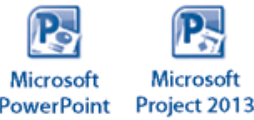

2013
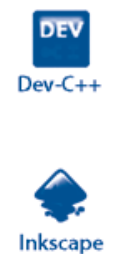
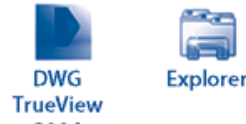

2014
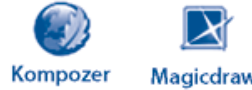

UML
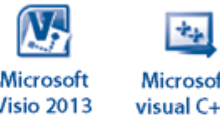

Microsoft

visual $\mathrm{C}_{++}$ 2010 Express

3.3 pav. Studiju programinès įrangos portalo pagrindinio lango fragmentas

Universiteto doktorantai ir magistrantai turi galimybę naudoti lygiagrečiujų ir paskirstytujų skaičiavimų išteklius. Universiteto lygiagrečiujų skaičiavimų laboratorijoje veikia kompiuterių telkinys, kuri sudaro 100 procesorių. Telkinio pajėgumai naudojami sudètingiems uždaviniams, reikalaujantiems didelių skaičiavimo išteklių, spręsti. Jame i̇diegti modeliavimo paketai GAMESS, NWChem, GROMACS, programavimo kalbų C/C++, Fortran kompiliatoriai, MPI bibliotekos, Intel ClusterToolkit, kurie naudodami matematinio modeliavimo, bioinžinerijos, skaičiuojamosios mechanikos ir kt. studijų dalykų magistrantų ir doktorantų atliekamiems didelès apimties skaičiavimams.

VGTU Nuotolinių studijų centre, atsižvelgiant i pasaulines ir Lietuvos aukštujų mokyklų studijų organizavimo tendencijas, aktyviai naudojama bendra Moodle virtuali aplinka, kurioje galima teikti informaciją apie dėstomus dalykus, idėti studiju medžiagą, organizuoti bendravimą su studentais, pateikti testus ir užduotis, greitai ịvertinti studentų pažangumą ir aktyvumą, gauti statistinę informaciją. Remiantis Moodle pateikiamais duomenimis, tai yra lanksčiausia ir populiariausia virtualaus mokymo aplinka pasaulyje. Ja šiuo metu naudojasi apie 40 mln. vartotojų iš 210 pasaulio šalių. Nuo 2011 m. pradžios Moodle yra pagrindinè virtuali aplinka tarp Lietuvos universitetų. Lyginant su iki šiol Lietuvoje naudotomis virtualiomis studiju organizavimo aplinkomis, Moodle turi keletą labai ryškių pranašumų: paprasta ir intuityviai suprantama vartotojo sąsaja, daug informacijos apie naudojimąsi ịvairiomis integruotomis priemonėmis, daug parengtos pavyzdinės studijų medžiagos, populiarumas tarp vartotojų, lengvesnis administravimas. Ataskaitiniu laikotarpiu ir toliau buvo siekiama gerinti virtualios studijų aplinkos pritaikymą VGTU studijų procesui, atsižvelgiant ị studijų proceso reikalavimus, dėstytojų ir studentų pageidavimus. Atnaujinta vartotojo sąsaja sudaro galimybių atskirti ir padaryti informaciją, skirtą esamiems universiteto studentams ir besidomintiems nuotolinėmis studijomis VGTU, lengviau prieinamą.

Siekiant labiau integruoti elektroninių studijų galimybes ị bendrą studijų procesą, vykdoma virtualios studiju aplinkos integracija į bendrają universitetinę informacinę sistemą. Dèl šios integracijos elektroninès priemonès taptų ne tik labiau unifikuotos, bet ir lengviau pasiekiamos, sujungiamos kartu su kitais universiteto elektroniniais ištekliais. 
Didèjantis elektroninių studiju galimybių integravimas studijų procese yra neatsiejamas ne tik nuo lankstesnio studijų proceso, studijų kokybės gerinimo, bet ir nuo naujų iššūkių. Siekdamas nuolat tobulinti studijų kokybę VGTU bendradarbiauja su kitais Lietuvos universitetais. VGTU nuo $2010 \mathrm{~m}$. yra Lietuvos nuotolinio mokymosi tinklo palaikymo ir plètros konsorciumo narys. Konsorciumas sukurtas siekiant sujungti savo organizacini, technini, technologinị ir finansini potencialą, profesines žinias bei igūdžius, kartu užtikrinti ilgalaikị bendradarbiavimą vykdant Lietuvos nuotolinio mokymosi tinklo palaikymo ir plètros igyvendinimo priemones bei jas finansuojant. Šiuo metu konsorciumas vienija penkiolika Lietuvos aukštojo mokslo institucijų. VGTU šiuo metu yra konsorciumo veiklą administruojanti institucija. $2014 \mathrm{~m}$. isigyta naujos kartos darbastalio vaizdo konferencinè irangą, kuri praktiškai pakeitè universitete jau esamus sprendimus ir sudaro sąlygas kokybiškam bendravimui nenaudojant aukštos kokybès ir brangios techninès įrangos, o pasitelkiant esamus irenginius (stacionarūs, nešiojamieji ir planšetiniai kompiuteriai, išmanieji telefonai ir pan.). Minèta vaizdo iranga suteikia lankstumo ne tik vykdant studiju procesą, bendraujant déstytojams ir studentams, bet ir sudaro galimybes efektyviau bendrauti skirtingoms šalims vykdant mokslinius projektus, taip pat organizuojant administracijos darbą.

\section{Nuotolinių studijų organizavimas}

Vilniaus Gedimino technikos universiteto 2012-2020 metų veiklos strategijoje daug dėmesio skiriama universitetinėms studijoms. Tiesiogiai su nuotolinėmis studijomis siejami uždaviniai yra studijų prieinamumo didinimas ir mokymosi visą gyvenimą užtikrinimas.

Ataskaitiniu laikotarpiu VGTU nuotoliniu būdu studijuoti buvo priimama Statybos, Verslo vadybos, Fundamentinių mokslų, Mechanikos, Transporto, Elektronikos, Aplinkos inžinerijos fakultetuose. Nuotoliniu būdu buvo galima studijuoti pagal aštuonias pirmosios pakopos ir aštuonios antrosios pakopos studiju programas. Nuotoliniu būdu buvo vykdomos išlyginamosios studijos Fundamentinių mokslų ir Verslo vadybos fakultetuose.

Nuotolinių studijų procesas organizuojamas pagal 2013 m. balandžio 24 d. rektoriaus isakymu Nr. 380 patvirtintą Vilniaus Gedimino technikos universiteto nuotolinių studijų organizavimo tvarkos aprašą. Šiame apraše įtvirtinamas lankstesnis, i studentą labiau orientuotas nuotolinių studijų organizavimas, studijų medžiagą pateikiant skirtingomis formomis ir sudarant galimybes dėstytojo ir studentų bendravimui realiuoju laiku naudojant pažangias komunikacines priemones.

Didinant studijų prieinamumą, analizuojami ne tik metodologiniai klausimai, bet ir techninių išteklių užtikrinimo ir tobulinimo dalykai. 2014 m. Nuotolinių studijų centre pertvarkyta nuotolinių studijų klasè, kuri buvo padalyta i keturias nedideles vaizdo konferencijų studijas. Naujai įrengtose studijose sudaryta galimybė dėstytojams rengti paskaitų vaizdo įrašus, transliuoti paskaitas organizuojant vaizdo konferencijas. Studentai, negalintys atvykti i paskaitas, gali klausytis paskaitų, bendrauti su dėstytojais ir tarpusavyje vaizdo konferenciju būdu. Tokiu būdu siekiama sudaryti sąlygas studijuoti bet kurioje vietoje ir studiju procesą padaryti prieinamesni. Studijuojančiu pagal pirmosios pakopos nuotoliniu būdu teikiamas studijų programas skaičiui padvigubejjus ir tikintis jo didejjimo ateinančiais metais, planuojama papildomai įrengti dar keturias specializuotas vaizdo konferencijų studijas. Gerinant dėstytojų darbo sąlygas, tokias specializuotas vaizdo konferencijų studijas numatoma įrengti skirtingose miesto vietose išdėstytų fakultetų patalpose.

Svarbiu nuotolinių studiju prieinamumo gerinimo rodikliu galima laikyti tai, kad dalis studentų mokosi būdami užsienyje. Taip pat nuotoliniu būdu studijuoja didelę judejjimo negalią turintys asmenys.

VGTU Architektūros rūmuose įrengtoje Vaizdo konferencijų studijoje vedami seminarai, kursai, konferencijos, baigiamuju darbu gynimai. Organizuojami vietiniai ir tarpuniversitetiniai renginiai. Studijoje sumontuota aukštos kokybės techninè įranga, kurią naudojant gali būti perteikiamas geros kokybès vaizdas ir garsas internetu. Todèl prireikus renginiai organizuojami ne tik i studiją atvykusiems dalyviams, bet ir kitose Lietuvos aukštosiose mokyklose esantiems dalyviams. Geras interneto ryšys leidžia organizuoti ir tarptautines konferencijas, seminarus, baigiamujų darbu gynimus.

Nuotolinių studijų priemonès naudojamos ne tik specializuotose nuotoliniu būdu teikiamose pirmosios pakopos bakalauro studijose, bet ir kitose nuotolinèse bei iprastose studijose. Vaizdo konferencijų sprendimai studentu pageidavimu pradedami naudoti ir antrosios pakopos nuotolinèse studijose. Per kai kurias paskaitas vaizdo konferenciju metu bendraujama su užsienio specialistais, taip realiai igyvendinant virtualaus mobilumo idejas. 


\section{Praktinis studentų mokymas}

Studentų praktika - viena svarbiausių studijų programos dalių, supažindinanti studentus su studijų metu igytu teorinių žinių naudojimu ir taikymo galimybėmis. Studentų praktika privaloma visoms VGTU pirmosios pakopos studiju programoms. Praktikos tikslas - ugdyti studentu gebejjimus praktikoje taikyti teorines žinias, igytas universitete. VGTU pirmosios pakopos studiju studentams 2014 m. buvo vykdomos pažintinės, mokomosios ir gamybinès arba profesinès veiklos praktikos, o antrosios pakopos - pedagoginès, profesinès veiklos ir mokslinès veiklos praktikos. Universitete sukurta decentralizuota praktikų valdymo sistema: fakultetai ir katedros ieško praktikos vietu studentams, bendradarbiauja su įmonėmis, prižiūri, kaip vykdomos studentu praktikos. Universitete praktikas reglamentuoja dokumentų rinkinys: trišalė studentų praktinio mokymo sutartis, praktikų programos, praktikų organizavimo tvarkos aprašas. Pirmosios pakopos nuolatinių studiju studentai turi atlikti ne mažesnès kaip 15 kreditų apimties praktikas.

Visas praktikų duomenu apdorojimas kompiuterizuotas ir vyksta universiteto informacinejje sistemoje:

- Praktikų imonių skelbimai ir praktikų vadovų sąrašai pateikiami universiteto tinklalapyje.

- Praktinio mokymo sutartis pildoma universiteto informacinėje sistemoje „Medeinë“, studento praktinio mokymo sutartis gali būti pildoma pasirenkant lietuvių arba anglų kalbas.

Studentu praktikos integravimas i studijų procesą atsispindi ir rengiant kursinius projektus bei baigiamuosius darbus: praktikos metu igytą patirti perteikia kursinių projektų ir baigiamujų darbu tematika. VGTU studentams suteikiama galimybè atlikti ir papildomają praktiką, kuri nėra numatyta studiju programoje. Ji atliekama laisvu nuo studiju laiku.

2014 m. praktikas atliko 3107 pirmosios pakopos studentai, 103 antrosios pakopos studentai ir 61 vientisujų studijų studentas. Vienu iš universiteto 2014-2020 m. plètros strategijos siekiamų stebėsenos rodiklių patvirtintas pirmosios pakopos studijų programų, kuriose numatyta atlikti ne trumpesnes kaip aštuonių savaičių praktikas, vykdymas. Dalyje studijų programų tokios trukmès praktikos jau atliekamos, kitos pertvarkomos taip, kad studentai turètu galimybę profesinès veiklos praktiką atlikti nenutrūkstamai.

2014 m. daugiausia universiteto studentų profesinès veiklos praktikas atliko šiose įmonèse: AB „Lietuvos geležinkeliai“, Priešgaisrinès apsaugos ir gelbėjimo departamente prie Vidaus reikalų ministerijos, UAB Vilniaus lokomotyvų remonto depe, $A B$ „Vilniaus rentinys“, UAB „Vilpros pramone““.

Nuolat daugejja studentu, atliekančių praktikas užsienyje. Šią galimybę igyvendinti padeda universitete vykdomi tarptautiniu praktiku organizavimo projektai.

\section{Studijų kokybès užtikrinimas}

Studiju kokybės užtikrinimas VGTU apima Europos erdvės aukštojo mokslo kokybės užtikrinimo nuostatose (ESG) nurodytas sritis:

Kokybės užtikrinimo politika ir procedūros - vidinę kokybės vadybos sistemą Vilniaus Gedimino technikos universitete pagrindžia kokybės strategijos metmenys. Vidinè kokybės vadybos sistema užtikrina veiklos kokybę igyvendinant VGTU misiją ir siekiant statute numatytų tikslų.

Studiju programu ir suteikiamu kvalifikaciju patvirtinimas, stebėsena ir periodinis vertinimas - universitete yra įteisinta studijų programų ir suteikiamų kvalifikacijų patvirtinimo, stebėsenos ir periodinio vertinimo tvarka.

Studentu rezultatu vertinimas - studentų studiju rezultatai vertinami naudojantis viešai paskelbtame Vilniaus Gedimino technikos universiteto studentų žinių vertinimo tvarkos apraše nustatytais kriterijais, metodais ir procedūromis. 2014 m. priimtas VGTU akademinio pažangumo gerinimo priemoniu planas.

Dėstymo kokybės užtikrinimas - universitete užtikrinama, kad akademinis personalas būtų kvalifikuotas ir kompetentingas; tam vykdoma: dėstytojų atrankos kriteriju reglamentavimas (VGTU dèstytojų, mokslo darbuotojų ir kitų tyrèjų konkursų eiti pareigas organizavimo ir atestavimo bei minimalių kvalifikacinių reikalavimų nustatymo tvarka, patvirtinta Senato 2012 m. rugsèjo 25 d. nutarimu Nr. 59-2.4); 2014 m. patvirtintas dėstytoju pedagoginès kvalifikacijos tobulinimo planas, kuriame numatyti aštuonių seminaru ciklai; patvirtintas akademinių užsièmimų tikrinimo tvarkos aprašas, kuriuo remiantis stebima dėstomų paskaitų kokybė; metodinės medžiagos analizè ir aptarimas; dėstytojų stažuočių, dėstytojų skaitomų paskaitų užsienio kalba universitete ir kituose universitetuose pagal tarptautines mainų programas analizė ir aptarimas; dèstytojams suteikti mokslo laipsniai; dèstytojų vadovavimo baigiamiesiems darbams analizè.

Studiju ištekliai ir parama studentams - universitete užtikrinama, kad kiekvienos studijų programos studentų ir klausytoju studijoms reikalingi ištekliai būtų tinkami ir pakankami. Vertinamas dèstytojų ir administracinio personalo, tenkančių vienam studiju programos studentui, skaičius, studentų nuomonès tyrimai; materialiniai ištekliai - universiteto biblioteka, auditoriju skaičius ir vietų skaičius auditorijose, praktikų vietos; metodiniai ištekliai (vadovèliai, knygos, duomenų bazès); universiteto informacinès technologijos, universiteto padaliniai. 
Informacijos sistemos - universitete užtikrinama, kad būtų kaupiama, analizuojama ir naudojama tinkama informacija, padedanti veiksmingai vykdyti studiju programas ir studiju procesą. Kaupiami studentų duomenys, rezultatų rodikliai informacinèje sistemoje Alma Informatica; studijų dalykų aprašai, konspektai ir kt. mokomosios priemonès pateikiamos elektroninių studijų aplinkoje, internetiniuose puslapiuose.

Viešas informavimas - universitete nuolat skelbiama naujausia tiksli ir nešališka kiekybinè bei kokybinė informacija apie vykdomas studiju programas ir suteikiamas kvalifikacijas: viešai pateikiami studiju programu ir studijų dalykų aprašai; viešai skelbiami studiju programų akreditavimo rezultatai; viešai pateikiami studijas universitete reglamentuojantys dokumentai; pagrindiniai veiklos rodikliai. Visa kiekybinè ir kokybinè informacija pateikiama universiteto tinklalapyje.

Siekiant užtikrinti nuotoliniu būdu teikiamų studijų kokybę, nuolatos atliekamas naujai sukurtų arba nuotoliniu būdu dėstomų esamų studijų dalykų aprobacija. Aprobaciją pagal VGTU patvirtintą vidaus tvarką atlieka universitetinè nuotolinių studijų medžiagos aprobavimo komisija. Keičiantis poreikiams ir siekiant efektyvesnio nuotoliniu būdu teikiamų studijų ivertinimo 2013 m. balandžio 25 d. rektoriaus įsakymu Nr. 385 patvirtintas naujas Vilniaus Gedimino technikos universiteto nuotolinių studijų medžiagos aprobavimo tvarkos aprašas. Lyginant su senuoju aprašu, nuotoliniu būdu organizuojamų studijų vertinimas numatytas nebe vienu, o keliais atvejais. Tai sudaro galimybių vertinti ne tik nuotoliniu būdu teikiamą studijų medžiagą, bet ir šiuo būdu pateiktą mokomają medžiagą, numatyta galimybė studijų procese naudoti iš dalies parengtą nuotolinių studijų medžiagą, kuri tobulinama studijų metu, taip pat papildomai vertinti svarbius nuotoliniu būdu teikiamos studijų medžiagos patobulinimus.

VGTU Nuotolinių studiju centro darbuotojai dalyvauja specializuotuose mokymuose, parodose, prisideda prie nuotolinių studijų veiklą reglamentuojančių dokumentų rengimo. VGTU darbuotojams nuolatos teikiamos konsultacijos dèl nuotolinių studijų medžiagos rengimo, teikiama metodinė pagalba organizuojant vaizdo konferencijas ir seminarus. Per 2014 m. Moodle virtualioje aplinkoje dirbti buvo mokyta apie 80 VGTU dèstytojų. Tuo tikslu buvo organizuojami mokymai dėstytojų grupėms, vykdomos nuolatinės individualios dėstytojų konsultacijos.

\section{Grįžtamasis ryšys studijų kokybės užtikrinimo procese}

Grižtamojo ryšio sistemos sukūrimo ir igyvendinimo studiju procese tikslas - veiksmingai ir sistemiškai stebèti studiju proceso kokybę. Studentai - lygiaverčiai akademinio proceso dalyviai, universitetas vadovaujasi kolegialumo principu išklausydamas kuo daugiau bendruomenès narių ir siekdamas gerinti studijų proceso organizavimą. Grižtamasis ryšys užtikrinamas sistemingai atliekant studentų apklausas ir naudojant apibendrintus apklausų rezultatus studijų programoms tobulinti, studijų proceso organizavimui gerinti, akademinio personalo sudèčiai ir gebèjimams stiprinti.

VGTU nuolat vykdomos studentu apklausos:

1. Visų universiteto studentų apklausa apie dėstytus dalykus ir juos dėsčiusius dėstytojus.

2. Pirmosios pakopos pirmo kurso studentų nuomonès tyrimas apie studijų pasirinkimą universitete.

Universiteto informacinejje sistemoje sėkmingai veikia automatizuota studentų apklausų sistema. Naudojantis automatizuota apklausu sistema, per metus organizuojamos dvi studentu apklausos apie dėstytus dalykus ir juos dėsčiusius dėstytojus - po žiemos ir pavasario sesijų. Apklausų metu vertinamas dėstymo metodų taikymas, parengtos medžiagos ir pasiruošimo paskaitoms kokybè. Individualius kiekvienos apklausos rezultatus gali stebèti dėstytojas, o vadovaujamo padalinio - katedros vedejjas ir dekanas. Studiju programų komitetu pirmininkai stebi ir analizuoja kuruojamos studijų programos apklausos rezultatus.

Kasmet vykdomas pirmosios pakopos pirmo kurso studentų nuomonės tyrimas apie studiju pasirinkimą universitete. $2014 \mathrm{~m}$. dauguma studentu pažymėjo, kad rinkosi studijas VGTU, nes tik šiame universitete yra norima studijuoti studiju programa ir kad baigę VGTU bakalauro studijas dirbs įdomų ir perspektyvų darbą bei isidarbins pagal igytą išsilavinimą.

Universitete nuolat analizuojami apklausų rezultatai. Jie aptariami rektorato posėdžiuose, akademiniuose universiteto padaliniuose, susitikimuose su studentais. Atsižvelgiant i studentų išsakytą nuomonę, ieškoma sprendimų studiju procesui tobulinti ir vykdoma gautu grižtamojo ryšio rezultatų sklaida.

\subsection{Studentų ir absolventų skaičius}

Lietuvos statistikos departamento duomenimis, nuo 2010 m. iki 2014 m. bendras studentu skaičius Lietuvos universitetuose sumažèjo nuo 133600 iki 94 381, t. y. 39219 studentu (arba apie 29,3 \%). Per metus nuo 2013 m. iki 2014 m. studentų Lietuvoje sumažèjo 10542 studentais, t. y. 10 \%. VGTU studentu skaičius per šiuos metus sumažejo 125-iais. Studentu skaičius procentine išraiška nuo viso Lietuvos universitetų studentų skaičiaus išlieka panašus ir 2014 m. sudarè 11,2 \% (3.4 pav.). Tai aktyvaus VGTU bendruomenès darbo, 
formuojant studentų kontingentą, kuris per pastaruosius penkerius metus išliko stabilus, o paskutiniais metais, palyginti su bendruoju studentų skaičiumi Lietuvos universitetuose padidejo, rezultatas.

2014 m. spalio 1 d. duomenimis, VGTU pirmosios ir antrosios pakopų bei vientisujų studiju programose studijavo 10563 studentai, iš jų pirmojoje studijų pakopoje studijavo 8744 studentai, antrojoje - 1675 studentai, vientisuju studiju - 144 studentai (3.5 pav.). Daugiausia studentu studijuoja Transporto inžinerijos (1599 studentai), Verslo vadybos (1514 studentų) ir Statybos (1489 studentai) fakultetuose.

Vertinant studentų skaičiaus pasiskirstymą pagal studijų sritis - ir pirmojoje, ir antrojoje pakopose didžiausią procentą sudaro technologijos mokslų srities studentai - pirmojoje pakopoje ir vientisosiose studijose studijuoja 58,3 \% (5179 studentai), antrojoje pakopoje - 63,5 \% (1064 studentai) nuo visu studentų. Studentų skaičiaus pasiskirstymas pagal studijų pakopas ir studijų sritis pateiktas 3.6 pav. ir 3.7 pav. Išsamūs studentų skaičiai pagal programas, metus ir pakopas pateikti 3.5 ir 3.6 lentelèse.

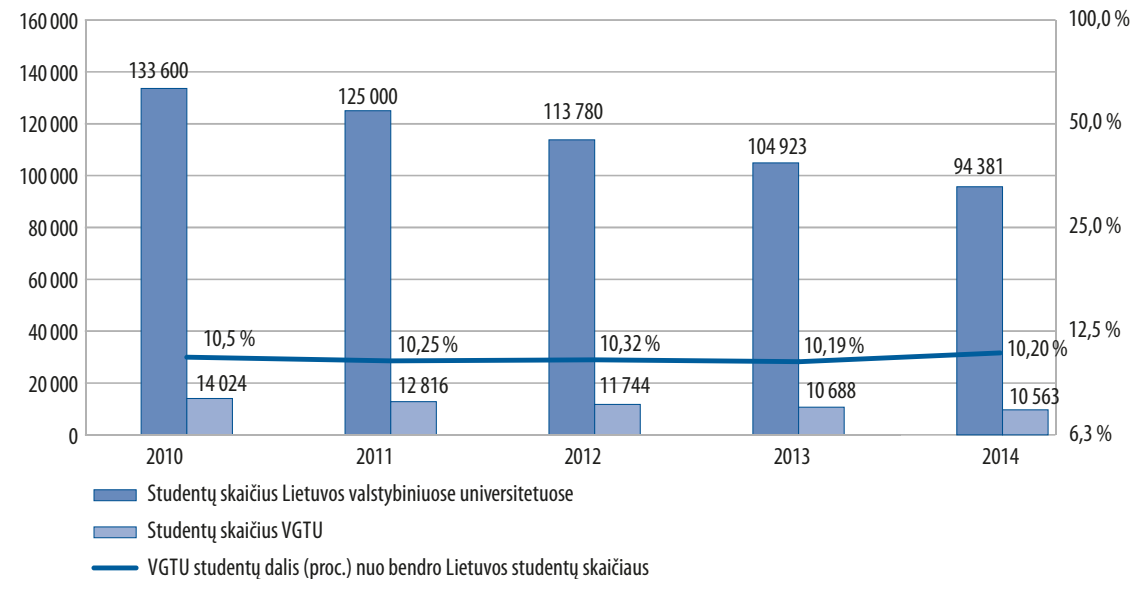

3.4 pav. VGTU ir bendras studentų skaičius Lietuvos universitetuose ir VGTU studentų dalis procentais nuo bendro Lietuvos studentų skaičiaus

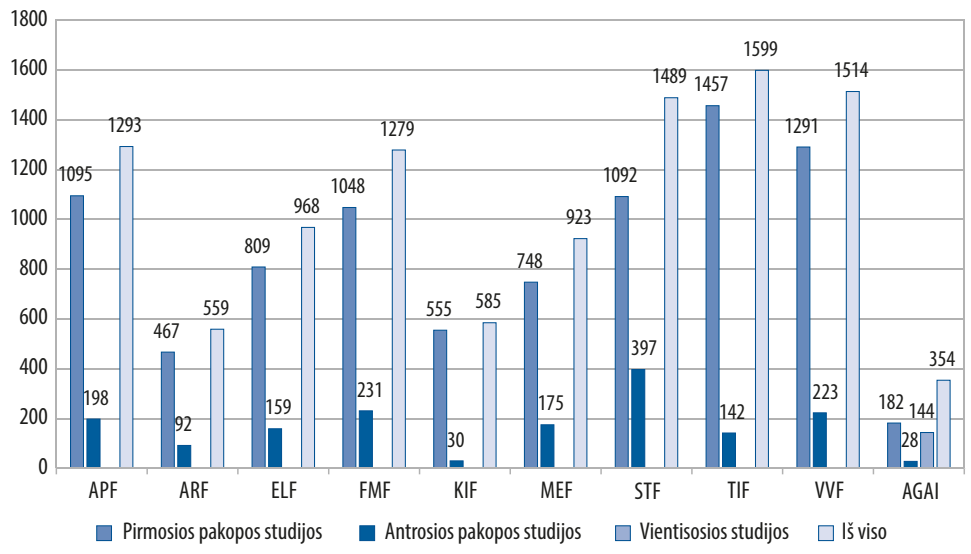

3.5 pav. Studentų skaičius pagal fakultetus 2014 m. spalio $1 \mathrm{~d}$.

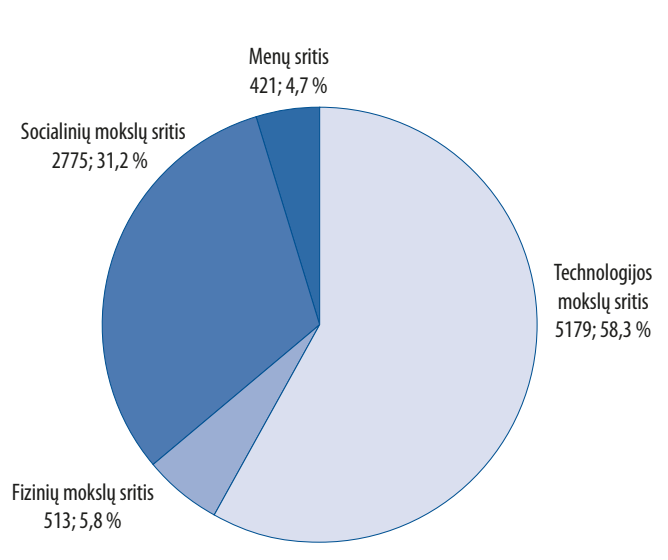

3.6 pav. Pirmosios pakopos ir vientisuju studijų studentų pasiskirstymas pagal studijų sritis $2014 \mathrm{~m}$.

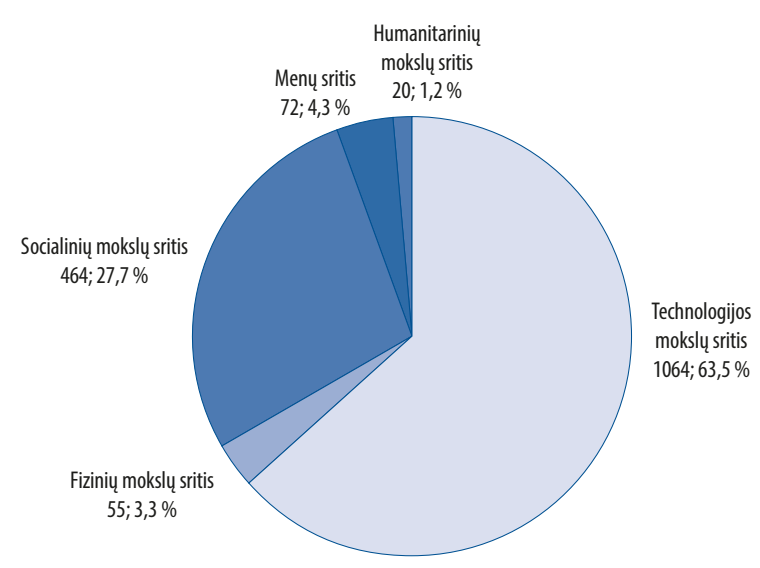

3.7 pav. Antrosios pakopos studentų pasiskirstymas pagal studiju sritis $2014 \mathrm{~m}$. 


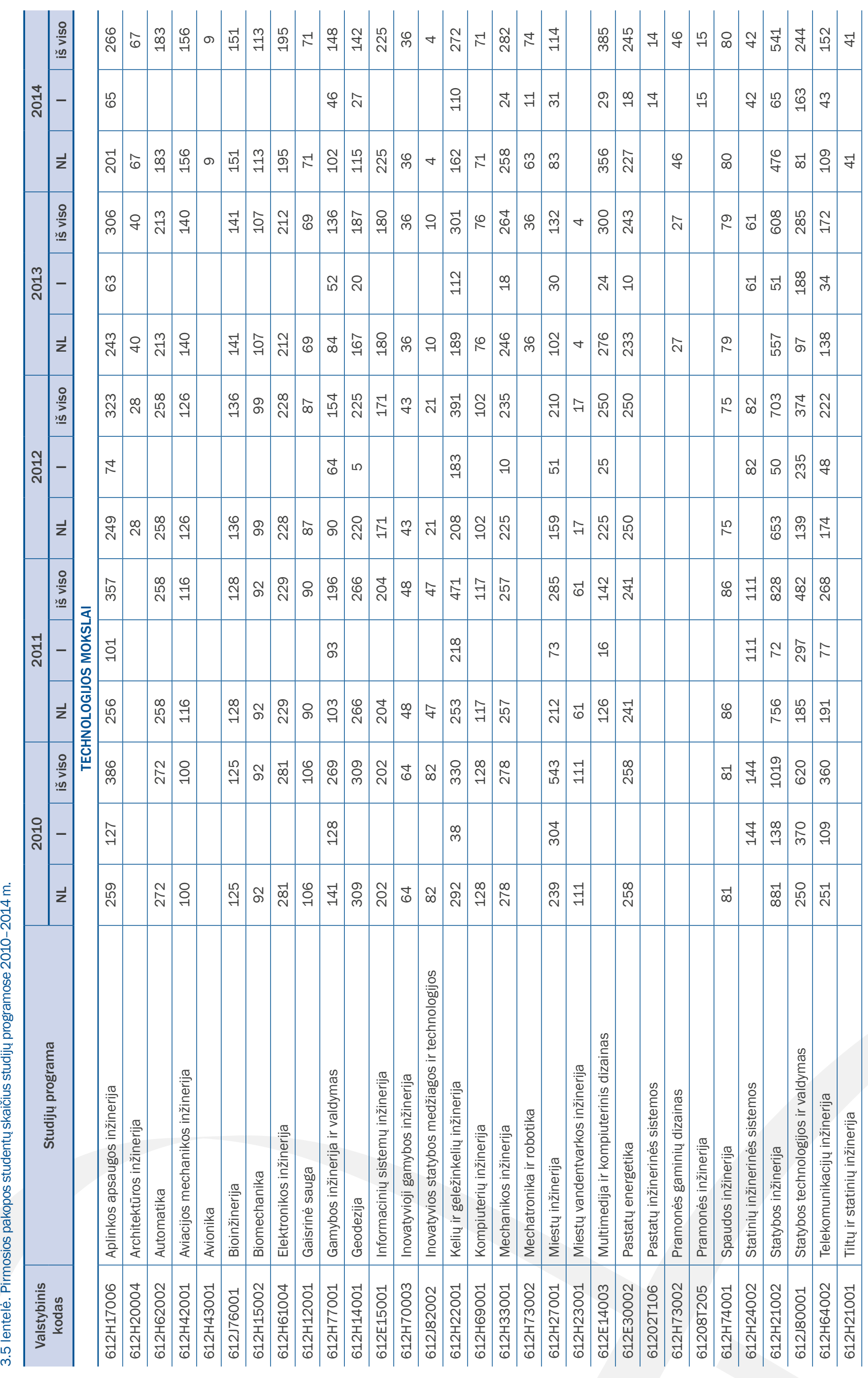




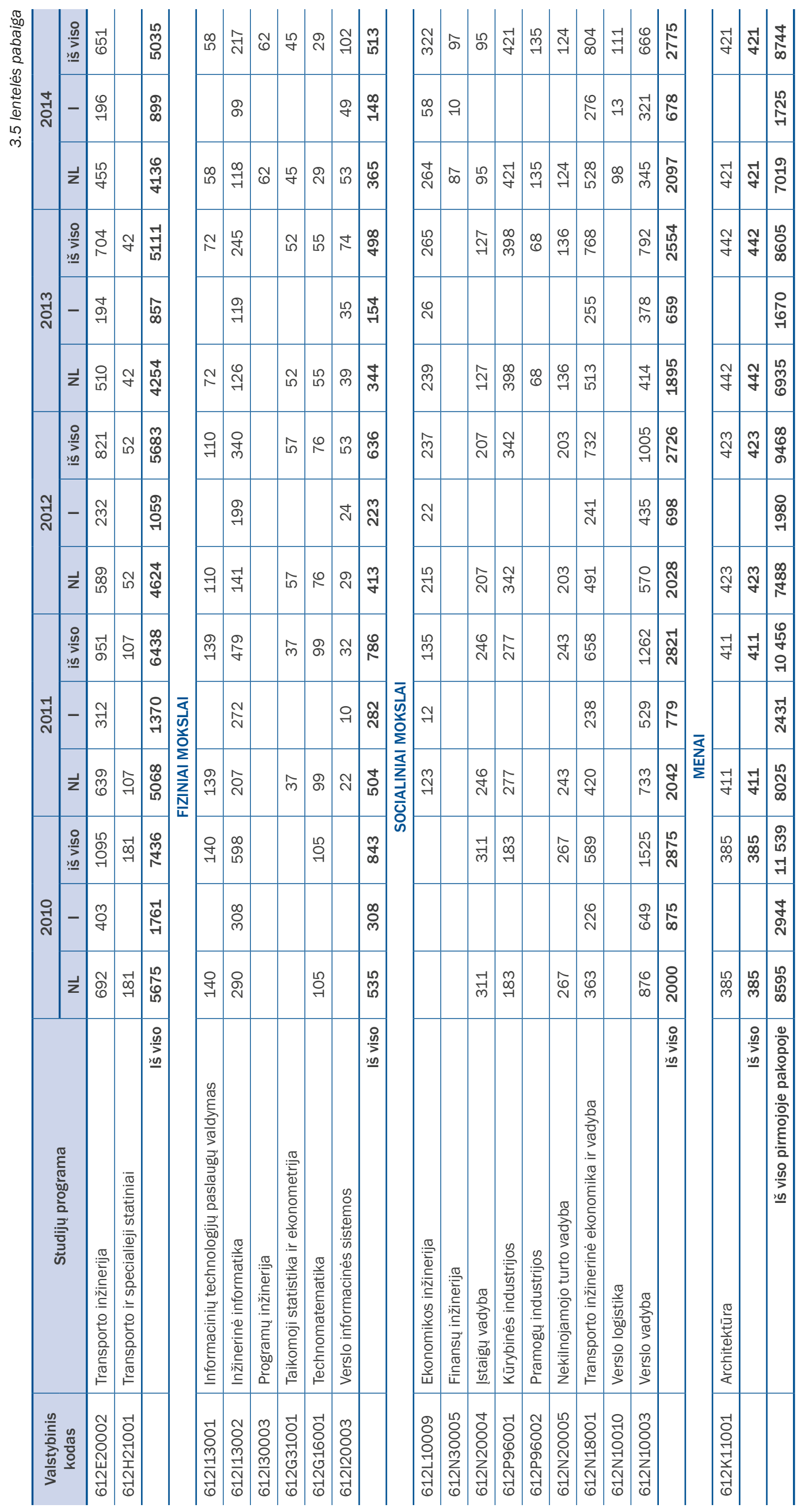




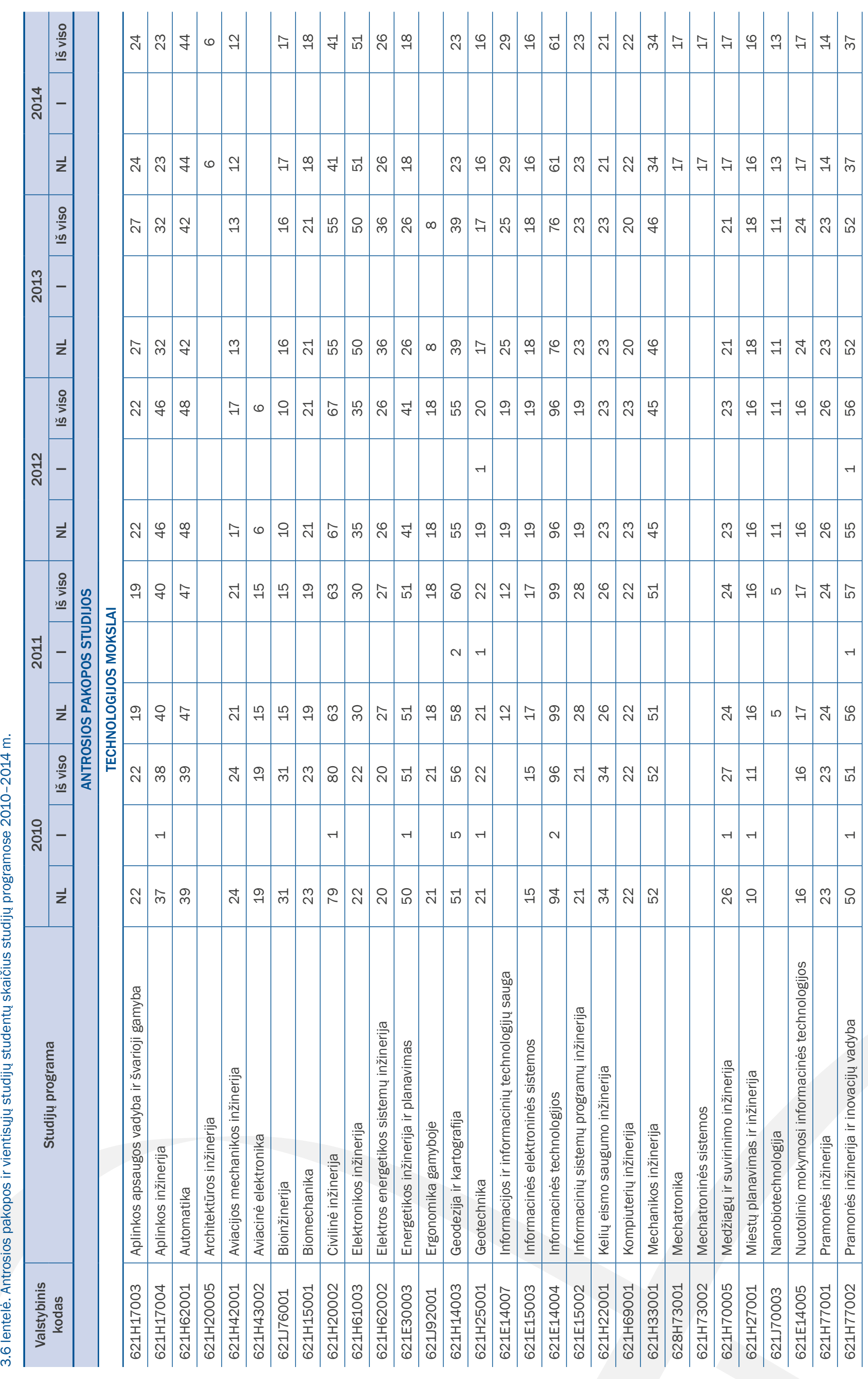




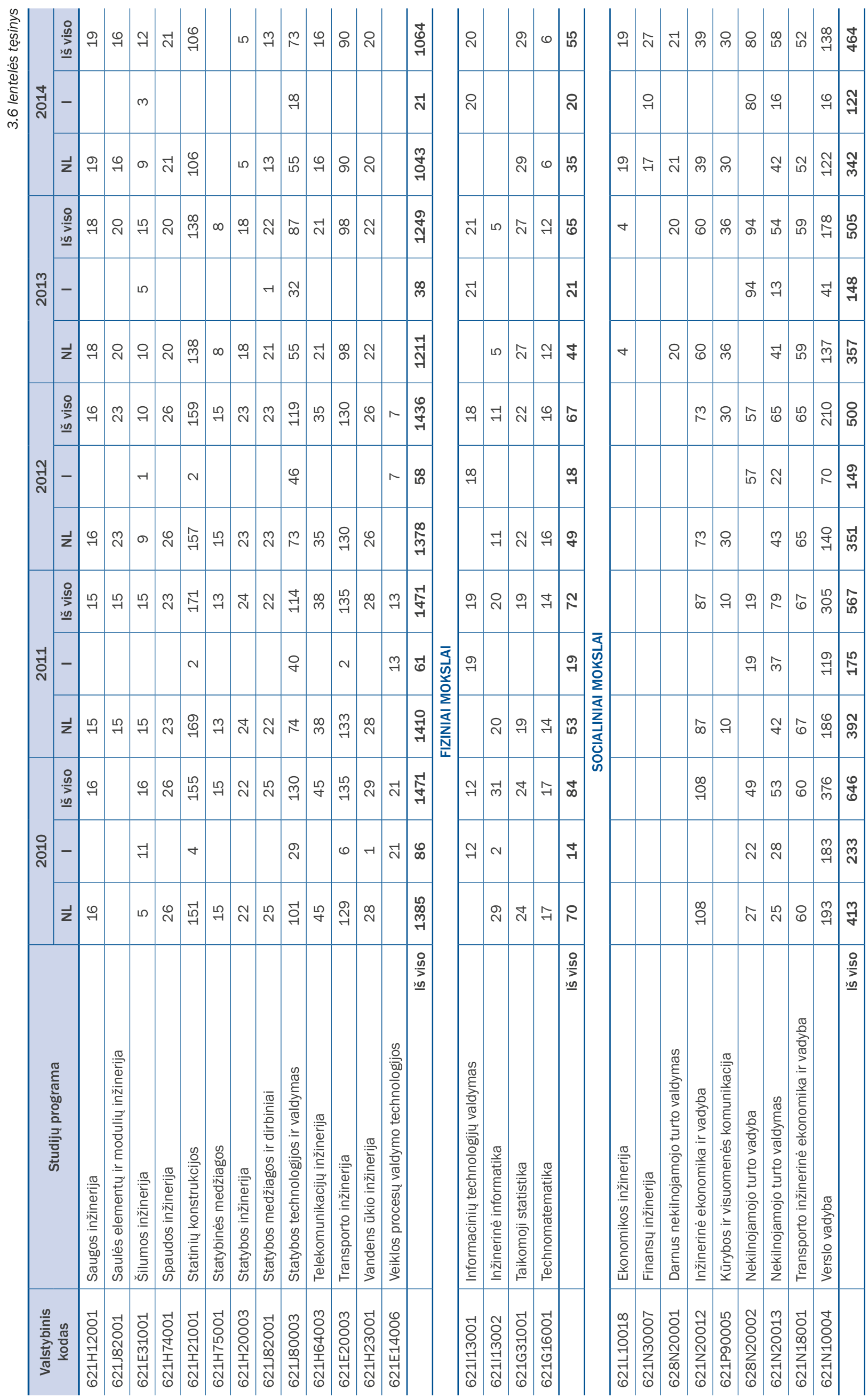




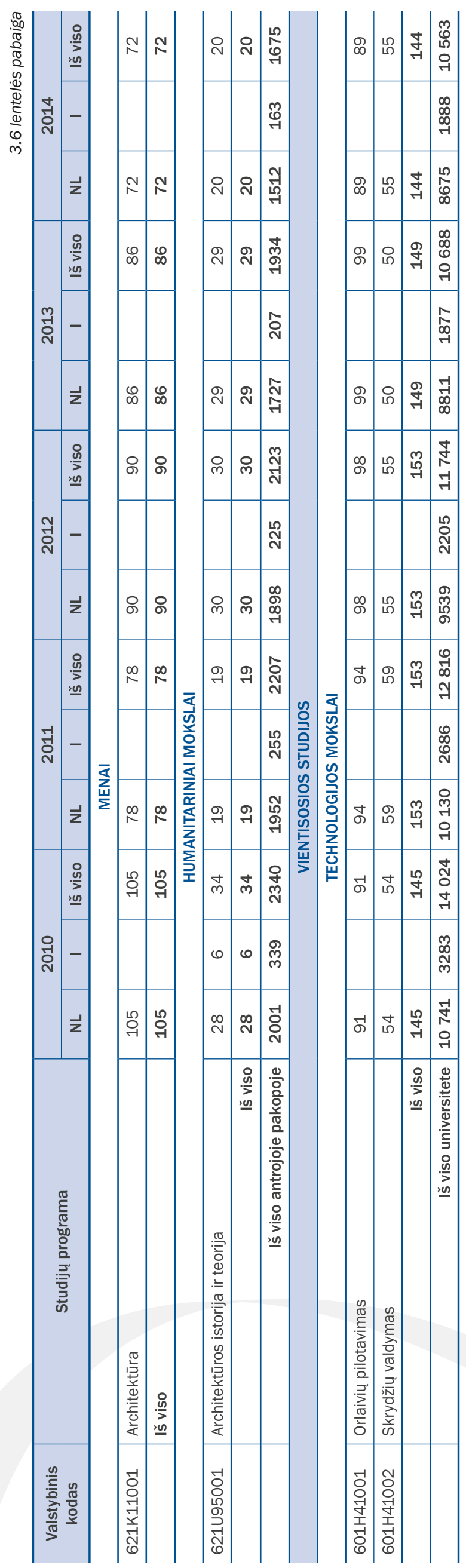


2014 m. VGTU baigė 53-ioji absolventų laida. Ją sudarè 2372 absolventai, iš jų pirmosios pakopos studijas baigè 1540 absolventų, antrosios pakopos studijas - 812, vientisąsias studijas - 20 absolventu (3.7 lentelè). Daugiausia absolventų studijavo Statybos fakultete - 415, Aplinkos inžinerijos fakultete - 395, Verslo vadybos fakultete - 313 (3.8 pav.). Didžiausią absolventų procentą sudaro technologijos mokslų srities absolventai 1461, t. y. $62 \%$ (3.9 pav.)

Per visą universiteto gyvavimo laiką nuo pirmosios absolventų laidos 1962 m. iki 2014 m. spalio 1 d. išduota 71756 aukštojo universitetinio mokslo baigimo, bakalauro, magistro, inžinieriaus ar diplomuoto inžinieriaus diplomų (3.8 lentelè). Nemaža dalis absolventų, igijusių universitete bakalauro laipsnị, toliau studijas tęsia VGTU magistrantūroje.

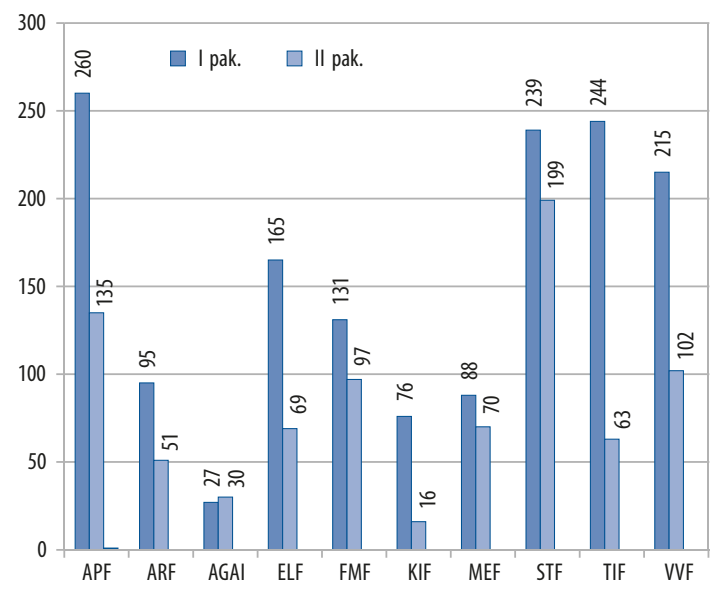

3.8 pav. 2014 m. absolventų skaičius pagal fakultetus

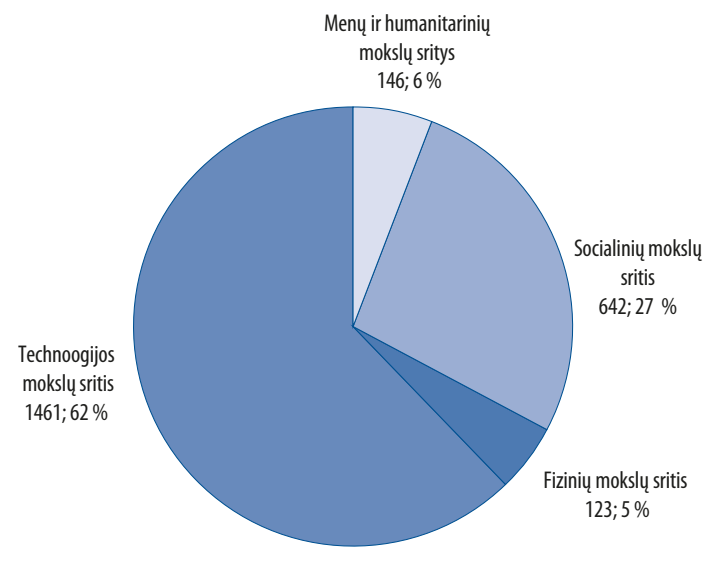

3.9 pav. 2014 m. absolventų skaičius pagal studijų sritis

3.7 lentelè. Absolventų skaičius pagal pakopas ir fakultetus 2014 m. spalio $1 \mathrm{~d}$.

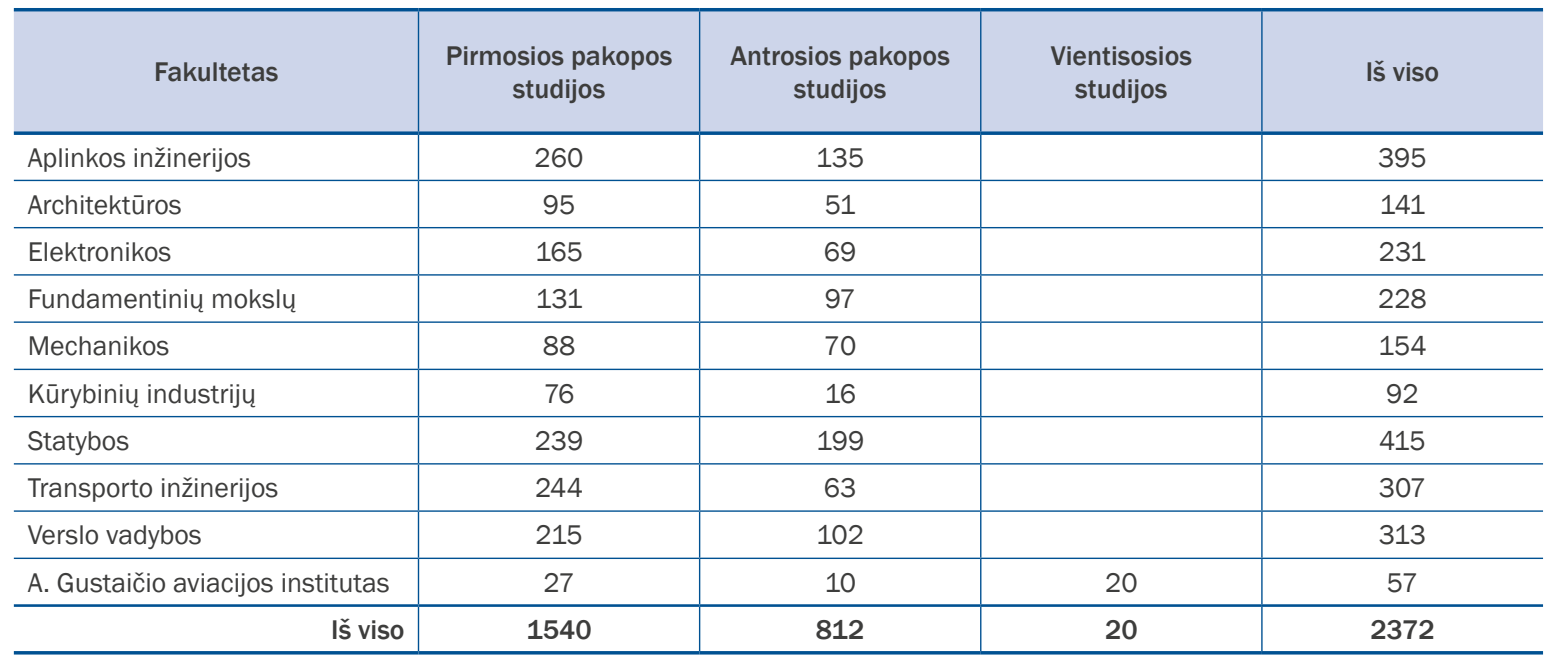

3.8 lentelè. Bendras baigusių studijas studentų skaičius

\begin{tabular}{|c|c|c|c|c|}
\hline $\begin{array}{c}\text { Aukštoji mokykla } \\
\text { (absolventų laidų laikotarpis) }\end{array}$ & \multicolumn{4}{|c|}{ Baigè aukštają mokyklą } \\
\hline Vilniaus inžinerinis statybos institutas & 18023 & & & 18023 \\
\hline Vilniaus technikos universitetas & 4902 & 452 & 253 & 5607 \\
\hline Iš viso & 56339 & 14496 & 921 & 71756 \\
\hline
\end{tabular}




\subsection{Prièmimas ị pirmosios pakopos studijas}

Vilniaus Gedimino technikos universiteto stojančiujų prièmimo rezultatai rodo, kad esame stabilus ir modernus universitetas, garsejjantis geromis tradicijomis, stipriu, kūrybingu darbuotoju potencialu. Universitetas tvirtai siekia užsibrėžtų tikslų - gerinti studiju programų kokybę, užtikrinti absolventų paklausą darbo rinkoje, plėsti ryšius su pasaulio aukštojo mokslo institucijomis. Universiteto siekį tapti augančiu, veikliu ir atviru visuomenei perteikia ir Stojančiujų prièmimo ir informavimo centro darbai.

2014 m. universitetinèms studijoms valstybinis finansavimas, lyginant su 2013 m., sumažèjo tik 1,3\%. Universitetiniu studijų technologijos, fizinių ir menų mokslu srityse 2014 m. planuotas valstybès finansuojamu vietų skaičius liko nepakitęs kaip ir 2013 m., socialinių mokslų srityje vietų skaičius sumažèjo 12,6 \% (3.10 pav.). Lietuvos aukštujų mokyklų asociacijos bendrajam prièmimui organizuoti (LAMA BPO) pateiktais duomenimis, 2014 m. bendrojo prièmimo konkurse i Lietuvos aukštąsias mokyklas dalyvavo ir konkurso reikalavimus ịvykdè 34431 stojantysis, tai maždaug tūkstančiu mažiau nei praejjusiais metais. Iš viso pasirašyta 27041 studiju sutartis, iš jų 7997 - i universitetų valstybès finansuojamas studijų vietas, 6814 - ị kolegiju (3.9 lentelè).

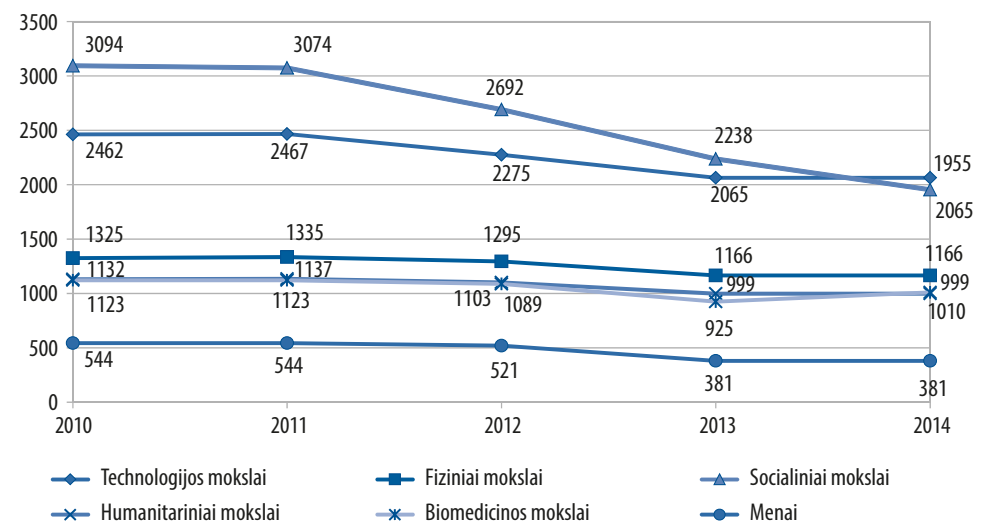

3.10 pav. 2010-2014 m. universitetams skirtų valstybės finansuojamų vietų skaičius (be tiksliniu būdu finansuojamų vietų ir dotacijų)

(šaltinis: Lietuvos aukštujų mokyklų asociacija bendrajam prièmimui organizuoti, prieiga per internetą: http://www.lamabpo.It)

3.9 lentelè. Pasirašyta studijų sutarčių per bendraji prièmimą 2014 m.

\begin{tabular}{|c|c|c|c|}
\hline Aukštosios universitetinès mokyklos (universitetai) & \multicolumn{3}{|c|}{ Pasirašyta studijų sutarčių } \\
\hline Vilniaus universitetas (VU) & 2315 & 1027 & 3342 \\
\hline Vilniaus Gedimino technikos universitetas (VGTU) & 1232 & 896 & 2128 \\
\hline Kauno technologijos universitetas (KTU) & 1430 & 575 & 2005 \\
\hline Lietuvos sveikatos mokslų universitetas (LSMU) & 436 & 600 & 1036 \\
\hline Aleksandro Stulginskio universitetas (ASU) & 312 & 530 & 842 \\
\hline Klaipėdos universitetas (KU) & 247 & 505 & 752 \\
\hline Lietuvos edukologijos universitetas (LEU) & 309 & 294 & 603 \\
\hline Vilniaus dailès akademija (VDA) & 239 & 85 & 324 \\
\hline ISM Vadybos ir ekonomikos universitetas (ISM) & 82 & 118 & 200 \\
\hline Lietuvos muzikos ir teatro akademija (LMTA) & 137 & 41 & 178 \\
\hline Kazimiero Simonavičiaus universitetas (KSU) & 29 & 124 & 153 \\
\hline Generolo Jono Žemaičio Lietuvos karo akademija (LKA) & 66 & - & 66 \\
\hline Vilniaus universiteto Tarptautinio verslo mokykla (VU TVM) & & 48 & 48 \\
\hline Balstogès universiteto filialas Vilniuje (BU FV) & 3 & 24 & 27 \\
\hline LCC tarptautinis universitetas (LCC) & 4 & 2 & 6 \\
\hline
\end{tabular}

Santrumpos:

vf - valstybės finansuojama vieta; vnf - valstybės nefinansuojama vieta; vnf/st - valstybės nefinansuojama vieta su studijų stipendija (šaltinis: LAMA BPO, prieiga per internetą: http://www.lamabpo.lt) 
2014 m. konkursas i universitetiniu studijų valstybės finansuojamas vietas buvo vykdomas pagal devyniolika studiju krypčių konkuravimo grupių. Atranka buvo vykdoma pagal LR švietimo ir mokslo ministro patvirtintą Geriausiai vidurinio ugdymo programą baigusiujų eilès sudarymo tvarkos aprašą.

Bendrojo prièmimo metu stojantieji galejo rinktis dvylika pageidavimu, nurodydami tris finansavimo pobūdžius: valstybės finansuojamą (vf), valstybės nefinansuojamą (vnf) ir valstybės nefinansuojamą su studiju stipendija (vnf/st). Stojantieji galejjo teikti atskirą prašymą i tiksliniu būdu finansuojamas vietas. VGTU buvo numatyta taip finansuoti triju studiju programų keturiolika finansuojamų vietų.

Studijuoti VGTU pirmosios pakopos studijose buvo priimti 2197 studentai, tai 251 studentu (11,4 \%) daugiau nei 2013 m., iš jų 1232 priimti ì valstybès finansuojamas vietas (3.11 pav.). Nepaisant sumažinto finansavimo socialinių mokslų studijų sričiai, studijuoti šios srities programose buvo priimta 23 studentais daugiau nei 2013 m. Pagal bendrą priimtujų skaičių VGTU tarp visų šalies universitetų užima antrają vietą ir pirmauja tarp universitetų, vykdančiu technologijos mokslų studijas. VGTU studijuoti valstybės nefinansuojamose vietose su studijų stipendija (kūrybinių industrijų studijų programoje) pasirašè studijų sutartis du asmenys. I tiksliniu būdų finansuojamas studijų vietas buvo priimti penki asmenys: vienas - i aviacinès mechanikos inžinerijos ir po du - i orlaivių pilotavimo bei gaisrinès saugos studiju programas.

Kaip ir ankstesniais metais, ar stojantysis gavo valstybės finansavimą, priklausė nuo šių pagrindinių kriterijų: brandos egzaminų ir metinių mokomujų dalykų ivertinimų ir papildomų balų, nuo studijų programų pasirinkimo eiliškumo, kitų stojančiujų studijų programų pasirinkimo bei aukštujų mokyklų organizuojamų bendrujų ir atskirujų stojamujų egzaminų arba testų (jei tokie numatyti taisyklèse) rezultatų.

2014 m. stojantieji galèjo rinktis iš 45-iu Vilniaus Gedimino technikos universiteto pirmosios pakopos studiju programų ir dviejų vientisujų studiju programų. Studijų formos - nuolatinè ir ištęstinè. Iš 47 minètų studijų programų 27 vykdomos nuolatine studijų forma, 17 - ištęstine ir nuolatine, 1 - tik ištęstine. Ištęstinių studijų septynios studiju programos suteikia galimybę studijuoti nuotoliniu būdu. Šioms studijoms vykdyti naudojamos pažangiausios informacinès komunikavimo technologijos ir populiariausia pasaulyje virtualaus mokymosi aplinka (Moodle sistema), užtikrinanti studijų prieinamumą visiems ir visur. Šiuolaikinio gyvenimo tempas lemia, kad nuotolinis studijų būdas tampa vis populiaresnis.

2014 m. prièmimui buvo pasiūlytos penkios naujos bakalauro studijų programos: finansų inžinerija, kokybės inžinerija, pastatų inžinerinis valdymas, programų inžinerija, verslo logistika.

Priimtujų i valstybės finansuojamas vietas skaičius, aukštas konkursinis balas, didelis pageidavimu prašymuose skaičius rodo nemažėjanti šių studijų programų populiarumą: transporto inžinerinės ekonomikos ir vadybos, transporto inžinerijos, architektūros, kūrybinių industrijų, pramogų industrijų, multimediju ir kompiuterinio dizaino, bioinžinerijos, orlaivių pilotavimo, mechanikos inžinerijos ir kt. Populiarios tarp stojančiuju buvo naujos studiju programos: finansų inžinerija, verslo logistika ir programų inžinerija. Nepatrauklia stojantiesiems pasirodè nauja pastatu inžinerinio valdymo ir kokybės inžinerijos studijų programos, kasmet i nepopuliarių studiju programų sąrašą patenka miestų inžinerija, inovatyvios statybos medžiagos ir technologijos, tiltų ir statinių inžinerija. Nesurinko reikiamo pageidaujančių studijuoti skaičiaus technomatematikos, taikomosios statistikos ir ekonometrijos studiju programos.

Priimtujų i pirmosios pakopos studijas pasi-

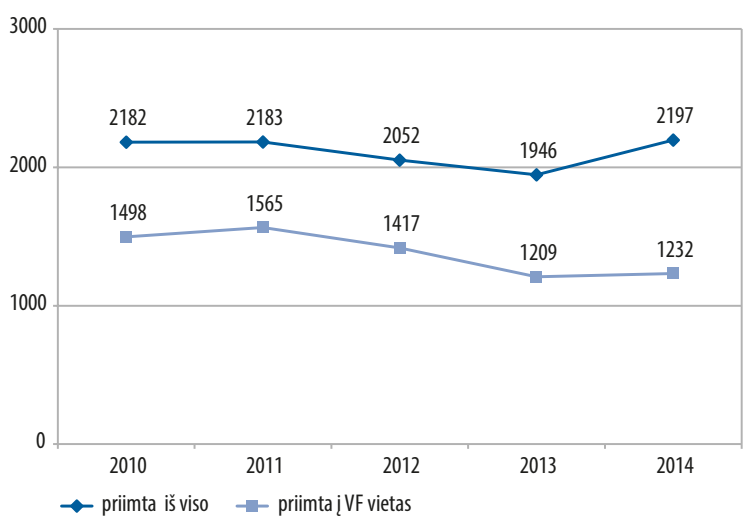

3.11 pav. Priimtuju i VGTU pirmosios pakopos ir vientisąsias studijas skaičiaus kitimas 2009-2014 m. skirstymas pagal studijų sritis, pateiktas 3.11 lentelèje ir 3.12 pav., rodo universiteto prioritetą technologijos mokslų studijos. Iš dvidešimties populiariausių per bendraji prièmimą (pagal pirmaji pageidavimą) technologijos mokslų studijų srities universitetinių programų devynios priklauso VGTU (pagal LAMA BPO IS duomenis): transporto inžinerija, multimedija ir kompiuterinis dizainas, statybos inžinerija, elektronikos inžinerija, aviacijos mechanikos inžinerija, automatika, informacinių sistemų inžinerija, kelių ir geležinkelių inžinerija, pastatu energetika.

Studiju programų populiarumą tarp stojančiųjų bendrojo prièmimo i Lietuvos aukštąsias mokyklas metu apibūdinanti statistika pateikta 3.12 ir 3.13 lentelèse. 
3.10 lentelè. Pateikta stojančiujų pageidavimų ir priimta i universiteto pirmosios pakopos ir vientisąsias studijas iki 2014 m. spalio $1 \mathrm{~d}$.

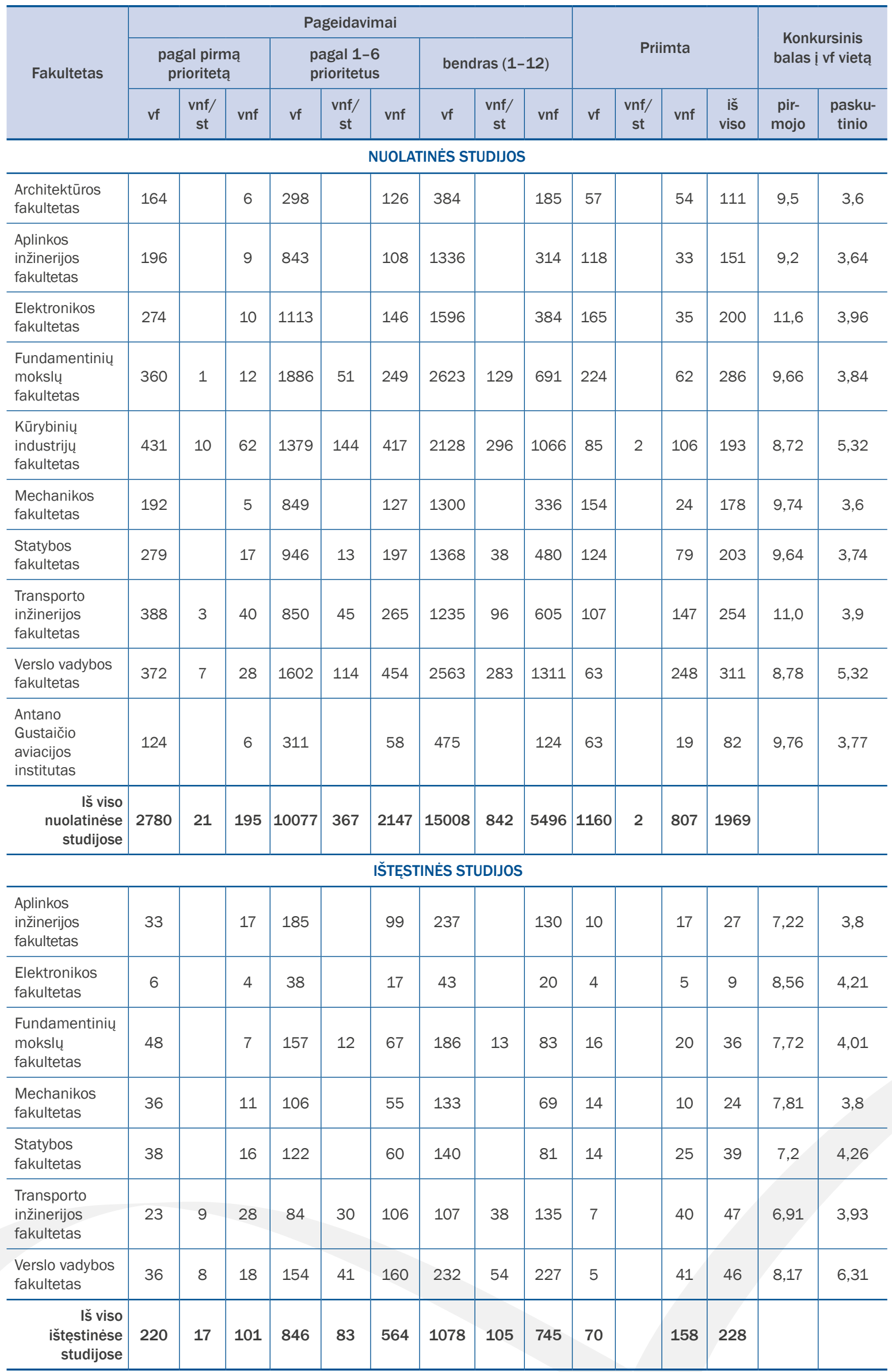

Santrumpos:

vf - valstybės finansuojama vieta; vnf - valstybės nefinansuojama vieta; vnf/st - valstybès nefinansuojama vieta su studijų stipendija. 
3.11 lentelè. Priimtujų i universitetą pasiskirstymas pagal studijų sritis iki 2014 m. spalio 1 d. (skliaustuose - 2013 m. duomenys)

\begin{tabular}{|c|c|c|c|c|c|c|}
\hline \multirow[b]{2}{*}{ Studijų sritis } & \multicolumn{6}{|c|}{2014 m. priimta (2013 m.) } \\
\hline & vf & $\begin{array}{c}\text { \% nuo visų } \\
\text { priimtujų i vf }\end{array}$ & vnf & $\begin{array}{c}\text { \% nuo visų } \\
\text { priimtujų } \\
\text { i vnf }\end{array}$ & iš viso & $\begin{array}{c}\text { \% nuo visų } \\
\text { priimtujų }\end{array}$ \\
\hline \multicolumn{7}{|c|}{ NUOLATINĖS STUDIJOS } \\
\hline Meno & $37(44)$ & $3,2(3,8)$ & $48(34)$ & $5,9(6,0)$ & $85(78)$ & $4,3(4,5)$ \\
\hline Technologijos mokslų & $862(897)$ & $74,2(77,0)$ & $200(167)$ & $24,8(29,5)$ & $1062(1064)$ & $53,9(61,5)$ \\
\hline Fizinių mokslų & $84(63)$ & $7,2(5,4)$ & $43(25)$ & $5,3(4,5)$ & $127(88)$ & $6,5(5,1)$ \\
\hline Socialinių mokslų & $179(161)$ & $15,4(13,8)$ & $516(338)$ & $64,0(60,0)$ & 695 (499) & $35,3(28,9)$ \\
\hline Iš viso nuolatinèse studijose: & $1162(1165)$ & & $807(564)$ & & 1969 (1729) & \\
\hline \% nuo visų priimtujų į nuolatines studijas: & & $59,0(67,4)$ & & $41,0(32,6)$ & & 100 \\
\hline \multicolumn{7}{|c|}{ IŠTĘSTINĖS STUDIJOS } \\
\hline Technologijos mokslų & $57(33)$ & $81,4(75,0)$ & $74(90)$ & $46,5(51,5)$ & $130(123)$ & $57,3(56,3)$ \\
\hline Fizinių mokslų & $8(11)$ & $11,4(25,0)$ & $14(6)$ & $8,9(3,5)$ & $22(17)$ & $9,7(7,9)$ \\
\hline Socialinių mokslų & $5(0)$ & $7,2(0)$ & $70(77)$ & $44,6(45,0)$ & $75(77)$ & $33,0(35,8)$ \\
\hline Iš viso ištęstinèse studijose: & $70(44)$ & & $158(173)$ & & $228(217)$ & \\
\hline \% nuo visų priimtujų j̣ ištęstines studijas: & & $30,8(20,5)$ & & $69,2(79,5)$ & & 100 \\
\hline Iš viso universitete & $1232(1209)$ & & $965(737)$ & & 2197 (1946) & \\
\hline$\%$ nuo visų priimtujų i studijas & & $56,1(62,2)$ & & $43,9(37,8)$ & & 100 \\
\hline
\end{tabular}

Santrumpos: vf - valstybės finansuojama vieta; vnf - valstybės nefinansuojama vieta.

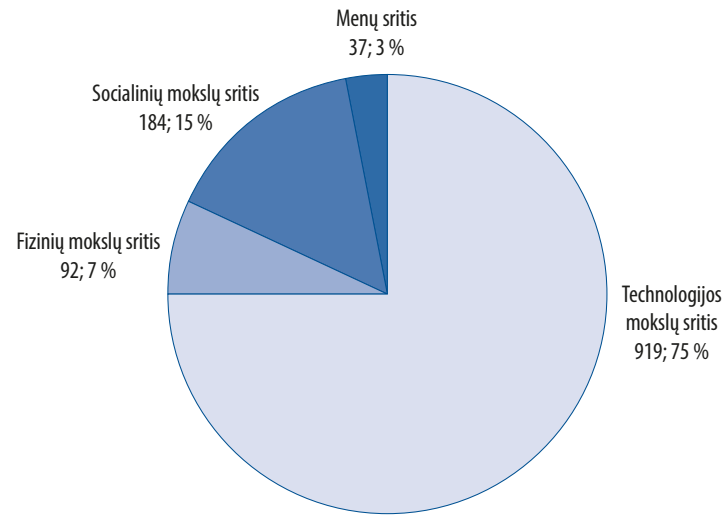

3.12 pav. Priimtujų i VGTU vf vietas pasiskirstymas pagal studijų sritis (skaičius ir procentai)

3.12 lentelè. Universitetinių studiju programu, 2014 m. per bendraji prièmimą surinkusių daugiausia valstybės finansuojamų, su studiju stipendija ir tikslinio finansavimo vietu, dešimtukas

\begin{tabular}{c|l|c}
\hline $\begin{array}{c}\text { Univer- } \\
\text { sitetas }\end{array}$ & \multicolumn{1}{|c|}{ Studijų programa } & $\begin{array}{c}\text { Pasirašyta vf vietų } \\
\text { studijų sutarčių }\end{array}$ \\
\hline VU & Ekonomika & 185 \\
\hline KTU & Programų sistemos & 144 \\
\hline LSMU & Medicina & 131 \\
\hline VU & Teisė & 131 \\
\hline VU & Medicina & 126 \\
\hline VU & Programų sistemos & 122 \\
\hline KTU & Maisto mokslas ir technologija & 116 \\
\hline MRU & Teisė ir policijos veikla & 111 \\
\hline VU & Politikos mokslai & 106 \\
\hline VGTU & Multimedija ir & 102 \\
\hline
\end{tabular}

3.13 lentelè. Universitetinių studijų programų, 2014 m. per bendraji prièmimą surinkusių daugiausia studentų, dešimtukas

\begin{tabular}{c|l|c}
\hline Universitetas & \multicolumn{1}{|c|}{ Studijų programa } & $\begin{array}{c}\text { Primtujų } \\
\text { skaičius }\end{array}$ \\
\hline LSMU & Medicina & 302 \\
\hline VU & Ekonomika & 253 \\
\hline MRU & Teisè ir policijos veikla & 231 \\
\hline VU & Teisè & 226 \\
\hline VU & Medicina & 192 \\
\hline LSU & Treniravimo sistemos & 190 \\
\hline KTU & Programų sistemos & 181 \\
\hline VGTU & $\begin{array}{l}\text { Transporto inžinerinè } \\
\text { ekonomika ir vadyba }\end{array}$ & 148 \\
\hline VDU & Kūrybinės industrijos & 134 \\
\hline KTU & Maisto mokslas ir technologija & 132 \\
\hline
\end{tabular}


Universitetas organizuoja studijas asmenims, turintiems aukštaji koleginị išsilavinimą. Vykdomas kolegiju absolventu prièmimas ị išlyginamąsias studijas siekiantiems igyti universitetinị išsilavinimą ir papildomąsias studijas norintiems igyti reikalingų žinių ir gebejjimų stoti į atitinkamo profilio magistrantūros studijas. Priimami atitinkamo profilio studijų programų kolegijų absolventai konkurso tvarka pagal diplomo priedèlio mokomuju dalykų svertinị ivertinimų vidurkị. Vykdomos dvylikos ištęstinių (I) arba ištęstinių nuotolinių (Int) studiju programų išlyginamosios studijos (2013 m. - devynių) (3.14 lentelè). Pateikti 2010-2014 m. prièmimo rezultatai rodo šių studijų paklausą.

3.14 lentelè. Kolegijų absolventų prièmimas ị išlyginamąsias studijas

\begin{tabular}{|c|c|c|c|c|c|c|}
\hline \multirow{3}{*}{ Aplinkos inžinerijos } & Aplinkos apsaugos inžinerija (I) & - & - & - & 9 & 8 \\
\hline & Geodezija (I) & - & - & - & 14 & 7 \\
\hline & Pastatų energetika (I) & - & - & - & 10 & 11 \\
\hline \multirow{2}{*}{ Mechanikos } & Gamybos inžinerija ir valdymas (I) & - & - & - & - & 6 \\
\hline & Mechatronika ir robotika (I) & - & - & - & - & 11 \\
\hline Statybos & Statybos technologijos ir valdymas (I) & 35 & 33 & 31 & 16 & 17 \\
\hline Transporto inžinerijos & Transporto inžinerija (I) & 22 & 26 & 27 & 48 & 37 \\
\hline Verslo vadybos & Verslo vadyba (In) & 46 & 50 & 63 & 98 & 43 \\
\hline & Iš viso & 208 & 232 & 226 & 316 & 301 \\
\hline
\end{tabular}

I papildomąsias vienerių metų studijas studijuoti pagal individualius planus priimti 25 kolegijų absolventai i 8 studiju programas Elektronikos, Fundamentinių mokslų, Kūrybinių industrijų, Mechanikos ir Verslo vadybos fakultetuose.

\subsection{Prièmimas ị antrosios pakopos studijas}

Stojančiujų prièmimo ir informavimo centras organizuoja ir vykdo prièmimą i Vilniaus Gedimino technikos universiteto magistrantūros studijas.

Kaip ir ankstesniais metais, valstybės finansuojamų vietų skaičių pagal konkrečias studijų kryptis skyrè LR Vyriausybè, atsižvelgdama i valstybès ūkinès, socialinès ir kultūrinès plètros poreikius ir finansines valstybès galimybes. 2014 m. aukštosioms mokykloms buvo paskirstytos 4625 valstybès finansuojamos antrosios pakopos studiju vietos. Valstybès finansuojamų vietų skaičius, lyginant su 2013 m., kiek padidèjo (0,04 \%).

LR Vyriausybès skirtas valstybès finansuojamas vietas universitetams paskirsto LR švietimo ir mokslo ministerija atsižvelgdama i aukštujų mokyklų mokslo (meno) veiklos rezultatus ir (arba) stojančiuju i pirmosios pakopos ir vientisuju studiju programų pasirinkimą pagal studijų ar mokslo krypti. Vilniaus Gedimino technikos universitetui $2014 \mathrm{~m}$. buvo skirtos 547 vietos (3.13 pav.) (apie $8 \%$ mažiau nei 2013 m.).

Bendrą VGTU gautų finansuojamų vietų skaičiu padidino gautas finansavimas iš projekto lèšu (septynios finansuojamų jungtinès mechatronikos studijų programos vietos skirtos iš projekto lěšų), tačiau pastaraisiais

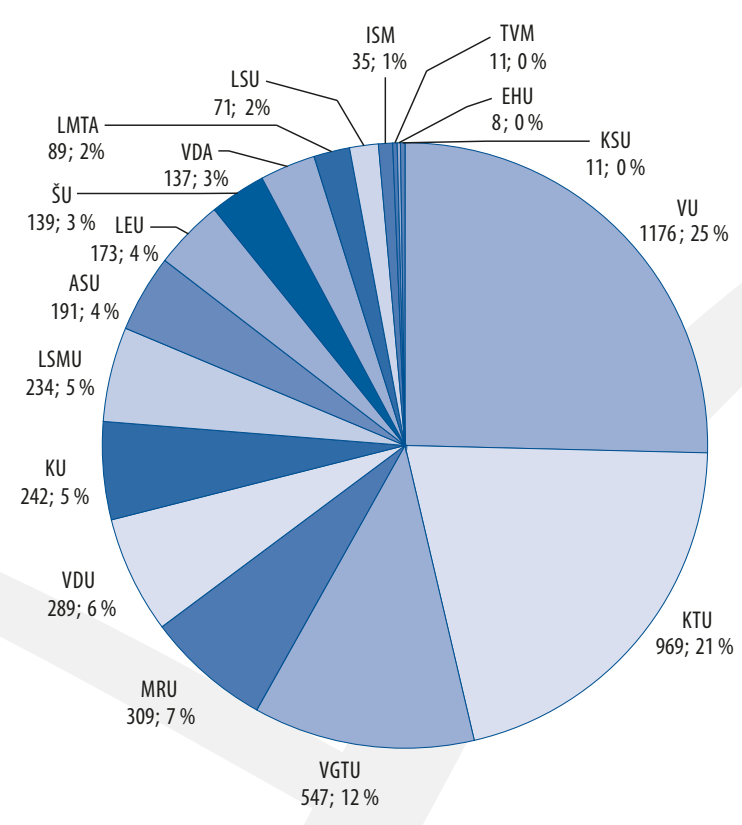

3.13 pav. Antrosios pakopos studijų valstybès finansuojamų vietų pasiskirstymas aukštosiose mokyklose 
metais vyrauja bendra tendencija - skiriamas valstybės finansavimas antrosios pakopos studijoms kasmet mažèja, dèl to mažeja ir bendras priimamų studentų skaičius.

Stojantiesiems i VGTU antrosios pakopos studijas 2014 m. buvo pasiūlytos 55 studijų programos. Iš jų septynias studiju programas galima studijuoti ištęstine studijų forma, o penkios studiju programos yra jungtinès (darnaus nekilnojamojo turto valdymo studiju programa vykdoma kartu su Kaliningrado valstybiniu technikos universitetu, inovatyvi kelių ir tiltų inžinerija vykdoma kartu su Rygos technikos universitetu, nekilnojamojo turto vadybos studiju programa vykdoma kartu su Baltarusijos valstybiniu technologijos universitetu, mechatronikos studiju programa vykdoma kartu su Vokietijos Braunšveigo technikos universitetu, o statinių ir jų aplinkos darnios plètros studiju programa vykdoma kartu su Maskvos valstybiniu M. V. Lomonosovo universitetu).

$2014 \mathrm{~m}$. iš viso buvo pateikti 1294 prašymai stoti j VGTU antrosios pakopos studijas. Apie 28 \% prašymų buvo pateikta ne VGTU absolventų. Tarp stojančiuju populiariausios buvo šios studijų programos (specializacijos):

- ekonomikos inžinerija (globalioji ekonomika);

- kūrybos visuomenès komunikacija;

- finansų inžinerija (investavimo vadyba);

- informacijos ir informaciniu technologiju sauga;

- verslo vadyba (verslo finansų valdymas).

Iš viso i VGTU antrosios pakopos studijas buvo priimti 772 studentai:

- 545 i valstybės biudžeto lěšomis finansuojamas vietas;

- 7 i projekto léšomis finansuojamas vietas;

- 220 i valstybès nefinansuojamas vietas.

Priimtuju i antrosios pakopos studijas pasiskirstymas pagal studiju sritis pateiktas 3.15 lentelèje, o pagal fakultetus - 3.14 pav.

Pastaraisiais metais priimtujų skaičius išlieka panašus (3.15 pav.). Mažèjantis valstybès finansuojamų vietų skaičius, didelè studijų kaina ir bendra šalies ekonominė situacija daro įtaką priimamų studentų skaičiui, ypač ì valstybės nefinansuojamų studijų vietas.

Kita vertus, aukštosios mokyklos padėti aukštojo mokslo sistemoje parodo kitų aukštujų mokyklų absolventu stojimas. Tarp stojančiujų i VGTU 28 \% prašymų pateikẻ ne VGTU absolventai. Iš viso i antrosios pakopos studijas buvo priimti 166 kitu aukštujų mokyklų absolventai, t. y. 21,5 \% istojusiujų buvo ne VGTU bakalaurai. Daugiausia istojo iš Vilniaus universiteto, Kauno technologijos universiteto, Lietuvos edukologijos universiteto (3.16 pav.), kurių dauguma rinkosi Kūrybinių industrijų, Architektūros, Verslo vadybos, Fundamentinių mokslų fakultetus.

3.15 lentelè. Priimtujų i universiteto antrają studijų pakopą pasiskirstymas pagal studijų sritis 2014 m. (skliausteliuose - 2013 m. duomenys)

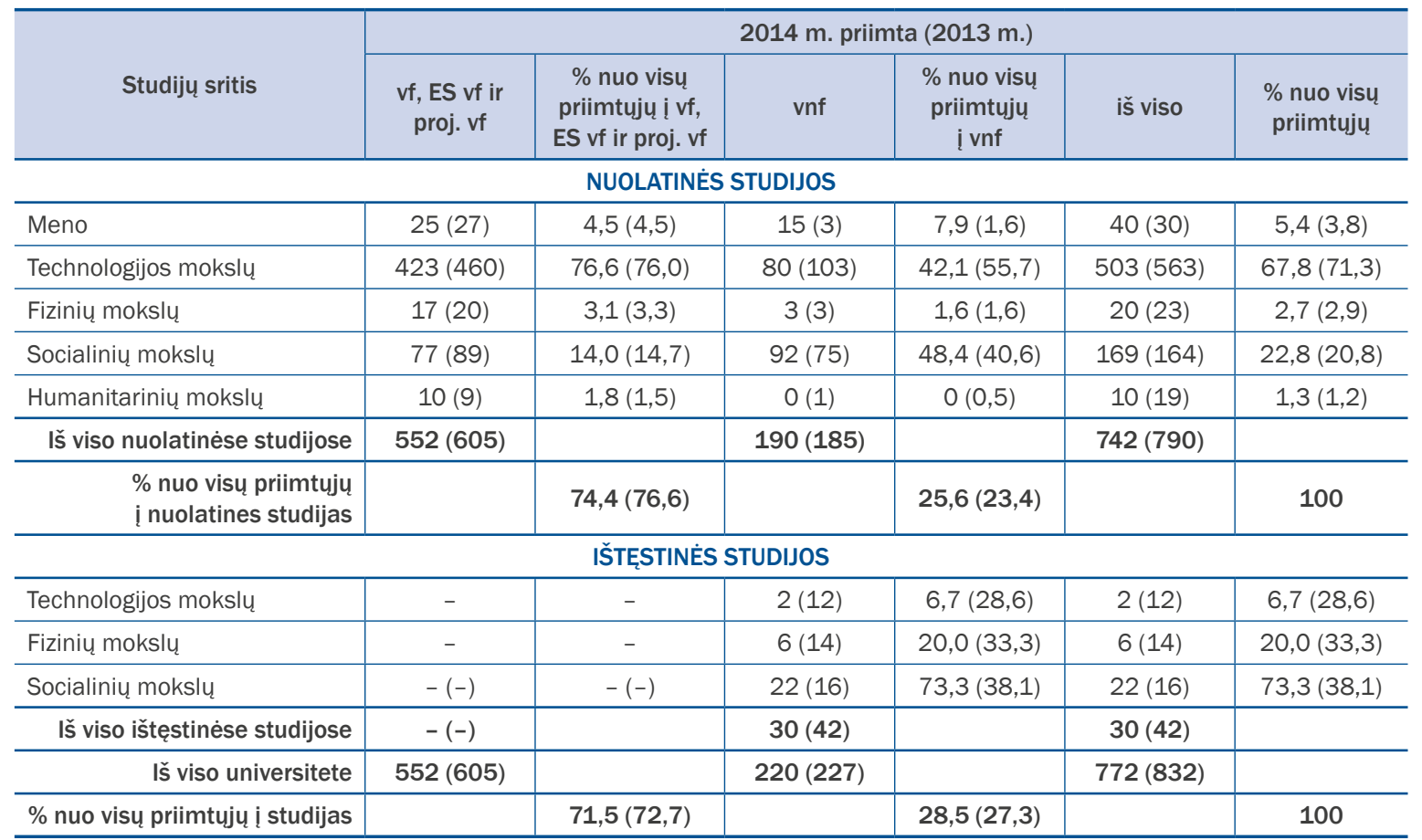

Santrumpos: vf - valstybès finansuojama vieta; ES vf ir proj. vf - finansuojama vieta iš ES struktūrinių fondų lèšų ir/ar projektų lèšų; vnf - valstybès nefinansuojama vieta. 


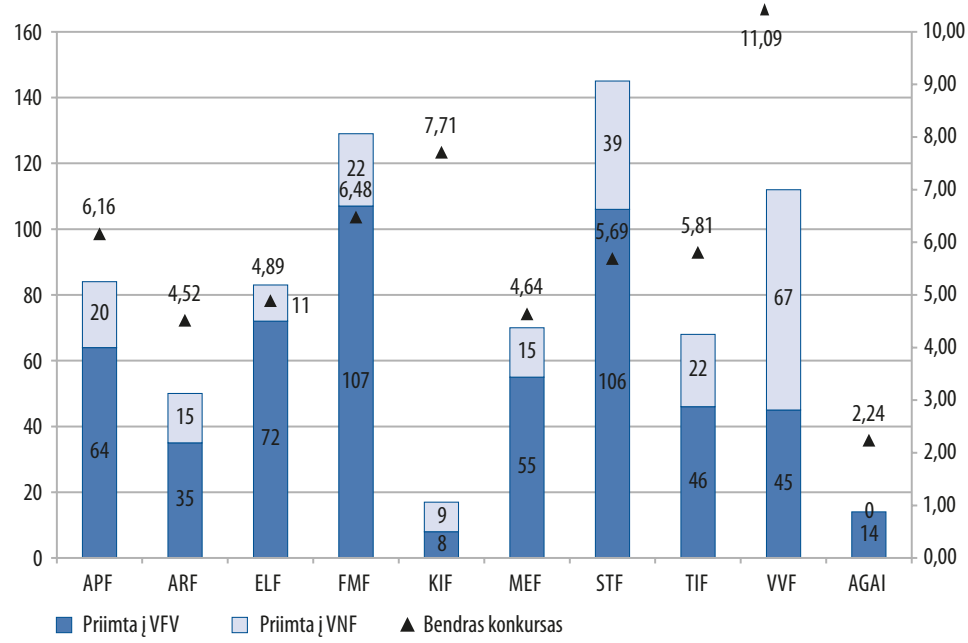

3.14 pav. Priimtuju i universiteto antrają studiju pakopą $2014 \mathrm{~m}$. pasiskirstymas pagal fakultetus

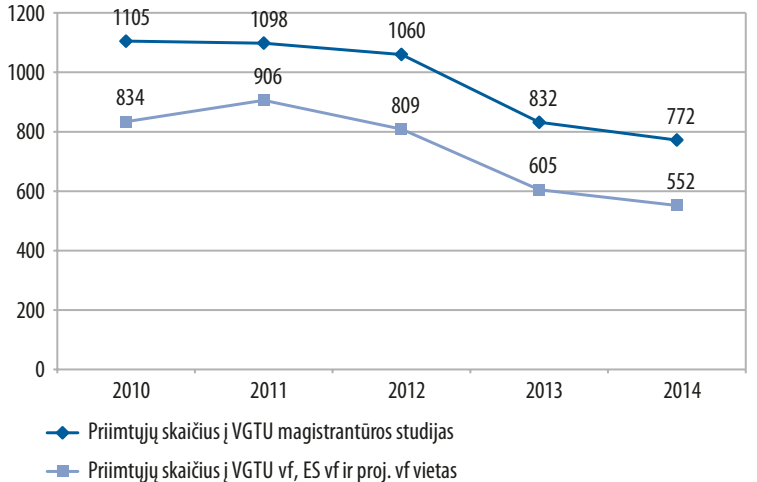

3.15 pav. Priimtujų i VGTU antrosios pakopos studijų valstybės finansuojamų vietų (taip pat ir ES struktūrinių fondų lėšų bei projektų lèšų finansuojamas vietas) bei bendro priimtujų skaičiaus kitimas 2010-2014 m.

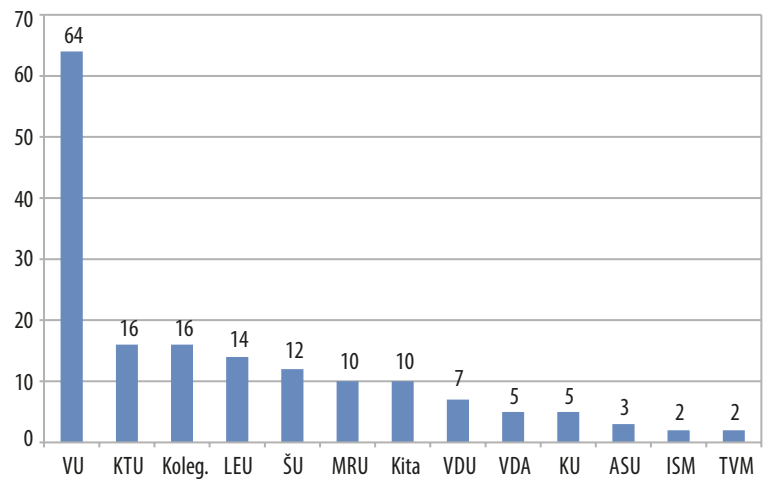

3.16 pav. Kitų aukštujų mokyklų absolventai, istoję i VGTU antrosios pakopos studijas 2014 m.

\subsection{Studijų tarptautiškumas}

\subsubsection{Dvišalis ir daugiašalis bendradarbiavimas}

VGTU tarptautinis atvirumas išlieka svarbus VGTU strateginės plètros principas. 2014 m. toliau daug dėmesio universitetas skyrè dvišalių partnerysčių analizei ir prioritetizavimui, atsižvelgiant i aktyvią ir abipusiškai naudingą partnerystę. Taip pat daug dèmesio 2014 m. buvo skirta pasiruošti Erasmus+ programai, kurios didžiausia naujovè - galimos dvišalės partnerystès ne ES šalyse.

2014 m. VGTU pasirašè septynias bendradarbiavimo studijų ir mokslo srityse sutartis su užsienio aukštojo mokslo institucijomis. Geografiškai VGTU strateginės kryptys siejasi su nacionaliniais aukštojo mokslo tarptautiškumo skatinimo programos geografiniais prioritetais. Aktyviai plètota partnerystè su Vidurinès Azijos regiono universitetais: atnaujinta dvišalè sutartis su Eurazijos nacionaliniu L. N. Gumiliovo universitetu (Kazachstanas), pasirašyta sutartis su Kaukazo universitetu (Azerbaidžanas), pasirašyta sutartis ir aktyviai plètojamas bendradarbiavimas su Kobe universitetu (Japonija), Nandžingo aeronautikos ir astronautikos universitetu (Kinija).

2014 m. VGTU dirbo su daugiau nei 80 universitetu partneriu pagal dvišalio bendradarbiavimo sutartis 22 šalyse: Europoje, Azijoje, Šiaurès ir Pietų Amerikoje (Azerbaidžane, Baltarusijoje, Brazilijoje, Čekijoje, Čilèje, Gruzijoje, Italijoje, Japonijoje, JAV, Kazachstane, Kinijoje, Latvijoje, Lenkijoje, Malaizijoje, P. Korèjoje, Prancūzijoje, Rusijoje, Slovėnijoje, Švedijoje, Taivane, Ukrainoje, Vokietijoje).

2014 m. universitetas buvo daugiau nei 60 tarptautinių ir nacionalinių tinklų bei asociacijų narys. Svarbiausios narystès, kuriose VGTU aktyviausiai dirbo 2014 m., yra BALTECH - septynių Baltijos regiono technikos universitetu konsorciumas, Centrinès ir Rytų Europos bendradarbiavimo tarp technikos universitetu platforma ir EUA - Europos universitetų asociacija. 
2014 m. pabaigoje VGTU bendradarbiavo su daugiau kaip 300 Erasmus programos partnerèmis aukštosiomis mokyklomis. Universitetas bendradarbiavo su 53 partneriais iš QS TOP 500.

Tarptautinio universitetų reitingo „QS World University Rankings“ sudarytojams paskelbus 2014-2015 m. Europos ir Centrinės Azijos šalių universitetų QS reitingą (QS EECA), du Lietuvos universitetai pateko ị regioninio reitingo 50-tuką. Vilniaus Gedimino technikos universitetas reitinge užima 47 vietą ir yra šalies technikos universitetų lyderis.

Tarptautiniame U-Multirank reitinge tarp 879 aukštojo mokslo institucijų iš 70 šalių VGTU tapo daugiausia (devynis) aukščiausių ịvertinimų surinkęs Lietuvos universitetas. Apie 60 \% (vertintų VGTU) rodikliu ịvertinti „Labai gerai“ arba „Gerai“. Bakalauro studijos anglų kalba ir studentų mobilumas užėmė aukščiausias pozicijas reitinge greta poveikio regionui, universiteto mokslininkų publikacijų dažniausiai cituojamuose leidiniuose, imonių kūrimosi (angl. spin-off), mokslininkų indèlio ì menus bei pritraukè finansinių investicijų iš privačių ir regioninių partnerių.

2014 m. universitetas tęsè parengiamuosius Erasmus+ programos darbus, kuri pakeičia dabartines mokymosi visą gyvenimą (MVG) programas. Universiteto dalyvavimas Erasmus+ programoje tampa nauja tarptautinès veiklos organizavimo sklaidos platforma, igyvendinant nacionalinius aukštojo mokslo tarptautiškumo plètros uždavinius, universiteto plètros strategiją ir Europos universitetų modernizavimo darbotvarkę.

Studijų programos užsienio kalba yra visos tarptautinės veiklos studijų srityje pagrindas, nes tai yra absolventų rengimo tarptautinei darbo rinkai kokybės užtikrinimo elementas, tarptautinių studentų ir dėstytojų mainų galimybės sukūrimas, galimybė pritraukti užsienio studentus VGTU laipsniui igyti; universiteto studiju kokybès ir tarptautinio konkurencingumo rodiklis, tarptautinio prestižo sąlyga. 2014 m. VGTU buvo vykdoma dvylika pirmosios pakopos studijų programų užsienio kalba ir aštuonios antrosios pakopos studiju programos užsienio kalba (iš jų dvi nuotolinès). Jungtinių ir dvigubo laipsnio programų kūrimas, vykdymas ir tolesnè plètra užtikrina studijų aplinkos ịvairovę ir kokybę, partnerių pripažinimą. Studijų užsienio kalba plètros tęstinumui svarbiausi yra šie uždaviniai: esamų pirmosios pakopos studijų programų užsienio kalba skaičiaus išlaikymas; antrosios pakopos studiju programų užsienio kalba plètra; dalinių studijų užsienio kalba (semestrų, akademinių metų ir pan.) galimybių sukūrimas fakultetuose, kurie nevykdo studijų užsienio kalba; laipsnio siekiančių užsienio studentų ir mainų studentų skaičiaus išlaikymas. 2014 m. studijų programos užsienio kalba sudarė $22 \%$ visų VGTU vykdomų studijų programų. Tai yra geras pagrindas kurti ir plètoti bendras programas su užsienio universitetais.

Tarptautiniai studijų projektai - viena iš daugiašalio bendradarbiavimo igyvendinimo formų, leidžianti pritraukti išorès finansavimą ir sutelkti partnerius universitetui svarbiems tikslams igyvendinti - tobulinti studiju kokybę, diegti studiju proceso inovacijas.

2009-2014 m. universitetas vykdè 75 tarptautinius studiju projektus. Vertinant atskiru metų rezultatus matyti, kad bendras projektų metinis biudžetas pasiskirsto netolygiai. Tai lemia projekto igyvendinimo fazė: dominuoja dvejų-trejų metų trukmės projektai, kuriuos igyvendinant pagrindinès veiklos ir jų finansavimas paprastai vyksta antraisiais projekto vykdymo metais.

Ataskaitiniu laikotarpiu VGTU koordinavo arba dalyvavo kaip partneris vykdant 37 studiju projektus (3.16 lentelè), kurių veiklai vykdyti universitetas 2014 m. gavo apie 650,5 tūkst. Eur, arba 2246 tūkst. Lt ịplaukų.

Pradėtas naujas Leonardo da Vinci projektas - „Keitimasis geraja patirtimi perduodant GEO profesinio švietimo naujoves, siekiant atitikti GEO darbo rinkos poreikius Europoje, atitinkančius ES politiką“. Universitetas sustiprino savo poziciją kaip projektų koordinatorius. 2014 m. buvo vykdomi trys VGTU koordinuojami TEMPUS projektai (NETCENG, CEN EAST, ECOMMIS), kurių bendras biudžetas visam projektų vykdymo laikotarpiui sudarè daugiau nei $11,7 \mathrm{mln}$. Lt.

\subsubsection{Tarptautinis mobilumas}

Tarptautinis studentų mobilumas yra tarptautinès veiklos prioritetas, sietinas su ES Tarybos rekomendacijomis dèl jaunimo mobilumo mokymosi tikslais skatinimo bei Europos aukštojo mokslo sistemų modernizavimo darbotvarkès igyvendinimu.

VGTU pradejjo Erasmus+ programą, pagal kurią tarptautinę darbo patirti gali igauti ir VGTU absolventai. 2014 m. liepos-gruodžio mẻn. stažuotis i užsienį išvyko 24 absolventai. Dar 17 absolventų išvyko remiamai konsorciumo „Patirties partneriai“. Šis konsorciumas - pirmasis Lietuvoje, jungiantis užsienio verslo įmones bei universitetus ir turintis Erasmus+ programos konsorciumo mobilumui akreditaciją. Konsorciumo veiklą koordinuoja Lietuvos pramonininkų konfederacija (LPK). Veiklos tikslas - didinti absolventu konkurencingumą tiek Lietuvos, tiek tarptautinėje darbo rinkoje, skatinti verslumą, užtikrinti efektyvesni absolventu issidarbinimą ES institucijose, tarptautinėse / regioninèse organizacijose ir tarptautinio verslo struktūrose. 


\begin{tabular}{|c|c|c|}
\hline MVG/Erasmus programa & Vykdymo laikotarpis & Padalinys \\
\hline Patirties partneriai (P4V) & 2014-2015 m. & URD \\
\hline GRADual: studentu/absolventų pasirengimo isidarbinti gerinimas & 2014-2016 m. & URD \\
\hline Bendradarbiavimas skatinant švietimą atstatymo po katastrofų srityje -CADRE & 2013-2016 m. & SF \\
\hline $\begin{array}{l}\text { Bendradarbiavimas atnaujinant atsparumo nelaimėms srities studiju programas, jose } \\
\text { panaudojant atvirojo kodo intelektines sistemas ir papildytają realybę - RESINT }\end{array}$ & 2013-2015 m. & SF \\
\hline Ateities mokslas ir studijos informatikoje: kaip užtikrinti mokymąsi bet kur ir bet kada - FETCH & $2013-2016 \mathrm{~m}$ & FMF \\
\hline iPro (iProfessionals, liet. profesinių kompetencijų pažangiujų kompiuterinių technologijų srityje vystymas) & 2013-2015 m. m. & SF \\
\hline Atstatymo po katastrofų akademinis tinklas, skirtas aukštojo mokslo vystymui optimizuoti - ANDROID & 2011-2014 m. & SF \\
\hline $\begin{array}{l}\text { Mobilumo ir praktikos patirtis: skatinimas keistis inovacijomis siekiant energijos taupymo ir } \\
\text { efektyvumo statybu sektoriuje - METE GREEN }\end{array}$ & $2014 \mathrm{~m}$. & SF \\
\hline Europos centras projektu / praktikų kompetencijoms - PRAXIS & $2011-2015 \mathrm{~m}$. & EF \\
\hline \multicolumn{3}{|l|}{ Erasmus Mundus programa } \\
\hline Europos ir Azijos bendradarbiavimo tinklas aplinkos apsaugos ir sveikatos srityse - PANACEA & 2012-2016 m. & URD \\
\hline Mobilumas iš Juodosios ir Kaspijos jūrų regionų - BACKIS & 2012-2016 m. & URD \\
\hline \multicolumn{3}{|l|}{ Erasmus jauniesiems verslininkams programa } \\
\hline BIZ-ON-BOARD & $2013-2015 \mathrm{~m}$ & VVF \\
\hline \multicolumn{3}{|l|}{ Erasmus Youth in Action programa } \\
\hline Būk mūsų pasaulio dalimi & $2014 \mathrm{~m}$. & URD \\
\hline \multicolumn{3}{|l|}{ Nordplus programa } \\
\hline Rytų Baltijos kraštovaizdžio architektūros mokyklų tinklas - ENBLAS & $2012-2015 \mathrm{~m}$. & $\mathrm{AF}$ \\
\hline \multicolumn{3}{|l|}{ Leonardo da Vinci programa } \\
\hline $\begin{array}{l}\text { Baltijos jūros regiono kraštovaizdžio architektų nuolatinio profesinio augimo programos perkėlimas - } \\
\text { CPD-LA }\end{array}$ & 2013-2015 m. & $\mathrm{AF}$ \\
\hline Europos bendros magistro studijos valdant statybos projektą - MBAIC & $2013-2015 \mathrm{~m}$ & SF \\
\hline $\begin{array}{l}\text { Pastatų informacinio modeliavimo mokymų irankio perkèlimas siekiant padidinti statybos } \\
\text { sektoriaus specialistų kompetencijas - BIMTRAIN }\end{array}$ & 2013-2015 m. & IKD \\
\hline GEO VET Skills Plus & $2013-2015 \mathrm{~m}$ & AIF \\
\hline Socialinė inovacija ir domotika augančioje sidabrinėje ekonomikoje: naujieji gebėjimai & $2014 \mathrm{~m}$. & URD \\
\hline \multicolumn{3}{|l|}{ TEMPUS programa } \\
\hline Automobilių pramonės ir miestụ inžinerijos studijų plètra ir tobulinimas Serbijoje - DIAUSS & $2011-2014 \mathrm{~m}$. & AIF \\
\hline $\begin{array}{l}\text { Dviejų pakopu e. komercijos programa, skirta informacijos visuomenei Rusijoje, Ukrainoje ir Izraelyje - } \\
\text { ECOMMIS }\end{array}$ & 2011-2014 m. & VVF \\
\hline Studiju programų atnaujinimas užstatytos aplinkos srityje Rytu partnerystės šalyse - CEN EAST & $2012-2015 \mathrm{~m}$. & SF \\
\hline Nepriklausomas studiju programų Rusijoje kokybės užtikrinimo modelis - IQA & $2012-2015 \mathrm{~m}$. & URD \\
\hline Verslo ir ekonomikos akademinio mokymo ir tyrimų aplinkos atnaujinimas Libane ir Sirijoje - MATRE & 2013-2016 m. & VVF \\
\hline Naujos geodezijos magistrantūros programos vystymas - MPG & $2013-2016 \mathrm{~m}$ & AlF \\
\hline $\begin{array}{l}\text { Nauju inžinerinių modulių trečiosios studijų pakopos kūrimas pagal Bolonijos procesą Baltarusijai, } \\
\text { Rusijai ir Ukrainai - NETCENG }\end{array}$ & 2013-2016 m. & AIF \\
\hline \multicolumn{3}{|l|}{ MVG/Erasmus intensyvios programos } \\
\hline $\begin{array}{l}\text { Gyvenamujų daugiabučiu pastatų renovacija pagal pasyviujų namų koncepciją ir projektus - } \\
\text { RenoPassCoDe }\end{array}$ & 2011-2014 m. & SF \\
\hline Moteru siekiai ir verslumas - FEE & $2011-2014 \mathrm{~m}$ & VVF \\
\hline Darnūs esami pastatai - SEB & $2013-2014 \mathrm{~m}$ & AIF \\
\hline Darnus nekilnojamojo turto vystymas - SRED & 2013-2014 m. & SF \\
\hline Darnus gyvenamujų pastatų atnaujinimas - SuReMaSuPi & $2013-2014 \mathrm{~m}$. & SF \\
\hline Darnus atnaujinimas, modifikavimas, energijos valdymas būstuose - SuReReEnMaHo & 2013-2014 m. & SF \\
\hline Miesto atnaujinimas: pastatų rekonstravimas pagal dabarties (ateities) reikalavimus - UrbReg & $2013-2014 \mathrm{~m}$. & SF \\
\hline Aktyvūs žaidimai & $2013-2014 \mathrm{~m}$. & EF \\
\hline Integruotų darniujų technologijų pritaikymas taikomuosiuose moksluose & 2013-2014 m. & MF \\
\hline Tarpdalykinis tyrimas tarpkultūrinèje aplinkoje - CIRCE & 2012-2014 m. & VVF \\
\hline Modernioji logistika: stiprinant verslumo igūdžius ir motyvaciją - IP MoLo & 2014 m. & VVF \\
\hline \multicolumn{3}{|l|}{ Kiti tarptautiniai studijų projektai } \\
\hline Social Face & 2014 m. & URD \\
\hline Erasmus Lietuvos mokykloms & $2014 \mathrm{~m}$. & URD \\
\hline
\end{tabular}


2014 m. i VGTU atvyko 818 studentų iš 54 pasaulio šalių. Tai rodo, kad studijos VGTU populiarèja tiek ES, tiek ne ES šalyse. Per pastaruosius ketverius metus penkis kartus padaugejo laipsnio siekiančių užsienio studentų ypač Verslo vadybos, Statybos inžinerijos ir Mechanikos fakultetuose (3.17 pav.) Toki augimą paskatino fakultetu pradètos vykdyti naujos studijų programos, kai kurios jų vykdomos ir nuotoliniu būdu.

2014 m. VGTU dalyvavo septyniose tarptautinèse studijų parodose. VGTU atstovai lankè užsienio šalių mokyklas, dalyvavo seminaruose ir konferencijoje, joje pristate studijų programas ir studijų sąlygas potencialiems studentams iš užsienio.

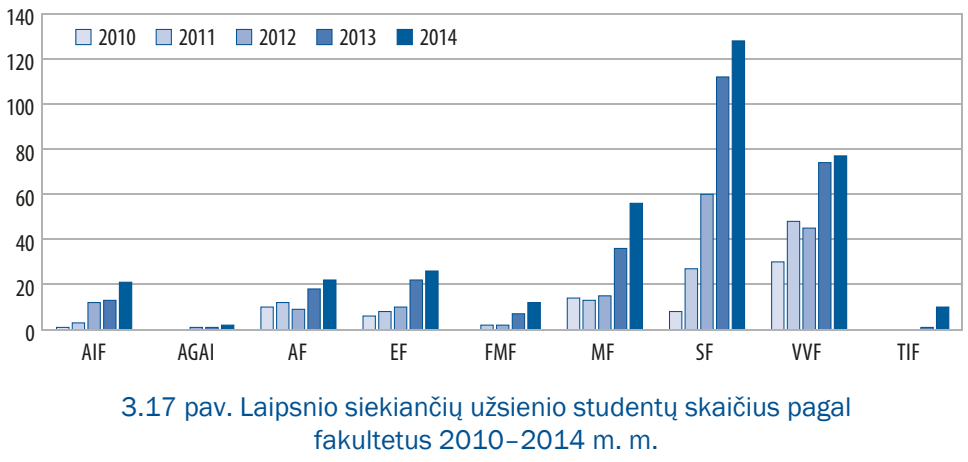

2014 m. VGTU antrus metus iš eilès prièmė Hiustono universiteto (JAV) EMBA (angl. Executive MBA) vadovų magistrantūros 32 studentų grupę. Universitetas kartu su Užsienio reikalų ir ūkio ministerijomis organizavo seminaru ciklą aukščiausio lygio vadovams, turintiems daugiau kaip septynerių metų vadovavimo patirti ir studijuojantiems verslo administravimą Hiustono universitete.

2014 m. VGTU organizavo penkių savaičių trukmės vasaros mokyklą kartu su JAV Kalifornijos valstybiniu politechnikos universitetu (CalPoly). Tai antrus metus vykdoma tarptautinè mokykla, kurioje 2014 m. daIyvavo aštuoniolika studentų iš Kalifornijos valstybinio politechnikos universiteto ir aštuoni VGTU Statybos fakulteto Architektūros inžinerijos katedros bei Tiltų ir specialiujų statinių katedros studentai. Paskaitas ir praktinius užsièmimus studentams vedè CalPoly ir VGTU dėstytojai. Išlaikę egzaminus studentai gavo po septynis ECTS kreditus.

Užsienio ryšių direkcijos koordinuojamoje SOCIAL FACE vasaros mokykloje nagrinètos tokios temos, kaip savęs pažinimas, asmeninès karjeros projektavimas, tarpkultūrinė komunikacija, kaip būti sėkmingam tarptautinėje darbo rinkoje, socialinių mediju taikymas asmeniniam prisistatymui internetinėje erdvėje ir tokiu irankių taikymas versle, asmeninių iniciatyvų ir projektų vystymas ir viešinimas. Vasaros mokyklos veiklą finansavo Švietimo mainų fondas VGTU laimèjus paraiškų konkurse.

Užsienio studentams naują aplinką pažinti padeda Erasmus studentų tinklo (toliau - ESN VGTU) veikla bei mentoriu programa, kurioje 2014 m. dalyvavo 140 VGTU studentų. Jau tradicija tapę kasmetiniai projektai „Erasmus Lietuvos mokykloms“, „Nerūkymo savaitė“, „Nebūk daiktistas“, „Erasmus miškas“, „Erasmus suoliukai“, „Balti centai“ (labdaros akcija léšoms globojamu gyvūnų maistui surinkti) įtraukè ir vietos, ir užsienio studentus. Kaip kasmet, buvo tęsiami bendruomenei skirti kalbos ir kultūros pažinimo projektai: korèjiečių, ispanų kalbos ir kultūros pamokos Multilingual Lithuania. ESN VGTU sekcija šiais metais sulaukè tarptautinio ivertinimo - buvo laimèta teisè 2014 m. gruodžio 11-14 d. organizuoti ES šalių nacionalinių delegatų konferenciją Lietuvoje, sukvietusią 120 užsienio ESN sekcijų atstovų iš 37 valstybių. Konferencijoje aptarti organizacijos valdymo, struktūros klausimai, artėjančios naujovès, aptarti ir su mobilumu ne ES šalyse susiję projektai Erasmus+ programoje. Universitetas stiprina užsienio studentų integraciją i akademini, kultūrini gyvenimą.

2014 m. ivyko iš viso 1319 VGTU darbuotojų vizitų i užsienị. Akademinis personalas vyko ị užsieni skaityti paskaitų, dalyvauti tarptautinėse konferencijose, seminaruose, mokslo projektų partnerių susitikimuose, vykdyti stažuotę.

VGTU siekia pritraukti iš užsienio dirbti universitete aukštos kvalifikacijos dėstytojus, galinčius perteikti naujausių pasaulinio lygio žinių aktualiomis studijų temomis. $2014 \mathrm{~m}$. VGTU dirbo 47 dèstytojai iš JAV, Kinijos, Taivano, Austrijos, Olandijos, Čekijos, Lenkijos, Slovėnijos, Rusijos, Ukrainos ir Vokietijos universitetų. Iš ju buvo įdarbinta septyniolika kviestinių profesorių, atvykusių skaityti paskaitu pagal LR švietimo ir mokslo ministerijos programą, kurią VGTU kofinansavo universiteto Tarptautinès plètros fondo lešomis, penki kviestiniai profesoriai skaitè paskaitas VGTU organizuotose vasaros mokyklose. Siekiama didinti kviestiniu dèstytojų indèli i studiju procesą: jų paskaitos integruojamos i VGTU dėstytojų dėstomus dalykus kartu egzaminuojant, organizuojamos atviros paskaitos. 


\subsubsection{Erasmus programa}

Mokymosi visą gyvenimą MVG / Erasmus programa yra populiariausia mainu programa. 2014 m. buvo perejjimo i Erasmus+ programą metai. Ši programa atvers universiteto bendruomenès nariams dar platesnių tarptautinių galimybių. Svarbiausias programos vykdymo iššūkis 2013-2014 m. m. buvo sumažèjęs finansavimas, lèmęs mažèjančius mobilumo rodiklius. Ši tendencija būdinga ir šalies mastu. Nors bendras studentu mobilumo skaičius sumažèjo, palyginti su 2012-2013 m. m., tačiau, analizuojant VGTU siųstinu studentų dalị nuo bendro studentų skaičiaus procentais, matyti, kad mažejimas yra nedidelis (3.18 pav.).

Daugiausia studentų (procentais) nuo siųstinų studentų skaičiaus išvyko iš Architektūros, Verslo vadybos ir Aplinkos inžinerijos fakultetu (3.19 pav.). Daugiausia studentų pagal Erasmus programą studijuoti ar atlikti praktikos išvyko i Vokietiją, Ispaniją, Portugaliją ir Italiją.

2013-2014 m. m. užsienio mainų studentų, atvykusių ilgalaikių mainų, skaičius nuo 313 padaugejo iki 386 (3.20 pav.). Pagal Erasmus programą studijuoti atvykusių studentų skaičius išaugo nuo 288 iki 325. Pagal dvišales sutartis iš P. Korejjos atvykusių studentų skaičius išliko didelis, atvykusių iš Taivano partnerių institucijų studentų padaugejjo nuo dviejų iki dešimt. Atvykstančių studentu skaičiaus augimą paskatino Erasmus Mundus programos vykdomi projektai: pagal BACKIS projektą i VGTU atvyko šešiolika studentu (BA - dvylika, MA - keturi), pagal PANACEA projektą atvyko dešimt studentų (BA - šeši, MA - trys, PhD - vienas).

Populiariausiu fakultetu VGTU, kuri renkasi atvykstantys studentai, išliko Verslo vadybos fakultetas. Šiame fakultete studijavo beveik $30 \%$ (97) visu atvykusių studentų. Antrają poziciją pagal populiarumą antrus metus iš eilès išlaiko Mechanikos fakultetas, i kuri atvyko 47 studentai. [ Architektūros ir Aplinkos inžinerijos fakultetus atvykstančiu studentų padaugèjo vienodai: 2012-2013 m. m. atitinkamai turèje 16 ir 28 studentų, 2013-2014 m. sulaukè 26 ir 38. Gerokai sumažèjo atvykusiujų j Fundamentinių mokslų fakultetą (2012-2013 m. m. - 28 studentai, 2013-2014 m. m. - 19). Dèl mažos studijų anglų kalba pasiūlos mažiausiai studentų sulaukè Transporto inžinerijos fakultetas (10) ir Antano Gustaičio aviacijos institutas (3). Padaugèjo i Elektronikos fakultetą atvykusių studentų: 2012-2013 m. m. - 28 studentai, 2013-2014 m. m. - 43 studentai. Daugiausia studentu studijuoti ir atlikti praktikos pagal Erasmus programą atvyko iš Vokietijos, Prancūzijos, Ispanijos ir Turkijos.

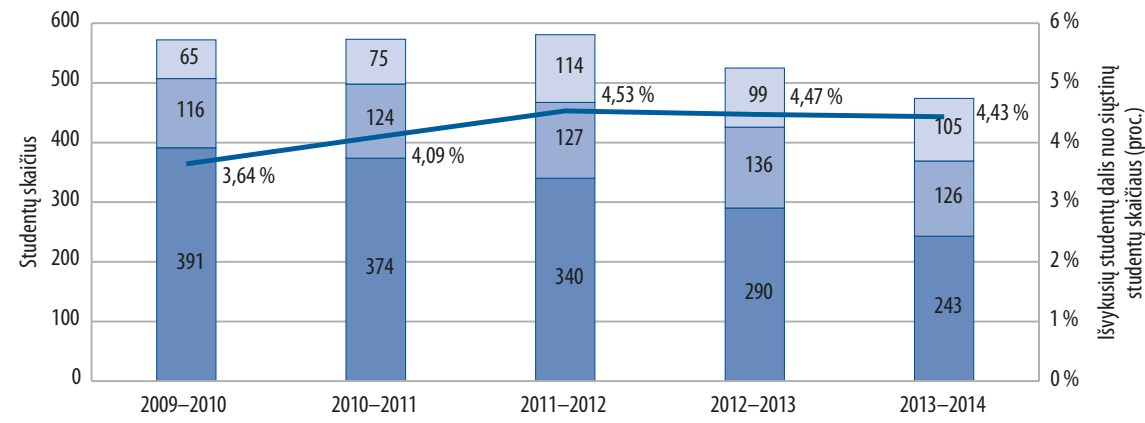

$\square$ lšrykusių studentų skaičius pagal kitas mainų programas

口 Išvykusių studentų skaičius pagal Erasmus programą atlikti praktikos

— Išvykusių studentų skaičius pagal Erasmus programą studijuoti

— Išvykusių studentų pagal mainų programas skaičius nuo bendro studentų skaičiaus (proc.)

3.18 pav. Išvykusių studentų pagal mainų programas skaičius 2009-2014 m. m.

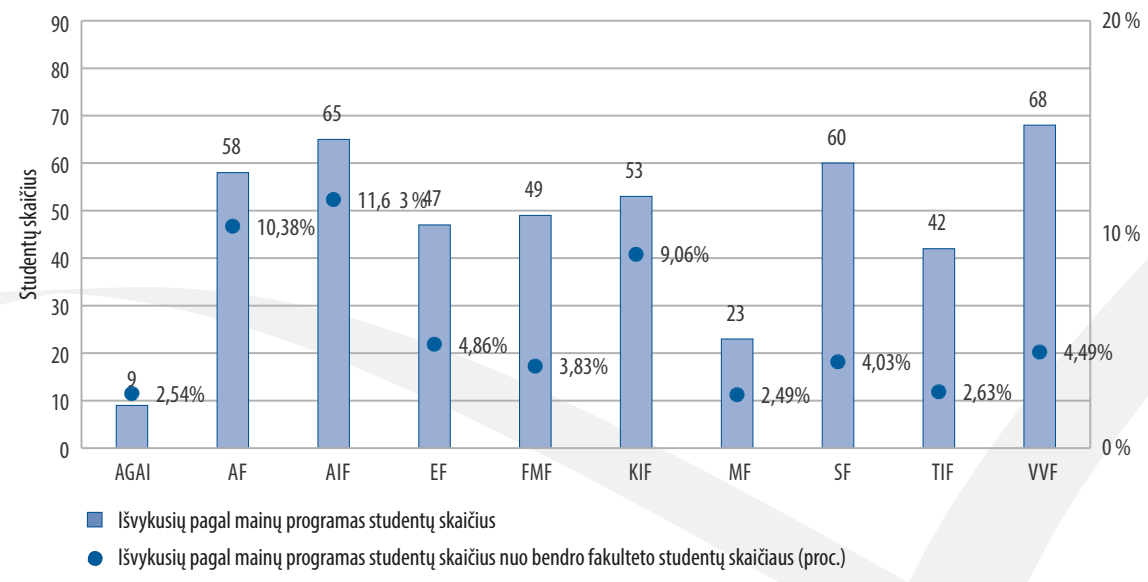

3.19 pav. Išvykusių pagal mainų programas studentų skaičius pagal fakultetus 2013-2014 m. m. 
2013-2014 m. m. darbuotojų išvykų pagal Erasmus programą padaugejo iki 196, t. y. 30,1 \% daugiau, lyginant su 2012-2013 m. m. (3.21 pav.). Ataskaitiniu laikotarpiu išvykų skaičius yra didžiausias nuo šios veiklos pradžios universitete. Padidèjusi darbuotojų aktyvumą lėmė gautas didesnis finansavimas iš nacionalinès paramos lèšų ir aktyvus programos viešinimas. Aktyviausi Erasmus mokymosi ir dèstymo vizitų dalyviai 2013-2014 m. m. buvo Statybos, Verslo vadybos ir Kūrybinių industrijų fakultetų darbuotojai. Akademinio personalo mobilumo pagal Erasmus programą pagrindinis tikslas - išvykų pridėtinè vertè darbuotojui ir universitetui. Jauni déstytojai skatinami vykti su mobilumo vizitais, kad galètų plètoti tarptautinius profesinius ryšius ir didinti tarptautinę kompetenciją.

2013-2014 m. m. pagal Erasmus programą i universitetą atvyko 98 darbuotojai iš užsienio aukštojo mokslo institucijų ir verslo įmonių, iš jų 41 atvyko skaityti paskaitų, 57 - mokymosi tikslais. Užsienio ryšių direkcijos organizuotų tarptautinių teminių darbuotojų mokymosi savaičių metu - 2014 m. gegužès ir birželio mėn. - atvyko 46 darbuotojai; pagal Erasmus programą buvo pakviesti verslo profesionalai iš devynių užsienio įmonių skaityti paskaitu ir pasidalyti geraja patirtimi su universiteto bendruomene.

2013-2014 m. m. MVG / Erasmus programai vykdyti buvo panaudota 3,58 mln. litu EK ir nacionalinès paramos lèšu (3.17 lentelè). Iš viso 77 \% gautų asignavimų skirta studentų mobilumo stipendijoms studijoms ir praktikai, $23 \%$ - personalo mobilumui dėstymo ir mokymosi tikslais. Didesnis finansavimas buvo skirtas administracijos personalo stažuotems pagal Erasmus programą. Tai leido šios veiklos rodikli padidinti net iki 51 vizito per akademinius metus (2012-2013 m. m. buvo 18 vizitų). Mobilumo veikloms organizuoti ir administruoti, palyginti su 2012-2013 m. m., buvo panaudota 90 tūkst. Lt daugiau. Tai lèmė augantis atvykstančių mainų studentų skaičius, didejjantis išvykstančių dėstytojų ir personalo narių skaičius, viešinimo priemonių užtikrinimas ir sklaida.

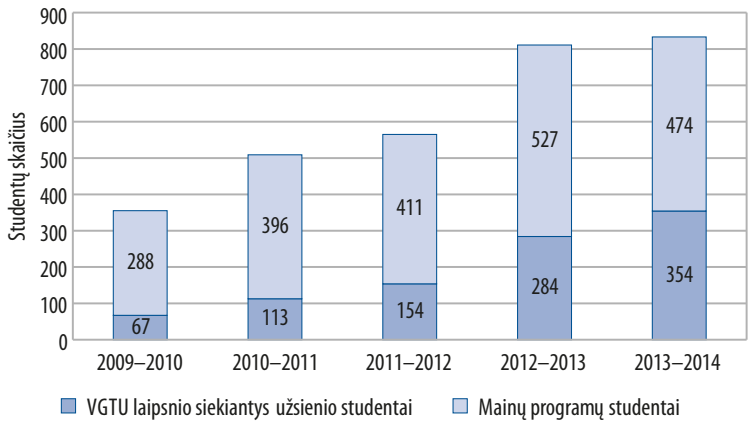

3.20 pav. Užsienio studentų, atvykusių studijuoti, skaičius 2009-2014 m. m.

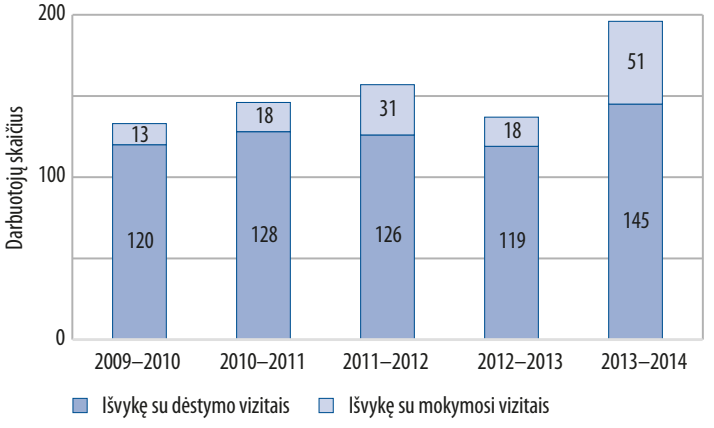

3.21 pav. VGTU personalas, išvykęs trumpalaikiu mainu pagal Erasmus programą 2009-2014 m. m.

3.17 lentelè. Erasmus programos veikloms panaudota parama 2013-2014 m.

\begin{tabular}{|c|c|c|c|}
\hline Veikla & EK parama, Lt & Nacionalinè parama, Lt & Iš viso programai skirta, Lt \\
\hline Studentų praktikų mobilumas & 694317 & 34224 & 728541 \\
\hline Personalo dėstymo mobilumas & 188532 & 201440 & 389972 \\
\hline Personalo mokymosi mobilumas & 62866 & 102400 & 165266 \\
\hline Iš viso & 2570368 & 1012423 & 3582391 \\
\hline
\end{tabular}

Svarbi mobilumo ir užsienio studentų priėmimo studijoms VGTU laipsniui gauti sąlyga - 2013 m. patvirtinto Studijų programų užsienio kalba plètros koncepcijos plano igyvendinimas. Erasmus Mundus programos projektų vykdymas yra svarbus naujoms mainų kryptims ir institucinėms partnerystėms. Kviestiniams dėstytojams pritraukti i VGTU studijų procesą bus mobilizuojamos URD ir fakultetų pastangos bei skiriamos Tarptautinès plètros fondo lèšos.

VGTU 2013-2015 m. strateginio veiklos plano kontekste vertinant 2013-2014 m. rezultatus, išryškèja šie svarbiausi studijų tarptautiškumo plètros uždaviniai: pagerinti studentų ir dėstytojų mobilumo rodiklius, užtikrinti ne mažiau kaip 4,5 \% išvykstamaji mobilumą nuo bendro VGTU studentu skaičiaus, siekti, kad mainų ir laipsnio siekiančių užsienio studentų daugètų - 2017 m. sudarytų atitinkamai po 5 \% VGTU studentų. 


\subsection{Studentų karjera ir ịsidarbinimas}

Europos Sajungos ir nacionaliniai dokumentai (Lisabonos strategija, Europos aukštojo mokslo kokybės užtikrinimo nuostatos ir gairès, „Europa 2020“, „Lietuvos pažangos strategija 2030“ ir kt.) akcentuoja glaudų universitetų ryši su aplinka, kurioje absolventai rengiami veikti, pabrėžia sąlygu, padedančių sėkmingai studentų integracijai i darbo rinką, sukūrimą. Lietuvoje jaunimo nedarbo rodiklis 2014 m. pabaigoje buvo 17,5 \%. 2014 m. Europos Sajungos šaliu jaunimo iki 25 metu nedarbo vidurkis yra 21,6 \%. Vertinant absolventu isidarbinimą, 2014 m. sausio-lapkričio mèn. i Lietuvos darbo biržą dèl darbo paieškos kreipèsi 16,4 tūkst. absolventų, atitinkamu laikotarpiu 2013 m. - 20,7 tūkst. Absolventu dalis tarp per laikotarpi registruotu jaunu bedarbių iki 25 metu amžiaus 2014 m. sausio-lapkričio mèn. sudarè 30,7 \%.

Vilniaus Gedimino technikos universiteto Integracijos ir karjeros direkcija, nuolat tobulindama studentu informavimo ir karjeros konsultavimo sistemą, inicijavo ir igyvendino ivairius projektus, padedančius studentams planuoti, projektuoti savo karjerą bei sėkmingai įsitvirtinti darbo rinkoje. 2014 m. svarbiausi organizuoti renginiai bei inicijuoti projektai:

„VGTU karjeros dienos“ - 1,5 mèn. trukęs renginys, kurio metu vyko ivairių mokymų, praktinių užsièmimų, apimančių ugdymo karjerai, karjeros konsultavimo, karjeros vertinimo ir karjeros galimybiu pažinimo temas. Surengtos verslo lyderių paskaitos ir praktiniai užsièmimai, imitaciniai darbo pokalbiai, kontaktų mugè ir vizitai i i imones. Renginiuose dalyvavo daugiau nei 2500 VGTU studentų ir 44 įmonès.

„VGTU absolventai: 100 perspektyvų 2014“ - tęstinis projektas renkant perspektyviausius metų absolventus iš visų fakultetų. Išleistas elektroninis leidinys, kuriame pristatomi šie absolventai, jiems surengti neuroligvistinio programavimo mokymai.

„Susitik su Integracijos ir karjeros direkcija“ - 2 akademinių val. ìvadinis paskaitų ciklas visų fakultetų pirmo kurso studentams (rugsejjo-spalio mėn.) siekiant užtikrinti kryptingą naujų studentų ir nuoseklią veiklą universitete karjeros ugdymo kontekste.

„Pažink profesiją“ - birželio 30 d. - liepos 5 d. dienomis suorganizuota antroji VGTU vasaros stovykla moksleiviams, kuri skatina atsakingai ir apgalvotai pasirinkti studijas. Sudarytos galimybės pažinti ịvairias studiju sritis - aplinkosaugą, mechaniką, techniką, inžineriją ir kūrybines industrijas. 2014 m. stovykloje dalyvavo 36 moksleiviai iš Lietuvos mokyklų ir gimnazijų, lietuvių vaikai iš užsienio.

„Misija: karjera“ - naujas Vilniaus Gedimino technikos universiteto, Kauno technologijos universiteto ir Lietuvos pramonininkų konfederacijos inicijuotas moksleivių orientavimo projektas. 2014 m. pasirašyta jungtinès veiklos sutartis ir sukurta internetinė platforma www.misijakarjera.It.

Surengtas asmeninio efektyvumo mokymų ciklas VGTU studentams. Mokymų metu buvo nagrinèjamos šios temos: „Kaip per trumpesnį laiką padvigubinti asmeninį rezultatyvumą?“, „Darbo paieška ir suradimas: sèkmès programavimas ir pavojų išvengimas“, „Kaip padaryti gerą i̇spūdị per darbo pokalbị?“

Bendradarbiaujant kartu su WIX.com surengtos atviros paskaitos informacinių technologiju studentams Elektronikos fakultete ir Fundamentinių mokslų fakultete. Paskaitos transliuotos tiesiogiai internetu.

VGTU Tarptautinių studijų centro studentams surengta atvira paskaita „Karjera: iššūkiai ir galimybės“ apie Integracijos ir karjeros direkcijos teikiamas paslaugas VGTU studijuojantiems užsienio studentams: karjeros konsultacijas, pagalba ieškant darbo ar praktikos vietos, i̇sidarbinimo procesą užsieniečiams Lietuvoje, CV rengimą ir kt. Užsienio ir lietuviams studentams suorganizuota paskaita apie i̊darbinimą ir atrankas tarptautinėse kompanijose bei jų organizavimo praktiką anglų kalba.

Plètojant karjeros valdymo informacinę sistemą (KVIS) VGTU Integracijos ir karjeros direkcijos paslaugos studentams ir verslo organizacijoms idiegtos naujame vgtu.It tinklalapyje. Skelbiama informacija apie organizuojamus renginius ir projektus, teikiami darbo ir praktikos skelbimai. l̨diegta elektroninè registracija karjeros konsultacijoms, kurios suskirstytos i keturias pakopas: savęs pažinimo; CV ir motyvacinio laiško parengimo; darbo paieškos strategijų kūrimo; pasiruošimo darbo pokalbiui.

Integracijos ir karjeros direkcija siekia palaikyti ryši su studentais, todèl dalijasi aktualiausia informacija Facebook socialiniame tinkle. Studentai nuolat informuojami ir konsultuojami el. paštu, individualiai karjeros konsultacijų metu ir grupèse.

Universitetas, remdamasis Lietuvos darbo biržos duomenimis, kiekvienais metais atlieka absolventu isidarbinimo analizę. Lietuvos darbo biržoje registruotu šalies aukštuju mokyklų absolventu skaičius siekia 10,8 \%, VGTU absolventu dalis nuo visų šalies aukštujų mokyklu absolventų - 4,8 \%, VGTU absolventų dalis nuo LDB registruotu jaunų bedarbių (iki 25 metų) sudaro 1 \%. Lietuvos darbo birža yra sudariusi jaunojo bedarbio portretą, pagal kuri dalis, turinti aukštaji išsilavinimą, siekia 21,1 \% nuo visu jaunuju bedarbiu skaičiaus. Sugretinus Lietuvos darbo biržos ir statistinius VGTU 2014-aisiais metais baigusių absolventų duomenis, ivertintas ịsidarbinimas pagal fakultetus. Didžiausi ịsidarbinimo rodikliai priklauso Architektūros (97 \%), Statybos (96 \%) ir 
Aplinkos inžinerijos (93 \%) fakultetams. Apibendrinant visus rezultatus galima teigti, kad absolventu isidarbinimo rodikliai yra teigiami. Pagrindiniai veiksniai, lemiantys absolventų i̊sidarbinimą, yra šie: asmeninės savybės, socialiniai ryšiai, darbo patirtis ir tai, kad studijavo būtent VGTU.

Integracijos ir karjeros direkcija bendradarbiauja su darbdaviais ir studentams reguliariai atnaujina darbo ir praktikos skelbimų duomenų bazę. Remiantis statistiniais duomenimis, $2014 \mathrm{~m}$. gautų skelbimų studentams skaičius padidejo $30 \%$, t. y. 504 darbo ir praktikos skelbimai.

Darbo ir praktikos skelbimai suklasifikuoti pagal karjeros kryptis. Paklausiausios karjeros kryptys, remiantis darbo skelbimų skaičiumi, 2013 ir 2014 m. išlieka tos pačios. Tą pati patvirtina ir praktikos skelbimu statistiniai duomenys. Didžiausios paklausos sulaukusios karjeros kryptys 2014 m. pagal Integracijos ir karjeros direkcijos duomenų bazèje registruotas darbdavių užklausas darbui ir praktikai buvo informacinès technologijos ir telekomunikacijos, statybos, architektūros, nekilnojamojo turto, transportavimo ir logistikos. 


\section{Moksliniai tyrimai ir inovacijos}
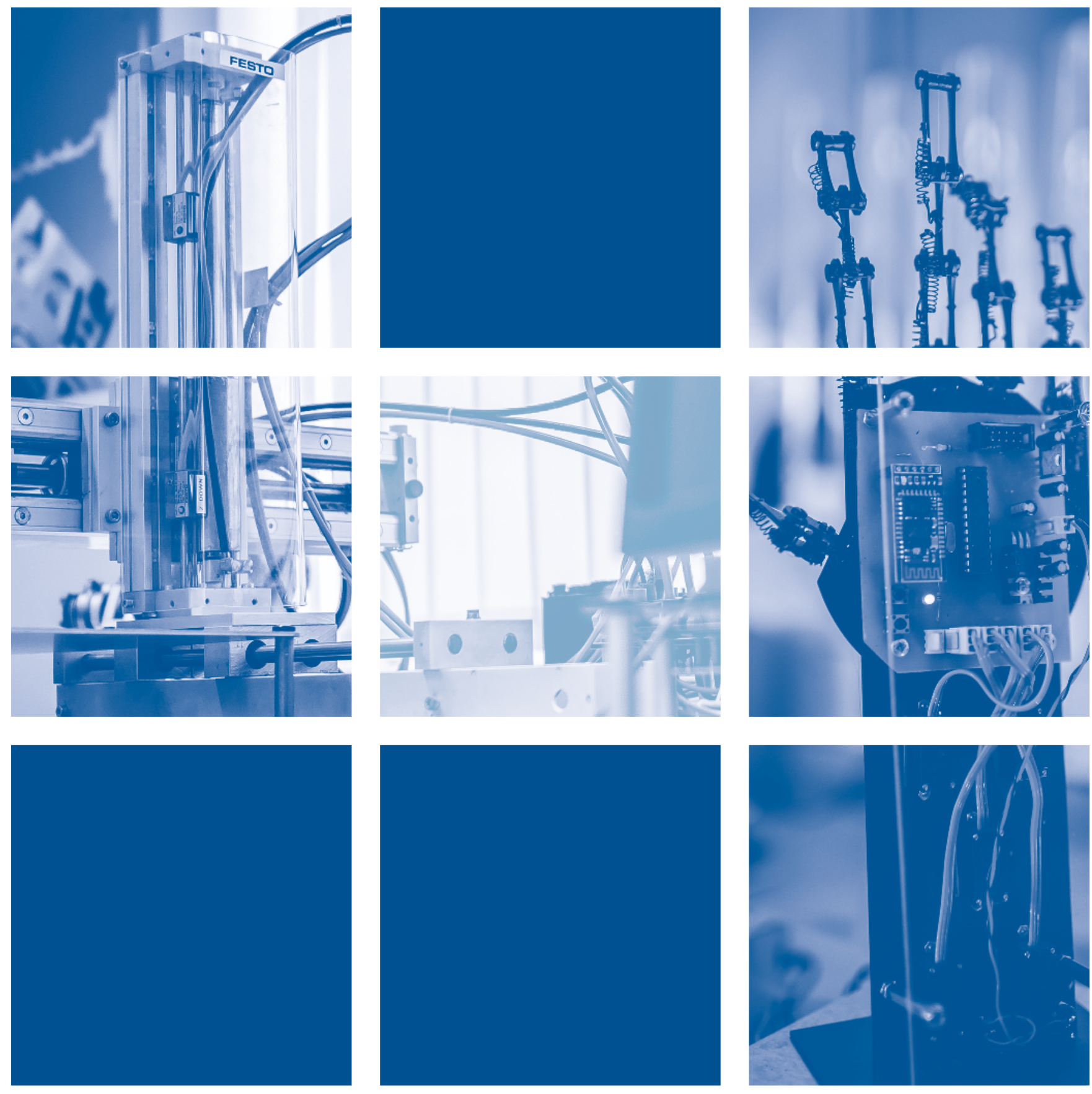



\section{Moksliniai tyrimai ir inovacijos}

VGTU vykdo aktualių mokslo sričių mokslinius tyrimus ir eksperimentinès (socialinès, kultūrinès) plètros (toliau - MTEP) darbus tiek nacionaliniu, tiek tarptautiniu lygmeniu. Atliekamu darbu tematikos ir sukaupta patirtis tiesiogiai atitinka keturias iš šešių 2013 m. spalio 14 d. LR Vyriausybès nutarimu Nr. 951 patvirtintas prioritetines MTEP ir inovaciju raidos (sumanios specializacijos) kryptis: energetika ir tvari aplinka; itrauki ir kūrybinga visuomenè; nauji gamybos procesai, medžiagos ir technologijos; transportas, logistika ir informacinès ir ryšių technologijos.

Esame išskirtiniai regiono mastu vykdomais statybinių medžiagų ir konstrukcijų, termoizoliacinių medžiagu, akustikos notifikuotais ir akredituotais tyrimais, transporto ir logistikos tyrimais. Universiteto mokslininkai prisideda prie šalies ūkio raidos vykdydami statinių ir konstrukcijų, kelių, geodezijos ir kadastro, teritorijų planavimo, pastatų energinio vertinimo, energijos aprūpinimo sistemų, aplinkosaugos inžinerijos, termoizoliacinių karščiui atsparių medžiagų, nekilnojamojo turto vadybos, informacinių technologijų saugos, architektūros, urbanistikos, kraštovaizdžio architektūros ir bioinžinerijos tyrimus.

\subsection{Mokslo ir technologijų prioritetai ir plètra $2014 \mathrm{~m}$.}

Moksliniai tyrimai - svarbi universiteto veiklos sritis, lemianti aukštesni studijų lyğ ir padedanti valstybei spręsti aktualias technologines, ekonomines ir socialines problemas. Žiniomis grịsta inovatyvi ekonomika tampa prioritetiniu Lietuvos siekiu. Moksliniai tyrimai ir jų rezultatų skleidimas studijų procese būtinas ugdant išsilavinusią, gebančią kurti ir taikyti naujausias žinias bei technologijas asmenybę. Siekiant šių tikslų svarbus vaidmuo ir didelè atsakomybė tenka universitetui - vieninteliam technologinio profilio universitetui Vilniaus regione.

Universiteto mokslo strategijos kryptys - koncentruoti prioritetinių mokslinių tyrimų krypčių kuriant palankią aplinką mokslinei kūrybai ir tarpdisciplininei mokslininkų kooperacijai bei plètoti mokslinès veiklos tarptautiškumą ir dermę su Europos tyrimu erdvès prioritetais. Svarbiausi su moksline veikla susiję uždaviniai:

- Vykdyti tarptautinio lygio aktualių prioritetinių mokslo vystymo krypčių MTEP darbus.

- Sutelkti žmogiškuosius, finansinius ir administracinius išteklius sukuriant stambius tyrimų centrus.

- Koncentruoti VGTU mokslininkų ir tyrèju potencialą i tarpkryptinius tyrimus, orientuotus i didelę šalies pridètinès vertès dali sukuriančius ūkio sektorius.

- Inicijuoti ir vykdyti ilgalaikius kompleksinius tarptautinius ir nacionalinius MTEP darbus.

- Skatinti kurti naujas technologijas ir jas komercializuoti.

- Ugdyti studentų kūrybiškumą ir verslumą.

Universiteto stiprybė - galimybė konkrečiai problemai spręsti pasitelkti įvairiausių sričių mokslininkus, pradedant fundamentaliujų mokslų atstovais, sudarant stiprią taikomujų mokslų atstovų komandą kartu su informaciniu technologijų, vadybos, rinkodaros ir net menų krypties mokslininkais.

Universitetas bendradarbiauja su daugiau nei 100 partnerių, tarp kurių - tiek žinomiausios Lietuvos, tiek tarptautinès įmonès.

Universiteto prioritetinės mokslinių tyrimų kryptys buvo suformuluotos siekiant koncentruoti mokslini potencialą ir efektyviai įsilieti ¡̨ Europos mokslinių tyrimų erdvę. Jos jungia skirtingų mokslo krypčių mokslininkus tarpkryptiniams ir tarpdalykiniams tyrimams (4.1 lentelè).

Numatytiems strateginiams tikslams pasiekti VGTU nuolat analizuoja mokslinès veiklos rezultatus ir koncentruoja žmogiškuosius išteklius, skatina mokslinės veiklos tarpdalykiškumą ir mokslininkų kolektyvų susibūrimą kompleksiniams projektams vykdyti. 
4.1 lentelè. Mokslinių veiklų dažniausias pasiskirstymas pagal VGTU prioritetines mokslo kryptis

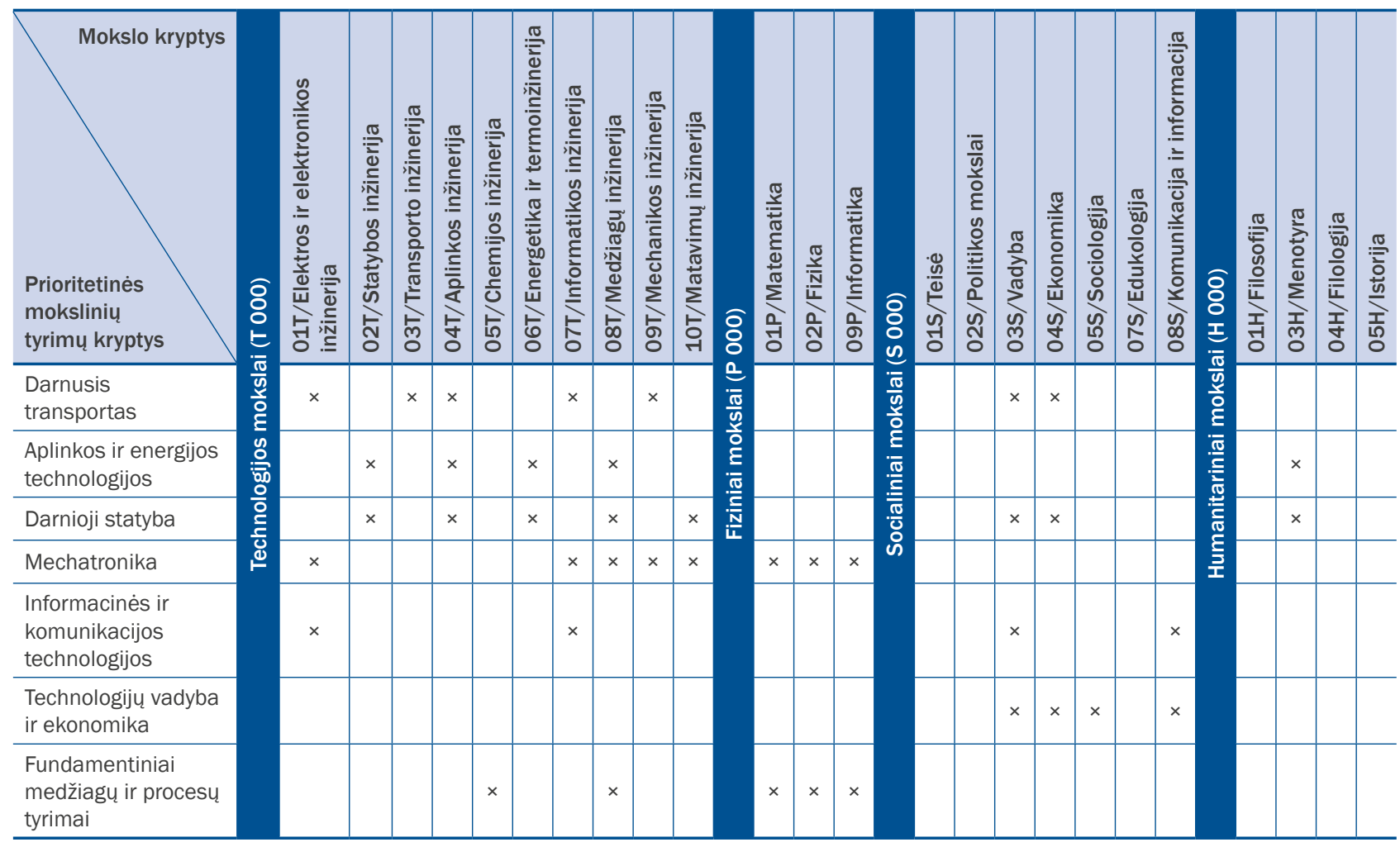

Atsižvelgiant i įnovatyvių metodų taikymo poreikị statybu sektoriuje, $2014 \mathrm{~m}$. gegužès 13 d. VGTU ịkurtas Statinių informacinio modeliavimo technologijų centras (SIMTC). SIMTC misija - sukurti stiprų regionini Skaitmeninès statybos (angl. BIM) technologiju plètros ir vystymo centrą Lietuvoje ir Baltijos šalyse, atstovaujantị architektūros ir statybos inžinerijos, transporto ir infrastruktūros inžinerijos sritims, kuriame nuolat kaupiamų teorinių žinių lygis paremtų praktinių igūdžių ugdymo ir profesinès kvalifikacijos tobulinimo procesus, plètojant tvirtą mokslo ir verslo ryši, bei gerintų inovacijų ciklą statybos pramonès srityje.

2014 m. VGTU profesorius Gintaris Kaklauskas buvo apdovanotas Lietuvos mokslo premija už svarbiausius fundamentinius ir taikomuosius bei eksperimentinès plètros darbus technologijos mokslų srityje - inovatyvų ir statybų praktikoje reikšmingą armuotojo betono tyrimų ciklą.

2014 m. VGTU naujai gavo teisę rengti aplinkos inžinerijos krypties mokslo daktarus.

2014 m. prasidèjo nauji nacionalinių ir tarptautinių programų etapai. Tai didelis iššūkis tiksliniam universiteto mokslinès veiklos finansavimui. Siekdamas sėkmingai dalyvauti konkursinio finansavimo projektuose, universitetas strategiškai koncentruoja savo veiklą i septynias prioritetinių mokslinių tyrimų kryptis. Formuojant nacionalinio konkursinio finansavimo programų kvietimus universiteto mokslininkai aktyviai dalyvauja sudarant šešių Lietuvos prioritetinių MTEP ir inovacijų raidos krypčiu programas (VGTU atstovai yra dviejų krypčių ekspertinių grupių vadovai, penkių krypčių - nariai).

2014 m. septyniolika (2013 m. - dvylika) VGTU mokslininkų $h$ indeksas buvo didesni už 10 .

Universiteto vykdomų taikomujų tyrimų konkurencingumą ir paklausą iliustruoja lěšos, gautos vykdant mokslinių tyrimų ir taikomosios plètros bei su moksline veikla susijusius paslaugu darbus (4.1 pav.). 2014 m. iš ūkio subjektu, tarptautinių ir nacionaliniu mokslo programų buvo gauta $11,37 \mathrm{mln}$. Lt. Tai dvigubai daugiau nei tiesioginiai valstybès asignavimai MTEP veiklai.

Papildoma bazinio finansavimo dalis buvo skiriama ūkio subjektų užsakymais vykdomiems moksliniams tyrimams remti, 2014 m. VGTU buvo skirta 453 tūkst. Lt. 


\subsection{Mokslo pasiekimai ir inovacijos}

\section{Tarptautiniai ir šalies mokslinių tyrimų projektai}

Universiteto mokslinès veiklos plètra yra nuosekliai orientuota bei susijusi su Nacionalinès darnaus vystymosi strategijos ekonomikos, aplinkos kokybès ir socialinio vystymosi kryptimis. Platus universiteto mokslinès veiklos spektras yra labai palankus igyvendinant tarpkryptinių, tarpdalykinių tyrimų Europos moksliniu tyrimu erdvèje skatinimo nuostatas, suformuluotas programoje „Horizontas 2020“. VGTU mokslinių tyrimų veiklos glaudžiai siejasi su keturiomis iš šešių šios programos sričių: saugi, švari ir veiksmingai naudojama energija; išmanus, netaršus ir integruotas transportas; klimato veikimas, išteklių efektyvumas ir žaliavos; integruota, novatoriška ir saugi visuomenè.

2014 m. universiteto mokslininkai vykdè dvidešimt du tarptautinius mokslo projektus: vienuolika iš ju ES 7 BP, du - Eureka, vienas - COST ir šeši kitų programų projektų (4.2 lentelè).

2014 m. VGTU mokslininkai ir toliau dalyvavo Eureka ir COST programu projektuose. Šios programos laikomos didesnių 7BP projektų inkubatoriumi. $2013 \mathrm{~m}$. VGTU Elektronikos fakulteto mokslininkai, vadovaujami dr. A. Medeišio, sėkmingai užbaigè COST programos informacinių technologijų srities veiklos IC0905 „Sumanios radijo sistemos ir perprogramuojamos radijo sistemos: techninis ir ekonominis reguliavimas bei radijo spektro valdymas“ (Techno-Economic Regulatory Framework for Radio Spectrum Access for Cognitive Radio/Software Defined Radio, TERRA) koordinavimą. Tai pirmas atvejis, kai patvirtinta Lietuvos mokslininku inicijuota programos COST veikla. Taip pat universiteto mokslininkai atstovauja Lietuvai net aštuonių COST veiklų valdymo komitetuose.

Informacija apie 2014 m. VGTU vykdytus tarptautinius mokslo projektus pateikiama 4.2 pav. ir 4.2 lentelèje.

4.2 lentelè. 2013 m. VGTU vykdyti tarptautiniai projektai

\begin{tabular}{|c|c|}
\hline \multicolumn{2}{|l|}{ EUROPOS KOMISIJOS PROGRAMOSE: 7-oji bendroji programa (7 BP) } \\
\hline $\begin{array}{l}\text { Gyvenimo kokybès gerinimas ES vystant darnu } \mathrm{CO}_{2} \text { neutralių EKO miestų plètrą (ECO-Life). SF, T. Vilutienė; } \\
\text { APF, V. Martinaitis }\end{array}$ & $2009-2015$ \\
\hline Aviacijos triukšmo tyrimų tinklas ir koordinavimas (X-Noise EV). TII, A. Jagniatinskis & 2010-2014 \\
\hline Europos ir Azijos geležinkelių mokslinių tyrimų kompetencijos tinklas (NEAR2). TIF, G. Bureika & 2012-2014 \\
\hline E. jūru transporto strategijos gairès ir simuliacija grindžiamas igalinimas (eMar). TIF, A. Šakalys & 2012-2015 \\
\hline $\begin{array}{l}\text { Novatoriškų medžiagu sprendimai transporto, energijos ir biomedicinos srityse, sustiprinant integraciją ir } \\
\text { didinant KMM-VIN tyrimų dinamiką (INNVIN). FMF, R. Kačianauskas }\end{array}$ & 2012-2015 \\
\hline Gerosios praktikos erdvè krovininiam transportui (BESTFACT). TIF, A. Šakalys & 2012-2015 \\
\hline Platus plieninių konstrukcijụ tvermès norminimas (LVS3). SF, A. K. Kvedaras & 2013-2014 \\
\hline $\begin{array}{l}\text { Bendri veiksmai socialiniu uždavinių sprendimui per sąmoningumą, sklaidą ir švietimą (CASCADE). } \\
\text { SF, A. Kaklauskas }\end{array}$ & 2013-2015 \\
\hline Rytu ir Vakaru sujungimas tyrimams aeronautikos ir kosmoso srityse (BEWARE). AGAI, L. Mašnauskas & 2013-2015 \\
\hline Tvarus žmogiškujų ištekliu vystymas Viduržemio jūros šalyse (SHuMED). VVF, M. Tvaronavičienè & 2014-2015 \\
\hline $\begin{array}{l}\text { Energijos tyrimai inovacijoms: bendradarbiavimo su partnerystès šalimis stiprinimas, siejant tyrimus su } \\
\text { inovacijomis (ENER2i). ARF, G. Stauskis }\end{array}$ & 2014-2016 \\
\hline \multicolumn{2}{|l|}{ EUREKA } \\
\hline $\begin{array}{l}\text { Galios kabelių matematinis modeliavimas ir optimizavimas jų projektavimo metodikoms tobulinti } \\
\text { (POWEROPT, E! 6799). FMF, R. Čiegis }\end{array}$ & 2012-2015 \\
\hline $\begin{array}{l}\text { Iš technogeniniu atlieku sukurti nekenksmingus aplinkai cementinius kompozitus ir ju gamybos technologijas } \\
\text { (Enclosurewasteconcrete, E! 8790). TII, M. Sinica }\end{array}$ & 2014-2016 \\
\hline \multicolumn{2}{|l|}{ COST } \\
\hline $\begin{array}{l}\text { Sumanios radijo sistemos ir perprogramuojamos radijo sistemos: techninis ir ekonominis reguliavimas bei } \\
\text { radijo spektro valdymas (COST ICO905). EF, A. Medeišis }\end{array}$ & 2010-2014 \\
\hline \multicolumn{2}{|l|}{ KITOS EUROPOS KOMISIJOS PROGRAMOS } \\
\hline Daugiausia energijos sutaupantys studentai (SAVES). SF, A. Kaklauskas & 2014-2017 \\
\hline $\begin{array}{l}\text { Lietuvos statybos sektoriaus specialistu mokymu ir kvalifikacijos kèlimo iniciatyva, siekiant nacionaliniu } \\
\text { lygmeniu didinti pastatu ir statinių energini efektyvumą (Buil Up Skills ENERGOTRAIN). SF, T. Vilutienė }\end{array}$ & 2014-2016 \\
\hline \multicolumn{2}{|l|}{ KITOS PROGRAMOS } \\
\hline Espon raiška Šiaurès Europos šaliu kontekste (ENECON). TPMI, M. Burinskienè & $2012-2014$ \\
\hline $\begin{array}{l}\text { BSR TransGovernance - MLG parama igyvendinant PA } 11 \text { (PA transportas) (BSR TransGovernance). } \\
\text { TIF, R. Palšaitis }\end{array}$ & 2012-2014 \\
\hline $\begin{array}{l}\text { Parengto Lietuvos Longlife projekto igyvendinimas statant Klaipèdos universiteto bendrabuti } \\
\text { (Longlife Invest). SF, J. Parasonis }\end{array}$ & 2013-2014 \\
\hline $\begin{array}{l}\text { Europos teritorinès plètros ir sanglaudos stebejjimo tinklo rezultatų taikymas (ESPONontheROAD). } \\
\text { APF, M. Burinskienè }\end{array}$ & 2014 \\
\hline
\end{tabular}


4.3 pav. pateikiama informacija, kaip 2014 m. tarptautinėse mokslo programose dalyvavo VGTU fakultetai ir mokslo padaliniai pagal vykdytu projektų skaičių ir gautas lėšas. Iš projektų gaunamos lèšos dažnai vèluoja, todèl iš vykdomų projektų skaičiaus ne visada galima spręsti apie gautas lèšas.

Siekiant numatytų tikslų, vienas iš mokslinès veiklos prioritetų yra nacionalinių ir tarptautinių mokslo programų finansavimo galimybių diversifikavimas. Analizuojant nacionalinio konkursinio finansavimo projektus, išskirtini informatikos, elektros ir elektronikos, medžiagų, matavimų krypčių mokslininkų pasiekimai nacionalinio konkursinio finansavimo projektuose.

VGTU mokslininkų dalyvavimas nacionalinio konkursinio finansavimo projektuose pavaizduotas 4.3 lenteleje.

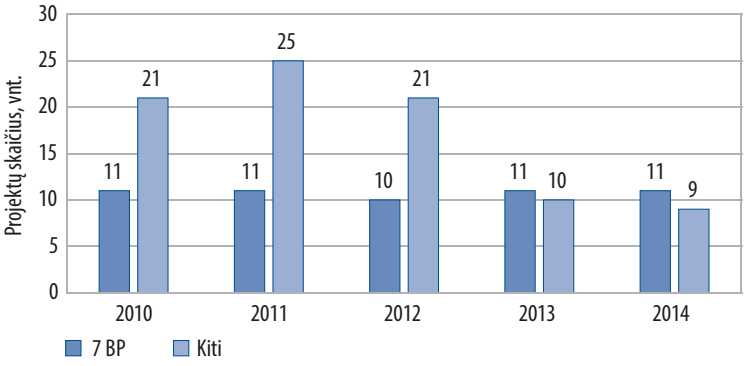

4.2 pav. VGTU vykdytu tarptautinių projektų skaičius 2010-2014 m.

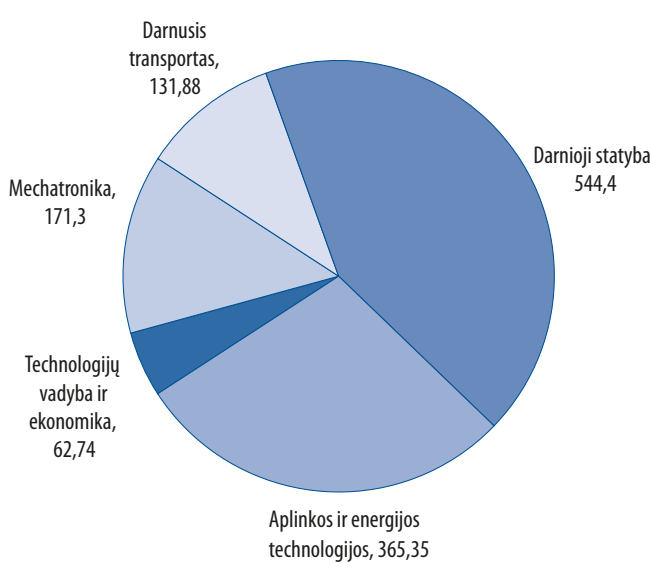

4.3 pav. VGTU vykdytų tarptautinių mokslo programų projektų skaičius ir 2014 m. gautos lèšos (tūkst. Lt)

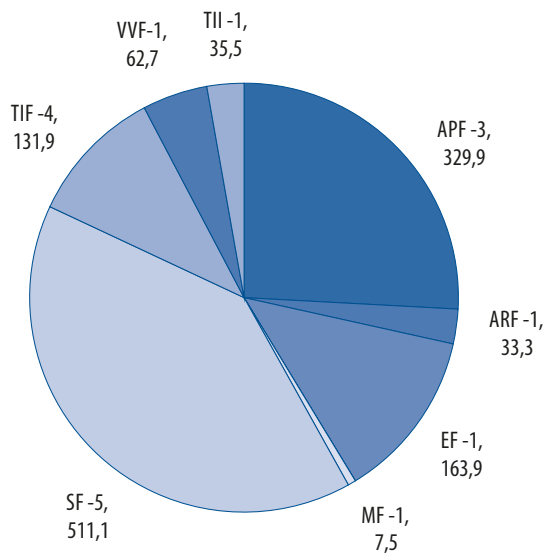

4.4 pav. Vykdytų tarptautinių mokslo programų projektų 2014 m. gautos lèšos pagal prioritetines VGTU mokslo kryptis (tūkst. Lt)

4.3 lentelè. 2014 m. Lietuvos mokslo Tarybos bei Mokslo, inovaciju ir technologiju agentūros finansuojami projektai

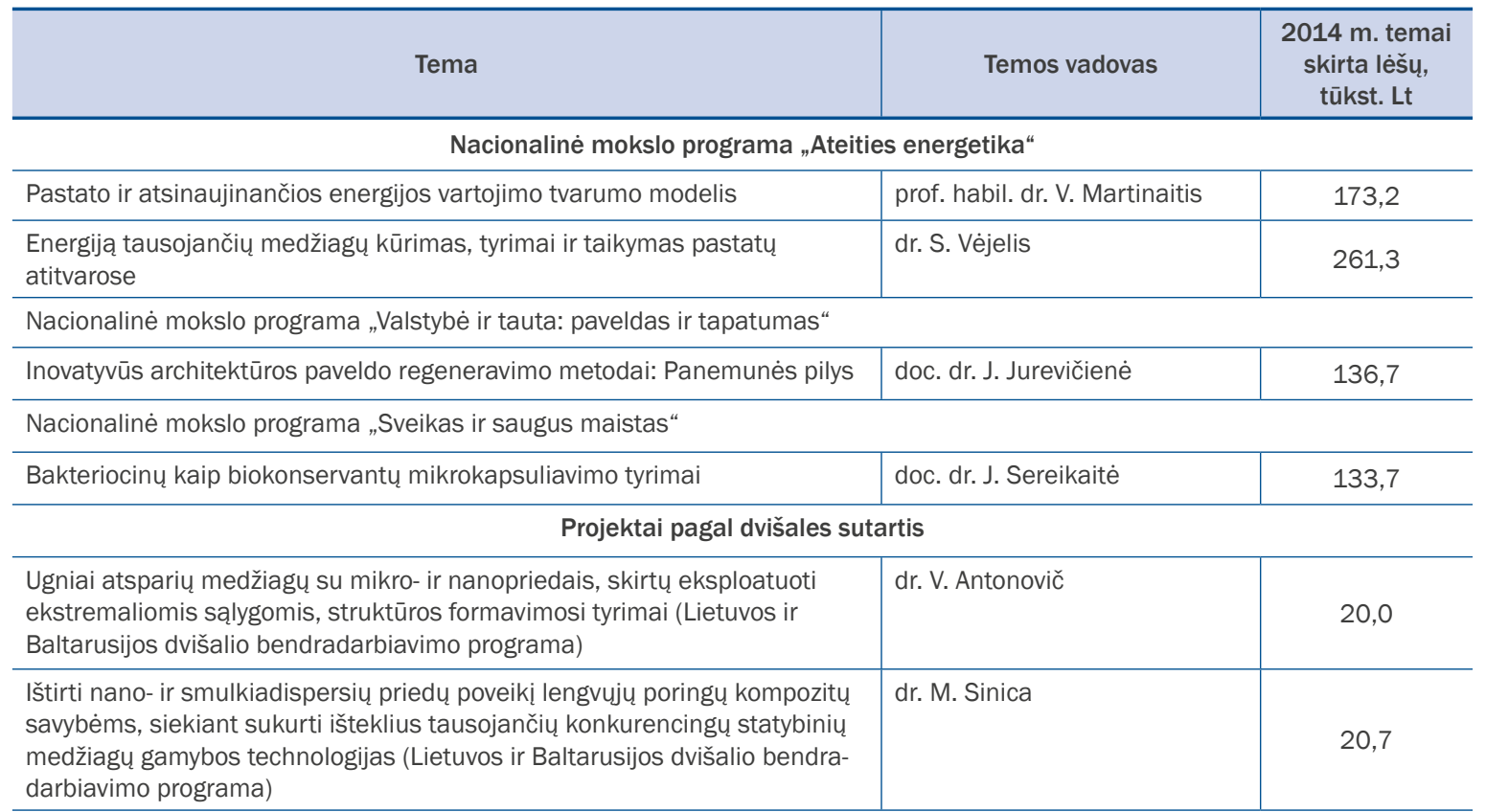


4.3 lentelès pabaiga

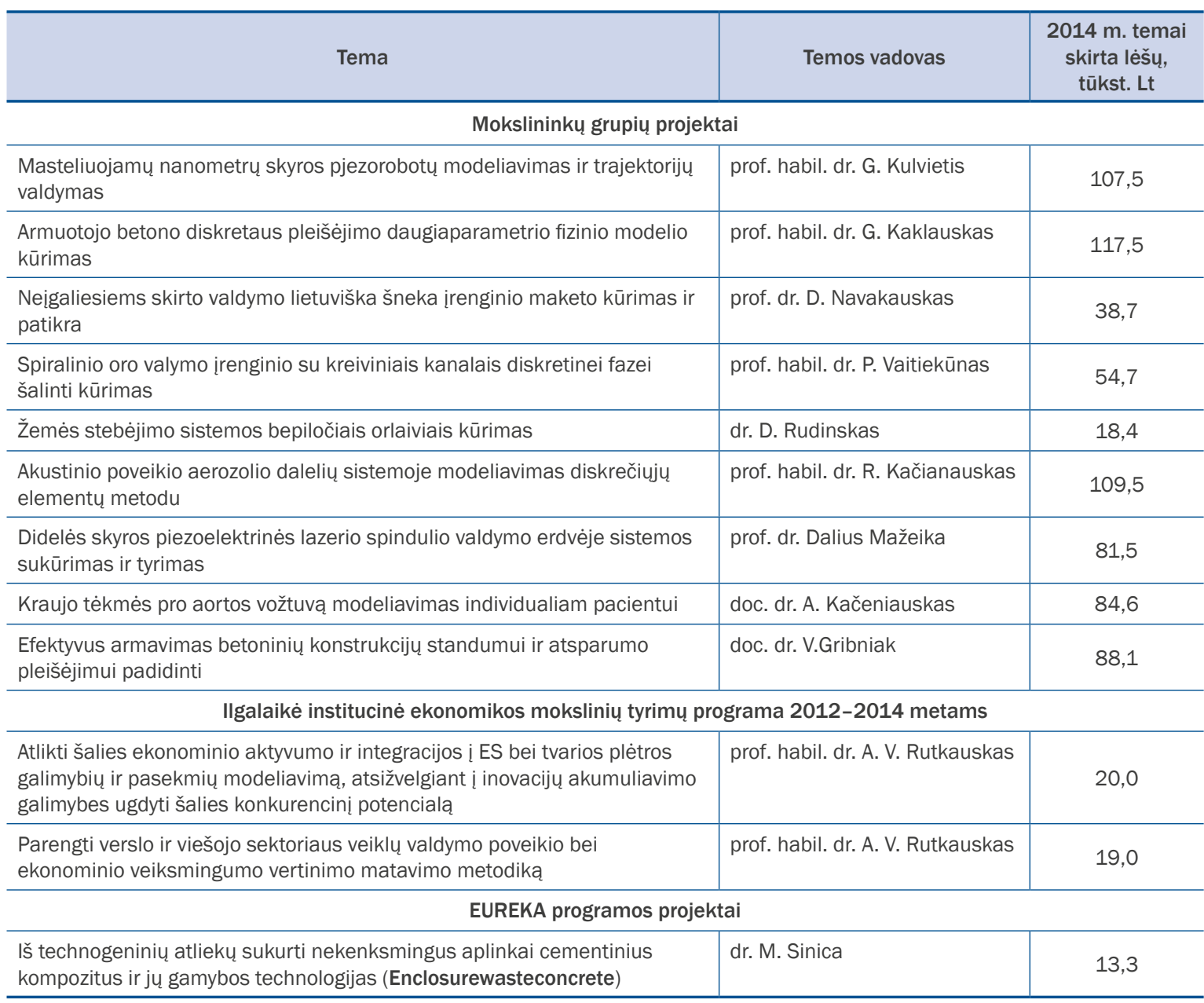

Fundamentinių ir taikomujų tyrimų dermè yra principinė VGTU mokslinès veiklos plètros nuostata, ryškus taikomasis tyrimų pobūdis būdingas technologiniams universitetams. Šiuo metu konkursini MTEP finansavimą administruoja Lietuvos mokslo Taryba (toliai - LMT) ir Mokslo, inovaciju ir technologiju agentūra (toliau - MITA). Nacionalinio konkursinio finansavimo projektuose, administruojamose LMT, 2014 m. gauta $1,49 \mathrm{mln}$. Lt.

\section{Eksperimentinès plètros darbai ir paslaugos}

Ryškiausias VGTU indėlis i šalies gerovę yra valstybės, verslo ar kitu socialiniu partnerių užsakymu atliekami mokslo tyrimai ir užsakomieji darbai. Universitetas, siekdamas plètros strategijoje numatytų tikslų, vykdo MTEP paslaugas, kurių užsakovai yra įmonės, veikiančios didžiausią šalies BVP dalị kuriančiuose sektoriuose (statybos, transporto bei logistikos ir kt.).

Pagal VGTU fakultetuose atliktų užsakomujų darbų apimtis (iskaitant fakultetų ir katedrų mokslo padalinius, 4.4 lentelè), daugiausia užsakomuju darbų atliko Aplinkos inžinerijos fakultetas (6,49 mln. Lt). Šio fakulteto mokslo padaliniai (Automobilių kelių mokslo laboratorija, Aplinkos apsaugos institutas, Geodezijos mokslo institutas, Kelių tyrimo institutas) gerai žinomi Lietuvoje ir užsienyje. Aktyviai 2014 m. su ūkio subjektais bendradarbiavo Statybos, Mechanikos bei Elektronikos fakulteto mokslininkai.

Mokslo padaliniuose aktyviausi $2014 \mathrm{~m}$. buvo Kelių tyrimo (3,43 mln. Lt), Geodezijos (2,34 mln. Lt), Termoizoliacijos mokslo (701,8 tūkst. Lt), Aplinkos apsaugos (454,48 tūkst. Lt), Teritorijų planavimo mokslo (258,8 tūkst. Lt) institutai bei Taikomoji statinių, konstrukcijų ir medžiagų laboratorija (387,92 tūkst. Lt). Kituose mokslo padaliniuose darbų apimtis buvo nedidelè.

Užsakomujų darbu struktūra pagal finansavimo šaltinius parodyta 4.5 pav. Didžiausią užsakymų dali 2014 m. sudarè valstybinès institucijos ir ịstaigos - 51 \% (2013 m. - 44 \%). Verslo subjektų užsakymuose reikia išskirti darbus pagal priemonę „Inočekiai LT“. Tai nauja Europos Sajungos struktūrinių fondu paramos priemonè, kurią nuo 2012 m. administruoja MITA. Šios priemonès tikslas - didinti šalies ūkio konkurencingumą, verslo produktyvumą ir aukštos pridètinès vertès verslo lyginamają dali, skatinti smulkiojo ir vidutinio verslo subjektus vykdyti inovacinę veiklą, skatinti mokslo ir verslo bendradarbiavimą. VGTU 2014 m. atliko pagal šią 
priemonę 142,87 tūkst. Lt vertès užsakymų, 2013 m. - už 727,37 tūkst. Lt. Sumažèjusią apimtị lèmè tai, kad 2014 m. kvietimas pagal priemonę „Inočekiai LT“ buvo paskelbtas antroje metu pusèje ir dauguma sutarčių, sudarytu su įmonèmis, baigsis $2015 \mathrm{~m}$.

Mokslo direkcija vykdo informacijos sklaidą apie VGTU mokslo padaliniu atliekamus fundamentinius ir taikomuosius tyrimus, inžinerines paslaugas ir konsultacijas VGTU žiniatinklyje bei jvairiuose renginiuose. Sėkmingam užsakomujų darbų vykdymui itin svarbūs tiesioginiai vykdytojų ryšiai su potencialiais užsakovais.

Užsakomujų darbų apimtis pagal VGTU prioritetines mokslo kryptis pavaizduotos 4.6 pav.

4.4 lentelè. Užsakomujų darbų ir paslaugų apimtis $2014 \mathrm{~m}$.

\begin{tabular}{|c|c|c|c|c|c|c|c|}
\hline \multirow[b]{2}{*}{ Padaliniai } & \multicolumn{7}{|c|}{ Atlikta darbų, tūkst. Lt } \\
\hline & 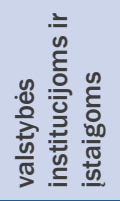 & $\begin{array}{l}\text { है } \\
\frac{n}{0} \\
\frac{0}{2} \\
\frac{0}{\pi} \\
\sum_{\pi}^{\pi}\end{array}$ & 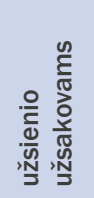 & 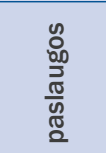 & 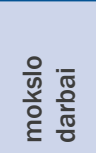 & 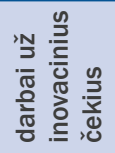 & iš viso \\
\hline Aplinkos inžinerijos & 4297,2 & 575,9 & & 1242,0 & 356,5 & 19,4 & 6491,0 \\
\hline Architektūros & & 2,9 & 4,8 & & & & 7,7 \\
\hline Elektronikos & 4,0 & & & 9,4 & 184,9 & 16,9 & 215,3 \\
\hline Fundamentinių mokslų & & & 58,4 & 39,7 & & & 98,1 \\
\hline Transporto inžinerijos & 11,0 & & 0,6 & 15,9 & 59,3 & & 86,8 \\
\hline Verslo vadybos & & & & & 10,0 & & 10,0 \\
\hline Aviacijos institutas & & & & & & & 0,0 \\
\hline \multicolumn{8}{|c|}{ Mokslo institutai } \\
\hline Termoizoliacijos & 34,0 & 0,3 & 299,7 & 265,8 & 102,0 & & 701,8 \\
\hline \multicolumn{8}{|c|}{ Mokslo centrai } \\
\hline Civilinès inžinerijos & & & & 12,2 & 19,5 & & 31,7 \\
\hline
\end{tabular}

Pastaba. Užsakomujų darbų ir paslaugų apimtis patvirtinta atliktų darbų perdavimo ir priėmimo aktais.

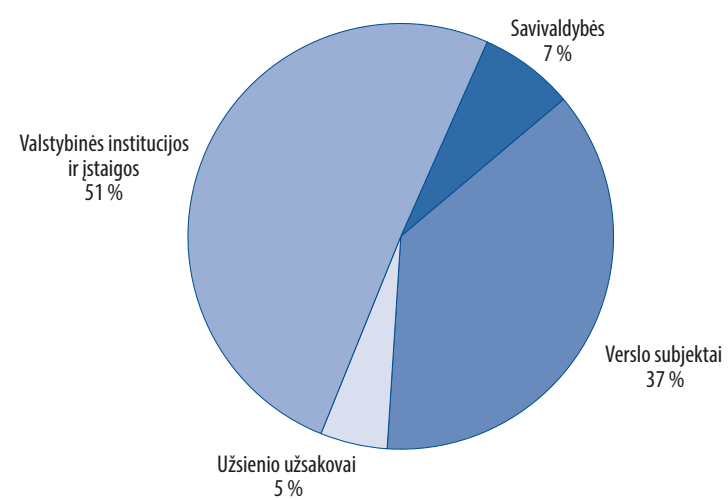

4.5 pav. Užsakomujų darbų finansavimo šaltiniai

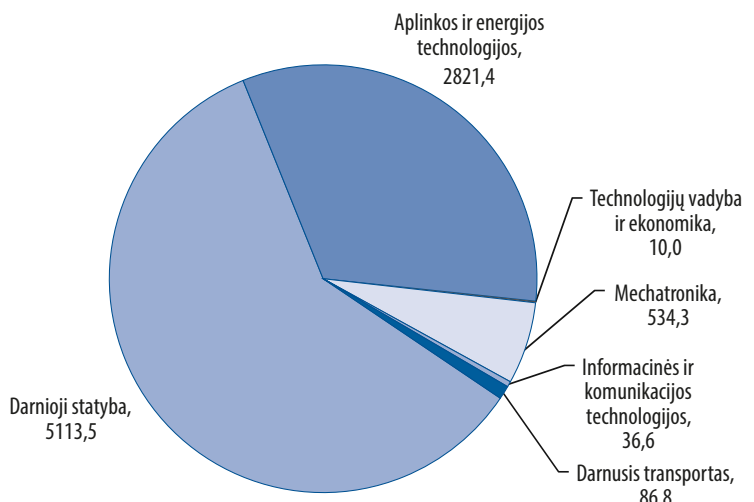

4.6 pav. Užsakomuju darbų apimtis VGTU pagal prioritetines mokslo kryptis (tūkst. Lt) 


\section{Mokslinès publikacijos ir konferencijos}

Publikacijų svarbos akcentavimas ir komunikacijos su akademine bendruomene gerinimas lèmé bendro mokslinių straipsnių skaičiaus padidejjimą 2014 m. (4.7 pav.), o ypač VGTU mokslininkų publikacijų užsienio mokslo žurnaluose, referuojamuose Tomson Reuters Web of Knowledge duomenų bazejje Web of Science ir turinčiuose citavimo indeksą: 2012 m. - 77, 2013 m. - 105, 2014 m. - 121. Bendras publikacijų skaičius, ịrašytų i Thomson Reuters Web of Science duomenu bazes, kito nedaug.

Straipsnių, ivertinus VGTU mokslininkų indèlị, periodiniuose leidiniuose, ỉrašytuose i Thomson Reuters Web of Science duomenų bazes, ir šių bazių leidiniuose, turinčiuose citavimo rodikli, skaičiai pagal fakultetus ir universitetinius mokslo padalinius pateikiami 4.8 ir 4.9 pav. Daugiausia straipsniu leidiniuose su citavimo rodikliu 2014 m. paskelbè Statybos fakulteto mokslininkai - 43, Aplinkos inžinerijos fakulteto mokslininkai - 29, Elektronikos fakulteto mokslininkai - 24.

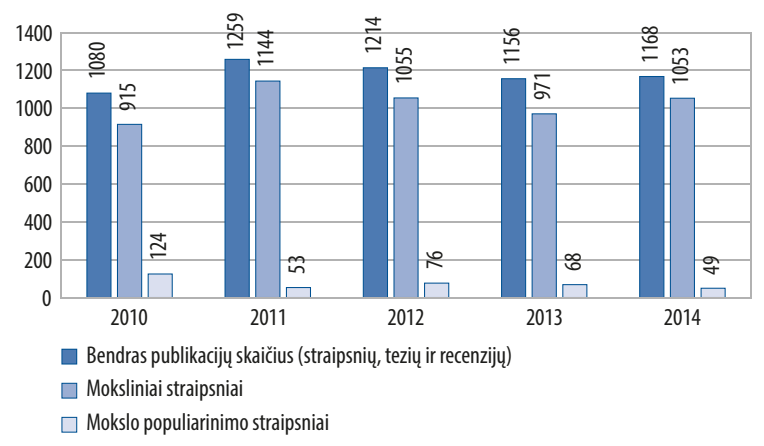

4.7 pav. Straipsnių skaičius 2010-2014 m.

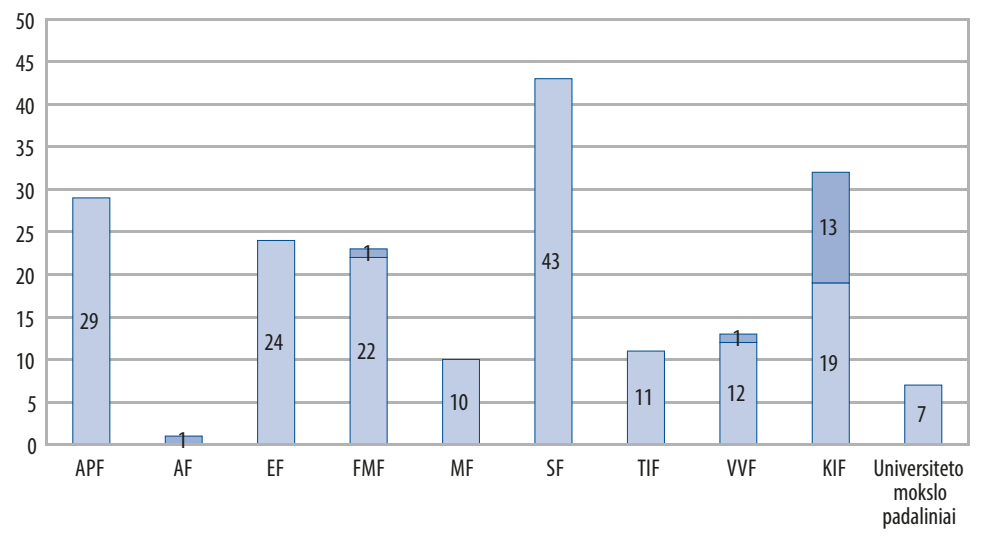

4.8 pav. 2014 m. paskelbti straipsniai periodiniuose leidiniuose, irašytuose i Thomson Reuters Web of Knowledge Web of Science duomenu bazes

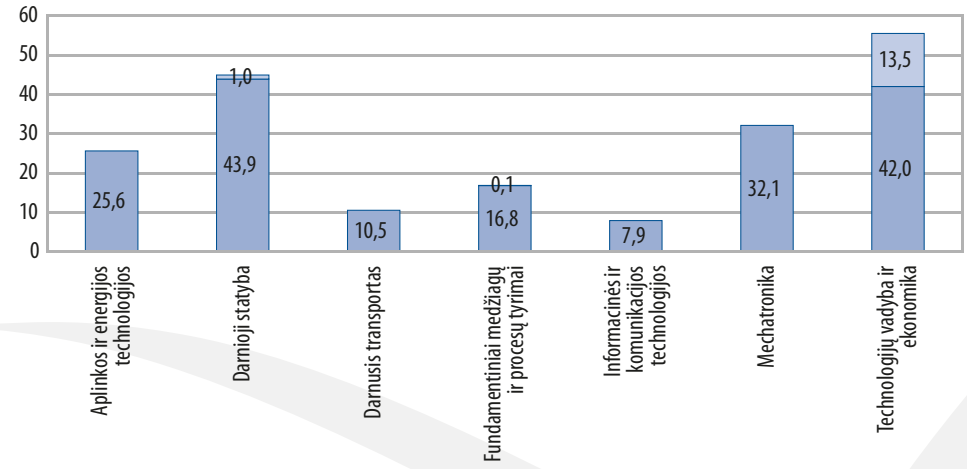

$\square$ Straipsniai Thomson Reuters Web of Science duomen ų bazių periodiniuose leidiniuose be citavimo rodiklio

$\square$ Straipsniai Thomson Reuters Web of Science duomen ų bazių periodiniuose leidiniuose su citavimo rodikliu

4.9 pav. 2014 m. paskelbti straipsniai periodiniuose leidiniuose, irašytuose i Thomson Reuters Web of Knowledge Web of Science duomenų bazes, atitinkantys VGTU prioritetines mokslo kryptis 
4.10 pav. pateikti 2014 m. straipsnių, ịvertinus VGTU mokslininkų indèlį, periodiniuose leidiniuose, įrašytuose i Thomson Reuters Web of Science duomenų bazes, skaičiai, tenkantys vienam universiteto mokslininko etatui (daktaro mokslo laipsni turintys asmenys) fakultetuose ir universitetiniuose mokslo padaliniuose. Universiteto metinis šių straipsnių vidurkis vienam mokslininko etatui per pastaruosius penkerius metus yra 0,40 straipsnio. Deja, kai kurių universiteto fakultetų, kuriuose vyrauja FBT mokslu publikacijos, 2014 m. rezultatai nesiekia universiteto metinio pastaruju penkerių metų vidurkio.

2014 m. paskelbtų straipsnių, pranešimų, tezių ir recenzijų skaičiai pagal jų rūšis fakultetuose ir universiteto mokslo padaliniuose pateikti 4.5 lentelèje.

2014 m. universiteto vardu paskelbta penkiolika monografijų, viena studija ir du mokslo šaltinių leidiniai. Per pastaruosius penkerius metus fakultetų ir universiteto mokslo padalinių autorių indèlis paskelbtose monografijose pateiktas 4.11 pav. Didžiausią indèli sudarè Verslo vadybos fakulteto mokslininkai. Rengiant monografijas prioritetas teikiamas užsienio kalba parengtoms ir tarptautinėse užsienio leidyklose leidžiamoms VGTU mokslininkų monografijoms.

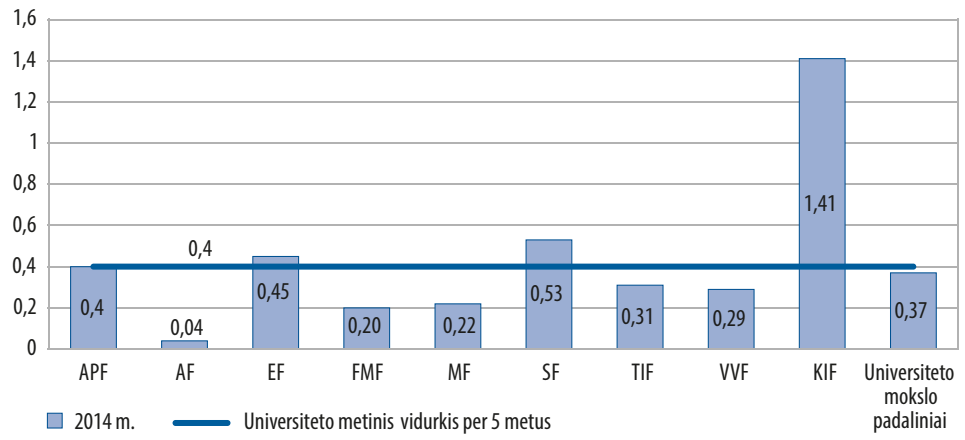

4.10 pav. Straipsniai periodiniuose leidiniuose, irašytuose i Thomson Reuters Web of Knowledge Web of Science duomenų bazę vienam mokslininko etatui

4.5 lentelè. 2014 m. paskelbti straipsniai pagal jų rūšis fakultetuose ir universiteto mokslo padaliniuose

\begin{tabular}{|c|c|c|c|c|c|c|c|c|c|}
\hline $\begin{array}{l}\text { Fakultetas, } \\
\text { padalinys }\end{array}$ & \multicolumn{4}{|c|}{$\begin{array}{l}\text { Straipsniai mokslo žurnaluose } \\
\text { ir leidiniuose }\end{array}$} & \multicolumn{3}{|c|}{$\begin{array}{l}\text { Paskelbti konferencijų } \\
\text { pranešimai }\end{array}$} & $\begin{array}{l}\text { Tezès ir } \\
\text { recenzijos }\end{array}$ & $\begin{array}{l}\text { Bendras } \\
\text { straipsnių } \\
\text { tezių ir } \\
\text { recenzijų } \\
\text { skaičius }\end{array}$ \\
\hline $\begin{array}{l}\text { Fundamentinių } \\
\text { mokslų }\end{array}$ & 22,6 & 15,8 & 3,6 & 1,0 & 7,7 & 35,9 & & 15,6 & 102,2 \\
\hline Mechanikos & 9,9 & 25,4 & 2,6 & 0,3 & 0,6 & 12,5 & 3,8 & 10,9 & 66,0 \\
\hline Statybos & 43,1 & 19,8 & 18,8 & 14,7 & 4,5 & 54,3 & 0,8 & 13,0 & 169,0 \\
\hline Transporto inžinerijos & 11,0 & 11,3 & 6,3 & 0,5 & 4,5 & 42,6 & 0,5 & 3,4 & 80,1 \\
\hline Verslo vadybos & 13,0 & 70,6 & 13,3 & & 0,5 & 118,8 & 1,3 & 5,3 & 222,8 \\
\hline $\begin{array}{l}\text { Antano Gustaičio } \\
\text { aviacijos institutas }\end{array}$ & 0,1 & 0,7 & 31,1 & 1,0 & & 0,4 & & & 33,3 \\
\hline Iš viso VGTU & 193,2 & 234,7 & 97,6 & 48,7 & 102,7 & 414,7 & 10,0 & 66,2 & 1167,8 \\
\hline
\end{tabular}


Vykdomų mokslinių tyrimų rezultatų aktualumą, svarbą ir sklaidą iliustruoja universiteto organizuojamos konferencijos.

2014 m. universitetas organizavo 22 konferencijas, šešias iš ju - tarptautines. Konferencijose dalyvavo 2205 dalyviai. Perskaityta 1240 pranešimų, iš ju 793 pranešimus perskaitè universiteto atstovai, 103 - dalyviai iš kitų Lietuvos institucijų ir 344 - dalyvių iš užsienio. Kasmet vidutiniškai organizuojamos šešios tarptautinès, penkios respublikinès ir penkiolika jaunujų mokslininkų konferencijų. Daugiausia tarptautinių konferencijų organizuota 2009 m. - vienuolika, o 2013 m. - aštuonios.

Didžiausia dalyvių ir daugiausia skaitytų pranešimų skaičiumi 2014 m. buvo 9-oji tarptautinè konferencija „Aplinkos inžinerija“. Taip pat daug dalyvių atvyko i 8-ają tarptautinę konferenciją „Verslas ir vadyba 2014“ ir 3-iają tarptautinę konferenciją „Šiuolaikinès verslo, vadybos ir studiju problemos 2014“.

VGTU sudaromos sąlygos visų pakopų studentams dalyvauti mokslinėje veikloje, taip ugdant tyrèjų gebėjimus ir skatinant rinktis mokslinę karjerą. Jau septyniolika metų VGTU organizuoja jaunujų mokslininkų konferencijų ciklą. Visų mokslo krypčių jaunieji mokslininkai (ne tik iš VGTU, bet ir iš kitu Lietuvos ir užsienio universitetų) turi galimybę publikuoti savo tyrimų rezultatus VGTU leidžiamame žurnale "Mokslas - Lietuvos ateitis“, referuojamame tarptautinèse duomenų bazèse.

Mokslo direkcija kaip ir kasmet organizavo Lietuvos jaunujų mokslininkų konferencijos „Mokslas - Lietuvos ateitis“ 2014 metų teminių konferencijų ciklo plenarini posėdị, kuriame pranešimus skaito žymūs Lietuvos mokslininkai ir verslininkai.

Dvi VGTU organizuojamos tarptautinės konferencijos gavo Lietuvos mokslo Tarybos paramą.

2010-2014 m. organizuotų konferencijų skaičiaus dinamika pavaizduota 4.12 pav.

Tradicinėmis tapusių universiteto tarptautinių konferenciju „Aplinkos inžinerija“, „Verslas ir vadyba“ rinktiniai pranešimų leidiniai įtraukiami i Thomson Reuters Proceedings duomenų bazę. 2014 m. organizuotų dviejų tarptautinių konferencijų pranešimai publikuoti konferencijų pranešimų leidiniuose.

VGTU organizuojamos konferencijos, ne tik tarptautinès, bet ir Jaunujų mokslininkų, sulaukia daug užsienio šalių dalyviu - $2014 \mathrm{~m}$. ju buvo net 581.

2013 m. VGTU organizuotose konferencijose buvo perskaityti 1206 pranešimai, o 2014 m. - 1240 (4.13 pav.). Pranešimų padaugèjo dèl suorganizuotos 9-osios tarptautinès konferencijos „Aplinkos inžinerija“, daugiau pranešimų buvo perskaityta ir JM konferencijose.

Organizuoti mokslines konferencijas ir publikuoti konferencijų leidiniuose skaitytus pranešimus neskatina šiuo metu šalyje galiojančios mokslinès veiklos vertinimo tvarkos ir ivairių konkursinio finansavimo priemonių taisyklès.

Detalesnè informacija apie 2014 m. universiteto organizuotas konferencijos pateikta 4.6-4.8 lentelèse.

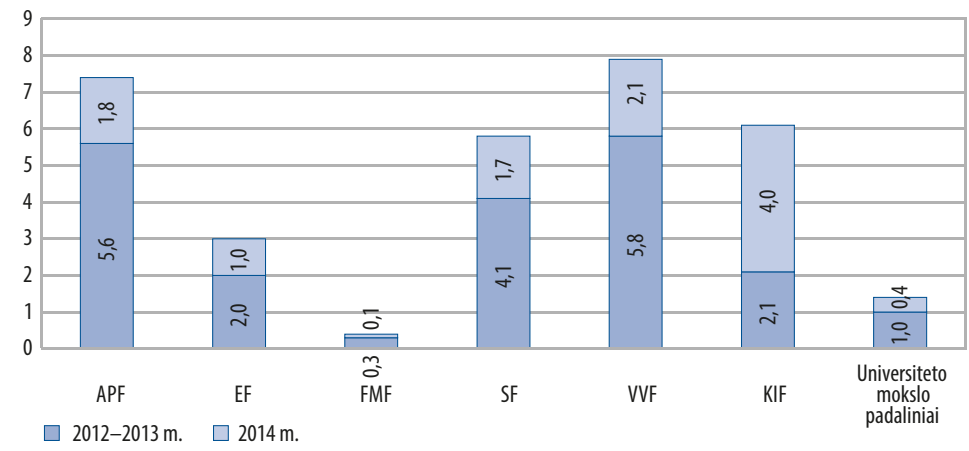

4.11 pav. VGTU mokslininku autorių indèlis paskelbtose monografijose per pastaruosius penkerius metus fakultetuose ir universitetiniuose mokslo padaliniuose

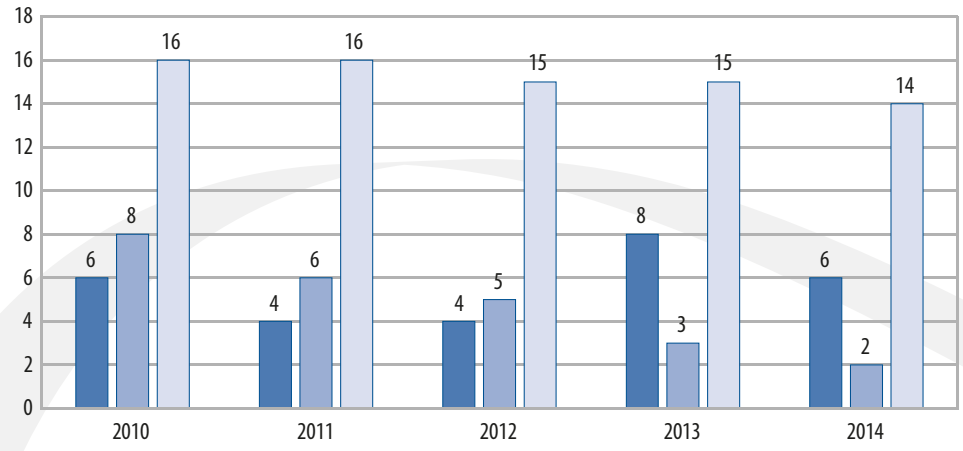

$\square$ Tarptautines $\square$ Respublikiness $\square$ Jaunujų mokslininku

4.12 pav. 2010-2014 m. organizuotos konferencijos

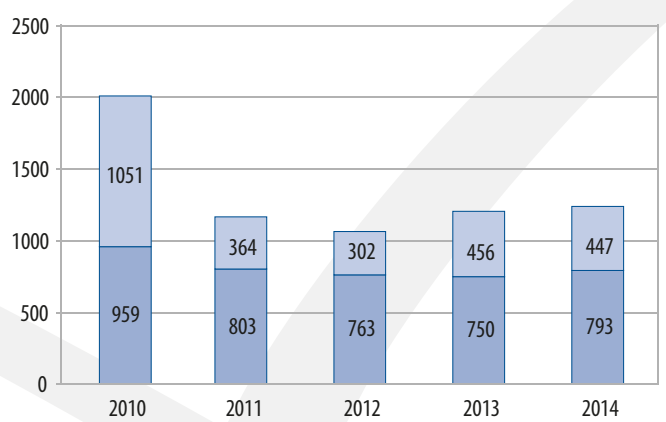

$\square$ VGTU atstovų pranešimai $\square$ Kitų institucijų atstovų pranešimai

4.13 pav. 2010-2014 m. skaityti pranešimai VGTU organizuotose konferencijose 
4.6 lentelè. Tarptautinès konferencijos $2014 \mathrm{~m}$.

\begin{tabular}{|c|c|c|c|c|c|}
\hline Renginys & Data & \multicolumn{2}{|c|}{ Dalyvių skaičius } & \multicolumn{2}{|c|}{ Pranešimų skaičius } \\
\hline $\begin{array}{l}\text { 8-oji tarptautinè mokslinè konferencija „Verslas ir } \\
\text { vadyba } 2014 \text { “ }\end{array}$ & Gegužès 15-16 d. & 250 & 136 & 77 & 36 \\
\hline 9-oji tarptautinė konferencija „Aplinkos inžinerija“ & Gegužès 22-23 d. & 324 & 150 & 262 & 135 \\
\hline $\begin{array}{l}\text { 19-oji tarptautinè konferencija „Matematinis } \\
\text { modeliavimas ir analizé“ }\end{array}$ & Gegužès 26-29 d. & 82 & 51 & 82 & 51 \\
\hline $\begin{array}{l}\text { Tarptautinė konferencija „Akustinės pastatų ir jų } \\
\text { aplinkos savybės“ }\end{array}$ & Rugsèjo $23 \mathrm{~d}$. & 38 & 13 & 13 & 8 \\
\hline $\begin{array}{l}\text { 11-asis tarptautinis seminaras „Aeronautikos } \\
\text { tyrimai ir studijos“ }\end{array}$ & Spalio $15-17 \mathrm{~d}$ & 50 & 30 & 48 & 30 \\
\hline $\begin{array}{l}\text { 3-ioji tarptautinè konferencija „Šiuolaikinės } \\
\text { verslo, vadybos ir studijų problemos'2014“ }\end{array}$ & Lapkričio 13-14 d. & 195 & 122 & 72 & 34 \\
\hline $\begin{array}{l}\text { Tarptautinè konferencija „Specialybės kalbos } \\
\text { studijos bendroje Europos aukštojo mokslo } \\
\text { erdvėje: teorija ir praktika“ }\end{array}$ & Lapkričio 22-23 d. & 62 & 6 & 30 & 5 \\
\hline & Iš viso & 939 & 502 & 554 & 294 \\
\hline
\end{tabular}

4.7 lentelè. Respublikinès konferencijos $2014 \mathrm{~m}$.

\begin{tabular}{l|c|c|c|c|c}
\hline \multicolumn{1}{c|}{ Renginys } & \multirow{2}{*}{ Data } & \multicolumn{2}{c}{ Dalyvių skaičius } & \multicolumn{2}{c}{ Pranešimų skaičius } \\
\cline { 3 - 6 } & & bendras & iš kitų institucijų & bendras & iš kitų institucijų \\
\hline $\begin{array}{l}\text { Respublikinis XXII Lietuvos skaičiuojamo- } \\
\text { sios mechanikos seminaras }\end{array}$ & Balandžio 25 d. & 23 & & 10 \\
\hline Respublikinè konferencija „eStream“ & Gegužès 5 d. & 27 & 5 & 13 & 2 \\
\hline & Iš viso & 50 & 5 & 23 & 2 \\
\hline
\end{tabular}

4.8 lentelè. Jaunujų mokslininkų konferencija „Mokslas - Lietuvos ateitis“ 2014 m.

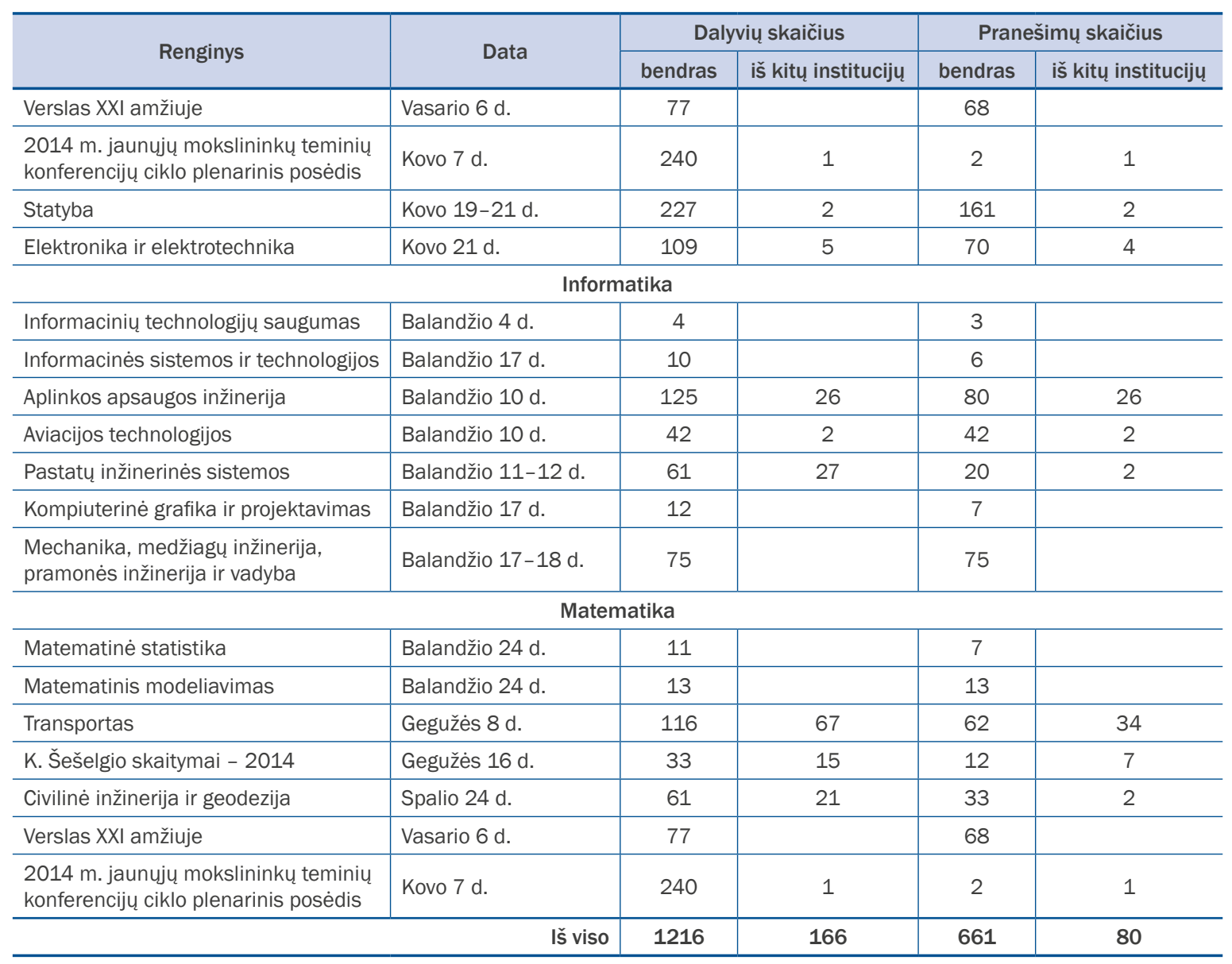




\section{Išradybinè veikla}

Išradybinę veiklą universitete geriausiai apibūdina 4.9 lentelėje pateikti pastarujų metų išradybinès veiklos rodikliai.

Lentelès duomenys liudija ne tik šios veiklos stabilumą, bet ir nusako kokybinius pokyčius. Iš esmès naujas tarptautinis išradybinès veiklos etapas pradėtas 2008 m., padavus pirmają Vilniaus Gedimino technikos universiteto patentinę paraišką Europos patentų tarnybai. Šiuo metu Europos patentų tarnyboje nagrinèjamos septynios VGTU patentinės paraiškos. 2014 m. VGTU pirmą kartą paduotos patentinės paraiškos Japonijos ir Korejjos patentu tarnyboms (V. Bučinsko, V. Augustaičio ir E. Šutinio išradimui „Plieninio lyno kokybejs diagnostikos būdas ir įranga“, kurio patentavimo procedūra buvo pradèta per WIPO).

Išradybinè veikla labai suaktyvèjo prie VGTU prisijungus Termoizoliacijos mokslo institutui. Šio instituto mokslininku atliekami darbai yra labai patentabilūs, atspindi statybų sektoriaus poreikius ir darnios aplinkos kūrimo strategiją. Tu darbų rezultatas - net 12 patentų iš 38 VGTU gautuju 2011-2014 m. ir viena patentine paraiška Europos patentui gauti, paduota $2012 \mathrm{~m}$.

4.9 lentelè. VGTU išradybinès veiklos rodikliai

\begin{tabular}{|c|c|c|c|c|c|}
\hline & 2010 & 2011 & 2012 & 2013 & 2014 \\
\hline $\begin{array}{l}\text { Paduota tarptautinių paraišku } \\
\text { Pasaulinei intelektinès nuosavybès } \\
\text { organizacijai (WIPO) }\end{array}$ & & & 1 & & \\
\hline $\begin{array}{l}\text { Paduota paraiškų kitų šalių patentų } \\
\text { tarnyboms }\end{array}$ & & & & & 2 \\
\hline Gauta Lietuvos patentų & 5 & 7 & 11 & 12 & 8 \\
\hline $\begin{array}{l}\text { Galiojančių patentų skaičius } \\
\text { gruodžio } 31 \mathrm{~d} \text {. }\end{array}$ & 15 & 20 & 26 & 34 & 38 \\
\hline
\end{tabular}

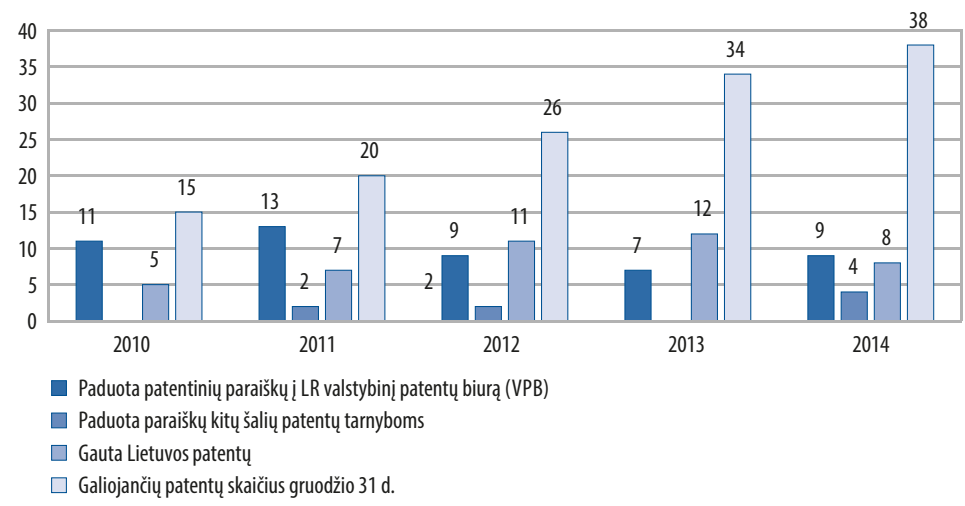

4.14 pav. Patentavimo dinamika

2014 m. parengta ir pateikta trylika patentinių paraiškų, net septynios iš jų - iš statybinių medžiagų srities. 2014 m. pabaigoje VGTU turejo 38 galiojančius patentus.

Valstybè ir toliau vykdo 2008 m. pradètą patentavimo rèmimo procesą. l ji aktyviai įsitraukè ir mūsų universitetas. Per visą laikotarpi nuo 2009 m. iš viso universitetas patentavimui jau gavo per 152 tūkst. litų paramą. 2014 m. gauta 15,32 tūkst. Lt parama išradimo „Daugialygis daugiakanalis cilindrinis ciklonas-filtras“ Europos patentavimo procedūros išlaidoms dengti.

Beveik visi išradimai atitinka prioritetines aplinkos ir energijos technologiju, darniosios statybos, mechatronikos mokslo kryptis. Juose sprendžiami konkretūs jivairių pramonės šakų ir mokslo techniniai uždaviniai ir problemos.

Nepaisant siūlomų sprendimų aktualumo ir inovatyvumo, išradimų komercinimas vis dèlto tebelieka probleminiu klausimu. Neatsirandant realių komercinimo galimybių, kasmet nutraukiamas kelių patentų galiojimo palaikymas. Universitetas turi teisę parduoti (licencijuoti) savo turimus patentus kaip intelektinès veiklos rezultatą ir užsidirbti papildomų lèšu iš savo mokslininkų techninès kūrybinès veiklos. Išradimų ir patentu pasiūla yra, 
bet nèra jų paklausos. Verslui vis dar trūksta pozityvaus požiūrio į mokslo rezultatų naudojimą kaip i vieną iš sèkmingo verslo vystymo priemonių. Čia ypatingos svarbos klausimu tampa mokslo ir verslo, mokslo ir pramonės ryšių stiprinimas. Siekiant sustiprinti ši segmentą, universitete įsteigtas Žinių ir technologijų perdavimo centras, kurio pagrindiniai uždaviniai - skatinti mokslo ir verslo partnerystę, siekti efektyvaus universiteto mokslininku ir studentų MTEP rezultatų naudojimo ir komercinimo, organizuoti universiteto MTEP veiklos ir paslaugų pardavimą ir rinkodarą.

\subsection{Doktorantūra ir tyrèjų ugdymas}

2014 m. VGTU igijo teisę vykdyti aplinkos inžinerijos mokslo krypties trečiosios pakopos studijas, papildydamas jau turimų mokslo krypčių sąrašą iki dešimties:

- menotyros - 03H (kartu su Klaipėdos universitetu);

- vadybos - 03S;

- ekonomikos - 04S (kartu su Lietuvos socialinių tyrimų centru ir Lietuvos agrarinès ekonomikos institutu);

- elektros ir elektronikos inžinerijos - 01T (kartu su Valstybiniu mokslinių tyrimų institutu Fizinių ir technologijos mokslų centru);

- statybos inžinerijos - 02T;

- transporto inžinerijos - 03T (kartu su Aleksandro Stulginskio universitetu ir Klaipėdos universitetu);

- aplinkos inžinerijos - 04T;

- informatikos inžinerijos - 07T (kartu su Kauno technologijos universitetu);

- medžiagu inžinerijos - 08T;

- mechanikos inžinerijos - 09T.

Iki 2015 m. gruodžio 31 d. mūsų universitetas gali organizuoti doktorantūros studijas ir teikti dar penkių mokslo krypčių (šakų), kurių doktorantai priimti iki 2011 m. liepos 31 d., mokslo daktaro laipsnius:

- matematikos - 01P;

- fizikos - 02P (kondensuotos medžiagos P260);

- chemijos inžinerijos - 05T (biotechnologija T490);

- energetikos ir termoinžinerijos - 06T;

- matavimų inžinerijos - 10T.

Lietuvos mokslo Taryba 2014 m., ivertinusi VGTU vykdomą menotyros, informatikos inžinerijos ir medžiagu inžinerijos mokslo krypčių mokslo doktorantūrą, savo išvadose patvirtino, kad šių krypčių doktorantūros procesas vykdomas kokybiškai ir veiksmingai.

2014 m. i doktorantūrą priimti 44 doktorantai, iš jų 42 - i nuolatines studijas ir 2 - i ištęstines (4.15 pav.). Valstybès finansuojamose vietose studijas pradejo 27 doktorantai: 26 - nuolatinès studiju formos ir 1 ištęstinès. 2014 m. ypač padaugèjo nuolatinès studijų formos doktorantų, kurių studijos finansuojamos Europos Sajungos struktūrinių fondų lèšomis. Priimta net 16 tokių doktorantų (4.16 pav.). Vienas ištęstinės studiju formos doktorantas studijas finansuoja savo lèšomis.

Nuolatinès studijų formos doktorantams skiriama doktoranto stipendija. Pirmaisiais studijų metais jie gauna 1079 Lt dydžio stipendiją, nuo antruju - 1248 Lt. VGTU doktorantu studijas papildomai rèmè ir Lietuvos mokslo Taryba - 41 doktorantui buvo skirta stipendija už akademinius pasiekimus.

2014 m. pabaigoje VGTU doktorantūroje studijavo 189 doktorantai (4.17 pav.): 160 nuolatinèje doktorantūroje ir 29 - ištęstinèje.

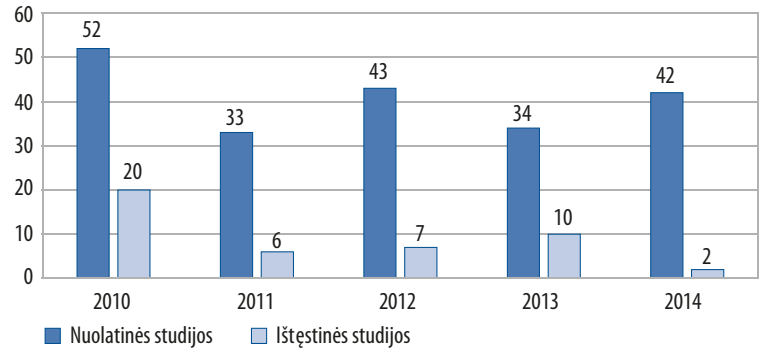

4.15 pav. 2014 m. priimtų studijuoti doktorantų skaičius

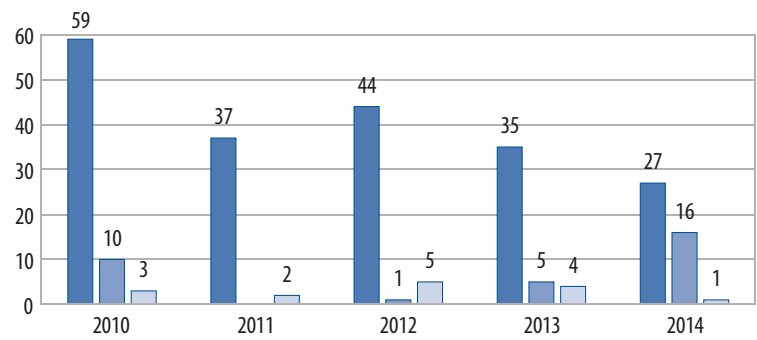

$\square$ Valstybès biudžeto lěšomis $\square$ ES struktūriniụ fondụ lèšomis $\square$ Studijuojantys savo lè̌̌omis

4.16 pav. 2014 m. priimtų studijuoti doktorantų pasiskirstymas pagal studijų finansavimo šaltini 
Daugiausia doktorantu - 142, t. y. net $75 \%$ visu doktorantu, studijavo technologijos mokslus: 127 nuolatinès studijų formos, 15 - ištęstinès. Socialinius mokslus studijavo 25 nuolatinès ir devyni ištęstinès studijų formos doktorantai, fizinius mokslus - du nuolatinès studiju formos doktorantai, humanitarinius mokslus - šeši nuolatinès ir penki ištęstinès studijų formos doktorantai (4.18 pav.).

Pagal mokslo kryptis doktorantai pasiskirstę netolygiai. Daugiausia yra šių mokslo krypčiu doktorantų: statybos inžinerijos - 46, transporto inžinerijos - 23. Kitų mokslo krypčių doktorantu yra šiek tiek mažiau. Mažiausiai studijuoja matavimų inžinerijos mokslo krypties doktorantų - du, o fizikos, matematikos ir aplinkos inžinerijos mokslo krypčiu - tik po vieną. Disertacijas jau apgynè paskutiniai energetikos ir termoinžinerijos mokslo krypties doktorantai, tad šios mokslo krypties doktorantų nebeliko.

Fakultetuose doktorantai irgi pasiskirstę nevienodai. Daugiausia doktorantu studijuoja Statybos fakultete - 44. Kituose fakultetuose doktorantu skaičius pasiskirsto taip: Verslo vadybos - 29, Fundamentinių mokslų - 23, Aplinkos inžinerijos ir Elektronikos fakultetuose - po 19, Transporto inžinerijos - 16, Mechanikos - 16, Architektūros - 11, Termoizoliacijos mokslo institute - 7, Antano Gustaičio aviacijos institute - 5 doktorantai (4.19 pav.).

VGTU doktorantams vadovauja 99 universiteto mokslininkai: 65, einantys profesoriaus pareigas, ir 34 docento pareigas.

Kiekvienų mokslo metų pabaigoje doktorantai atestuojami. Atestuojant doktorantus už 2013-2014 m. m. paaiškèjo, kad iš 212 doktorantu 190 sẻkmingai vykdè studiju ir mokslinių tyrimu planą, o neatestuoti tik keturi doktorantai. Mokslo metų pabaigoje, kai vyko metinė atestacija, 15 doktorantų buvo išèję akademinių atostogu, o trys doktorantai dèl ịvairių priežasčių buvo atleisti iš doktorantūros iki atestacijos. 2014 m. VGTU doktorantai buvo išvykę i dvidešimt aštuonias vieno mėnesio ar ilgesnès trukmės stažuotes užsienio universitetuose ir mokslinių tyrimų institutuose.

2014 m. VGTU apgintos 52 mokslo daktaro disertacijos, kurios pagal mokslo kryptis pasiskirsto taip:

- statybos inžinerija -15;

- ekonomika - 6;

- mechanikos inžinerija - 6;

- elektros ir elektronikos inžinerija - 5;

- transporto inžinerija - 4;

- aplinkos inžinerija - 3;

- informatikos inžinerija - 3;

- matavimų inžinerija - 3;

- energetika ir termoinžinerija - 2;

- matematika - 2;

- medžiagų inžinerija - 1;

- menotyra - 1;

- vadyba - 1.

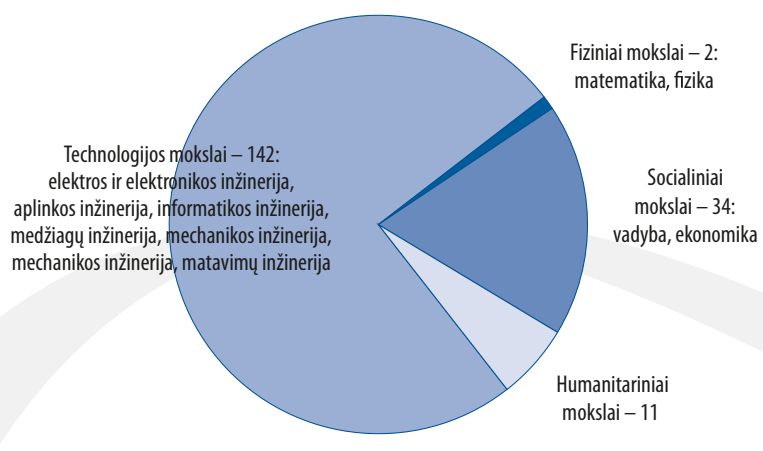

4.18 pav. Doktorantų skaičius pagal mokslų sritis

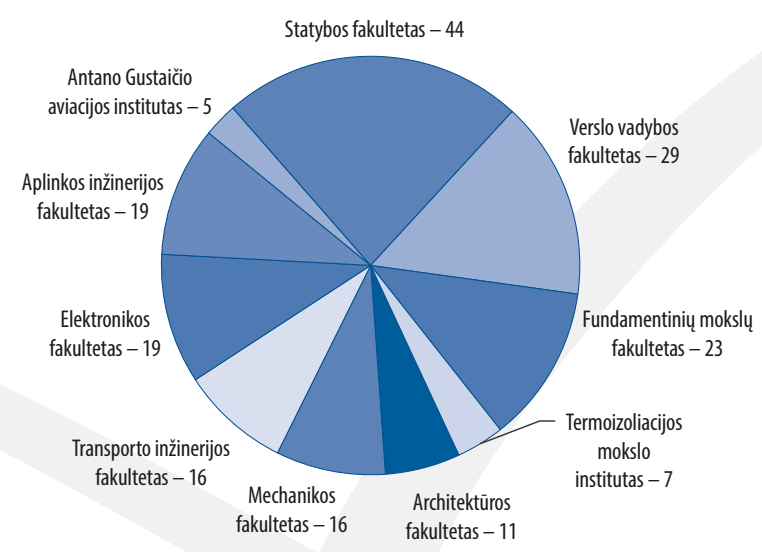

4.19 pav. Doktorantų skaičius pagal fakultetus 
Pagal disertacijų rengimo trukmę $2014 \mathrm{~m}$. apgintos disertacijos pasiskirsto taip (4.20 pav.):

- 9 disertacijos apgintos iki doktorantūros studiju pabaigos;

- 38 disertacijos apgintos iki ginti skirto termino pabaigos;

- 5 disertacijas apgynè eksternai, anksčiau studijavę VGTU doktorantūroje.

Doktorantūros studijas jau baigè pirmoji doktorantų, kurie gina disertacijas pagal 2010 m. patvirtintus Mokslo doktorantūros nuostatų reikalavimus, laida, todèl labai padaugejjo mokslininkų iš užsienio mokslo ir studijų institucijų, atvykstančių dalyvauti disertacijų gynimo tarybose. 2014 m. buvo suformuotos net 27 disertaciju gynimo tarybos, kuriose dalyvavo profesoriai iš užsienio universitetu, t. y. net tris kartus daugiau nei ankstesniais metais.

Nemaža dalis sėkmingai disertacijas apgynusių mokslo daktarų ir toliau tęsia savo mokslinę bei pedagoginę veiklą VGTU - iš 52 mokslo daktarų, disertacijas apgynusių 2014 m., 32, t. y. 62 \%, liko dirbti mūsų universitete (4.21 pav.).

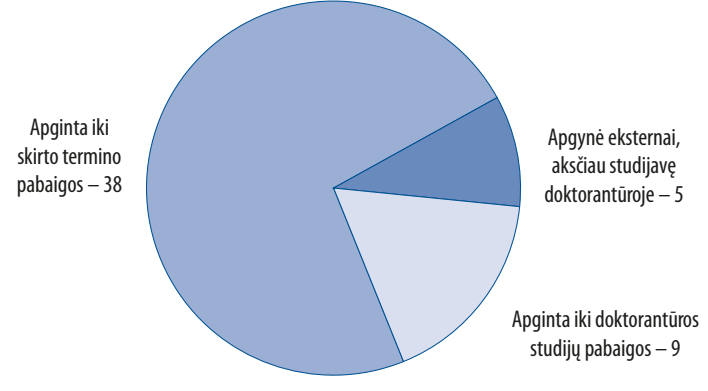

4.20 pav. VGTU $2014 \mathrm{~m}$. apgintu mokslo daktaro disertacijų rengimo trukmè

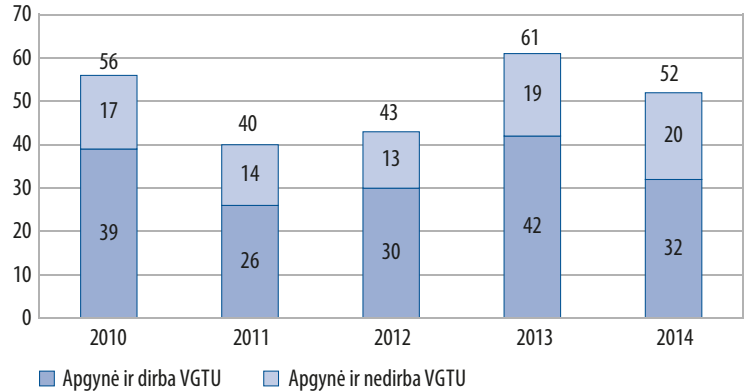

4.21 pav. VGTU parengtų mokslo daktaru tolesnè karjera

Moksliniai VGTU doktorantu tyrimai ir apgintos disertacijos $2014 \mathrm{~m}$. buvo ivvertinti ir už universiteto ribų. Prezidentūroje šalies Prezidentė Dalia Grybauskaitè už vieną geriausių daktaro disertacijų humanitarinių ir socialinių mokslų srityse apdovanojo VGTU eksternu daktaro disertaciją apgynusi Justiną Buči, o nominacija už geriausią disertaciją aplinkosaugos tema skirta Ingai Jakštonienei. Susisiekimo ministerijos organizuotame konkurse geriausia disertacija transporto tema pripažinta VGTU apginta Aurimo Vilkelio daktaro disertacija. Lietuvos mokslų akademijos jaunujų mokslininkų mokslinių darbų konkurse premijomis ir pagyrimo raštais apdovanotos VGTU jaunujų mokslininkų Raimondo Buckaus parengta aplinkos inžinerijos mokslo krypties daktaro disertacija ir Algimanto Mačiulio parengta menotyros mokslo krypties daktaro disertacija. 


\section{Poveikis regionui ir šalies raidai}
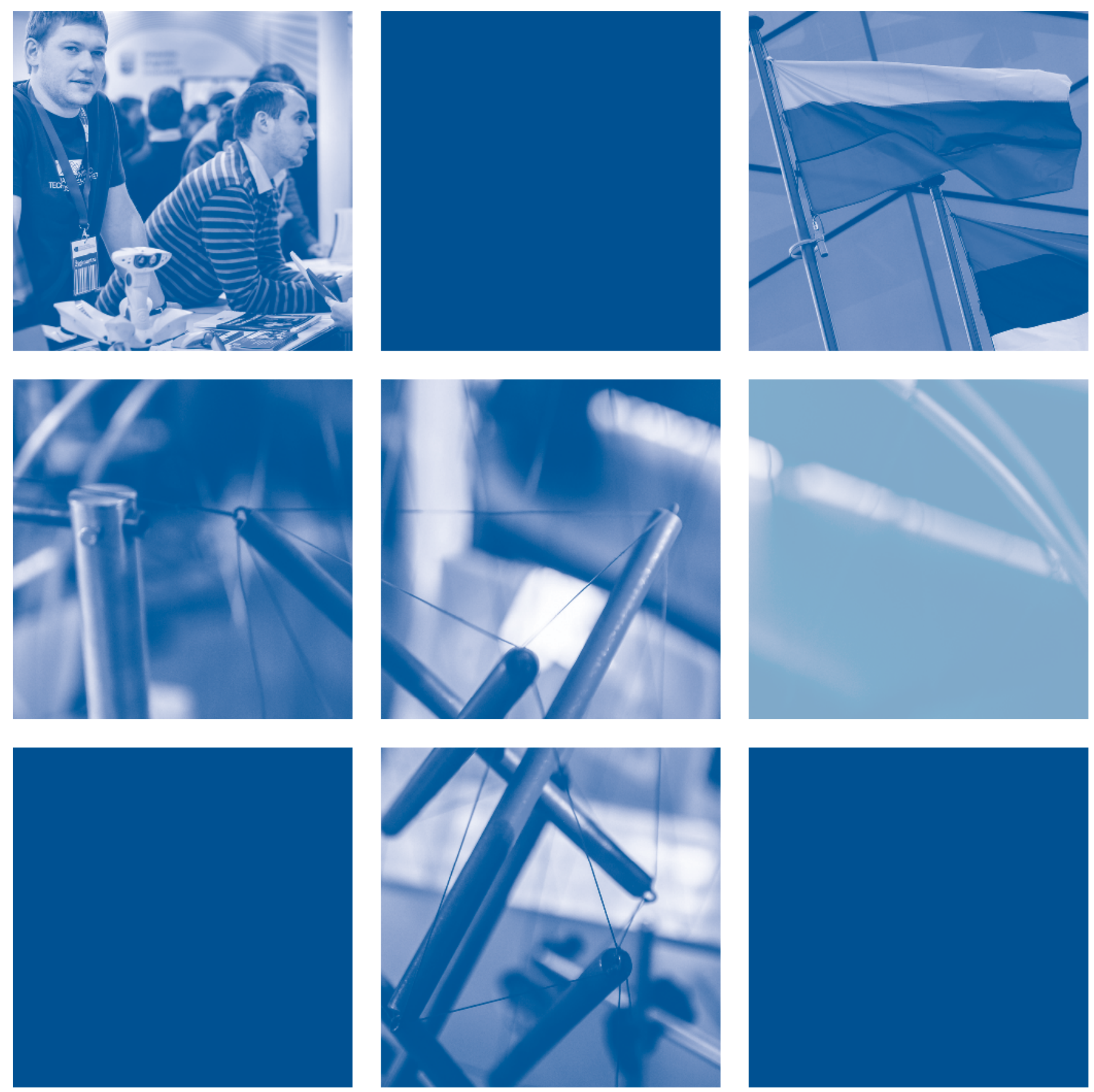



\section{Poveikis regionui ir šalies raidai}

\subsection{Universitetas regionui, valstybei ir miestui}

VGTU savo poveiki regiono ir valstybès raidai (universiteto „trečiają misiją“) nuosekliai sieja su studijomis ir mokslo (meno) veikla: rengia aukščiausios kvalifikacijos specialistus ir vykdo taikomuosius tyrimus, atsižvelgdamas i valstybės darnaus vystymosi poreikius. Igyvendinant universiteto misiją pabrěžiama priedermè skleisti mokslo žinias, ugdyti visuomenès, kuri suponuoja poreiki plètoti mokslo, studijų ir praktikos sąveiką (Plètros plano 3 strateginis tikslas), narius pabrėžiant mokslo tiriamujų darbų rezultatų diegimą i gamybą ir tęstinių studijų pasiūlos didinimą.

Sutelkiant žmogiškuosius, finansinius ir administracinius išteklius, siekiama geriau parengti jaunuosius tyrèjus, tobulinti MTEP žmogiškuosius išteklius ir efektyviau naudoti jau sukurtą MTEP infrastruktūrą, o siekiant užtikrinti vykdomų MTEP darbų kokybę ir aktualumą bus aktyviau įsitraukiama i tarptautinius MTEP institucijų ir tyrejjų tinklus. Siekiant universiteto MTEP veiklos tarptautinio pripažinimo skatinamas MTEP darbu rezultatų publikavimas pripažintuose tarptautiniuose mokslo žurnaluose, MTEP rezultatų komercinimas, žinių ir technologiju perdavimas ir dalyvavimas prestižinėse savo srities mokslinėse konferencijose.

Plètodamas tarptautinį bendradarbiavimą, universitetas palaiko dalykinius ryšius ne tik su verslo įmonėmis, Lietuvos ir užsienio mokslo bei technologiju centrais, technologiniais parkais ir integruotais mokslo ir studiju slèniais, bet ir skatina MTEP centrų kūrimą VGTU ir jų integravimą i pasaulinès vertès kūrimo grandines, suteikiančias prieigą prie pasaulinių žinių ir idejjų išteklių, naujų iššūkių ir modernių technologijų, siekiant sukurti dvikryptę geriausių inovatyviu praktikų tarp universiteto ir partnerių perdavimo sistemą.

Šiuo metu statybos pramonè yra įžengusi i beprecedenti inovacijų ir drąsių eksperimentų laikotarpi, kuri daugiausia lemia technologijos. Sparčiai besivystant informacinėms technologijoms statybos industrijos srityje, kompiuterinio projektavimo, kompiuterizuoto statybos proceso organizavimo ir objekto valdymo koncepcija nuolat plečiasi ir igyja naują prasmę. Statinio (pastato) informacinio modeliavimo (SIM, angl. BIM) sistemu plètra ir intensyvus vystymas ir yra šiuolaikinių skaitinių bei informacinių technologijų statybos inžinerijos bei architektūros ir daugiausia aplinkos, transporto, infrastruktūros inžinerijos srityse pagrindinè varomoji jẻga, esmè ir turinys. 2014 m. universitete buvo įkurtas Statinių skaitmeninio ir informacinio modeliavimo technologiju centras.

Siekiant, kad universiteto teikiamos paslaugos atitiktų verslo poreikius, skatinamas glaudesnis mokslo ir verslo bendradarbiavimas, veiksmingesnis turimų išteklių naudojimas ir jų i̊sitraukimas i vertès kūrimo procesus. VGTU mokslo padaliniai organizuoja seminarus su Lietuvos verslo įmonèmis, kurių tikslas - supažindinti imoniu specialistus su VGTU vykdomais darbais ir teikiamomis paslaugomis bei bendradarbiavimo galimybėmis. Pvz., Termoizoliacijos mokslo instituto organizuotas susitikimas sunkiomis ugniai atsparių medžiagu eksploatacijos sąlygomis ypatumams aptarti su UAB „Kaefer-Lietuva“, UAB „Izola“, AB „Vilniaus energija“, UAB „Axis Technologies“, UAB „Biokaitra“, UAB „Fortum“.

Skatinant žinių, technologiju perdavimo, MTEP rezultatų komercinimo, verslumo, inovaciju kultūros ugdymo veiklas, 2014 m. buvo įkurtas Žinių ir technologijų perdavimo centras. Jo pagrindiniai uždaviniai - skatinti VGTU vykdomų mokslo tyrimų, eksperimentinès plètros rezultatų komercinimą, žinių ir technologijų perdavimą, mokslo ir verslo partnerystę, tarptautinį bendradarbiavimą MTEP ir inovacijų srityje, verslumo kultūros ugdymą ir naujo inovatyvaus verslo (verslą pradedančių i̇monių, pumpurinių i̇monių) kūrimąsi, kūrybingos, inovatyvios visuomenès kūrimą.

Apibūdinant universiteto regioninio poveikio mastą, analizuojamas VGTU indèlis sprendžiant Baltijos jūros regiono problemas. Šioje veikoje didelę patirtị turi Transporto inžinerijos, Aplinkos inžinerijos, Statybos inžinerijos, Fundamentinių mokslų fakulteto mokslininkai: vykdomi keturi Baltijos jūros regiono tarpvalstybinio bendradarbiavimo (BSR) programos projektai.

Lietuvoje ir kitose regiono šalyse universiteto tyrèjų grupės vykdè mokymus jauniesiems mokslininkams, doktorantams, tyrejjams, profesionalams ir politikams, dirbantiems regionų politikos igyvendinimo ir teritoriju planavimo srityse (EnECon projektas). 2014 m. universiteto mokslininkai aktyviai vykdè projektus pagal Lietuvos ir Baltarusijos dvišalio bendradarbiavimo programą. 
Aktyviai universiteto vardą garsino meno kolektyvai. Jie 2014 m. padèjo rengti ir koncertavo ivvairiuose universiteto renginiuose bei šventèse. Veiklos rodikliai pateikti 5.1 lentelèje.

Aktyviai švietejišką veiklą plètojo ir VGTU biblioteka. 2014 m. bibliotekos meno Galerijoje A parengta 11 parodų. Svarbiausios iš jų: VI Klaipėdos valstybinio jūrų uosto direkcijos paroda "Lietuvos transporto širdies - Klaipėdos uosto raida“, Švedijos ambasados surengta paroda „Akistata su klimatu“, Henriko Ratkevičiaus paroda „Exlibris'ai“, Jūratė Buožienè tekstilès darbu paroda „Donelaitis drobẻje“, lietuvių išeivio fotografo Algimanto Kezio fotografijų paroda „LITHUANIA“, fotografo, alpinisto Romualdo Augūno fotografijų paroda „Sapnuoju Lietuvą“.

Bibliotekoje buvo parengtos septynios teminès parodos. Didžiausio susidomèjimo ir pasisekimo sulaukè doc. Kęstučio Skerio kolekcinè pieštukų paroda, apie kurią buvo parengtas reportažas per Lietuvos televiziją.

Visada džiugina bendradarbiavimas su kitais universiteto padaliniais, kurie rūpinasi dvasine universiteto bendruomenès kultūra. Tarpininkaujant Darbo ir gaisrinès saugos katedrai vyko Valstybinès darbo inspekcijos ir Vilniaus dailès akademijos bendro projekto „I darbą - kaip i karą?“ baigiamasis renginys. Vilniaus dailès akademijos Grafinio dizaino katedros studentai kūrè logotipą, skatinantị saugoti savo ir kitų sveikatą ir gyvybę darbe.

5.1 lentelè. Meno kolektyvų veikla

\begin{tabular}{|c|c|c|}
\hline Meno kolektyvas & $2014 \mathrm{~m}$. & Apdovanojimų skaičius \\
\hline VGTU teatro studijos „Palėpé“ & 78 & 8 \\
\hline VGTU tautinių šokių ansamblis „Vingis“ & 43 & 36 \\
\hline VGTU orkestras & 22 & 10 \\
\hline VGTU choras „Gabija“ & 33 & 31 \\
\hline Iš viso & 176 & 85 \\
\hline
\end{tabular}

Stojančiujų priėmimo ir informavimo centro ir kitų universiteto padalinių darbuotojai aktyviai dalyvauja tarptautinėse parodose ir šalyje vykdomuose projektuose, pavyzdžiui, „Resta“, „Infobalt“, „Balttechnika“, Vilniaus knygų mugè, „Tyrèjų naktys“, „Erdvèlaivis Žemè“. Jie populiarina universiteto studijas, skatina visuomenę domètis mokslo perspektyvomis, siekti žinių.

Tampa gera tradicija organizuoti universitete Vilniaus savivaldybės bendrojo ugdymo istaigu vadovu pasitarimą, kurio metu dalyviai susipažindinami su prièmimo i studijas aktualijomis, studiju programu ịvairove, mokyklų bendradarbiavimo su universitetu galimybėmis.

2014 m. Vilniaus Gedimino technikos universiteto padaliniuose buvo organizuojami kvalifikacijos tobulinimo kursai (toliau - KTK), kurie yra viena iš Mokymosi visą gyvenimą (MVG) sudedamujų dalių. 2014 m. už KTK organizavimą gauta 400 tūkst. Lt pajamų. KTK organizavo penki fakultetai: Aplinkos inžinerijos, Mechanikos, Statybos, Transporto inžinerijos, Architektūros, ir Antano Gustaičio aviacijos institutas. Kitų fakultetų indèlis - nulinis.

Daugiausia lèšų iš KTK organizavimo gavo Aplinkos inžinerijos fakultetas - beveik 200 tūkst. litų. Kitų fakultetų indèlis - kuklesnis, nesiekia 100 tūkst. litų.

Reikètų paminèti darbuotojus, kurie KTK organizavimo naudą suprato ir kasmet šią veiklą vis plečia. Tai Aplinkos apsaugos katedros prof. P. Baltrènas, AGAI Aviacijos specialistų kvalifikacijos tobulinimo centro direktorius J. V. Jusionis, Jaunujų architektų ir dizainerių mokyklos direktorius G. Navickas, Medžiagotyros ir suvirinimo katedros doc. N. Višniakov, Mechanikos inžinerijos katedros doc. V. Mokšin, Darbo ir gaisrinès saugos katedros vedejjas prof. R. Šukys.

Prof. P. Baltrènas pradejjo organizuoti kursus net Rusijos piliečiams, dirbantiems aplinkosaugos srityje. Šių kursų klausytojai yra iš įvairių Rusijos miestų.

Gaila, kad kol kas universiteto padaliniai nepasinaudojo VGTU suteikta galimybe KTK rengti valstybės tarnautojams. Anksčiau KTK valstybės tarnautojų mokymus yra rengęs Aplinkos inžinerijos fakultetas. Gali atsitikti taip, kad iš VGTU bus atimta teisè tai daryti, jei artimiausiu metu ši veikla nebus vykdoma. Dèl valstybès tarnautojų mokymo turètų daugiau pasistengti Verslo vadybos fakulteto administracija ir dèstytojai.

Universiteto padalinių vadovai turètų rimtai pagalvoti, kaip suaktyvinti KTK organizavimą, nes studentų skaičiaus mažejjimas verčia ieškoti kitų veiklos sričių. KTK organizavimas - viena iš studijų proceso alternatyvų.

Nors mokymosi visą gyvenimą formų ivairovè plečiasi, tačiau apimtis nesikeičia mokymų ir jų formų ivairove. Registruojamu programu skaičius proporcingai nedidina MVG igyvendinimo rodiklių - klausytojų augimo, ekspertiškumo didinimo, finansinio našumo, kuris sudaro 0,6 \% viso VGTU metinio biudžeto.

VGTU nutarta vystyti šias MVG formas:

- kvalifikacijos tobulinimo kursai;

- mokymai valstybės tarnautojams; 
- užsienio kalbų kursai;

- mokymai moksleiviams;

- mokymai VGTU darbuotojams;

- mokymai užsieniečiams;

- dalinès studijos;

- LR ministeriju sertifikuoti mokymai;

- neformaliuoju būdu igytu kompetenciju pripažinimas;

- specialistų konsultacijos įmonėms ir fiziniams asmenims;

- mokymai pagal individualu planą nutraukusiems studijas;

- profesinio mokymo laipsnio nesuteikiančios programos;

- išvažiojamieji mokymai organizacijose.

\subsection{Bendradarbiavimas su mokslo ir kitais socialiniais partneriais}

Vienas prioritetinių Integracijos ir karjeros direkcijos uždavinių - stiprinti partnerystę su Lietuvos strateginėmis, sektorinėmis ir tarptautinėmis organizacijomis, konfederacijomis, imonėmis, siekiant sudaryti palankiausias sąlygas universiteto studentams pažinti rinką, ugdyti gebėjimus, sėkmingai joje veikti. Realizuojant ši uždavini 2014 m. pasirašyta 40 bendradarbiavimo sutarčių. Iš ju strateginė bendradarbiavimo sutartis pasirašyta su savivaldybės imone Šiaulių oro uostu. Stiprinta partnerystė su šiomis asociacijomis: Nacionaline pasyvaus namo asociacija, Lietuvos leidèju asociacija, Lietuvos ergonomikos asociacija, taip pat su privataus kapitalo organizacijomis (5.1 pav.). Sudarant bendradarbiavimo sutartis, sutariama dèl bendradarbiavimo pobūdžio trijose esminèse srityse: studentų praktikų organizavimo, studentų karjeros ugdymo, bendrų iniciatyvų skatinimo ir vykdymo.

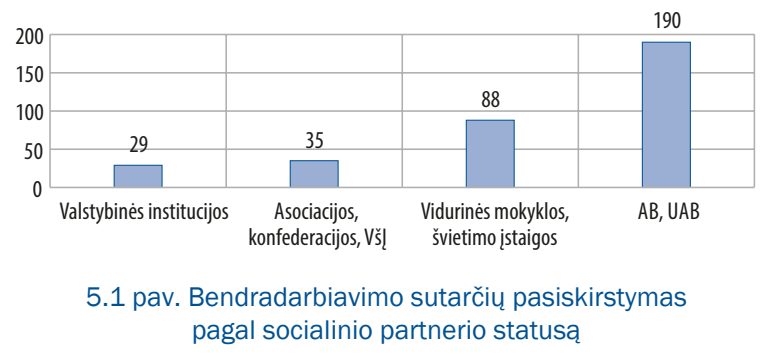

Atsižvelgiant i bendradarbiavimo sutarčių pasiskirstymą pagal socialinio partnerio statusą, VGTU daugiausia yra sudaręs sutarčių su akcinėmis ir uždarosiomis akcinėmis bendrovėmis. Skiriamas dèmesys partnerystei su vidurinėmis mokyklomis, gimnazijomis ir kitomis švietimo istaigomis. Integracijos ir karjeros direkcija, glaudžiai bendradarbiaudama su universiteto fakultetais, skatino pasirašytų bendradarbiavimo sutarčiu numatytu veiklų igyvendinimą.

Siekiant palaikyti glaudų ryši su bendrojo lavinimo mokyklų ir gimnazijų mokiniais bei mokytojais, sudaromos bendradarbiavimo su universitetu sutartys. 2014 m. pasirašytos devynios naujos sutartys, iš jų dvi - dèl VGTU klasių steigimo. Tai skatina mokyklose daugiau dėmesio skirti mokiniu profesiniam informavimui, populiarinti technologijos mokslus, VGTU studiju programas, o universiteto darbuotojus ipareigoja organizuoti moksleiviams užsièmimus, paskaitas, dalyvauti ịvairiuose moksleivių projektuose, konkursuose.

Stojančiujų prièmimo ir informavimo centro (SPIC) iniciatyva universitete mokslo metų pradžioje vyko seminaras mokyklų karjeros ugdymo specialistams „Moksleivis - profesinis informavimas - studentas“. ! rengini pakviesti mokytojai iš visos Lietuvos. Seminaru dalyviams buvo padalyta informacinè reklaminè medžiaga, kuri pasiekė mokinius, t. y. atsirado mokyklų skelbimų lentose, bibliotekose, profesinio informavimo kabinetuose, mokyklu tinklalapiuose. 0 ir patys mokytojai galejjo suteikti daugiau informacijos mokiniams apie studiju galimybes VGTU ir pačias studijas, nes išklausė paskaitų, aplankè laboratorijas, bendravo su dèstytojais ir studentais.

Atsiliepus i komunikacijos agentūros Bosanova pasiūlymą dalyvauti projekte „Renkuosi tiksliuosius“, universitete buvo organizuotas renginys tuo pačiu pavadinimu, kuriame dalyvavo šalies mokyklu delegacijos. Tą dieną mokiniai galèjo pasijausti studentais, išklausyti rimtų paskaitų apie ateities statybas, informacinių technologijų perspektyvas, apžiūrèti naujausias VGTU laboratorijas. Stojimo i studijas klausimais konsultavo SPIC darbuotojai. 


\subsection{Universitetas moksleiviams}

Stojančiujų prièmimo ir informavimo centro darbuotojai, pasitelkdami aktyvius universiteto fakultetų darbuotojus ir studentus, ištisus mokslo metus vykdo švietejjišką ir informacini darbą, kurio tikslas - vyresniujų klasių mokiniams padèti apsispręsti renkantis profesiją, jaunesnių klasių vaikus sudominti tiksliaisiais mokslais, skatinti pažinti mokslo ịvairovę. Kuo ankstesnèse klasėse moksleiviai sužino apie studijuojamus mokslus universitete, karjeros perspektyvas, priėmimo i studijas tvarką, tuo geriau gali ivertinti savo galimybes, iškelti aiškesnius tikslus renkantis studijas, tuo didesnè jų motyvacija studijuoti, siekti lyderio pozicijos (5.2 lentelè).

Informacinis darbas vykdomas pasitelkiant ivairias jo formas. Viena iš ju - Jaunojo inžinieriaus mokykla (JIM). JIM paskaitos, praktiniai užsiėmimai ir teminès ekskursijos vyresniujų klasių mokiniams organizuojamos jau penkti metai. JIM užsiėmimai padeda pažinti studijų programas, atskleisti jų idomiąsias puses, pritaikymo galimybes. Paskaitos filmuojamos ir dedamos i universiteto tinklalapi, kad informacija pasiektų kuo platesnę jaunimo auditoriją. Paskaitas skaito ịvairių fakultetų dėstytojai, mokslo ir tyrimų centrų darbuotojai. Šios paskaitos vyko ne tik universitete, bet ir kitose erdvėse, pvz., Eismo valdymo centre Vilniuje, Vilniaus regiono aplinkos apsaugos departamento Valstybinès analitinės kontrolès skyriuje, Klaipėdos, Birštono, Kretingos, Pasvalio, Kupiškio, Vilniaus ir kitų miestų gimnazijose ir vidurinėse mokyklose. 2014 m. vyko daugiau nei $30 \mathrm{JIM}$ paskaitų.

Nuolat vyksta susitikimai su Lietuvos mokyklų ir gimnazijų mokiniais, moksleivių tèvais mokyklose ir priimant juos universitete, dalyvaujant mokyklose rengiamose karjeros dienose, konferencijose, aukštujų mokyklų mugèse. Dalyvauta daugiau nei 100 tokių renginių. Universitete moksleivių delegacijos lankè laboratorijas, buvo supažindinamos su studijų procesu ir studentišku gyvenimu. Universitete vyko trys dideli renginiai, skirti besidomintiems studijomis VGTU: „Renkuosi studijas“, „Specialybės, keičiančios pasauli“ ir tradicinè Atviru durų diena.

Su mokiniais susitinkama ir vykdoma švietėjiška misija universitete vykstančiuose renginiuose - Makaronų tiltu statybos čempionate, renginyje „Krèslas - mano pirmoji statyba“ ir kt.

Sausio mėn. VGTU atstovai dalyvavo Kaune vykusioje Aukštujų mokyklų mugèje „Kur studijuoti?“, o vasario mèn. - tarptautinèje parodoje „Studijos 2014“ Lietuvos parodų centre „Litexpo“. Šios dvi parodos yra gausiai lankomos mokytojų, moksleivių, jų tèvų iš visos Lietuvos. Čia sulaukiame ypač didelio susidomèjimo bakalauro ir magistro studijomis, sulaukta klausimų apie doktorantūrą. Parodų konferencijų salèse buvo skaitomos paskaitos apie studijų ir studentiškos veiklos universitete galimybes, absolventu perspektyvas, vyko diskusijos su aktyviu ir smalsiu jaunimu, buvo demonstruojami mokslo ir technikos išradimai.

Savo veiklą tęse VGTU mobilioji aplinkos technologiju laboratorija, kuri keliauja po Lietuvos mokyklas ir skatina moksleivius domètis aplinkos tyrimais. Padedami Aplinkos apsaugos instituto darbuotojų, mokiniai išbando modernius prietaisus ir patys atlieka oro teršalų koncentraciju matavimus, triukšmo lygio ir mobiliuju telefonų elektromagnetinio lauko tyrimus. Praejjusiais metais užsièmimai jivyko šešiose mokyklose.

Plečiamas VGTU klasių tinklas - birželio mèn. buvo pasirašytos bendradarbiavimo dėl VGTU klasių steigimo sutartys su Vilniaus Vytauto Didžiojo ir Kèdainiu Šviesiaja gimnazijomis, kuriose 2014 m. vyko mokinių priėmimo konkursas i VGTU klases. Kartu su kitų aštuonių Lietuvos mokyklų VGTU klasių mokiniais jie universiteto chemijos, fizikos, bioinžinerijos laboratorijose atliko darbus, klausėsi matematikos, informacinių technologijų, ekonomikos paskaitų. Rezultatai, pateikti 5.3 lentelèje, iliustruoja šių klasių veiklą. Be šių VGTU klasių, universiteto užsièmimuose dalyvavo ir kitų Vilniaus mokyklų moksleiviai.

5.2 lentelè. 2014 m. jivykę užsièmimai universitete ir mokinių lankomumas

\begin{tabular}{l|c|c}
\hline \multicolumn{1}{c|}{ Katedra } & Iš viso užsièmimų katedroje & Mokiniai \\
\hline Fizikos katedra & 46 & 17 \\
\hline Telekomunikacijų inžinerijos katedra & 387 \\
\hline Chemijos ir bioinžinerijos katedra & 7 & 181 \\
\hline Matematinès statistikos katedra & 7 & 129 \\
\hline Informacinių sistemų katedra & 10 & 113 \\
\hline Inžinerinès grafikos katedra & 1 & 20 \\
\hline Poligrafinių mašinu katedra & 1 & 29 \\
\hline Miestu statybos katedra & 1 & 28 \\
\hline Architektūros inžinerijos katedra & 2 & 153 \\
\hline Socialinės ekonomikos ir vadybos katedra & 4 & 112 \\
\hline Imonių ekonomikos ir vadybos katedra & 1 & 17 \\
\hline Verslo technologijų katedra & 121 & 2005 \\
\hline
\end{tabular}


5.3 lentelè. Bendradarbiavimas su mokyklomis, kuriose yra VGTU klasės

\begin{tabular}{l|c|c|c}
\multicolumn{1}{c|}{ Mokykla } & Klasių skaičius & $\begin{array}{c}\text { Mokinių skaičius } \\
\text { VGTU klasėje }\end{array}$ & $\begin{array}{c}\text { Bendras istojusiujų i VGTU } \\
\text { skaičius mokykloje }\end{array}$ \\
\hline Vilniaus Mikalojaus Daukšos vidurinė mokykla & 7 & 146 & 32 \\
\hline Vilniaus Radvilų gimnazija & 4 & 106 & 22 \\
\hline Vilniaus Užupio gimnazija & 4 & 120 & 24 \\
\hline Vilniaus Vasilijaus Kačialovo gimnazija & 1 & 21 & 15 \\
\hline Vilniaus Žirmūnų gimnazija & 2 & 36 & 22 \\
\hline Vilniaus Juventos gimnazija & 2 & 52 & 9 \\
\hline Vilniaus Tuskulènų vidurinė mokykla & 4 & 95 & 25 \\
\hline Utenos Adolfo Šapokos gimnazija & 2 & 59 & 27 \\
\hline Vilniaus Vytauto Didžiojo gimnazija & 2 & 32 & 33 \\
\hline Kėdainių Šviesioji gimnazija & 1 & 17 & 224 \\
\hline
\end{tabular}

Universitetas padeda Vilniaus Mikalojaus Daukšos vidurinėje mokykloje užtikrinti inžinerinès krypties mokslų integravimą i bendrujų ugdymo programų turinį. Vyresnėse klasėse mokiniai mokosi pasirinktinai bent po vieną dalyką iš inžinerijos - bioinžinerijos, chemijos, dizaino ar civilinės - srities, atlieka profesinę inžinerinę praktiką. 2014 m. rudenį universitete buvo pravesti trys ịvadinių inžinerijos paskaitų ciklai sąlyginiais pavadinimais „Statyba“, „Dizainas“ ir „Mechanika“. Sėkmingai vyko paskaitos ir praktiniai užsièmimai - iš viso 87 akademinès valandos. 2015 m. vasario-gegužès mėn. vyks projektavimo pagrindų paskaitos ir pratybos, kuriuos parengè ir dèstys Inžinerinės grafikos katedros dėstytojai. VGTU pedagogu parengtos mechanikos inžinerijos ir dizaino bei civilinès inžinerijos dalykų programos, kurias numatoma dèstyti $2015 \mathrm{~m}$. rudenį. Iš mokytojų gauti mokinių atsiliepimai apie rudeni vykusias paskaitas yra išsamūs ir palankūs. Vyksta nuolatinis bendravimas su mokyklos atstovais, puikiai sutariant dèl mokymo eigos ir struktūros. 



\section{Administravimas ir ištekliai}
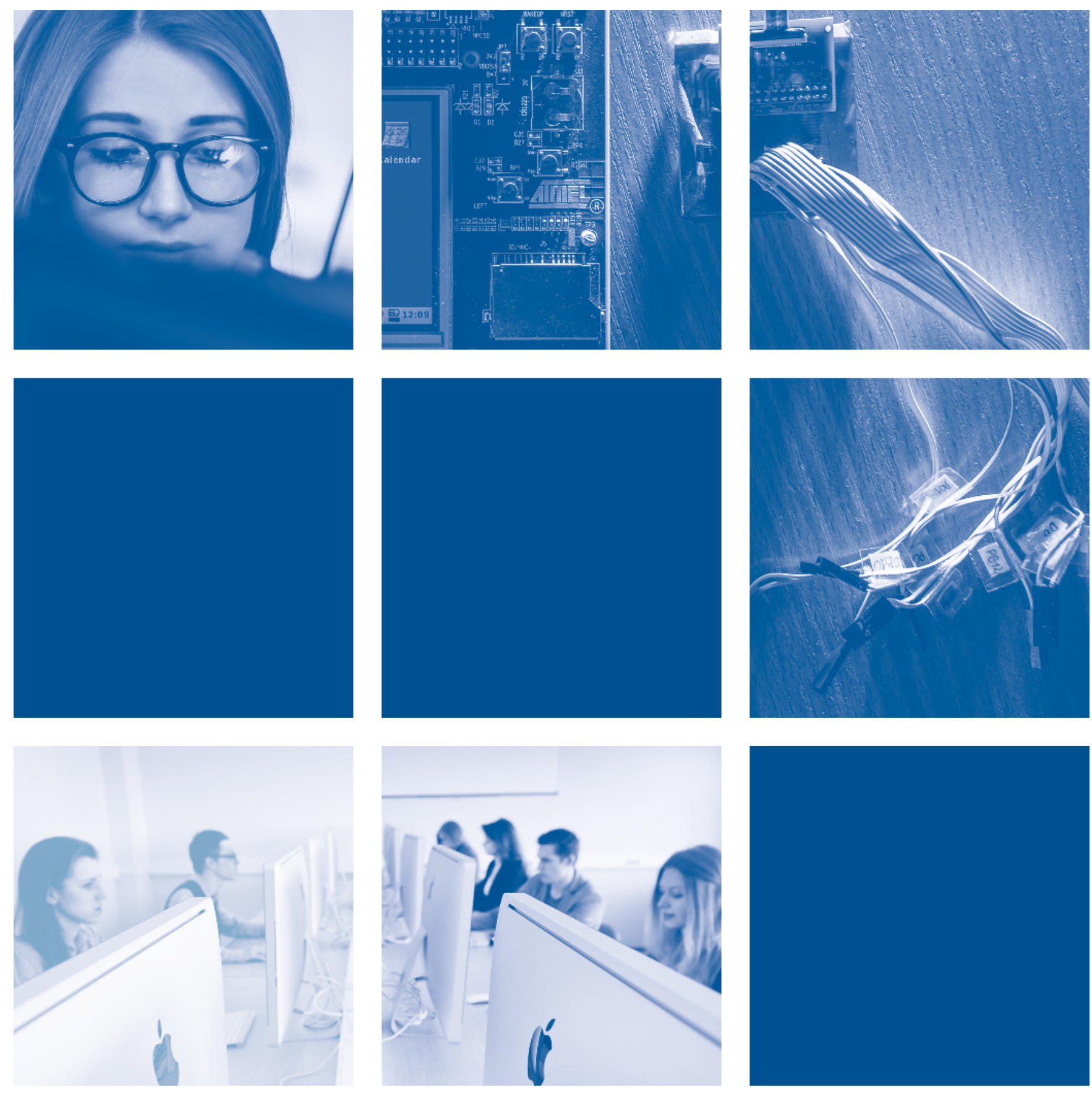



\section{Administravimas ir ištekliai}

\subsection{Prioritetai ir plètra $2014 \mathrm{~m}$.}

Pagrindinis VGTU veiklos prioritetus 2014 metams nustatantis dokumentas yra 2014-2016 metu strateginis veiklos planas. Jame nustatytas administravimo ir ištekliu plètros prioritetas - sukurti efektyvią mokslo ir studijų infrastruktūrą optimizuojant ir atnaujinant turimus išteklius, tobulinti nekilnojamojo turto ir ūkio infrastruktūros valdymą, ugdyti personalą pagrindiniams universiteto tikslams pasiekti, plètoti profesinio tobulèjimo sistemą, puoselèti studentų ir darbuotojų kultūrą, užtikrinti lygias galimybes. Šiam prioritetui vykdyti naudojamos valstybės biudžeto, nuosavos ir tikslinės lěšos. Pagrindiniu $2014 \mathrm{~m}$. infrastruktūros plètros prioritetu, kuriam igyvendinti buvo naudojami visi minèti finansavimo šaltiniai, buvo VGTU Mokslo ir administracijos centro statyba. Skirtingu finansavimo šaltinių sujungimas labai paspartino pastato statybas, o pirmasis statybos etapas - Transporto ir civilinès inžinerijos mokslo ir studijų korpuso statyba - priartėjo prie pabaigos. Naudojant Valstybės biudžeto lèšas 2014 m. buvo užtikrinamas efektyvus universiteto administravimas ir valdymas, didinama darbuotojų kompetencija, atnaujinama ir plečiama VGTU mokslo ir studijų infrastruktūra, tęsiami Architektūros rūmų rekonstravimo darbai. Naudojant tikslinio finansavimo ir nuosavas lěšas 2014 m. buvo atnaujinama infrastruktūra ir ištekliai - užbaigtas projektavimas ir prasidejjo Antano Gustaičio aviacijos instituto Treniruoklių ir laboratorijų korpuso rekonstravimas, VGTU ir Edinburgo Neipiero universitetų produktų dizaino, inovacijų ir kūrybinių industrijų centro „LINK MENŲ fabrikas“ pastato kapitalinis remontas, isibėgejjo Elektronikos, Mechanikos ir Transporto inžinerijos fakultetų laboratorijų korpuso, Elektronikos fakulteto mokomojo korpuso bei Mechanikos ir Transporto inžinerijos fakultetų mokomojo korpuso projektavimas, atnaujinami bibliotekos fondai, vykdoma leidinių leidyba, gerinamas universiteto valdymas - tobulinama VGTU ir universitetinių studijų ir (arba) mokslo padalinių veiklos strateginio planavimo sistema, gerinamos darbo sąlygos ir žmogiškujų išteklių kokybè, plètojama kokybės vadybos sistema, tobulinama VGTU informacinè sistema.

\subsection{Kokybès vadybos sistemos diegimas}

2014 m. toliau buvo diegiama kokybès vadybos sistema. Pagrindinis sistemos tikslas - užtikrinti efektyvu ir rezultatyvų vadybos priemonių naudojimą siekiant padidinti universiteto teikiamų paslaugų kokybę.

Kokybès vadybos sistemos modeli sudaro strateginiai valdymo procesai, pagrindinès veiklos procesai ir pagalbiniai procesai, kurie prisideda prie pagrindinių procesų kuriamos vertès universitetui (6.1 pav.).

Remiantis sukurto kokybės vadybos sistemos modeliu buvo vykdomi sistemos diegimo darbai: buvo detalizuojami sistemą sudarantys procesai, ịvardyti procesus reglamentuojantys vidaus ir išorès teisès aktai, nustatyti procesus matuojantys rodikliai. Diegimo etape projekto igyvendinimo grupè surengè per 50 susitikimų su universiteto vadovybe, administracijos direkcijų ir skyrių bei trijų fakultetų - Architektūros, Statybos ir Verslo vadybos - darbuotojais.

Diegiant kokybės vadybos sistemą universitete bei fakultetuose ir universitetiniuose mokslo centruose buvo paskirti vadovybès atstovai kokybei.

Kokybės vadybos skyriaus iniciatyva bendradarbiaujant su Informacinių technologijų ir sistemų centro darbuotojais bei išorès konsultantais, buvo sukurtas kokybės vadybos sistemos (KVS) informacinio modulio projektas. Siekiama, kad šis informacinis modulis taptų pagrindine sistemos valdymo priemone, apimančia svarbiausius elementus: procesus, dokumentus ir rodiklius.

Ruošiantis sertifikuoti kokybès vadybos sistemą, parengti sistemą reglamentuojančių teisès aktu projektai: kokybės politikos gairès, vidaus audito atlikimo, neatitikčių valdymo procedūrų aprašai ir vadovybinės vertinamosios analizės vykdymo aprašas. Nustatyti universiteto veiklos kokybės tikslai 2015-2016 metams, parengtas Kokybės vadovo projektas. Kokybės vadybos sistemą sertifikuoti planuojama $2015 \mathrm{~m}$.

2014 m. universitete diegiant kokybės vadybos sistemą buvo pasinaudota projekto „VGTU vidinès studiju kokybės vadybos sistemos diegimas“ igyvendinimu. Vykdant projektą 2014 m. universiteto bendruomenei buvo organizuoti mokymai temomis „ISO 9001 standarto reikalavimai ir ju igyvendinimas aukštajame moksle“ 


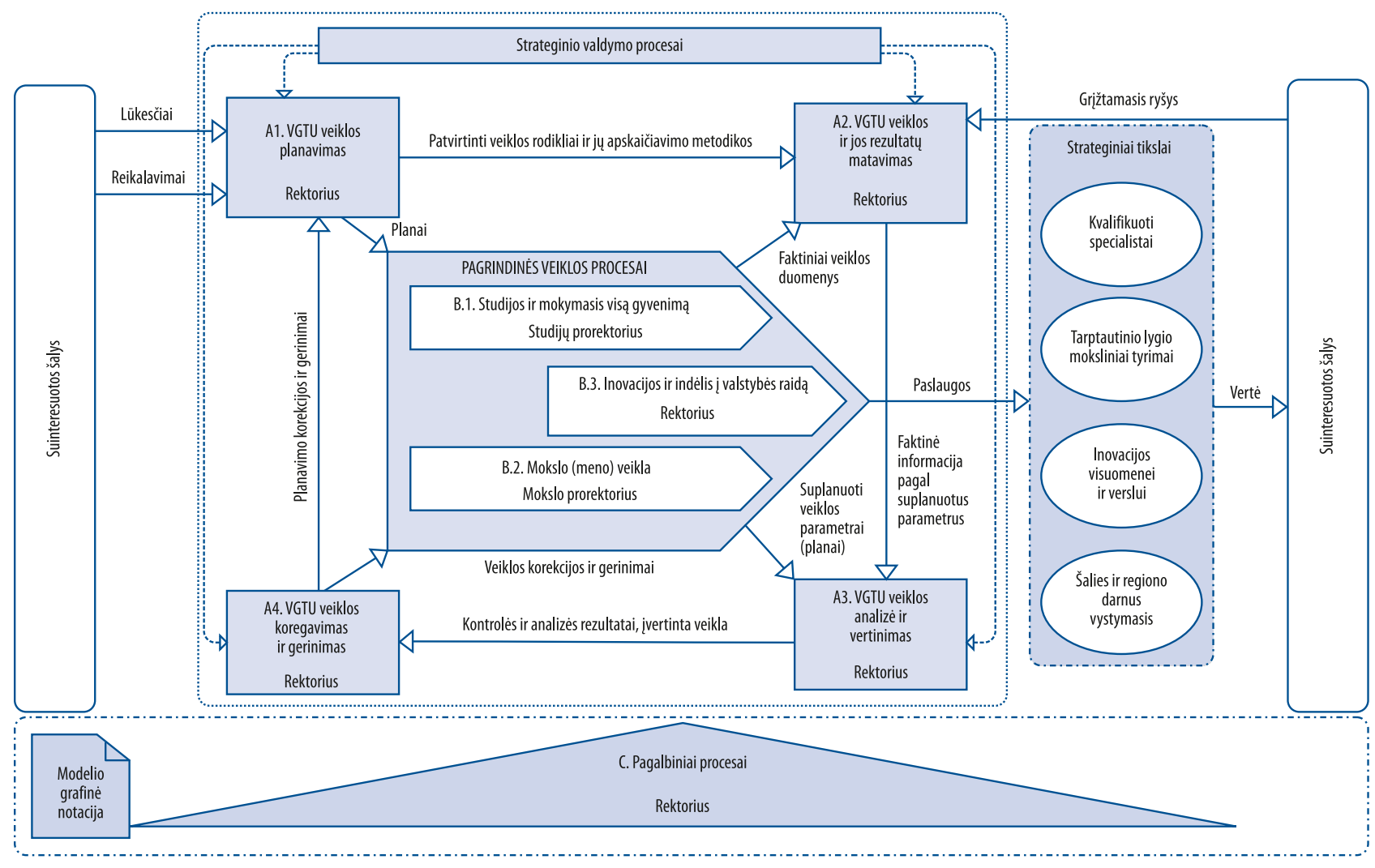

6.1 pav. VGTU kokybès vadybos sistemos modelis

ir „Kokybės vidaus audito principai ir nauda igyvendinant vadybos sistemas“. Mokymu metu darbuotojai supažindinti su ISO 9001 standarto principais ir reikalavimais, aptarta teikiama nauda organizacijai, praktiškai pasirengta atlikti vidaus kokybės auditus, pagal nustatytą tvarką juos dokumentuoti. Vykusių tęstiniu mokymu metu buvo akcentuojamas procesinis požiūris i universiteto vykdomą veiklą. Būtent šis principas sudaro salygas nustatyti ir eliminuoti vertès nekuriančias veiklas, juo pagrista visa kokybès vadybos sistema. 2014 m. igyvendinant minètą projektą ir siekiant pasinaudoti Vakarų Europos aukštujų mokyklu geraja praktika, universiteto atstovu delegacijos lankèsi Liublianos (Slovenija) ir Aalto (Suomija) universitetuose. Šios aukštosios mokyklos yra pasiekusios aukštą tarptautini pripažinimą ir sẻkmingai idiegusios kokybès vadybos sistemas.

Kokybės vadyba organizacijoje neatsiejama nuo socialinès atsakomybės idejjos - kai organizacija suvokia atsakomybę už jos sprendimu ir veiklos itaką aplinkai bei visuomenei. 2014 m. Kokybés vadybos skyrius aktyviai dalyvavo universitete rengiant žaliojo universiteto koncepciją.

2014 m. lapkričio mènesi VGTU istojo i Lietuvos kokybès vadybos ir inovaciju asociaciją, vienijančią mokslo, verslo ir viešojo sektoriaus atstovus. VGTU dalyvavimas asociacijos veikloje suteikia galimybę dalytis geraja patirtimi su šios srities specialistais ir ekspertais, dalyvaujant Lietuvos ir užsienio šalių kokybès klubu veikloje.

2014 m. spalio 14 d. Tarybos nutarimu Nr. 4-3 pritarta VGTU struktūriniams pakeitimams - nuo 2015 m. sausio $2 \mathrm{~d}$. Kokybės vadybos skyrius pertvarkytas i Strateginio planavimo, kokybès vadybos ir analizės centrą.

\section{3. Žmogiškieji ištekliai}

Vilniaus Gedimino technikos universiteto 2014-2020 metụ plètros strategijoje numatomos priemonės pagrindiniams universiteto tikslams siekti:

- Aktyvaus personalo, gebančio dirbti tarptautinèje aplinkoje ir tarptautiniu lygiu ugdymas.

- Akademinès lyderystès skatinimas.

- Akademinès karjeros sistemos, užtikrinančios pakankamą aukščiausio lygio mokslininku potencialą ir jaunų talentu paiešką bei jų palanku karjeros kelia, tobulinimas.

- Mokslinio ir pedagoginio personalo rengimas doktorantūroje.

- Profesinio tobulejimo sistemos, apimančios darbuotoju kompetenciju ugdymą, motyvacijos didinimą, mokymosi ir mokymo galimybiu sudarymą, plètra. 
- Akademinès kultūros ir socialinès veiklos puoselèjimas.

- Lygios galimybès dirbti ir kelti kvalifikaciją kiekvienam bendruomenès nariui nepriklausomai nuo lyties, tautybès ar negalios.

Tik kompetentingas, kvalifikuotas, nuolat tobulejantis universiteto personalas gali perteikti studentams naujausias mokslo žinias, parengti aukščiausios kvalifikacijos kūrybiškus, motyvuotus specialistus ir mokslininkus.

Vilniaus Gedimino technikos universiteto personalą 2014 m. gruodžio 31 d. sudarė 1733 darbuotojai. Finansuojami iš biudžetinių lèšu užèmè 1453,87 etato (6.2 pav.). Vilniaus Gedimino technikos universiteto 2014-2016 m. strateginiame veiklos plane numatyta iš biudžetinių lešu finansuoti 1580 pareigybių. Darbuotojų, finansuojamų iš nuosavų ir tikslinių lèšų, buvo 203. Jie užèmè 148,93 etato (6.3 pav.). Toliau mažèjant studentų, universitete atitinkamai mažèjo dėstytojų ir jų užimamų etatų skaičius (4,40 \%) (6.4 ir 6.5 pav.).

Mokslo darbuotojų ir kitų tyrèjų skaičiaus mažejjimas sietinas su naujais finansavimo programų periodais (inicijuojami nauji kvietimai teikti paraiškas paramai gauti). Kitu personalo grupių užimamų etatų skaičius sumažèjo 6,48 \%. Didesnè dalis universiteto dėstytojų priklauso amžiaus grupèms iki 30 metų, 31-35 ir 36-40 metu (6.1 lentelè).

Vidutinis dėstytojų ir mokslo darbuotojų amžius išliko panašus - 45 ir 42 metai (6.6 ir 6.7 pav.). Kitų personalo grupių vidutinis amžius - 45 metai. Lyginant 2013 ir 2014 metus, universitete suteikta beveik du kartus daugiau pedagoginių profesoriaus ir docento mokslo vardų (6.8 pav.). Šiuo metu universitetas nesusiduria su personalo senėjimo problema, dirbančiuju amžiaus vidurkis nesiekia 50 metų.

Dėstytojų, turinčių mokslo laipsnị, skaičius nuo visų dėstytojų skaičiaus sudaro 73,26 \% (6.2 lentelè). Šis dydis viršija 2014-2016 m. Vilniaus Gedimino technikos universiteto strateginiame veiklos plane numatyta $66 \%$ kriteriju.

Akademinis personalas kvalifikaciją tobulino stažuotėse, mokymuose, dalyvavo tarptautinėse ir nacionalinėse mokslo konferencijose ir profesinès veiklos klausimams skirtose paskaitose. Administracijos ir kitas personalas dalyvavo ivairiuose mokymuose, organizuotuose igyvendinant ES struktūrinès paramos projektus, mokymuose pagal Erasmus programą bei kitų institucijų organizuotuose mokymuose, seminaruose (6.9 ir 6.10 pav.).

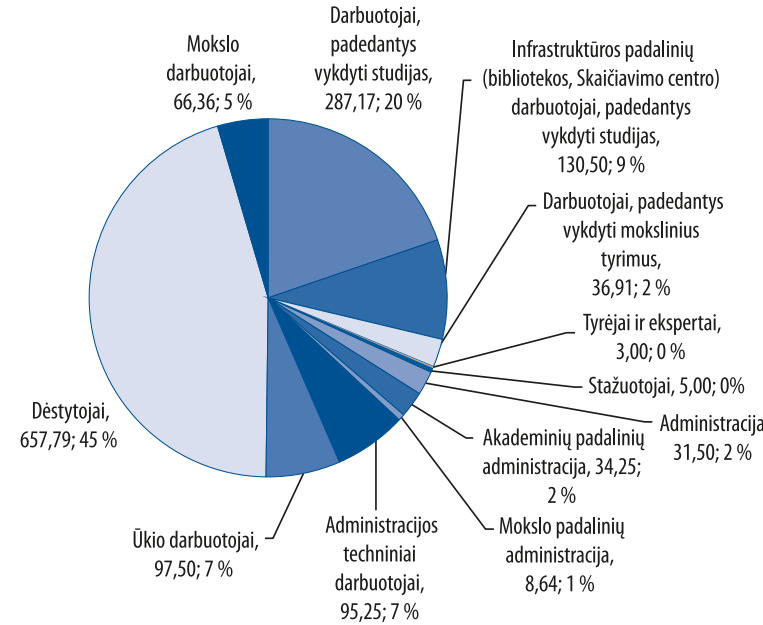

6.2 pav. Vilniaus Gedimino technikos universiteto etatų, finansuojamu iš biudžetiniu lèšu, struktūra

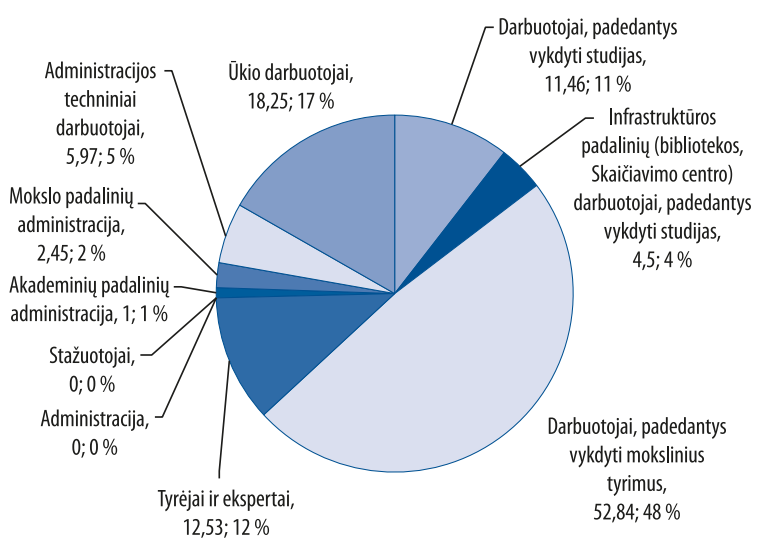

6.3 pav. Vilniaus Gedimino technikos universiteto etatų, finansuojamu iš nuosavu ir tiksliniu lèšu, struktūra

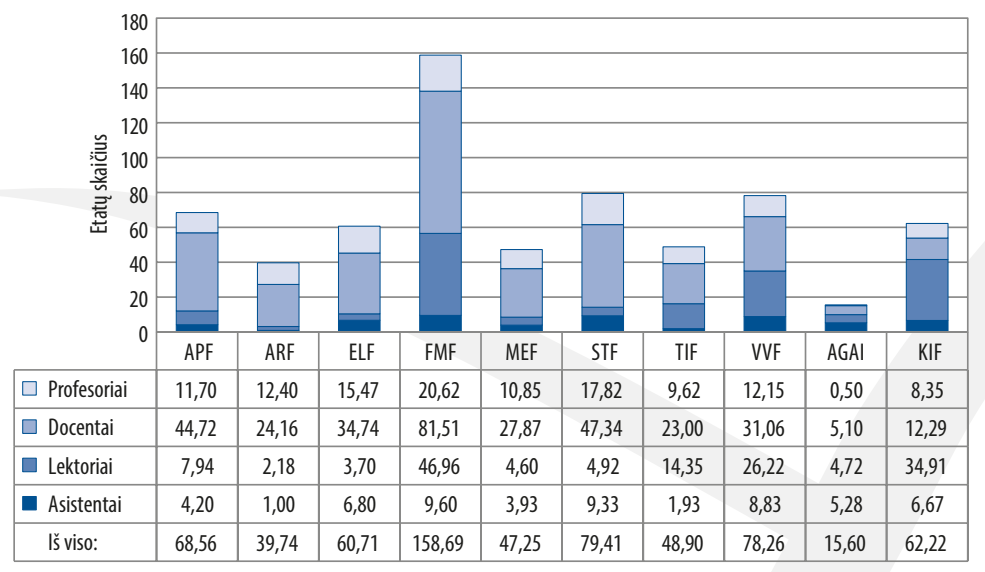

6.4 pav. Dėstytoju užimamu etatu skaičius pagal fakultetus 20141231 


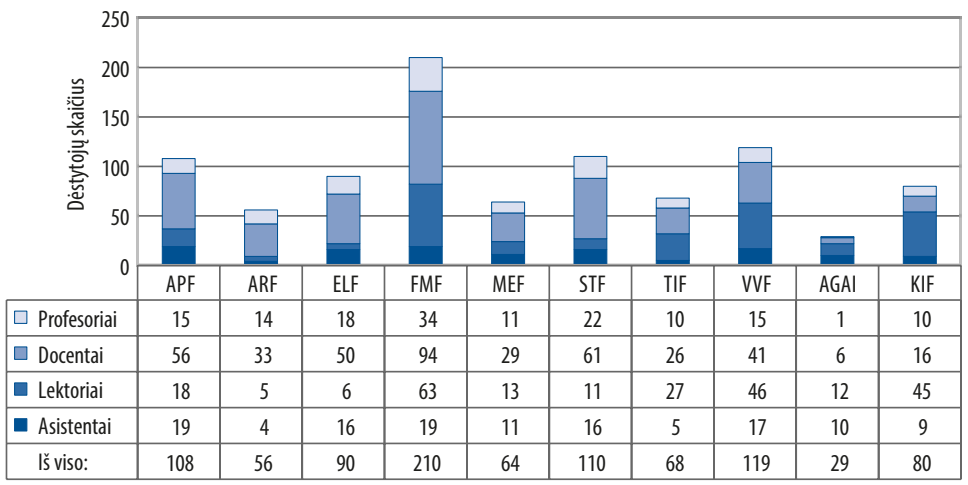

6.5 pav. Dėstytoju skaičius pagal fakultetus 20141231

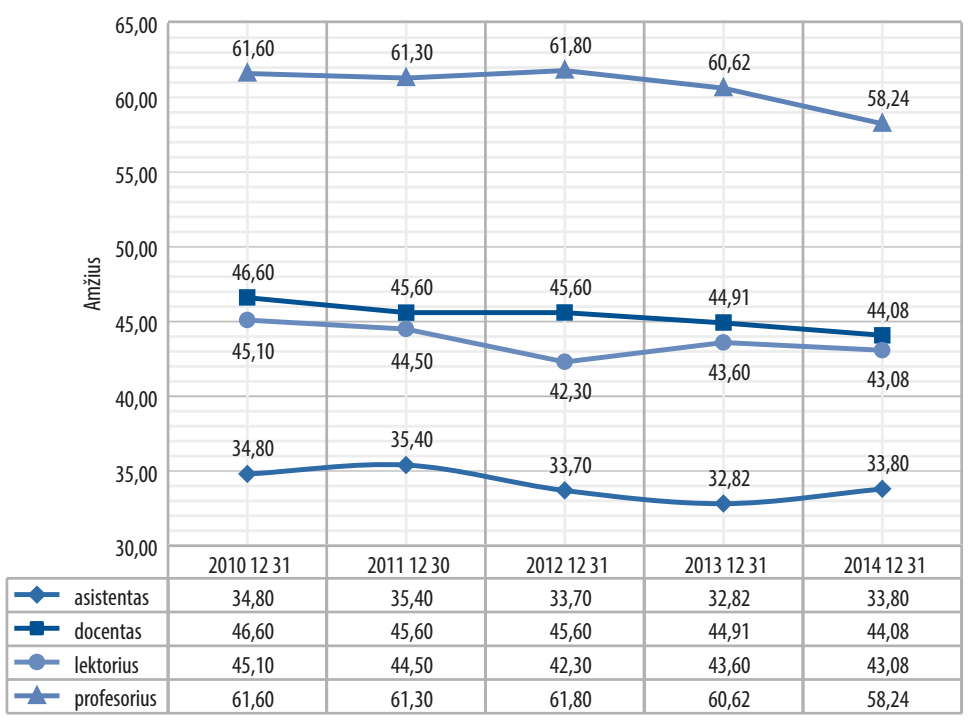

6.6 pav. Dėstytojų amžiaus kitimas 2010-2014 m

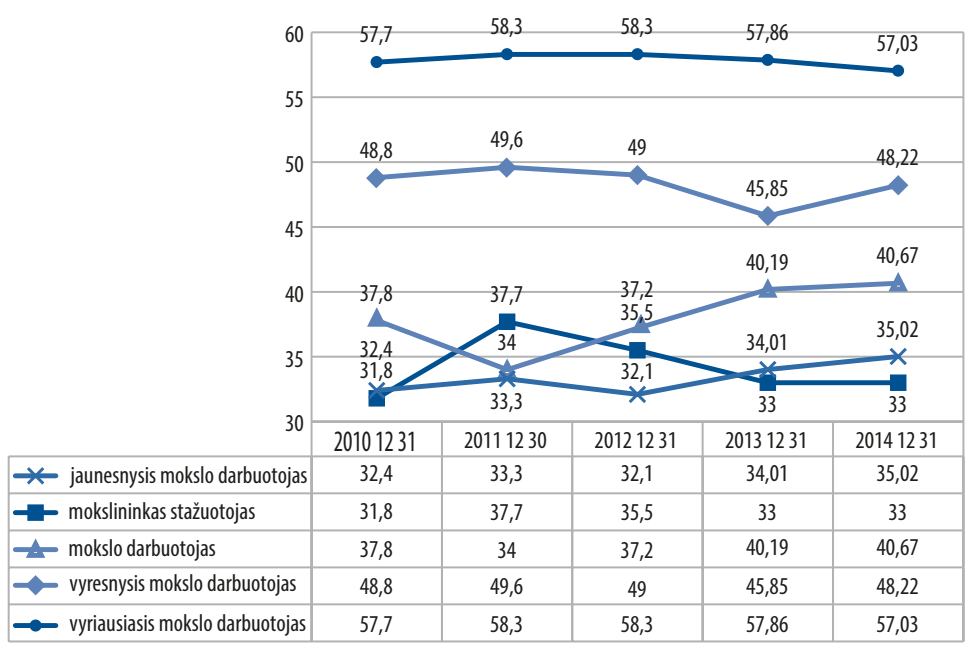

6.7 pav. Mokslo darbuotojų amžiaus kitimas 2010-2014 m. 


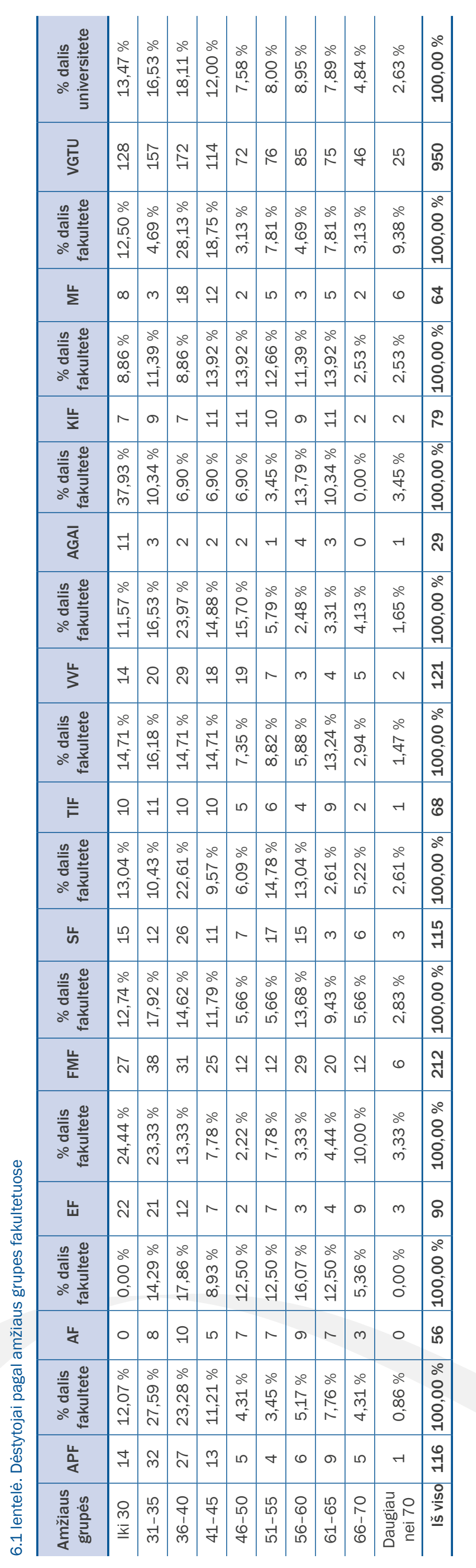




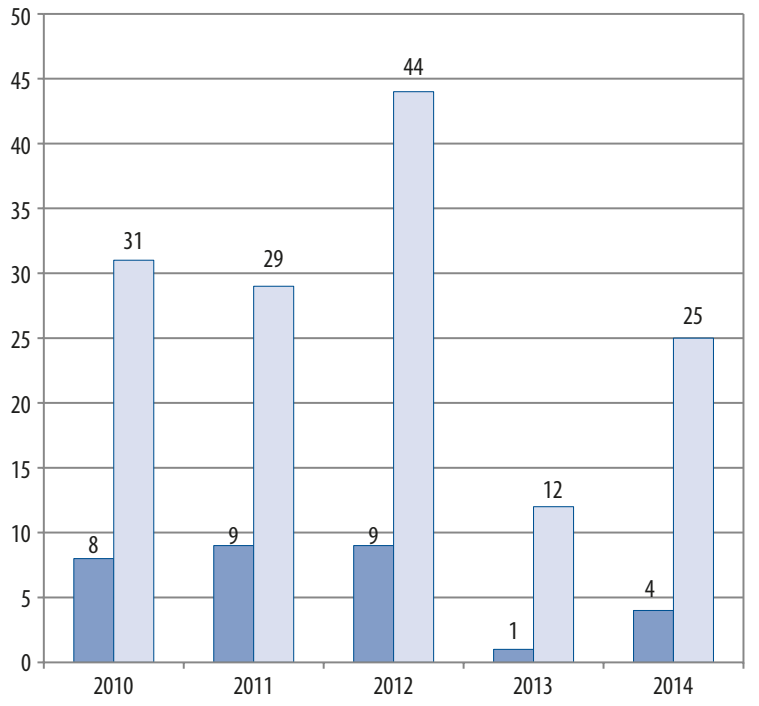

$\square$ Pedagoginis profesoriaus vardas $\square$ Pedagoginis docento vardas

6.8 pav. VGTU suteikti pedagoginiai vardai 2010-2014 m.

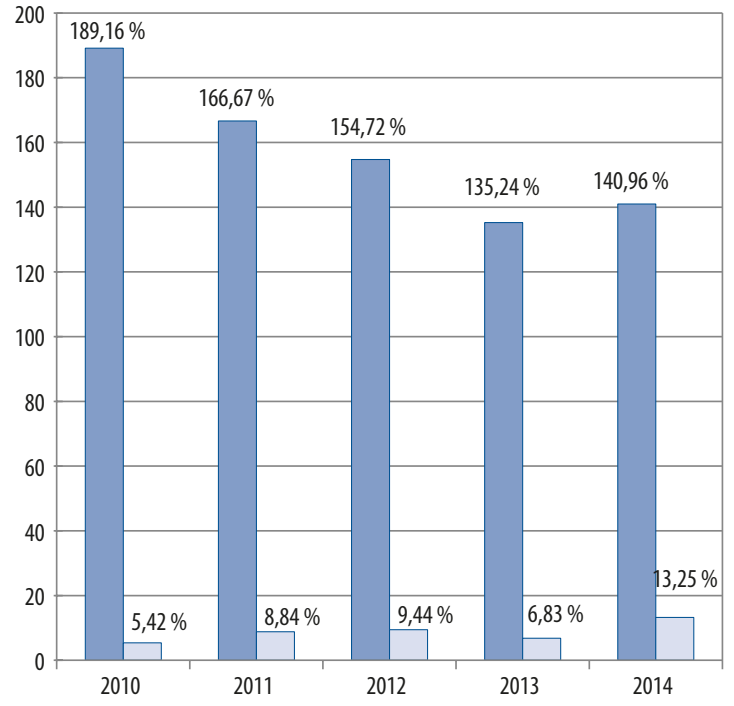

$\square$ Universiteto organizuotose konferencijose $\quad \square$ Užsienio konferencijose

6.9 pav. Dėstytoju ir mokslo darbuotoju, dalyvavusiu mokslo konferencijose, skaičiaus dalies kitimas 2010-2014 m.

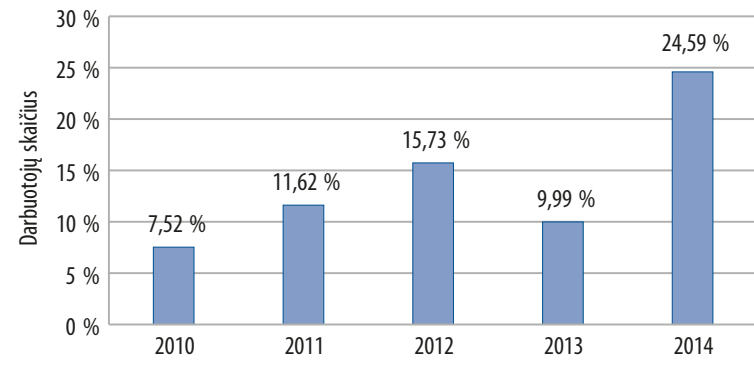

6.10 pav. Seminaruose ir mokymuose kvalifikaciją kèlusių administracijos ir kito personalo darbuotoju procentinè skaičiaus dalis

6.2 lentelè. VGTU dėstytojų, turinčių mokslo laipsnį, etatų skaičiaus kitimas

\begin{tabular}{|c|c|c|c|c|c|c|}
\hline & 20091231 & 20101231 & 20111230 & 20121231 & 20131231 & 20141231 \\
\hline \% nuo viso dėstytojų skaičiaus & $72,40 \%$ & $72,30 \%$ & $69,80 \%$ & $68,50 \%$ & $67,64 \%$ & $73,26 \%$ \\
\hline
\end{tabular}

6.3 lentelè. Dėstytojai, išvykę i pedagogines stažuotes 2010-2014 m.

\begin{tabular}{|c|c|c|c|c|c|c|c|}
\hline Eil. Nr. & Fakultetas & $2010 \mathrm{~m}$. & $2011 \mathrm{~m}$. & $2012 \mathrm{~m}$. & $2013 \mathrm{~m}$. & $2014 \mathrm{~m}$. & Iš viso \\
\hline 1 & APF & 0 & 1 & 6 & 4 & 4 & 15 \\
\hline 3 & ELF & 2 & 1 & 3 & 6 & 4 & 16 \\
\hline 4 & FMF & 1 & 1 & 1 & 1 & 3 & 7 \\
\hline 6 & STF & 8 & 8 & 9 & 7 & 6 & 38 \\
\hline 7 & TIF & 3 & 5 & 2 & 3 & 4 & 17 \\
\hline 8 & VVF & 10 & 7 & 4 & 7 & 4 & 32 \\
\hline 9 & AGAI & 0 & 0 & 0 & 0 & 0 & 0 \\
\hline
\end{tabular}




\subsection{Ekonomika ir finansu valdymas}

\section{Pagrindiniai finansavimo bruožai}

Vilniaus Gedimino technikos universiteto veikla finansuojama iš keturių šaltinių: valstybès biudžeto asignavimų, nuosavų lèšu (pajamų už suteiktas paslaugas), tikslinio finansavimo lèšų ir paramos lèšų. Pagrindinis universiteto finansavimo šaltinis - valstybės biudžeto asignavimai - sudarė 52,5 proc. bendros 2014 m. iplaukų sumos.

Lietuvos universitetams 2014 m. mokslo ir studijų išlaidoms buvo skirta 599,7 mln. Lt valstybės biudžeto asignavimų, iš jų VGTU - 69,0 mln. Lt, arba 11,5 proc. Aukštosioms mokykloms skirtas finansavimas, palyginti su praèjusiais metais, sumažèjo 8,7 proc. VGTU skirtos lèšos išlaidoms sumažèjo 7,3 proc. Praèjusiais, kaip ir ankstesniais, metais universitetams skirti valstybès biudžeto asignavimai buvo nepakankami visoms veiklos sąnaudoms padengti.

Papildomos universiteto pajamos gaunamos už suteiktas mokslo, studijų, ūkio ir kitas paslaugas. Tikslinio finansavimo pajamos gaunamos dalyvaujant ivairiuose projektuose ir programose, kurios finansuojamos iš valstybės biudžeto, Europos Sajungos struktūrinių fondų ir kitu šaltinių.

Valstybės biudžeto asignavimai 2014 m. universitetams skirti Lietuvos Respublikos 2013 m. gruodžio 12 d. valstybės biudžeto ir savivaldybių biudžetų finansinių rodiklių patvirtinimo įstatymu Nr. XII-659 ir paskirstyti pagal vykdomas programas Lietuvos Respublikos Vyriausybės 2014 m. vasario 12 d. nutarimu Nr. 137 „Dèl 2014 metu Lietuvos Respublikos valstybès biudžeto asignavimų paskirstymo pagal programas“ bei Lietuvos Respublikos švietimo ir mokslo ministro 2014 m. spalio 21 d. jsakymu Nr. V-936.

Valstybės biudžeto asignavimai skiriami programiniu principu, atsižvelgiant i valstybès finansuojamų studentų skaičių (nuo 2009 m. - atsižvelgiant i stojimo rezultatus) ir mokslinès veiklos rezultatus, vadovaujantis Lietuvos Respublikos Vyriausybės 2009 m. gegužès 13 d. nutarimu Nr. 402 „Dèl Norminiu studijų krypties (studiju programų grupės) studijų kainų apskaičiavimo ir Lietuvos Respublikos valstybės biudžeto lėšu studiju kainai valstybės finansuojamose studiju vietose apmokèti skyrimo tvarkos aprašo ir Lietuvos Respublikos valstybės biudžeto lěšų skyrimo asmenų, priimtų i valstybines aukštąsias mokyklas iki 2009 metu, studijoms finansuoti tvarkos aprašo patvirtinimo“ (Žin., 2009 m., Nr. 59-2292). Asignavimai kiekvienai aukštajai mokyklai buvo nustatyti atskirai studijoms organizuoti, moksliniams tyrimams vykdyti bei ūkiui ir administravimui. Tačiau, vadovaujantis Mokslo ir studiju istatymo 67 str. 2 dalies nuostatomis, aukštosioms mokykloms valstybès biudžeto asignavimai buvo skirti kaip bendra suma išlaidoms finansuoti, t. y. aukštosios mokyklos pačios turejjo teisę nustatyti, kiek ir kuriai sričiai skirti gautų asignavimų. Pagal minètą metodiką VGTU nuo 2009 m. rudens buvo skirti valstybès biudžeto asignavimai 2010-2014 m. (6.4 lentelè).

2014 m. universitetui valstybės biudžeto asignavimai išlaidoms buvo skirti pagal dvi universiteto strateginio veiklos plano programas:

1. Aukščiausios kvalifikacijos specialistų rengimas ir mokslo tyrimo plètra (kodas 0101 ) - 65764 tūkst. Lt.

2. Studentų rẻmimas (kodas 0102 ) - 4189 tūkst. Lt.

Kapitalo investicijoms Aukščiausios kvalifikacijos specialistų rengimas ir mokslo tyrimo plètros programai (kodas 0101 ) 2014 m. VGTU iš valstybès biudžeto skirta 2500 tūkst. Lt statybai ir pastatams renovuoti.

6.4 lentelè. Valstybès biudžeto asignavimai 2010-2014 m. pagal veiklos sritis

\begin{tabular}{|c|c|c|c|c|c|}
\hline \multirow{2}{*}{ Veiklos sritis } & \multicolumn{5}{|c|}{ Skirtas finansavimas, tūkst. Lt } \\
\hline & $2010 \mathrm{~m}$. & $2011 \mathrm{~m}$. & $2012 \mathrm{~m}$. & $2013 \mathrm{~m}$. & $2014 \mathrm{~m}$. \\
\hline Studijoms & 42117 & 56763 & 57124 & 56258 & 52261 \\
\hline $\begin{array}{l}\text { AGAl skrydžių ir skrydžių valdymo } \\
\text { praktikoms }\end{array}$ & 1371 & 1371 & 1371 & 1371 & 931 \\
\hline Ūkiui ir administravimui & 8812 & 6007 & 5844 & 5456 & 6063 \\
\hline Stipendijoms, iš jų & 7251 & 6752 & 5806 & 5077 & 4189 \\
\hline I, II pakopos studentams & 3961 & 3739 & 3113 & 2772 & 2144 \\
\hline
\end{tabular}


2010-2014 m. VGTU skirtų valstybės biudžeto asignavimų išlaidoms dinamika pavaizduota 6.11 pav.

Vienam valstybès finansuojamam universiteto studentui 2014 m. teko 8,5 tūkst. Lt, skirtų valstybės biudžeto asignavimų išlaidoms (be stipendijų).

2014 m. iš Studentų rèmimo programos lèšu gavo stipendijas 1438 studentai, planas ivykdytas 106,5 proc. Taip pat pasiektas studentu rẻmimo programos tikslo - teikti studentams finansinę paramą - rezultato kriterijus: 13,6 proc. pirmosios, antrosios pakopos ir vientisujų studijų studentu gavo stipendijas vietoje planuotu 13 proc.

Viena aktualiausių problemų išlieka VGTU AGAl finansavimas, t. y. orlaivių pilotavimo ir skrydžių valdymo studijų programų studentų praktinis rengimas. Vadovaujantis 2014 m. gegužès 30 d. Lietuvos Respublikos švietimo ir mokslo ministro įsakymu Nr. V-481 „Dèl Lietuvos Respublikos valstybės biudžeto lèšų skyrimo valstybinèms mokslo ir studijų institucijoms sudėtingos infrastruktūros objektams finansuoti 2014 metais tvarkos aprašo patvirtinimo“, VGTU skirta 931 tūkst. Lt valstybės biudžeto asignavimų AGAl skrydžių praktikų bazės eksploatavimo išlaidoms apmokèti.

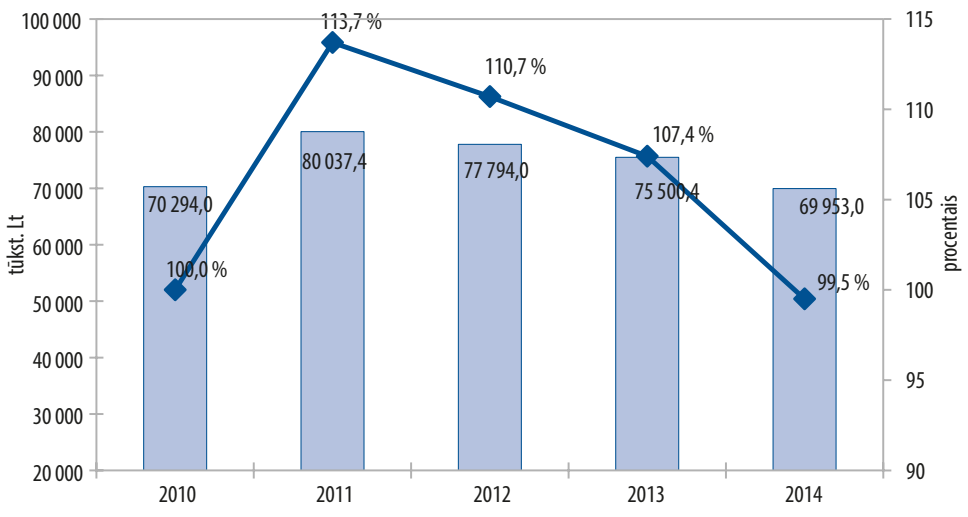

6.11 pav. Valstybės biudžeto asignavimai išlaidoms 2010-2014 m.

Pagrindiniai bendrieji biudžeto sudarymo principai, kuriuos buvo siekiama igyvendinti, yra išlaidų tikslingumas, skaidrumas ir efektyvumas. Formuojant VGTU biudžetą, buvo laikomasi ir lèšu skyrimo pagal funkcijas bei atsakingus administratorius (fondų valdytojus) principų.

Pasirengimas naujos valiutos - euro - jvedimui buvo didelis iššūkis Finansų direkcijos ir Informacinių technologijų ir sistemų centro specialistams, pertvarkant VGTU informacinę ir finansų apskaitos sistemas.

\section{Iplaukos}

2014 m. Vilniaus Gedimino technikos universitetas gavo 138 023,6 tūkst. Lt bendrujų ịplaukų, arba 3,1 proc. mažiau negu 2013 m. (6.5 lentelè). Bendruju iplaukų struktūra pateikta 6.12 pav.

Praejjusiais metais keitèsi ir iplaukų struktūra - iš viso gauta 72453 tūkst. Lt planinių valstybès biudžeto asignavimu išlaidoms ir turtui įsigyti, t. y. 5,4 \% mažiau negu 2013 m., o už universiteto teikiamas paslaugas ịplaukų gauta 4 \% daugiau nuosavų lèšų. Tiksliniam finansavimui gautos ịplaukos 2014 m. sumažèjo 5,1 \%. Gauta parama kol kas sudaro nedidelę dali iš bendros iplaukų sumos, 2014 m. jos buvo gauta 209,4 tūkst. Lt (6.5 lentelè).

Nuo mokslo ir studijų reformos pradžios per pastaruosius trejus metus sumažèjo valstybės finansuojamų studentų skaičius daugumoje valstybinių universitetinių aukštujų mokyklų, kartu ir valstybės biudžeto bendrieji asignavimai išlaidoms. Šios rūšies finansavimo mažejimas universitetą priverčia spręsti kvalifikuoto personalo ir universiteto infrastruktūros išlaikymo problemas, ieškant papildomo finansavimo iš kitų šaltinių.

Esant nepakankamam finansavimui iš valstybės biudžeto, labai svarbu ieškoti kitu finansavimo šaltinių, gauti kitų papildomų pajamų. Praejjusiais metais pavyko gauti 65 570,6 tūkst. Lt kitų - ne valstybės biudžeto pajamų (6.5 lentelè). Šios papildomos ịplaukos sudarè $47,5 \%$ visų bendrujų universiteto ịplaukų - pasiektas aukščiausios kvalifikacijos specialistų rengimo ir mokslo tyrimų plètros programos tikslo rezultato kriterijus (planuota 40 proc.). Kaip matyti iš 6.5 lentelès, vis dèlto didžiausią kitų papildomų pajamų dali sudarè studijų nuosavų lèšu ịplaukos (30 \%) ir ES struktūrinių fondų léšos - 20 135,3 tūkst. Lt (30,7 \%).

VGTU 2014 m. planavo gauti 30784,2 tūkst. Lt nuosavų lèšų iplaukų. Šių lèšu surinkimo planas buvo sẻkmingai ìvykdytas, gauta 35 585,3 tūkst. Lt ịplaukų, planas ịvykdytas 115,6 \%. 2014 m. gruodžio 31 d. liko nepanaudotas 10 154,4 tūkst. Lt universiteto nuosavų lèšų likutis. Šios lèšos bus naudojamos 2015 m. universiteto veiklos poreikiams finansuoti. 2014 m. nuosavų lèšų, gautų už universiteto teikiamas paslaugas, struktūra pavaizduota 6.13 pav. 
6.5 lentelè. VGTU bendrosios ịplaukos, tūkst. Lt

\begin{tabular}{|c|c|c|c|c|}
\hline Eil. Nr. & Iplaukos & $2013 \mathrm{~m}$. & $2014 \mathrm{~m}$. & Pokytis, \% \\
\hline 1 & Valstybès biudžeto asignavimai & 76600,4 & 72453 & $-5,4$ \\
\hline 1.1 & $\begin{array}{l}\text { Aukščiausios kvalifikacijos specialistu rengimas ir mokslo tyrimu } \\
\text { plètros programa }\end{array}$ & 71523,4 & 68264,0 & $-4,6$ \\
\hline 1.2 & Studentų rèmimo programa & 5077,0 & 4189,0 & $-17,5$ \\
\hline 2 & Nuosavos lèšos (už teikiamas paslaugas) & 34201,9 & 35585,3 & 4,0 \\
\hline 2.1 & Studijų proceso palaikymo programa, iš ju iplaukos už: & 17727,0 & 19671,3 & 11,0 \\
\hline 2.1 .1 & studijų i̇mokas & 16292,0 & 18421,2 & 13,1 \\
\hline 2.1.2 & kvalifikacijos kèlimo ir kitus kursus & 902,1 & 730,2 & $-19,1$ \\
\hline 2.1 .3 & registracijos i studijas mokestị ir kitas studijų paslaugas & 532,9 & 519,9 & $-2,4$ \\
\hline 2.2 & $\begin{array}{l}\text { Mokslo tyrimu ir technologijų plètros bei doktorantūros programa, } \\
\text { iš ju iplaukos už: }\end{array}$ & 11245,0 & 9742,6 & $-13,4$ \\
\hline 2.2 .1 & užsakomuosius MTD, mokslinę veiklą ir kt. paslaugas & 8411,1 & 8371,9 & $-0,5$ \\
\hline 2.2 .2 & konferencijas, seminarus ir kt. & 836,9 & 785,7 & $-6,1$ \\
\hline 2.2 .3 & tarptautinius mokslo programu projektus* & 1997,0 & 585,0 & $-70,7$ \\
\hline 2.3 & Ūkio ir administravimo programa, iš ju iplaukos už: & 5229,9 & 6171,4 & 18,0 \\
\hline 2.3 .1 & studentų apgyvendinimo paslaugas bendrabučiuose & 4607,6 & 5378,1 & 16,7 \\
\hline 2.3 .2 & patalpų ir i̊rangos nuomą & 361,4 & 402,5 & 11,4 \\
\hline 2.3.3 & kitas paslaugas & 260,9 & 390,8 & 49,8 \\
\hline 3 & Tikslinès paskirties lěšos (pavedimų), iš jų: & 31375,9 & 29775,9 & $-5,1$ \\
\hline 3.1 & ES struktūrinių fondų lěšos & 19134,4 & 20135,3 & 5,2 \\
\hline 3.2 & Lietuvos mokslo Tarybos lèšos & 1825,1 & 1468,1 & $-19,6$ \\
\hline 3.3 & Mokslo, inovacijų ir technologiju agentūra & 771,5 & 579,9 & $-24,8$ \\
\hline 3.4 & $\begin{array}{l}\text { Mokymosi visa gyvenimą programai - Erasmus programos } \\
\text { Europos Komisijos léšos }\end{array}$ & 2756,6 & 3233,2 & 17,3 \\
\hline 3.5 & Erasmus programai vykdyti Švietimo mainų ir paramos fondo léšos & 697,7 & 893,3 & 28,0 \\
\hline 3.6. & Tarptautinių programų lèšos, iš jų: & 5110,1 & 2743,2 & $-46,3$ \\
\hline 3.6 .1 & studijų projektai & 3794,0 & 1723,3 & $-54,6$ \\
\hline 3.6.2 & mokslo projektai & 1316,1 & 1019,9 & $-22,5$ \\
\hline 3.7 & Kitų projektų lèšos & 1080,5 & 723,0 & $-33,1$ \\
\hline 4 & Paramos lèšos & 228,1 & 209,4 & $-8,2$ \\
\hline \multicolumn{2}{|r|}{ VGTU gautų asignavimų ir ịplaukų suma iš viso } & 142406,3 & 138023,6 & $-3,1$ \\
\hline
\end{tabular}

* Projektai užbaigti $2014 \mathrm{~m}$.

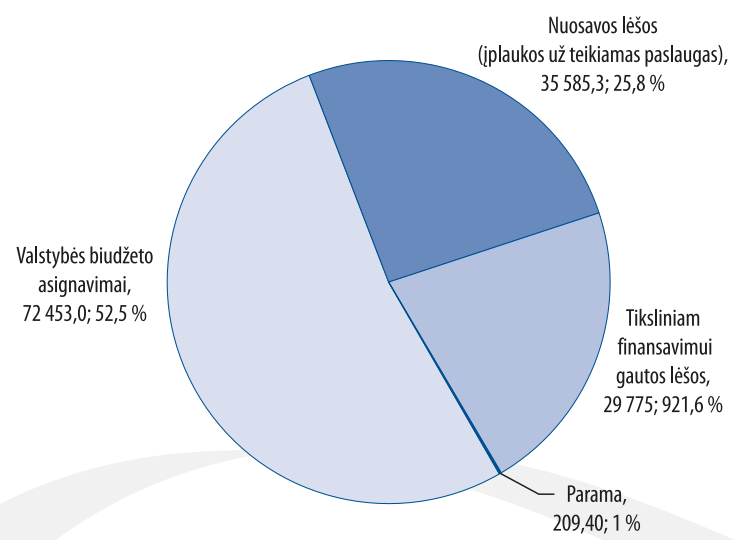

6.12 pav. 2014 metu bendruju iplauku struktūra, tūkst. Lt

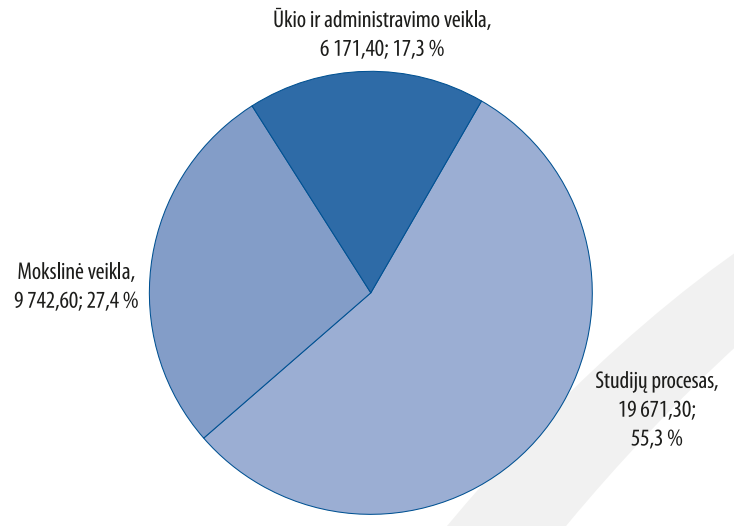

6.13 pav. 2014 m. gautụ nuosavụ lešu (iplaukų už teikiamas paslaugas) struktūra pagal veiklos sritis, tūkst. Lt 


\section{Išlaidos}

2014 m. universiteto bendrosios išlaidos sudare 146 291,1 tūkst. Lt, planas ìvykdytas 88,7%. 2014 m. bendrujų išlaidos struktūra parodyta 6.6 lentelèje.

2014 m. didžiausią VGTU biudžeto asignavimų lèšų išlaidų dali sudarè išlaidos darbo užmokesčiui (67,7 \%), socialinio draudimo ir garantinio fondo imokoms (21,1\%), socialinei paramai, studentu stipendijoms (6\%), kitoms išlaidoms prekèms ir paslaugoms (1,8 \%) bei ilgalaikiam turtui ịsigyti ir kurti (3,5 \%). 2014 m. administravimo išlaidų lyginamoji dalis nuo valstybès biudžeto asignavimų išlaidoms (be stipendijų) sudarè 14,6 proc. vietoje planuotu 13 proc. Programos (kodas 01 01) tikslo - rengti aukščiausios kvalifikacijos specialistus ir mokslininkus, plètoti mokslinius tyrimus - rezultato vertinimo kriterijus neigyvendintas (jvykdytas 87,7 proc.). Administravimo išlaidos yra sąlygiškai pastovus dydis, todèl, 2014 m. sumažejjus programos (kodas 0101 ) finansavimui, dèl sumažèjusio valstybės finansuojamų studentu skaičiaus santykinis administravimo išlaidų ir visos programos dydis viršijo planini.

Nuosavų lèšų naudojimo struktūra pavaizduota 6.14 pav.

6.6 lentelè. 2014 m. VGTU bendrujų išlaidų struktūra pagal lėšų šaltinius

\begin{tabular}{|c|c|c|c|c|c|}
\hline Eil. Nr. & Išlaidos pagal programas & $\begin{array}{l}2014 \text { m. iplaukų } \\
\text { ivykdymas }\end{array}$ & $\begin{array}{l}2014 \text { m. išlaidų } \\
\text { planas }\end{array}$ & $\begin{array}{l}2014 \text { m. išlaidų } \\
\text { ịvykdymas }\end{array}$ & $\begin{array}{c}2014 \text { metų plano } \\
\text { ivykdymas, \% }\end{array}$ \\
\hline 1. & Valstybès biudžeto asignavimai, iš jų: & 72453,0 & 72453,0 & 72453,0 & 100,0 \\
\hline 1.1. & $\begin{array}{l}\text { Aukščiausios kvalifikacijos specialistu } \\
\text { rengimo ir mokslo tyrimu plètros } \\
\text { programa (kodas 01.01), iš jų: }\end{array}$ & 68264,0 & 68264,0 & 68264,0 & 100,0 \\
\hline 1.2.1. & Stipendijos I ir II pakopos studentams & 2144,0 & 2144,0 & 2144,0 & 100,0 \\
\hline 1.2.2. & Stipendijos III pakopos studentams & 2045,0 & 2045,0 & 2045,0 & 100,0 \\
\hline 2. & Nuosavos lèšos (už teikiamas paslaugas) & 35585,3 & 43260,0 & 36519,9 & 84,4 \\
\hline 3. & Tikslinio finansavimo lèšos & 29775,9 & 48591,0 & 37168,5 & 76,5 \\
\hline
\end{tabular}

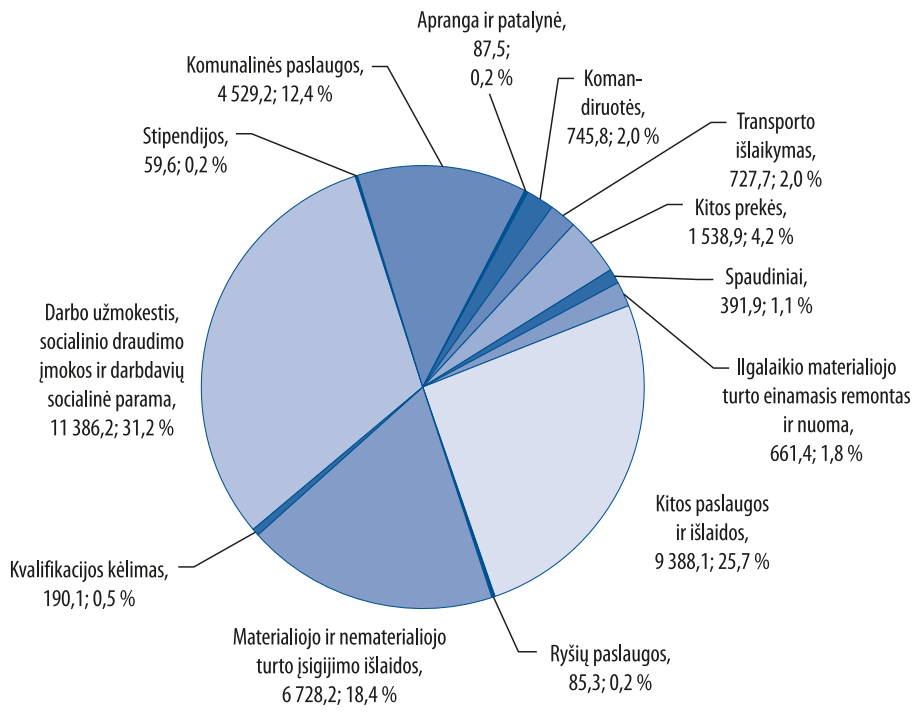

6.14 pav. 2014 m. nuosavų lèšų išlaidų struktūra pagal ekonominès klasifikacijos straipsnius, kasos, tūkst. Lt

Per praèjusius metus panaudojus biudžetines lèšas, 2013 m. nuosavų lėšų likutị ir 2014 m. gautas nuosavų pajamų lěšas, buvo laiku išmokèti atlyginimai darbuotojams ir mokesčiai valstybei. 2014 metai baigti turint bendrą 1438,4 tūkst. Lt kreditorini ịsiskolinimą už komunalines ir kitas paslaugas, prekes bei išlaidas. 


\section{Viešieji pirkimai}

VGTU yra perkančioji organizacija, kuri visus pirkimus vykdo vadovaudamasi Lietuvos Respublikos viešuju pirkimu istatymo (toliau - Istatymas) nuostatomis. Šias funkcijas universitete vykdo Viešuju pirkimu skyrius. Viešuju pirkimu skyrius 2014 m. ivykdẻ 79 viešuju pirkimų konkursus, iš jų 19 tarptautinių atviru konkursų, 5 pirkimai ịvykdyti neskelbiamų derybų būdu, 32 supaprastintus atvirus konkursus, 8 pirkimai vykdyti supaprastintos apklausos būdu ir 15 konkursu VGTU supaprastintų mažos vertės pirkimų tvarka (6.15 pav.).

2014 m. bendras ivykdytų viešujų pirkimų konkursų skaičius. lyginant su 2013 m., sumažèjo 28,83 \%. Tam itakos turejjo tai, kad 2014 m. tos pačios paskirties prekių, paslaugu ir darbu pirkimai, skelbiant viešojo pirkimo konkursus, buvo grupuojami, kurie buvo didesnès apimties, skaidomi ị keletą ir daugiau konkurso dalių, bei kurie pareikalavo didesnių viešuju pirkimų specialistų darbo sąnaudų. Bendram $2014 \mathrm{~m}$. ịvykdytų viešujų pirkimų skaičiaus sumažejimui taip pat ịtakos turèjo tai, jog, lyginant su 2013 m., net 50 \% sumažèjo pirkimų, finansuojamų iš Europos Sajungos struktūrinių fondų lèšu. Taip pat tam ịtakos turèjo nuo 2014 m. sausio 1 d. pasikeitęs istatymas, kurio nuostatos ipareigoja perkančiąsias organizacijas ịsigyti prekes, paslaugas ir darbus iš Centrinès perkančiosios organizacijos (toliau - CPO) arba per ją, jeigu tokios prekès, paslaugos ar darbai yra CPO kataloge. 2014 m. 28 pirkimai buvo ivvkdyti per Centrinę perkančiają organizaciją. Ju 2014 m., lyginant su 2013 m., padaugèjo dvigubai. 2014 m. per CPO buvo perkami projektoriai, mobilieji telefonai, kompiuterinè iranga ir jos dalys, kanceliarinès prekès, popierius, vykdyta kilimèlių nuoma, pirktos projektų ekspertizės paslaugos bei projektavimo ir valymo paslaugos.

Viešuju pirkimų skyrius tarptautinio atviro konkurso būdu vykdė kompiuterinès įrangos ir jos dalių, kopijavimo aparatų nuomos, programinės ịrangos, laboratorinės įrangos, baldų Transporto ir civilinės inžinerijos mokslo ir studiju korpusui bei kitiems VGTU padaliniams, elektros energijos, valymo paslaugu pirkimo konkursus.

Viešujų pirkimų skyriaus specialistai ịvkde 32 supaprastintus atvirus konkursus. Kaip ir kiekvienais metais buvo perkamos transporto priemonès, viešinimo, draudimo, judriojo ryšio, léktuvų variklių kapitalinio remonto paslaugos, statybos ir patalpu remonto darbai, kitos prekès ir paslaugos. $2014 \mathrm{~m}$. taip pat buvo perkami VGTU bendrabučiu Nr. 3 (Saulètekio al. 16, Vilnius), Nr. 4 (Saulètekio al. 18, Vilnius) ir Nr. 6 (Saulètekio al. 39A, Vilnius) atnaujinimo (modernizavimo) darbai. Vadovaujantis ịstatymo 84 str. 2 d., kai ịstatymo 2 priedėlyje nurodytu B paslaugu pirkimai vykdomi neatsižvelgiant i pirkimo vertės ribas, buvo perkamos kelionių organizavimo, VGTU bendrabučių administravimo paslaugos.

2014 m., lyginant su 2013 m., padidèjo neskelbiamų derybų būdu vykdytų pirkimų skaičius. Tam ịtakos turèjo tai, kad 2014 m. neivykusiais buvo paskelbti penki atviri konkursai. Atsižvelgiant i tai ir vadovaujantis Lietuvos Respublikos viešujų pirkimu istatymo nuostatomis, visi penki neịvykę konkursai buvo vykdomi neskelbiamų derybų būdu.

Prenumeruojami leidiniai VGTU padaliniams buvo i̇sigyti supaprastintos apklausos būdu. Penkiolika pirkimų buvo vykdomi VGTU supaprastintų mažos vertės pirkimų tvarka.

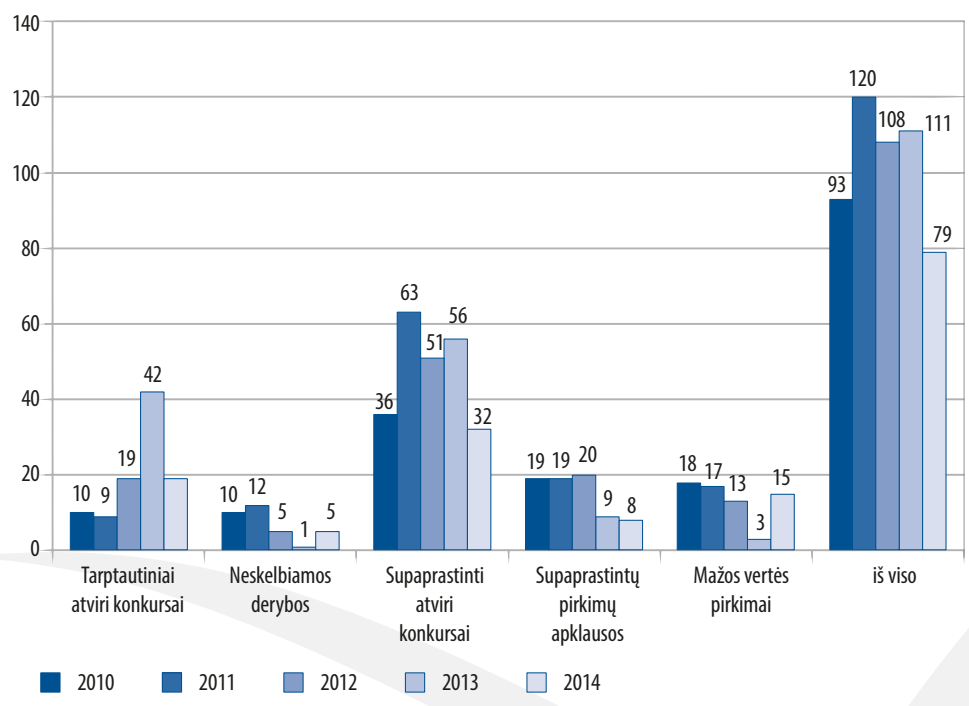

6.15 pav. 2010-2014 m. ivvykdytų viešujų pirkimų konkursų dinamika 


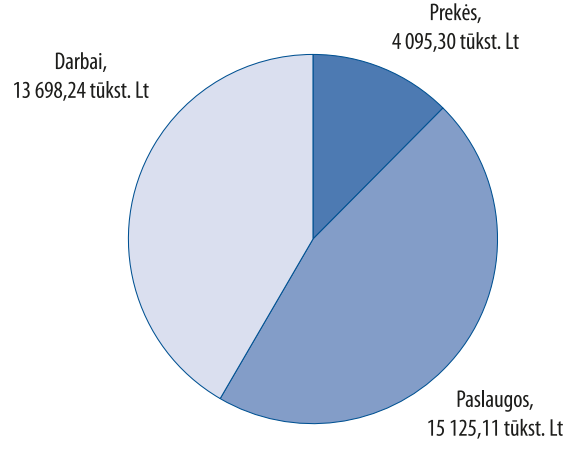

6.16 pav. 2014 m. ivykdytų viešuju pirkimu konkursų verčių sudètis

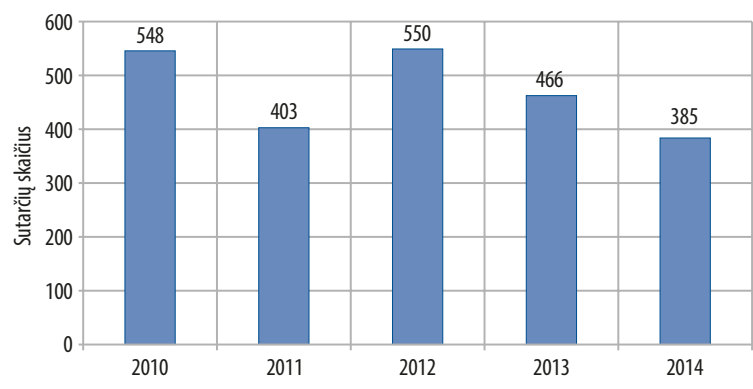

6.17 pav. 2010-2014 m. sudarytu viešojo pirkimo-pardavimo sutarčių skaičius

Ivykdyti 23 viešuju pirkimų konkursai, kurie buvo skirti Europos Sajungos struktūrinių fondų finansuojamiems projektams igyvendinti. Pagal šiuos projektus įsigyta laboratorinè, kompiuterinè ir programinè įranga VGTU padaliniams, konferencijų, seminarų ir mokymų organizavimo, sociologinès kūrèju apklausos atlikimo, programavimo paslaugos, Elektronikos, Mechanikos, Transporto inžinerijos fakultetų laboratorijų korpuso bei Elektronikos, Mechanikos ir Transporto inžinerijos fakultetų mokomujų korpusų techninių projektų parengimo ir projektų vykdymo priežiūros paslaugos, VGTU Antano Gustaičio aviacijos instituto treniruoklių ir laboratoriju korpuso statybos darbai, Produktų dizaino, inovacijų ir kūrybinių industrijų centro „LINK MENŲ fabrikas“ kapitalinio remonto darbai.

Viešujų pirkimų skyrius 2014 m. ìvykdè prekių, paslaugų ir darbų viešujų pirkimų konkursus, kurių vertè siekè 32 918,65 tūkst. Lt (su PVM), iš jų prekių vertè sudarè 4 095,30 tūkst. Lt, paslaugu - 15 125,11 tūkst. Lt, o darbų - 13 698,24 tūkst. Lt (6.16 pav.). Pažymėtina, kad visų ìvykdytų viešujų pirkimų konkursų bendra vertè gali nedaug padidèti, nes viešojo pirkimo procedūros, paskelbtos $2014 \mathrm{~m}$. pabaigoje, dar vykdomos ir su konkursą laimèjusiais tiekèjais sutartys bus sudaromos tik $2015 \mathrm{~m}$.

2014 m. VGTU sudarè 385 prekių, paslaugų ir darbų viešojo pirkimo-pardavimo sutartis (6.17 pav.), kurioms taikomas Lietuvos Respublikos viešujų pirkimų ịstatymas, iskaitant supaprastintus mažos vertès pirkimus.

\subsection{Universiteto infrastruktūra}

\section{Infrastruktūros eksploatavimas ir plètra}

Vienas iš VGTU 2014-2016 m. strateginio veiklos plano uždavinių - sudaryti studijoms ir moksliniams tyrimams tinkamas saugias sąlygas ir užtikrinti efektyvų universiteto valdymą. Šiam uždaviniui igyvendinti 2014 m. buvo vykdoma viena iš priemonių - atnaujinti ir plèsti VGTU mokslo ir studijų infrastruktūrą.

VGTU patikejjimo teise valdo 159 mokslo ir studiju paskirties pastatus, kurių bendras plotas yra 136385,32 m²$^{2}$, iš jų 50 - kitos paskirties infrastruktūros pastatai. 2369,14 m² bendrojo ploto pastatu yra perduota pagal panaudos sutartis Všl VGTU kokybės vadybos centras ir asociacijai Vilniaus Dariaus ir Girèno aeroklubui.

Universiteto bendrujų plotų struktūra pavaizduota 6.18 pav.

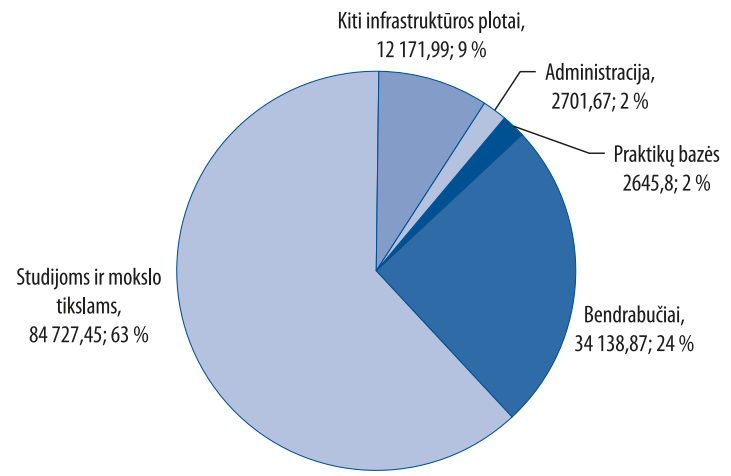

6.18 pav. VGTU valdomų pastatų bendrujų plotų struktūra, $\mathrm{m}^{2} ; \%$ 
Studiju ir mokslo tikslams naudojami plotai sudaro $63 \%$ visų VGTU valdomų plotų. Fakultetams ir mokslo padaliniams priskirti plotai ir struktūra pateikti 6.7 lenteleje, vienam studentui tenkantys plotai pagal fakultetus pateikti 6.8 lenteleje. Vienam studentui tenka 12,69 $\mathrm{m}^{2}$ bendro VGTU turimų pastatu ploto. $2014 \mathrm{~m}$. nedaug sumažejjus studentų skaičiui universitete, vienam studentui tenkantis plotas šiek tiek padidejjo, lyginant su 2013 m. Atlikto aukštujų mokyklų realiujų išteklių vertinimo metu buvo taikyta bendrojo patalpu ploto, tenkančio vienam studentui, rodiklio minimali norma - 10,7 $\mathrm{m}^{2}$ studentui. Taigi šis realiujų ištekliu rodiklis yra tenkinamas.

Nuo 2013 m. visi universiteto pastatai ir statiniai yra apdrausti KASKO draudimu nuo pagrindinių draudimo jvykių, ugnies, vandens, trečiuju asmenų veikų ir pan.

Optimizuojant nekilnojamaji turtą, $2014 \mathrm{~m}$. spalio 14 d. nutarimu Nr. 4-4 VGTU Taryba pakeitė savo 2013 m. lapkričio 26 d. nutarimą Nr. 5-2 - patikslino investuojamo i VGTU dalininko kapitalą turto sąrašą. Sąraše liko Mechanikos (J. Basanavičiaus g. 28), Elektronikos (Naugarduko g. 41) rūmai, patalpos, esančios Bistryčios g. 9, Vilniuje, ir Jauruose I, Molètų rajone, bei kiti smulkūs objektai, netinkami studiju procesui. Pateiktas prašymas LR švietimo ir mokslo ministerijai dèl turto investavimo. Atlikta turto vertinimo procedūra, nustatyta investuojamų pastatų ir statinių rinkos vertè.

6.7 lentelè. VGTU fakultetams ir padaliniams skirti plotai $2014 \mathrm{~m}$.

\begin{tabular}{|c|c|c|c|c|c|c|c|c|c|}
\hline \multirow[b]{2}{*}{$\begin{array}{l}\text { Eil. } \\
\text { Nr. }\end{array}$} & \multirow[b]{2}{*}{ Fakultetas } & \multicolumn{7}{|c|}{ Patalpų plotas, $\mathrm{m}^{2}$} & \multirow{2}{*}{$\begin{array}{l}\text { Bendrojo } \\
\text { naudoji- } \\
\text { mo plotas, } \\
\text { m }^{2}\end{array}$} \\
\hline & & auditorijų & $\begin{array}{c}\text { kompiu- } \\
\text { terinių } \\
\text { klasių }\end{array}$ & $\begin{array}{l}\text { labora- } \\
\text { torijų }\end{array}$ & $\begin{array}{l}\text { moksli- } \\
\text { nių labo- } \\
\text { ratorijų }\end{array}$ & kabinetų & $\begin{array}{l}\text { pagalbi- } \\
\text { nių } \\
\text { patalpų }\end{array}$ & $\begin{array}{c}\text { bendrojo } \\
\text { naudojimo } \\
\text { patalpų }\end{array}$ & \\
\hline 1. & Aplinkos inžinerijos fakultetas & 1816,33 & 131,20 & 750,07 & 86,96 & 1622,62 & 1679,44 & 2794,19 & 8880,81 \\
\hline 2. & Architektūros fakultetas & 1422,52 & 0,00 & 142,32 & 83,30 & 1043,36 & 598,81 & 2124,50 & 5414,81 \\
\hline 3. & Elektronikos fakultetas & 955,34 & 154,50 & 1301,44 & 77,20 & 1033,80 & 2139,60 & 1450,12 & 7112,00 \\
\hline 4. & Fundamentinių mokslų fakultetas & 845,60 & 643,03 & 1344,08 & 229,48 & 1338,21 & 1171,26 & 1410,73 & 6982,39 \\
\hline 5. & Kūrybinių industrijų fakultetas & 500,72 & 0,00 & 0,00 & 0,00 & 3736,34 & 1503,40 & 523,54 & 6264,00 \\
\hline 6. & Mechanikos fakultetas & 1389,29 & 62,91 & 1729,24 & 156,26 & 699,91 & 1077,39 & 774,10 & 5889,10 \\
\hline 7. & Statybos fakultetas & 1676,07 & 149,40 & 1368,66 & 332,46 & 2026,61 & 1568,60 & 2992,55 & 10114,35 \\
\hline 8. & Transporto inžinerijos fakultetas & 1561,54 & 41,32 & 1350,38 & 91,43 & 926,80 & 2276,99 & 1118,76 & 7367,22 \\
\hline 9. & Verslo vadybos fakultetas & 1457,84 & 151,62 & 0,00 & 9,35 & 637,83 & 347,06 & 1738,71 & 4342,41 \\
\hline 10. & $\begin{array}{l}\text { Antano Gustaičio aviacijos } \\
\text { institutas }\end{array}$ & 247,97 & 89,21 & 1659,48 & 0,00 & 1100,27 & 1720,72 & 1098,47 & 5916,12 \\
\hline 11. & Tarptautinių studijų centras & 253,28 & 0,00 & 0,00 & 0,00 & 57,35 & 3,67 & 153,42 & 467,72 \\
\hline 12. & Biblioteka & 991,72 & 0,00 & 0,00 & 0,00 & 647,46 & 906,40 & 691,72 & 3237,30 \\
\hline 13. & $\begin{array}{l}\text { Informacinių technologijų ir } \\
\text { sistemų centras }\end{array}$ & 0,00 & 113,19 & 0,00 & 18,40 & 413,41 & 133,63 & 125,56 & 804,19 \\
\hline 14. & $\begin{array}{l}\text { Termoizoliacijos mokslo } \\
\text { institutas }\end{array}$ & 0,00 & 0,00 & 0,00 & 3066,15 & 718,85 & 4553,64 & 1365,52 & 9704,16 \\
\hline 15. & Kiti mokslo ir studijų padaliniai & 185,91 & 0,00 & 102,88 & 1364,01 & 443,58 & 17,88 & 116,61 & 2230,87 \\
\hline & Iš viso & 13304,13 & 1536,38 & 9748,55 & 5515,00 & 16446,40 & 19698,49 & 18478,50 & 84727,45 \\
\hline
\end{tabular}

6.8 lentelè. VGTU fakultetuose vienam studentui tenka patalpu ploto, $\mathrm{m}^{2}$

\begin{tabular}{|c|c|c|c|c|}
\hline $\begin{array}{l}\text { Eil. } \\
\text { Nr. }\end{array}$ & Fakultetas & Priskirtas plotas, $\mathrm{m}^{2}$ & Studentų skaičius 2014 m. & $\begin{array}{c}\text { Vidutiniškai vienam } \\
\text { studentui tenka ploto, } \mathrm{m}^{2}\end{array}$ \\
\hline 1. & Aplinkos inžinerijos & 8880,81 & 1293 & 6,87 \\
\hline 2. & Architektūros & 5414,81 & 559 & 9,69 \\
\hline 3. & Elektronikos & 7112,00 & 968 & 7,35 \\
\hline 4. & Fundamentinių mokslų & 6982,39 & 1279 & 5,46 \\
\hline 5. & Kūrybinių industrijų & 6264,00 & 585 & 10,71 \\
\hline 6. & Mechanikos & 5889,10 & 923 & 6,38 \\
\hline 7. & Statybos & 10114,40 & 1489 & 6,79 \\
\hline 8. & Transporto inžinerijos & 7367,22 & 1599 & 4,61 \\
\hline 9. & Verslo vadybos & 4342,41 & 1514 & 2,87 \\
\hline 10. & Tarptautinių studijų centras & 467,72 & - & - \\
\hline 11. & Antano Gustaičio aviacijos institutas & 5916,12 & 354 & 16,71 \\
\hline 12. & Bendrieji ir kiti infrastruktūros plotai & 65257,00 & 10917 & 5,98 \\
\hline & Iš viso & 134007,98 & 10563 & 12,69 \\
\hline
\end{tabular}


2014 m. baigtos žemès sklypo (Rodūnios kelias 30, 32) formavimo procedūros, pasirašytas susitarimas dèl sklypo naudojimosi tvarkos nustatymo su kitais sklypo bendraturčiais. Baigiami sklypo panaudos sutarties pasirašymo formalumai.

VGTU iggvendina iš ES struktūrinių fondų lèšų finansuojamą projektą „Aviacijos specialistų rengimo mokomosios bazės plètra: Treniruoklių ir laboratorijų korpuso statyba“. Igyvendinant ši projektą, minètą korpusą nuspręsta įrengti gamybinės paskirties pastate, esančiame Linkmenu g. 28, atliekant pastato rekonstrukciją ir ji praplečiant.

2014 m. rugsèjo 24 d. Lietuvos Respublikos Vyriausybei prièmus nutarimą Nr. 1003 „Dėl nekilnojamuju daiktų Vilniuje, Linkmenu g. 28, nurašymo“ ir gavus visus reikalingus leidimus buvo nugriauti trys pripažinti netinkamais (negalimais) naudoti pastatai Linkmenu g. 28 (pastatų bendras plotas 3308,70 m²), trukdę naujo Antano Gustaičio aviacijos instituto Treniruoklių ir laboratorijų korpuso statybai.

Lietuvos Respublikos Vyriausybės 2014 m. gruodžio 23 d. nutarimu Nr. 1453 „Dèl LR Vyriausybės 2007 m. spalio 10 d. nutarimo Nr. 1082 „Dèl atnaujinamo valstybès nekilnojamojo turto sąrašo patvirtinimo“ pakeitimo“" pakeistas atnaujinamo valstybės turto sąrašas ir sudarytos sąlygos VGTU AGAI Treniruoklių ir laboratorijų korpuso statybos darbams kofinansuoti.

Vilniaus Gedimino technikos universitetas, siekdamas prisidèti prie darnios visuomenès plètros, modernizuodamas ir plètodamas turimos bei planuojamos infrastruktūros valdymą, ypatingą dèmesi skiria atsakingam ir racionaliam gamtinių išteklių naudojimui, darnios plètros nuostatų integravimui i studijas ir mokslinius tyrimus. Šiems principams igyvendinti 2014 m. sukurta ir 2015 m. sausio 20 d. Senato posèdyje patvirtinta žaliojo universiteto koncepcija.

Koncepciją sudaro šios pagrindinès veiklos kryptys (dalys):

1. Efektyvus energinių išteklių vartojimas.

2. Efektyvus atlieku tvarkymas.

3. Žaliujų pirkimų organizavimas.

4. Moksliniai tyrimai, mokslinių tyrimų rezultatų sklaida (konferencijos seminarai, parodos ir pan.).

5. Studijos, integruojančios darnios plètros idejjas.

6. Socialiai atsakinga veikla ir ịvaizdžio formavimas.

Kiekvienai koncepcijos veiklos krypčiai igyvendinti numatytos konkrečios priemonès.

Kasmet tobulinamas VGTU energinio ūkio valdymas. Universiteto balanse yra 20 šilumos punktų, kurie šildo apie 99,2 tūkst. kv. m plotą. Šilumos ūkio valdymą ir priežiūrą atlieka šeši VGTU Energetikos skyriaus darbuotojai, kurie atlieka šilumos punktų techninę priežiūrą, paruošimą šildymo sezonui, darbo kontrolę. Išlaidos už šilumos energiją sudaro 36 \% visų metinių eksploatacinių išlaidų, todèl vienas iš Energetikos skyriaus prioritetų yra VGTU energinių išteklių taupymo 2014-2016 m. priemonių plano ir žaliojo universiteto koncepcijos igyvendinimas. 2014 m. trijuose šilumos punktuose buvo i̇diegta šiuolaikinè šilumos reguliavimo įranga, kuri leidžia pasirinkti optimalų, ekonomišką šilumos punktų režimą ir stebèti bei keisti parametrus nuotoliniu būdu bet kuriuo paros metu. Iš 20 šilumos punktų modernizuotos aštuonios šilumos punktų valdymo sistemos. Per artimiausius dvejus metus šias sistemas planuojama idiegti likusiuose šilumos punktuose. Automatizuotas šilumos punktų valdymas leidžia taupyti šilumos energiją ir šildymo išlaidas. Nuolat stebint ir fiksuojant šildymo sistemų techninius duomenis ir taikant renovuotų šilumos punktų automatikos naujoves, 2014 m. pavyko sumažinti suvartojamos šilumos kiekị 496 MWh (8,0 \% nuo 2013 m. suvartotos šilumos energijos kiekio). Dèl to sumažèjo ir visos metinès eksploatacinès išlaidos. VGTU pastatų eksploatacinių išlaidų kaita 2010-2014 m. pavaizduota 6.19 pav. VGTU pastatų eksploatacinès išlaidos yra vienos iš mažiausių tarp Lietuvos universitetų.
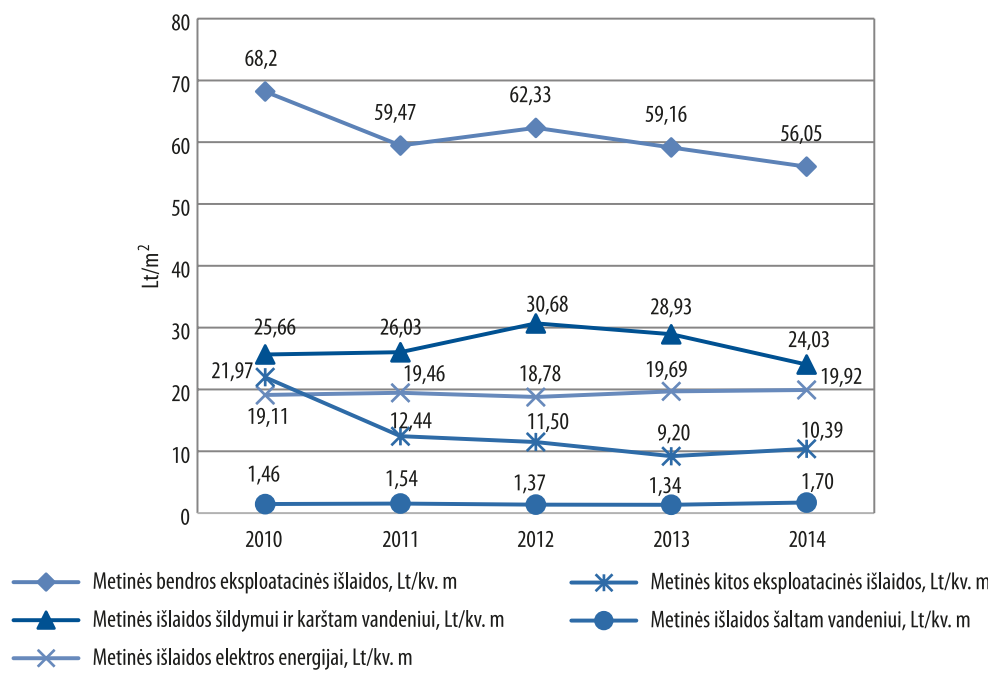

6.19 pav. VGTU pastatų eksploatacinių išlaidų kaita 2010-2014 m. 
Taupant šilumos energiją beveik visuose VGTU mokomuosiuose pastatuose karštas vanduo ruošiamas ne centralizuotu būdu, o vietiniais elektriniais vandens šildytuvais. Centralizuotai karštas vanduo ruošiamas tik bibliotekoje (Saulėtekio al. 14), kurioje irengtas bendras bibliotekos ir bendrabučiu Nr. 3 ir Nr. 4 šilumos punktas, ruošiantis karštą vandeni bendrabučių gyventojams ir Sporto salèje (Saulètekio al. 28), kurioje naudojamos dušinès, todèl šių pastatų šilumos energijos sąnaudos yra didesnès. Šilumos sąnaudoms sumažinti parengtas projektas rekonstruoti šilumos punktą bibliotekoje, naujai įrengiant atskirus šilumos punktus bendrabučiuose Nr. 3 ir Nr. 4.

$2014 \mathrm{~m}$. buvo modernizuota Elektronikos fakulteto šilumos punkto valdymo sistema. Ji leidžia optimaliai parinkti šildymo sistemos darbo režimą. Todèl naudojamas racionalus dujų kiekis, užtikrinantis Elektronikos fakulteto šildymą. Elektronikos fakulteto šilumos punkto reguliavimo parametrus galima keisti nuotoliniu būdu bet kuriuo paros metu.

Elektros energiją universitetas ketvirtus metus pirko konkurso būdu iš nepriklausomų elektros energijos tiekèjų fiksuotomis kainomis, kurios nepriklauso nuo kainų svyravimų rinkoje ir leidžia taupyti lèšas. Šią energiją savo skirstomaisiais tinklais universitetui pateikia AB „Lesto“ i 21-ą elektros skirstymo skydinę. Elektros ūkyje dirba dešimt Ūkio direkcijos Energetikos skyriaus darbuotojų, kurie prižiūri elektros energijos tiekimą universiteto padaliniams, atlieka elektros instaliacijos ir apšvietimo remonto, montavimo ir profilaktikos darbus, tvarko dokumentus. Daugiau kaip pusė elektros energijos skaitiklių nuskaitomi nuotoliniu būdu, kiti duomenys surenkami ir deklaruojami i AB „Lesto“ portalą, o informacija apie mokètinas sumas gaunama prisijungus prie $A B$,Lesto“ internetinio portalo.

2014 m., siekiant sumažinti nuostolius, atsirandančius gendant elektroninei įrangai dèl atmosferinių elektros iškrovų, buvo sumontuotos apsaugos nuo viršitampių Saulètekio rūmų centriniame budètojų poste. Per dvejus metus planuojama šias priemones idiegti visuose pastatuose jautriai elektroninei ịrangai apsaugoti. Energijai taupyti pradèti naudoti šviesos diodu (LED) šviestuvai, ieškant efektyviausio technologinio sprendimo, sumontuota kelių paskirčių ir konstrukcijų šios rūšies šviestuvų. Modernizuotas Mechanikos rūmų kiemo apšvietimas moderniais LED šviestuvais. Bendros universiteto išlaidos elektros energijai $2014 \mathrm{~m}$. padidejjo 18 tūkst. Lt ir sudarè 1695 tūkst. Lt (1,06 \% nuo 2013 m. turètų išlaidų). Iš viso 2014 m. buvo suvartota 5052 tūkst. kWh elektros energijos, t. y. 68 tūkst. kWh, arba 1,33 \% mažiau negu 2013 m. VGTU pastatų eksploatacinių išlaidụ duomenys 2014 metams pateikti 6.20 pav. ir 6.9 lentelèje.

lgyvendinant vieną iš VGTU 2014-2016 m. strateginio veiklos plano uždavinių - sudaryti studijoms ir moksliniams tyrimams tinkamas saugias sąlygas ir užtikrinti efektyvų universiteto valdymą, 2014 m. atlikta projektavimo, statybos, rekonstravimo, atnaujinimo ir remonto darbų už 19,8 mln. Lt (6.21 pav.), iš jų rangos būdu - už 19,1 mln. Lt. Universiteto pastatų patalpu $1 \mathrm{~m}^{2}$ atnaujinti vidutiniškai teko 145 Lt. Palyginus su 2013 m., darbu apimtis padidèjo 3,3 karto. Finansavimo šaltiniai ir jų dinamika 2010-2014 m. pateikti 6.10 lentelejje.

$2014 \mathrm{~m}$. rangos būdu rekonstruota ir suremontuota (6.11 lentelè) 930,55 $\mathrm{m}^{2}$ auditoriju, $372,93 \mathrm{~m}^{2}$ bendrojo naudojimo patalpu (iš to skaičiaus $193,0 \mathrm{~m}^{2}$ bendrabučių patalpų), nugriauta $3308,7 \mathrm{~m}^{2}$ pastatų. Bendras rangos būdu rekonstruotų ir suremontuotų patalpu plotas sudaro 1303,48 m². Ūkio būdu suremontuota 3236,0 $\mathrm{m}^{2}$ patalpu ploto. Bendras rekonstruotų ir suremontuotu patalpu plotas sudaro 3,4\% nuo bendro valdomo patalpų ploto. Patalpoms atnaujinti skirtų léšų santykis su VGTU bendromis biudžeto iplaukomis - 14,3\%.

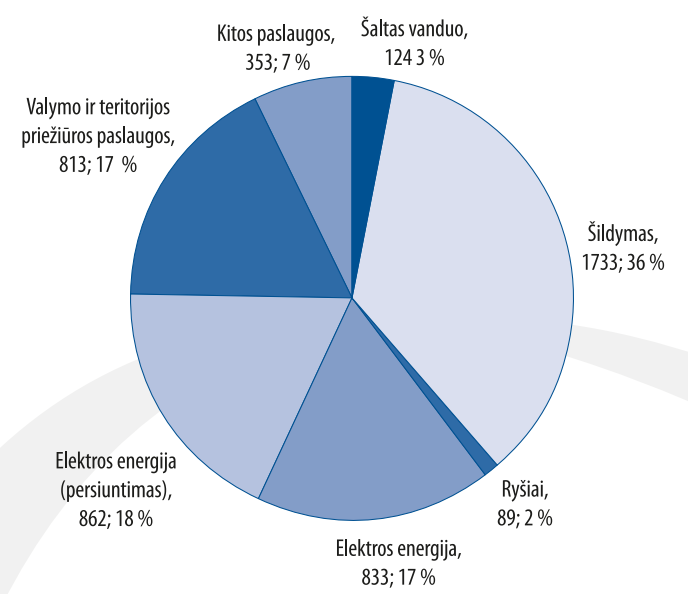

6.20 pav. VGTU pastatų eksploatacinių išlaidų struktūra 2014 m., tūkst. Lt; \%

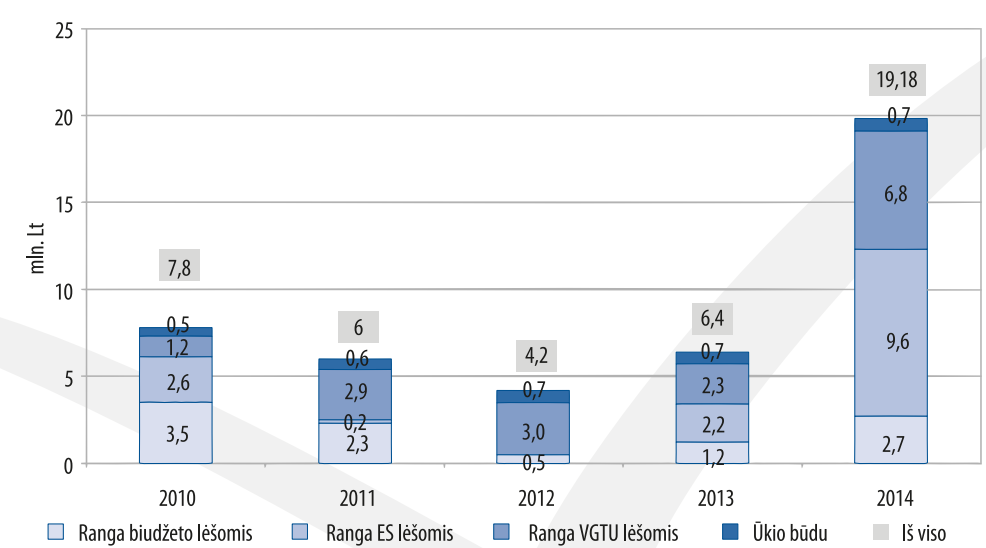

6.21 pav. Statybos, rekonstravimo ir remonto darbų apimtis 2010-2014 m., mln. Lt 
6.9 lentelè. VGTU pastatu eksploatacinès išlaidos $2014 \mathrm{~m}$.

\begin{tabular}{|c|c|c|c|c|c|c|c|c|c|c|c|c|c|}
\hline \multirow[b]{2}{*}{$\begin{array}{l}\dot{\bar{z}} \\
\dot{\overline{\dot{u}}}\end{array}$} & \multirow[b]{2}{*}{$\begin{array}{l}\text { Rūmai, } \\
\text { adresas }\end{array}$} & \multirow[b]{2}{*}{ 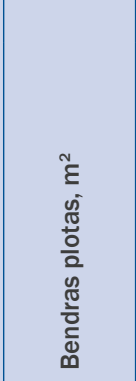 } & \multirow[b]{2}{*}{$\begin{array}{l}\text { है } \\
\text { ज } \\
\frac{\pi}{0} \\
\frac{0}{2} \\
\text { in } \\
\frac{\Xi}{0} \\
\frac{0}{0} \\
\text { in }\end{array}$} & \multirow[b]{2}{*}{ 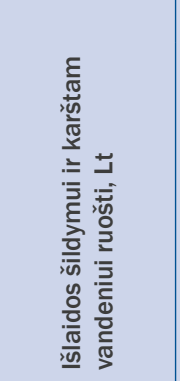 } & \multirow[b]{2}{*}{ 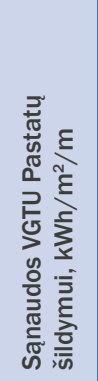 } & \multirow[b]{2}{*}{ 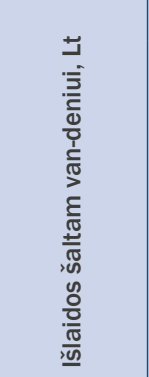 } & \multirow[b]{2}{*}{ 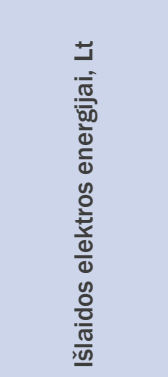 } & \multirow[b]{2}{*}{ 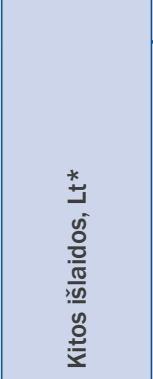 } & \multicolumn{5}{|c|}{ Metinès išlaidos } \\
\hline & & & & & & & & & 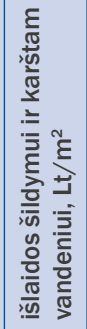 & 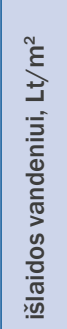 & 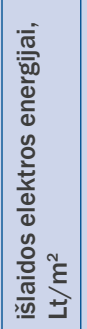 & 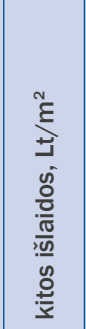 & 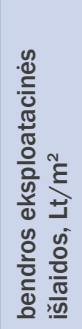 \\
\hline 1. & $\begin{array}{l}\text { Saulètekio rūmai. } \\
\text { Saulètekio al. } 11\end{array}$ & 35945,49 & 35257,33 & 802277,87 & 80,09 & 60240,73 & 815489,70 & 480521,69 & 22,75 & 1,68 & 22,69 & 13,37 & 60,49 \\
\hline 2. & $\begin{array}{l}\text { Biblioteka, } \\
\text { Saulètekio al. } 14\end{array}$ & 2587,31 & 2587,31 & 26391,85 & 35,98 & 4724,94 & 77289,98 & 6806,24 & 10,20 & 1,83 & 29,87 & 2,63 & 44,53 \\
\hline 3. & $\begin{array}{l}\text { Mechanikos } \\
\text { rūmai, J. Basa- } \\
\text { navičiaus g. } 28\end{array}$ & 7435,00 & 7175,04 & 193719,47 & 95,00 & 13413,16 & 141993,66 & 98482,74 & 27,00 & 1,80 & 19,10 & 13,25 & 61,15 \\
\hline 4. & $\begin{array}{l}\text { Architektūros } \\
\text { rūmai, Trakų g. } 1\end{array}$ & 10169,04 & 9814,61 & 265561,10 & 95,10 & 16464,84 & 117082,71 & 129562,07 & 27,06 & 1,62 & 11,51 & 12,74 & 52,93 \\
\hline 5. & $\begin{array}{l}\text { Aviacijos rūmai, } \\
\text { Rodūnios kelias } \\
30 * *\end{array}$ & 2023,79 & 1416,23 & 40367,37 & 100,18 & 1471,80 & 53743,20 & 5562,02 & 28,50 & 0,73 & 26,56 & 2,75 & 58,53 \\
\hline 6. & $\begin{array}{l}\text { Transporto rūmai. } \\
\text { Plytinės g. } 27\end{array}$ & 5406,07 & 2133,31 & 37732,15 & 62,22 & 9795,66 & 45521,06 & 37249,91 & 17,69 & 1,81 & 8,42 & 6,89 & 34,81 \\
\hline 7. & $\begin{array}{l}\text { Elektronikos } \\
\text { rūmai, Naugar- } \\
\text { duko g. 41** }\end{array}$ & 6195,75 & 4779,48 & 92044,03 & 112,85 & 4166,99 & 91499,33 & 83660,38 & 19,26 & 0,67 & 14,77 & 13,50 & 48,20 \\
\hline 8. & $\begin{array}{l}\text { Sporto salè. } \\
\text { Saulètekio al. } \\
28 * *\end{array}$ & 2139,56 & 2139,56 & 57814,51 & 95,88 & 4710,01 & 27819,85 & 6374,68 & 27,02 & 2,20 & 13,00 & 2,98 & 45,21 \\
\hline 9. & $\begin{array}{l}\text { Linkmenų rūmai. } \\
\text { Linkmenų g. } 28\end{array}$ & 8828,84 & 5104,98 & 186387,88 & 128,47 & 9264,10 & 270271,99 & 24136,75 & 36,51 & 1,05 & 30,61 & 2,73 & 70,91 \\
\hline 10. & $\begin{array}{l}\text { Kyviškiu Skrydžiu } \\
\text { valdymo praktikų } \\
\text { bazė** }\end{array}$ & 1722,55 & 1681,13 & 30320,58 & 136,88 & 53,20 & 32 967,02 & 7575,54 & 18,04 & 0,03 & 19,14 & 4,40 & 41,60 \\
\hline 11. & Iš viso / vidutinès & 82453,40 & 72088,98 & 1732616,81 & 96,30 & 124305,43 & 1673678,50 & 879932,02 & 24,03 & 1,51 & 20,30 & 10,67 & 56,51 \\
\hline 12. & $\begin{array}{l}\text { Kiti infrastruk- } \\
\text { tūros pastatai }\end{array}$ & 2624,31 & 0,00 & 0,00 & 0,00 & 0,00 & 21023,93 & 4319,65 & 0,00 & 0,00 & 8,01 & 1,65 & 9,66 \\
\hline 13. & Iš viso / vidutinès & 85077,71 & 72088,98 & 1732616,81 & 96,30 & 124305,43 & 1694702,43 & 884251,67 & 24,03 & 1,51 & 19,92 & 10,39 & 55,85 \\
\hline
\end{tabular}

6.10 lentelè. Statybos, rekonstravimo ir remonto darbu (rangos būdu) jivykdyta apimtis ir finansavimo šaltiniai 2010-2014 m., tūkst. Lt

\begin{tabular}{|c|c|c|c|c|c|c|}
\hline \multirow{2}{*}{$\begin{array}{l}\text { Eil. } \\
\text { Nr. }\end{array}$} & \multirow{2}{*}{ Finansavimo šaltiniai } & \multicolumn{5}{|c|}{ Metai } \\
\hline & & 2010 & 2011 & 2012 & 2013 & 2014 \\
\hline 1. & Valstybės investicijų programos lèšos & 1500,0 & 838,4 & 276,7 & 1100,0 & 2500,0 \\
\hline 2. & Biudžeto lèšos paprastajam remontui & 157,3 & 1228,8 & 268,9 & 98,2 & 0,0 \\
\hline 3. & VGTU nuosavos lèšos paprastajam remontui & 568,3 & 1654,3 & 1355,4 & 760,2 & 671,5 \\
\hline 4. & $\begin{array}{l}\text { VGTU nuosavos lèšos pastatú statybos, renovavimo, } \\
\text { rekonstravimo, atnaujinimo programoms lgyvendinti } \\
\text { (nuosavas indėlis): }\end{array}$ & & & & & \\
\hline 4.1. & Studentų bendrabučiams atnaujinti & 182,6 & 0,0 & 494,4 & 250,4 & 278,6 \\
\hline 4.2. & Kitiems pastatams ir statiniams & 425,1 & 1270,2 & 1078,4 & 1264,5 & 5813,2 \\
\hline 5. & $\begin{array}{l}\text { Kultūros paveldo objektams prižiūrèti } \\
\text { skirtos lèšos }\end{array}$ & 181,0 & 180,0 & 0,0 & 0,0 & 0,0 \\
\hline 6. & $\begin{array}{l}\text { Aukštujų mokyklų studentų bendrabučių atnaujinimo } \\
\text { programų lěšos }\end{array}$ & 1722,0 & 0,0 & 0,0 & 0,0 & 223,0 \\
\hline \multirow[t]{2}{*}{7.} & Europos Sajungos fondų lèšos & 2593,0 & 181,6 & 0,0 & 2258,6 & 9582,5 \\
\hline & Iš viso & 7329,3 & 5353,3 & 3473,8 & 5731,9 & 19068,8 \\
\hline
\end{tabular}


6.11 lentelè. 2014 m. rangos būdu rekonstruota, suremontuota patalpų ir atskirų konstrukcijų

\begin{tabular}{|c|c|c|c|c|}
\hline Eil. Nr. & Patalpų paskirtis & Mato vnt. & Kiekiai & Rūmai, fakultetai \\
\hline 1. & Auditorijos & $\mathrm{m}^{2}$ & 930,55 & Saulètekio rūmai Centrinis korpusas, Statybos fakultetas \\
\hline \multirow{2}{*}{2.} & \multirow{2}{*}{ Bendrojo naudojimo patalpos } & \multirow{2}{*}{$m^{2}$} & \multirow{2}{*}{372,93} & Architektūros rūmai, Kūrybinių industrijų fakultetas \\
\hline & & & & Saulètekio rūmai, Aplinkos inžinerijos fakultetas \\
\hline 4. & Pastatu griovimas & $\mathrm{m}^{2}$ & 3308,7 & Linkmenu rūmų gamybinis pastatas ir galerijos \\
\hline
\end{tabular}

Didesnioji darbų dalis atlikta Europos Sajungos struktūrinių fondų lèšomis. Buvo tęsiama Mokslo ir administracijos centro Transporto ir civilinès inžinerijos mokslo ir studijų korpuso statyba Saulètekio alèjoje - įrengiamos fasadinės sistemos, stogai, montuojamos inžinerinės sistemos, atliekama apdaila.

Užbaigus rengti technini projektą, pradėtas rekonstruoti Antano Gustaičio aviacijos instituto Treniruoklių ir laboratoriju korpusas Linkmenu g. 28, Vilniuje - išardytos nereikalingos konstrukcijos, irengiamos atitvaros. Taip pat šiame sklype pradėtas igyvendinti projektas „VGTU ir Edinburgo Neipiero universitetų Produktų dizaino, inovacijų ir kūrybinių industrijų centro „LINK MENŲ fabrikas“ sukūrimas“ - kapitališkai padèta remontuoti nebenaudojamo pastato dalis, kurioje isikurs nauji universiteto mokslo ir studiju padaliniai.

Siekiant optimaliai panaudoti mokslo ir studijų infrastruktūrą ir atnaujinti Elektronikos, Mechanikos ir Transporto inžinerijos fakultetų mokomają bei mokslinę bazę, pradèti rengti Elektronikos, Mechanikos ir Transporto inžinerijos fakultetų laboratorijų korpuso, Elektronikos fakulteto mokomojo korpuso bei Mechanikos bei Transporto inžinerijos fakultetų mokomojo korpuso techniniai projektai. Šių techninių projektų parengimas finansuojamas 2007-2013 m. Ekonomikos augimo veiksmų programos 1 prioriteto „Ūkio konkurencingumui ir ekonomikos augimui skirti moksliniai tyrimai ir technologinè plètra“ projekto „VGTU Elektronikos, Mechanikos ir Transporto inžinerijos fakultetų perkèlimas i Saulètekio studentų miesteli (I etapas - dokumentacijos parengimas)“ léšomis.

Vadovaujantis Lietuvos Respublikos švietimo ir mokslo ministro 2012 m. kovo 22 d. issakymu Nr. V-525 patvirtinta Aukštujų mokyklų ir profesinio mokymo istaigų bendrabučių atnaujinimo (modernizavimo) programa, pradèti bendrabučio Nr. 6 atnaujinimo darbai.

Iš viso Europos Sajungos struktūrinių fondų lèšomis atlikta projektavimo paslaugu ir statybos darbu už 9521,4 tūkst. Lt.

Valstybės investicijų programos lèšomis buvo tęsiami tvarkybos darbai Architektūros rūmų rūsyje (419,0 tūkst. Lt) - sumontuotos inžinerinès sistemos, atlikta apdaila; Mokslo ir administracijos centre (II ir III statybos etapai) Saulètekio alèjoje (2 081,0 tūkst. Lt) montuojamos inžinerinès sistemos, irengiamos pastato konstrukcijos. Iš viso Valstybès investiciju programos lėšomis atlikta darbų ir projektavimo paslaugų už 2500,0 tūkst. Lt.

Universiteto nuosavomis léšomis kofinansuoti Mokslo ir administracijos centro I etapo statybos darbai, parengtas Sauletekio al. ir Šatrijos Raganos g. dalies ties VGTU Mokslo ir administracijos centru rekonstravimo techninis projektas, nugriauti netinkami naudoti pastatai Linkmenu g. 28, atliktas Architektūros rūmu 119-os auditorijos ir Saulètekio rūmų centrinio korpuso Verslo vadybos fakulteto patalpu remontas. Taip pat buvo baigti atnaujinimo darbai Saulètekio rūmų II korpuse ir II laboratoriniame korpuse, praplèstos, tobulintos ir remontuotos apsaugos, perèjimo kontrolès, gaisro aptikimo sistemos, bendrabučiuose Nr. 1 ir Nr. 5 modernizuotas kompiuterinis tinklas, parengti bendrabučių Nr. 3, Nr. 4, Nr. 6 atnaujinimo (modernizavimo) techniniai projektai. Iš viso VGTU nuosavomis lěšomis atlikta darbų ir projektavimo paslaugų už 6763,28 tūkst. Lt.

Švietimo ir mokslo ministerijos tikslinėmis lěšomis (223,0 tūkst. Lt) atnaujintas bendrabučio Nr. 6 penkto aukšto koridorius ir gyvenamosios patalpos.

Spręstinos VGTU pastatų infrastruktūros plètros ir eksploatavimo problemos:

1. Dabartiniu metu VGTU studijų ir mokslo pastatai išdėstyti septyniose Vilniaus miesto vietose, tai apsunkina studiju ir mokslinių tyrimu procesu organizavimą bei universiteto administravimą, dèl to turima papildomų išlaidų. Tikslinga sutelkti daugumą fakultetų pagrindiniame VGTU studentu miestelyje - Saulètekio studentu miestelyje. Nepakankamas kai kurių fakultetu patalpu plotas, tenkantis vienam studentui. Šią problemą padètų išspręsti Mokslo ir administracijos centro statybos užbaigimas, Elektronikos, Mechanikos ir Transporto inžinerijos fakultetų laboratorijų korpuso, Elektronikos fakulteto mokomojo korpuso, Mechanikos ir Transporto inžinerijos fakultetų mokomojo korpuso bei AGAI laboratorijų ir treniruoklių korpuso statyba. 
2. Aktuali problema lieka dalies mokomuju ir laboratorijų korpusų, kurie nepateko i ES struktūrinių fondụ finansuojamos priemonès VP3-3.34-ŪM-03-V „Viešosios paskirties pastatų renovavimas nacionaliniu lygiu“ valstybės projektų sąrašą, atnaujinimas (modernizavimas). 2015 m. planuojama parengti šių pastatų techninius projektus ir teikti paraišką i Lietuvos aplinkos apsaugos investicijų fondui dèl visuomeninès paskirties pastatų atnaujinimo gerinant energines charakteristikas pagal klimato kaitos specialiają programą.

3. Svarbu didinti VGTU valdomo turto naudojimo efektyvumą, atsisakyti universitetui pagrindinei veiklai nereikalingų pastatų ir patalpų. Lèšas, gautas teisès aktų nustatyta tvarka pardavus pastatus, panaudoti VGTU infrastruktūros plètrai kofinansuoti.

4. Kaip ir praejjusiais metais, statybas užbaigti laiku trukdė klaidos, netikslumai projektuose, problemos, kylančios užsitęsus objektų statybos laikotarpiams dèl nepakankamo finansavimo.

\section{Biblioteka}

Biblioteka savo veiklos turiniu ir rezultatais skatina mokslo bei studiju pažangą, ugdo informacinę bendruomenès veiklą. Teikiamų paslaugų kokybė buvo nuolat tobulinama siekiant, kad jos atitiktų informacinius skaitytoju poreikius. Biblioteka - aktyvi Lietuvos akademinių bibliotekų ateities kūrimo dalyvè. Ji dalyvauja keliuose valstybinès reikšmės projektuose: Lietuvos mokslinių biblioteku asociacijos (toliau - LMBA) vykdomame Europos socialinio fondo finansuojamame „eMoDB.LT: Elektroninių mokslo duomenų bazių atvèrimas Lietuvai“ (toliau eMoDB.LT2), „eLABa integralių paslaugų sukūrimas ir plètra“, Europos socialinio fondo agentūros igyvendiname projekte "Studijų prieinamumo užtikrinimas specialiuju poreikių turintiems studentams“. Ji yra Lietuvos akademinių bibliotekų informacinès infrastruktūros mokslui ir studijoms palaikymo ir plètros konsorciumo (toliau - LABIIMSPP konsorciumas) narè.

2014 m. bibliotekos prioritetinès veiklos kryptys buvo akademinės bendruomenės informacinių poreikiu analizè, teikiamų paslaugu viešinimas, mokymų organizavimas ir vartotojų informacijos paieškos gebėjimų ugdymas. Vyko susitikimai, teikiamų paslaugu pristatymai akademinei - Aplinkos inžinerijos, Verslo vadybos, Elektronikos, Kūrybinių industrijų ir Architektūros fakultetų - bendruomenei, analizuoti fakultetų informaciniai poreikiai.

Universiteto vardu skelbtu publikacijų registravimas, apskaita ir bibliometriniu analizių vykdymas - viena iš pagrindinių veiklos sričių. Nuo 2014 metu publikacijų ịrašuose pradèta pildyti informacija, nurodanti prioritetines moksliniu tyrimų kryptis ir tematikas bei sumanias Lietuvos specializacijas. Kartu su Mokslo direkcija parengtas mokslinių tyrimų krypčių klasifikatorius, kuriuo papildyta publikacijų registravimo el. forma ir PDB klasifikatoriai. Parengta publikaciju ikèlimo i institucinę talpyklą tvarka.

Ypatingas dèmesys skiriamas bibliotekos teikiamų paslaugų gerinimui ir pritaikymui vartotojo poreikiams:

- patobulinta knygu užsakymo el. formos administracinė aplinka - idiegtas grižtamasis ryšys su užsakovais;

- atsižvelgiant i Architektūros fakulteto bendruomenès ir studentų poreikius iki 21:00 val. prailgintas skaityklos darbo laikas. Skaitykloje suformuotas jau antras bibliotekoje individualus darbo kambarys 3-4 žmoniu grupei. Sukurta Darbo kambario elektroninė rezervavimo forma;

- visuose fakultetu skaityklose įdiegta knygu išdavimo i namus paslauga;

- siekiant prisitaikyti prie kintančių vartotojų poreikių, padedant ITSC, iddiegta savitarnos spausdinimo, kopijavimo ir skenavimo paslauga, kuria lankytojai gali naudotis visą parą;

- kompiuterizuotos darbo vietos specialiuju poreikiu turintiems studentams papildytos nauja įranga - keturiais vaizdo didintuvais ir Brailio rašto spausdintuvu.

Prisidedama prie skaitmeninio turinio didinimo:

- tęsiamas „Inžinerinės minties“ projektas. Skaitmeninami XIX a. pab. - XX a. pr. išleisti technikos mokslų leidiniai. Nuskenuotas 4771 puslapis (21 knyga);

- bendradarbiaujant su leidykla „Technika“ i VGTU institucinę talpyklą DSpace įkelta 30 VGTU vardu paskelbtų viso teksto publikaciju.

Pagal Erasmus akademinio ir kito personalo mobilumo programą trys darbuotojai lankèsi trijose užsienio šalyse - Turku taikomujų mokslų universitete (Suomija); Kopenhagos Metropolitan University College (Danija) bei Liuleo (Lulea) technologijos universitete (Švedija). Dalyvavome 11-ajame Latvijos bibliotekininkų kongrese. Šešios bibliotekos darbuotojos dvylika kartų kèlè kvalifikaciją ivairiuose seminaruose ir mokymuose Lietuvoje. Vykdème projektą „Išmanus, išmanesnis, išmaniausias...“, kurio metu bibliotekos darbuotojai tobulino profesines žinias.

Esame Lietuvos kolegijų bibliotekų praktinè bazè. 2014 m. mūsų bibliotekoje mokèsi Lietuvos kolegijų bibliotekų darbuotojai. Ataskaitiniais metais biblioteką aplankè kolega iš Baltarusijos nacionalinio technikos universiteto bibliotekos. Pagal Erasmus programą stažavosi kolegė iš Malagos universiteto (Ispanija). 
Bibliotekos erdvėse vyko „ESTIEM“ (European Students of Industrial Engineering and Management) mokymai studentams, Korèjiečių vakaras, Užsienio ryšių direkcijos organizuojamos Tarptautinès administracijos darbuotoju savaitės „3xC Mobility - Challenges, Changes, Communitcation“ renginiai.

Informacijos ištekliai. 2014 m. leidiniams ịsigyti išleista per 500 tūkst. Lt (6.12 lentelè).

Universiteto bendruomenè knygas užsakè naudodamasi el. leidinių užsakymo forma, kuri per metus atversta 1344 kartus. Gauti 448 užsakymai, pasiūlyta issigyti 1129 pav. knygu, iš jų 29 užsakymai gauti iš „BUSBiblioteka-universitetas-studentas“ (toliau - BUS) el. paslaugos (6.22 pav.).

2014 m. universiteto bendruomenè turèjo prieigą prie 31 duomenų bazės (toliau - DB). El. išteklių skaičius pavadinimais beveik tris kartus viršijo bibliotekoje turimų tradicinių leidinių pavadinimu skaičiu (6.12 lentelè). 2014 m. prieinamų el. išteklių skaičius padidejjo 18448 viso teksto dokumentais (6.23 pav.).

Per metus bendruomenè taip pat galèjo naudotis informacijos ištekliais, esančiais 22-iose terminuotos prieigos DB. Iš viso už ivairių DB prenumeratą sumokèta apie 100 tūkst. Lt.

Aleph bibliotekinès programos aplinkoje pildomas el. katalogas ir kuriamos keturios lokalios DB. Ataskaitiniais metais ji sudarè 208807 bibliografiniai įrašai. Per metus buvo ivesta 17744 nauji bibliografiniai ịrašai. El. leidinių bibliografiniu ịrašu skaičius išaugo 444, o skenuotų leidinių turinių ir viršelių vaizdų 2954 vnt. (6.24 pav.). Ataskaitiniais metais turiniai ir viršeliai buvo peržiūrèti net 34766 kartus.

Pagal ịvestu i el. katalogą ir ị lokalias DB leidinių ỉrašų skaičių patenkame i geriausių LABT katalogu penketuką, o pagal per metus ịvestų naujų bibliografiniu i̇rašų skaičių esame treti tarp LABT bibliotekų.

Universiteto turimų spausdintų leidinių matomumui didinti el. kataloge užregistruoti Informacinių sistemų laboratorijos, Aplinkos apsaugos katedros ir Aplinkos apsaugos instituto leidiniai - iš viso 414 pav., 690 vnt.

6.12 lentelè. Bibliotekos 2014 m. kiekybiniai rodikliai

\begin{tabular}{|c|c|}
\hline Veiklos sritis & Iš viso $2014 \mathrm{~m}$. \\
\hline Bibliotekos leidinių fondas, pavadinimai/vienetai & 109329 / 547928 \\
\hline Atviruose fonduose, pavadinimai / vienetai & 37589 / 97305 \\
\hline Isigyta spausdintų leidinių per metus, pavadinimai / vienetai & $1554 / 4051$ \\
\hline Nurašyta per metus, pavadinimai / vienetai & $510 / 24049$ \\
\hline Elektroniniai ištekliai DB (el. knygos), pavadinimai & 254827 \\
\hline Registruotų skaitytojų skaičius & 18233 \\
\hline Apsilankymų skaičius, virtualių / fizinių & 1244066 / 132804 \\
\hline Spausdintų leidinių išduotis & 173605 \\
\hline Skaityklų skaičius & 13 \\
\hline Darbo vietų skaičius (kompiuterizuotų) & $446(63)$ \\
\hline Etatų skaičius & 54,50 \\
\hline
\end{tabular}

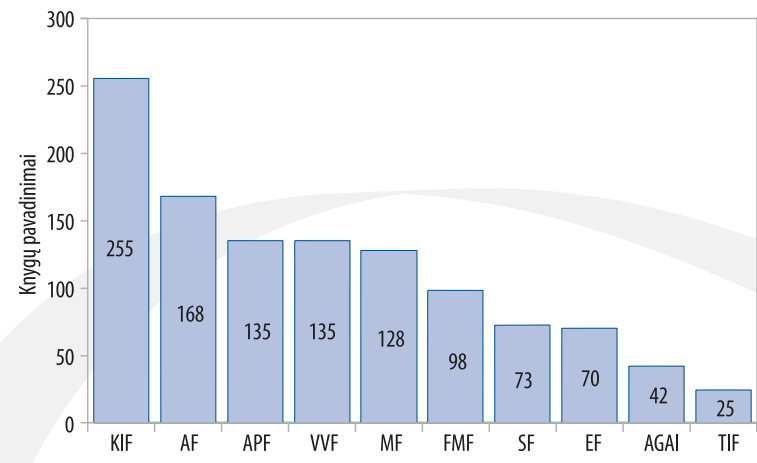

6.22 pav. Fakultetų užsakytų naujų knygų skaičius 2014 m.

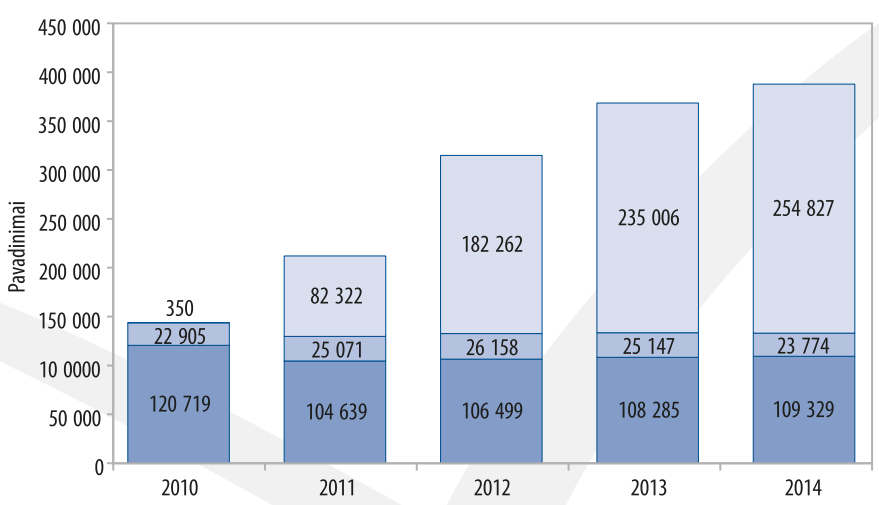

$\square$ Tradiciniai leidiniai (pavad.) $\square$ El. periodiniai leidiniai (pavad.) $\square$ El. knygos (pavad.)

6.23 pav. Informacijos išteklių kaita 2010-2014 m. 


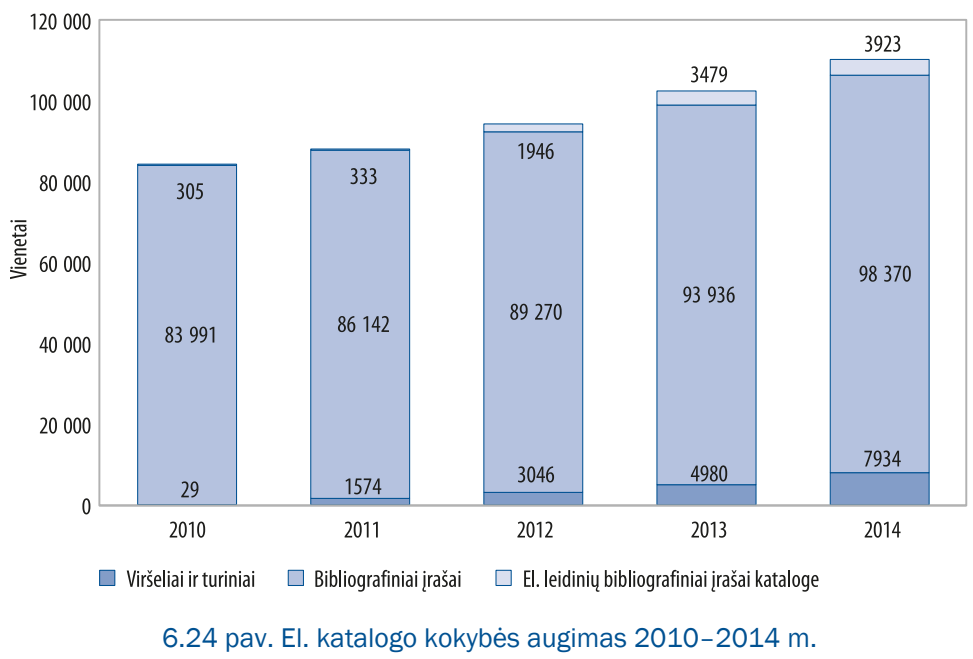

Skaitytojų aptarnavimas ir paslaugos. 2014 m. gauta 8251 informacinė užklausa. Iš jų 6030 - citavimo ir statistinès rodiklių analizès klausimais. Tai sudarè 73 \% visų gautu užklausų. Naudojantis Thomson Reuters WoS DB, atliktos universiteto vardu paskelbtu publikacijų bibliometrinès analizès:

- 2013 m. išleistų publikacijų citavimo (išanalizuoti 2408 autorių publikacijų ir 63 katedrų bei mokslo padalinių kolektyviniai rodikliai);

- Lietuvos ir užsienio leidinių, cituojančių VGTU publikacijas (išanalizuotos 2013 m. 335 publikacijos);

- pagal mokslo (meno) publikaciju vertinimo kriterijus (išanalizuoti 164 žurnalai, kuriuose VGTU autoriai 2013 m. publikavo straipsnius).

Remiantis PDB per metus parengti 753 personaliniai autorių publikaciju sąrašai, kurie buvo teikti atestacijoms, konkursams, pedagoginiams vardams suteikti ir kitoms universitete vykdomoms procedūroms. Siekiant užtikrinti pildomos PDB išsamumą ir tikslumą, autorių pateikiami duomenys lyginti su WoS DB pateikiamais duomenimis.

Ataskaitiniais metais parengtos septynios bibliografinès rodyklès: prof. R. Karkausko, prof. A. Kaulakienės, prof. M. Burinskienės, prof. A. Daniūno, prof. K. Jakovlevo-Mateckio, prof. P. Čyro ir akademiko prof. E. K. Zavadsko.

Lietuvos elektroninių tezių ir disertacijų informacinèje sistemoje (ETD IS) yra pateikti 2432 universiteto doktorantų ir magistrų baigiamieji darbai. Per 2014 m. j ETD IS buvo įkelti 292 darbai: 50 disertaciju, 30 disertaciju santraukų ir 212 baigiamujų magistro darbų. Pagal ị archyvą ịkeltų daktaro disertacijų ir ju santraukų skaičių VGTU yra antroje vietoje tarp akademinių institucijų. Ataskaitiniais metais darbai buvo skaityti 241684 kartus, ju panauda, palyginti su 2013 m., išaugo 17,2 \%.

Lyginant su 2013 m., registruotų skaitytojų padaugejo 2106, o apsilankymų skaičius - 24099 lankytojais (6.12 lentelè). 24/7 skaitykloje nakti apsilankè 5236 lankytojai. Lyginant su 2013 m., lankytojų nakties metu padaugèjo 873-imis. Per metus studentams buvo išduota 331 nauja iejjimo kortelè, pratęstos 364 elektroninès ièjimo kortelès.

Bibliotekos kompiuteriais pasinaudojo 14081 lankytojas, asmeniniais - 11059 lankytojai. 2014 m. sulaukta 25818 sèkmingu prisijungimu prie bibliotekoje esančio bevielio tinklo.

Ataskaitiniais metais teikiamos el. paslaugos suteiktos 1244066 virtualiems lankytojams. Interneto svetainès lankytojai buvo iš 108 šalių: iš mobiliuju ịrenginių prisijungta 7972 kartus, iš planšetinių kompiuterių 1134 kartus.

2014 m. BUS el. paslaugą plètojo šešiolika darbuotojų. Aktyvuoti 19296 dèstytojų prie studijų modulių studentams rekomenduojami informacijos ištekliai. Šia el. paslauga per metus pasinaudojo 22165 lankytojai iš 81 šalies.

Siekiant didinti visų bibliotekos teikiamų paslaugų matomumą ir panaudą, akademinei bendruomenei bei studentams organizavome individualias ir grupines konsultacijas:

- jvadinès informacinio raštingumo paskaitos visų fakultetu pirmo kurso studentams;

- citavimas ir literatūros sąrašų sudarymas baigiamajame darbe;

- Lietuvos moksliniu biblioteku asociacijos (LMBA) vykdomo projekto eMoDB.LT2 mokymai. Mokytos dvi mokslininkų ir viena magistrantu grupès.

Iš viso per metus suorganizuotos 56 paskaitos (112 akad. val.), dveji mokymai (16 akad. val.), kuriuose dalyvavo 1126 klausytojai: 26 dèstytojai, 21 mokslininkas ir 1079 studentai. 
2014 m. lankytojams teikiamomis mokamos paslaugomis pasinaudojo 4917 lankytojų. Už paslaugas gauta apie 40 tūkst. Lt pajamų.

Leidinių išduotis ir elektroninių išteklių panauda. 2014 m. kiekvienas registruotas skaitytojas vidutiniškai i namus paèmé po 10 dokumentų, o kiekvienas akademinės bendruomenès narys (dèstytojas, mokslo darbuotojas, studentas) vidutiniškai atsisiuntė po 118 viso teksto el. dokumentu (6.12 lentelè).

El. dokumentų skaitomumas / panauda 2014 m. buvo aštuonis kartus didesnis nei spausdintų dokumentų (6.25 pav.).

Bibliotekos matomumo didinimas. Bibliotekos svetainè buvo nuolat atnaujinama ir pildoma aktualia informacija - paskelbtos 204 naujienos lietuvių ir anglų kalbomis.

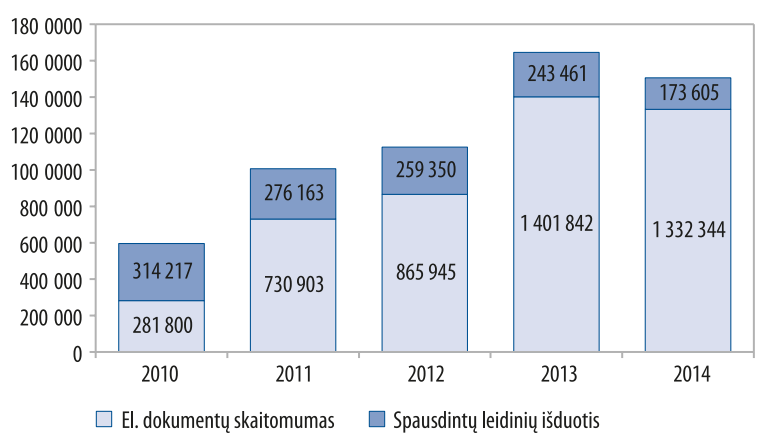

6.25 pav. Spausdintų ir el. išteklių panauda $2010-2014 \mathrm{~m}$.

Naujausia informacija apie paslaugas ir renginius pateikiama populiariuose socialiniuose tinklalapiuose Facebook, Twitter ir Flickr, o virtualios parodos ir mokomieji gidai, aiškinantys, kaip užsisakyti knygas, naudotis DB ir kt. ištekliais - Youtube. Per metus buvo paskelbtos 479 informacinès žinutès, kurias vartotojai peržiūrèjo 72475 kartus, o vaizdo ịrašai peržiūrèti 1694 kartus. 2014 m. bibliotekos interneto svetainèje buvo nuolat teikiamos intelektinès nuosavybės organizacijų WIPO, EPO, VPB ir kitų patentinių tarnybų naujienos. Teiktos konsultacijos apie patentų klasifikaciją, prekių ženklus, inovacijas ir paieškas pasaulinėse patentų DB. Parengta 2011- 2013 metu Lietuvos universitetu patentavimo dinamikos analizè.

\section{Leidyba}

Leidykla „Technika“ - šiuolaikiška akademinè leidykla, turinti gilias leidybos tradicijas. Leidykla leidžia technologiju, gamtos, socialinių ir humanitarinių mokslų studijų leidinius, mokslo žurnalus, monografijas, daktaro disertacijas ir kitus akademinius leidinius. Visi studijų ir mokslo leidiniai yra recenzuojami, redaguojami ir leidžiami knygine bei elektronine forma. Visi leidiniai, išleisti nuo 2010 metų iki dabar, yra ir elektroninio formato, ankstesnių metų leidiniai skaitmeninami prireikus.

6.13 lentelè. 2010-2014 m. išleisti leidyklos „Technika“ leidiniai

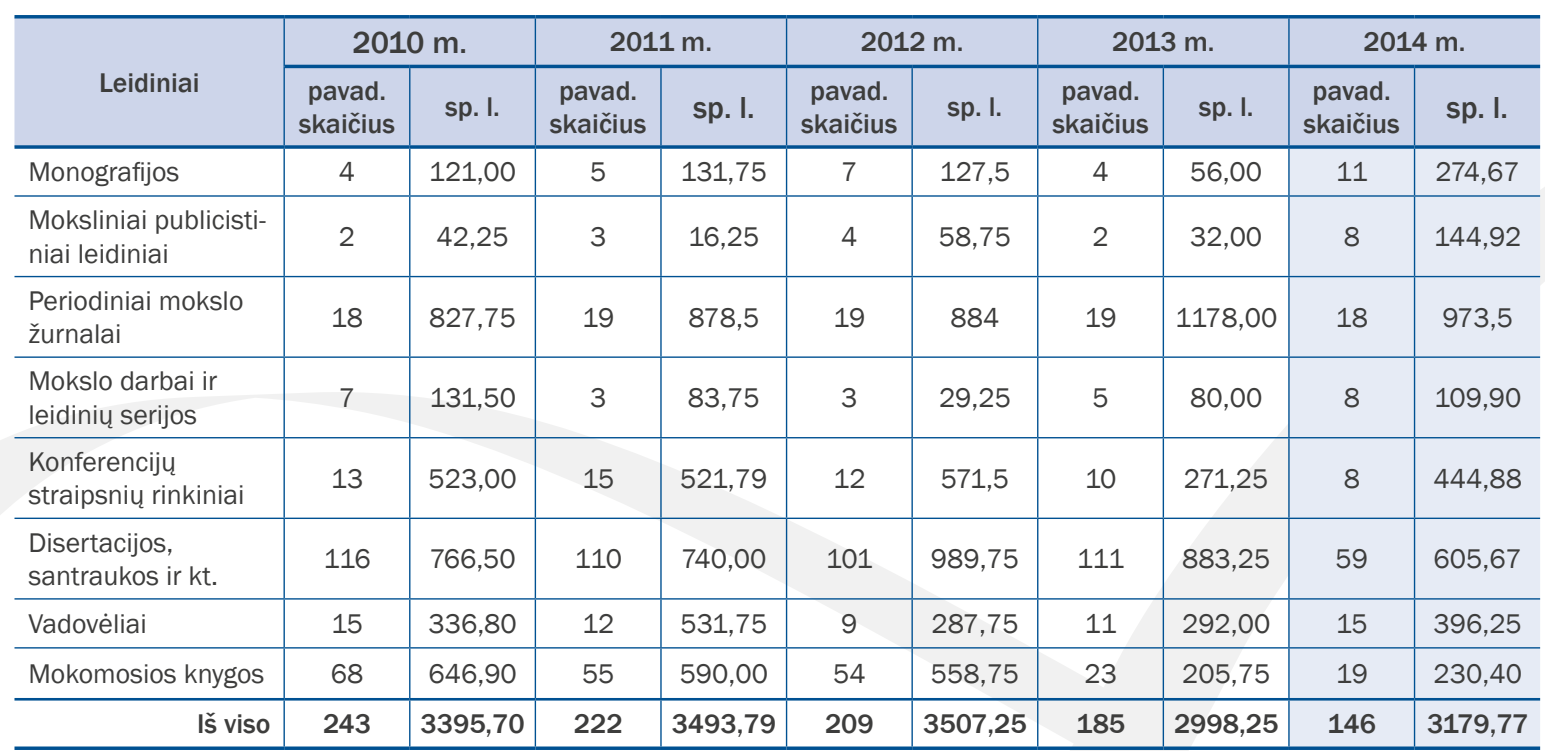


Studijų leidinių leidyba. 2014 m. studijų leidinių kalbos kokybei skiriama daug dėmesio: rankraščiai ne tik redaguojami, bet ir tvarkomi dalykiniu požiūriu, derinant su autoriais atitinkamos srities terminiją pagal Valstybinès lietuvių kalbos komisijos (VLKK) reikalavimus, tuo puoselejjant akademinès kalbos kultūrą ir lietuviškosios mokslo terminijos įtvirtinimą.

Daug dėmesio skirta vadovèlių kalbos kokybei gerinti. Bendradarbiauta su VLKK, kuri rūpinasi kalbos būkle švietimo įstaigose ir atlieka reguliarią išleistų aukštujų mokyklų vadovẻlių kalbos taisyklingumo patikrą. ! gautas komisijos rekomendacijas atsižvelgiama, tuo remiantis keliama kalbos redaktorių kvalifikacija. Prie to prisideda ir dalyvavimas svarbiuose renginiuose - Leidybos skyriaus darbuotojai $2014 \mathrm{~m}$. dalyvavo Seime vykusioje Seimo ir Valstybinès lietuvių kalbos komisijos (VLKK) surengtoje konferencijoje „Valstybinės kalbos politika: ¡̌žvalgos ir gairès“.

Kalbos redaktorių ir kitų leidyklos darbuotojų komunikacija su autoriais palaikoma šiuolaikiškomis priemonėmis, visus kilusius klausimus sprendžiant ir neakivaizdžiai. Nemažai dėmesio skiriama daktaro disertacijų kokybei - doktorantai nuolat konsultuojami kalbos klausimais.

Leidykla imasi leisti i lietuvių kalbą išverstas pasaulyje pripažintas knygas - tai M. Heideggerio veikalas „Būtis ir laikas“ (vertè T. Kačerauskas) ir R. Floridos vadovèlis „Kūrybinès klasės iškilimas“ (vertè J. Barevičiūtė). Tai rimtas iššūkis leidyklai, siekiančiai užtikrinti naujoms studijų programoms reikalingą kokybišką profesionalios verstinès literatūros leidybą.

Mokslo žurnalų leidyba. 2014 m. leidykla leido 18 recenzuojamų mokslo žurnalų: iš jų 8 - technologijos ir gamtos mokslų, 5 - socialinių, 4 - humanitarinių mokslų ir 1 - tarpdalykinis. Visi VGTU žurnalai ịtraukti i ProQuest, EBSCO, GALE ir IndexCopernicus bazes, 13 iš jų indeksuojami Scopus, 8 - Web of Science. Dauguma VGTU žurnalu indeksuoti specializuotose duomenų bazėse. 12 mokslo žurnalų, leidžiamu su Taylor\& Francis, naudoja elektronines sistemas (ScholarOne Manuscript - recenzuoti, CATS - leidybai tiesioginės prijungties režimu administruoti) ir mokslo žurnalų leidybos platformą www.tandfonline.com. Nuolat tobulinami mokslo žurnalų elektroninio publikavimo portalai (Open Journal Systems) - 2014 m. prie viso sistemų naudojimo perèjo humanitarinių mokslų žurnalai.

Nuolat gilinamos žinios apie žurnalų leidybos etiką - intensyviai ieškoma naujos informacijos, analizuojama specializuota literatūra. Kolektyve rengiamos diskusijos ir aptarimai, siekiant pasidalyti, itvirtinti ir praktiškai pritaikyti sukauptas žinias. Siekiant puoselèti ir užtikrinti aukštus žurnalų leidybos etikos standartus, teikiamos individualios konsultacijos žurnalų redaktoriams ir straipsnių autoriams autorių teisių ir kitais žurnalų leidybos etikos klausimais.

Konferencijų rinkinių leidyba. Sėkmingai tiek elektronine, tiek tradicine forma išleista keletas konferencijų straipsnių rinkinių, tarp ju - didelès tarptautinès konferencijos Business and Management ir Environmental Engineering, kurios buvo pateiktos prestižinėms duomenu bazėms, o pastaroji priimta i Web of Science. Konferencijoms taip pat buvo parengta kokybiška ir vaizdinga dalijamoji medžiaga. Tarptautinè konferencija Mechatronic Systems and Materials (MSM-2013) buvo išleista su Trans Tech Publications Inc. Taip pat tęsiama vis daugiau dėmesio sulaukiančios Jaunujų mokslininkų serijos konferencijų leidyba.

VGTU talpykla (http://dspace.vgtu.lt) idiegta 2011 m. pradžioje, siekiant sistemingai kaupti universiteto darbuotoju mokslo ir studiju publikacijas. 2015 m. pradžioje VGTU talpykloje buvo 1632 publikacijos, daugiausia ju - mokslo (disertacijos, monografijos, konferencijų straipsnių rinkiniai). Didele dalis studijų leidinių, esančių VGTU talpykloje, tai leidiniai, parengti ir išleisti vykdant ES projektus. Visi jie laisvai prieinami skaitytojams. Tik nedidelè dalis talpykloje esančių publikacijų prieinama VGTU bendruomenei universiteto tinkle arba per nuotolinès prieigos paslaugą (Virtual Private Network, VPN). Talpykloje esančias publikacijas indeksuoja akademinè duomenų bazè Google Scholar ir taip padidina VGTU mokslininkų matomumą tarptautinèje akademinèje bendruomenèje. Universiteto talpyklą 2014 m. aplankẻ 27350 unikalių vartotojų iš skirtingų pasaulio šalių. Dar vienas talpyklos pranašumas - kiekvienas autorius gali matyti, kiek kartu jo leidinys buvo skaitytas ir kuriame pasaulio mieste tuo metu buvo skaitytojas.

Elektroninès knygos. Dauguma išleistų leidinių pateikiami elektroninių knygų portale (http://ebooks.vgtu.It), idiegtame 2010 m. pradžioje. 2014 metu pabaigoje portale jau buvo 513 el. knygų. Visos portale esančios knygos yra laisvai prieinamos bendruomenei universiteto tinkle arba per VPN iš namų. 2014 m. pradėta rengti dvikalbė (lietuvių ir anglų) el. knygu portalo versija.

Elektroninès knygos daugiausia platinamos per instituciju prenumeratas. Po aktyvaus 2014 m. darbo su Lietuvos bibliotekomis buvo ne tik atnaujintos esamos, bet ir pasirašytos naujos sutartys dèl el. leidinių prenumeratos, pagal kurias 2015 m. VGTU el. knygas prenumeruos 18 šalies bibliotekų. Elektroninių knygu pardavimo mastas, lyginant su 2013 m., 2014 m. padidejjo 3,15\%. 
Spausdintų leidinių poligrafinè kokybè. $2014 \mathrm{~m}$. daug dėmesio buvo skirta poligrafinei kokybei. Mokomosioms knygoms ir informaciniams leidiniams naudojamas popierius, kurio kokybès ir kainos santykis yra optimalus. Reprezentaciniams leidiniams, vadovèliams, monografijoms ir kt. dažniausiai renkamės aukštos klasės, purų, be medienos masės popierių, kuris tausoja gamtą, nekeičia atspalvio, yra stiprus ir ilgaamžis. Reprezentaciniai leidiniai apipavidalinami įdomesniu įrišimo būdu, atsakingai parenkant laminato blizgumą, kaptalo spalvą, o norint išskirti ir pabrèžti kai kurias detales, joms parenkamas UV lakavimas, folijavimas arba kongrevinis isspaudas. 2014 m. išleidome VGTU teatro studijos „Palėpe““ pjesių rinkini „Šis tas apie mūsų Motiną“, kuriam parinktas atviros nugarèlès su ryškiais siūlais įrišimas.

Kvalifikacijos kèlimas. Leidyklos darbuotojai kèlè kvalifikaciją, sėmėsi patirties ir atstovavo VGTU tarptautiniuose seminaruose ir stažuotėse. Elektroninės leidybos skyriaus specialistè dalyvavo Danijoje vykusioje Taylor\&Francis konferencijoje apie mokslo žurnalų sklaidą. Elektroninès leidybos skyriaus darbuotojai taip pat dalyvavo internetiniuose seminaruose. Tarptautinèje Frankfurto knygu mugèje buvo dalijamasi patirtimi, susitikta su esamais partneriais stiprinant bendradarbiavimą ir užmegzti nauji naudingi kontaktai leidybos paslaugų ir mokslo produkcijos sklaidos srityse.

Sklaida, švietèjiška veikla, tarptautinis pripažinimas. Leidykla kaip ir kasmet aktyviai dalyvavo Tarptautinėje Vilniaus knygu mugejje, kur pristatè aktualius leidinius ir surengè daug dėmesio sulaukusias diskusijas apie aukštujų mokyklų vadovèlius. Universiteto leidinių sklaida plačiajai visuomenei taip pat buvo vykdoma per naujų leidinių sutiktuves Klaipėdoje ir Panevėžyje - 2014 metų Lietuvos kultūros sostinèje.

Universitete kartu su Lietuvos autorių teisių gynimo asociacija (LATGA) ir Lietuvos mokslinių biblioteku asociacija buvo suorganizuotas itin svarbus seminaras autoriams ir visai universiteto bendruomenei apie autorių teises ir kūrybinių bendrijų licencijas. Šis seminaras buvo didelis žingsnis dar kokybiškesnių leidinių ir didesnio profesionalumo link, kartu ir postūmis laikytis sąžiningos mokslo praktikos. 2014 m. pasirodè pirmieji analogo šalyje neturintys leidyklos vadovẻliai su kūrybinių bendrijų licencijomis ir leidimais publikuoti iliustracinę medžiagą.

2014 m. VGTU leidykla „Technika“ tapo atvirosios prieigos mokslinių leidejjų asociacijos OASPA nare. Leidyklos direktorè buvo išrinkta tarptautinès organizacijos CrossRef valdybos nare trejų metu kadencijai.

Knygos platinamos VGTU knygyne „Technika“, UAB „Patogu pirkti“, UAB „Knygininkas“, UAB „Humanitas“, UAB „ALG knygynai“ („Pegasas“) ir kt. 2014 m. dèl platinimo pasirašyta dar keletas sutarčiu su: „Vagos“ knygynu tinklu UAB „Vagos prekyba“, „Žiburio“ knygynu, UAB „Alma littera sprendimai“ ir UAB „SHI“. Spausdintu knygu pardavimo mastas, lyginant su 2013 m., 2014 m. padidejjo 4,2 \%.

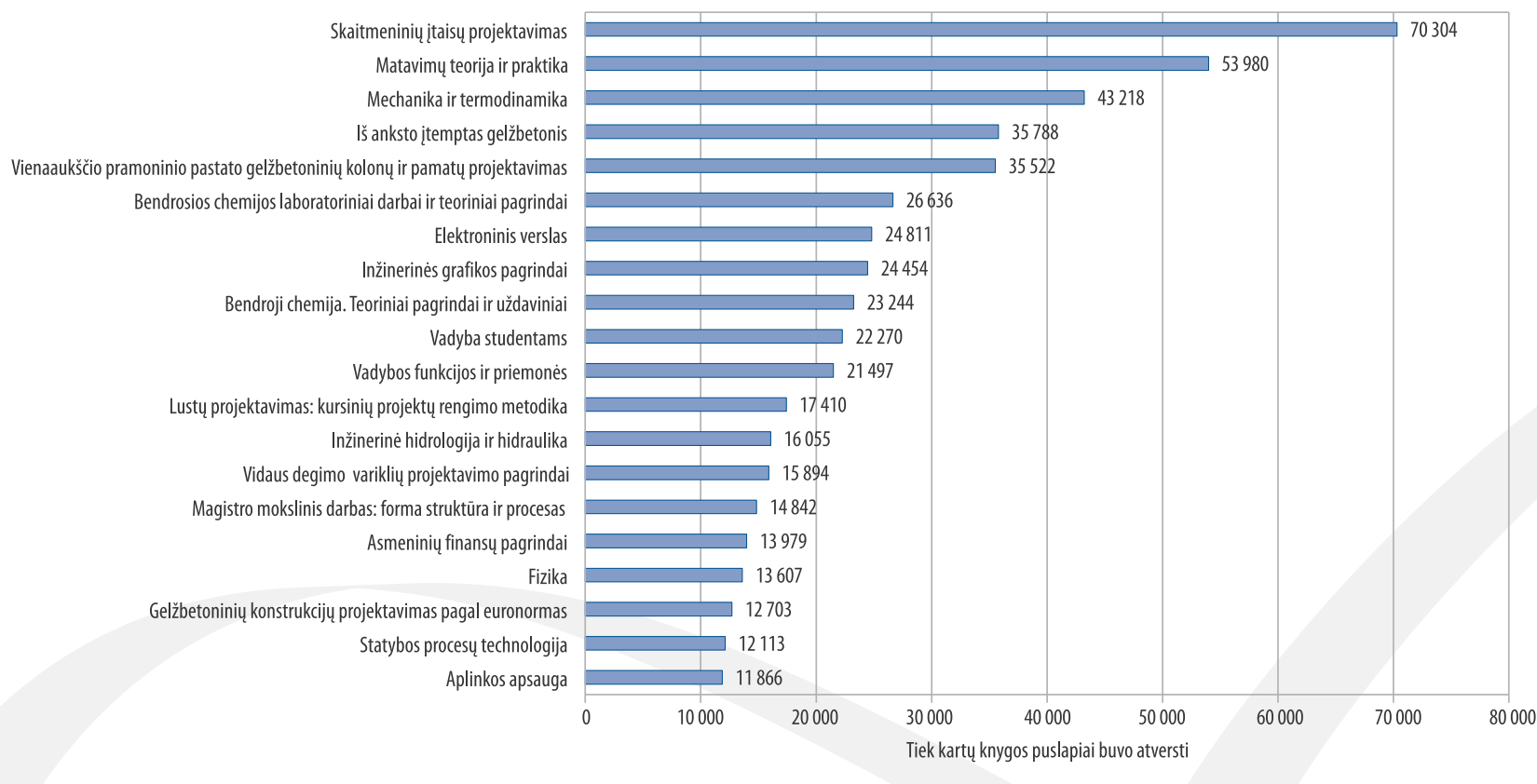

6.26 pav. Skaitomiausios 2014 m. knygos 


\section{Informacinès technologijos}

Be plataus informacinių technologijų taikymo šiandien neįsivaizduojama bet kokios organizacijos, o tuo labiau universiteto veikla. $2014 \mathrm{~m}$. buvo toliau plètojama $2013 \mathrm{~m}$. atlikta universiteto IT ūkio centralizacija, plètėsi naujai įkurto IT padalinio - Informacinių technologijų ir sistemų centro (ITSC) veikla, teikiant ịvairiapusiškas IT paslaugas universiteto bendruomenei. lgyvendindamas kokybės vadybos sistemos nuostatas ITSC nustatė teikiamų paslaugų kokybės kriterijus ir juos apibūdinančius rodiklius. Visos IT paslaugos yra periodiškai vertinamos pagal šių rodiklių reikšmes.

IT priežiūra. $2014 \mathrm{~m}$. i centralizuotą IT priežiūrą buvo ịtraukti nauji padaliniai - tai biblioteka ir Antano Gustaičio aviacijos institutas. Vidutiniškai per mènesi sulaukiami 665 ịvairaus pobūdžio kreipiniai. Aktyviausiai naudotojai ieško pagalbos rugsèjo ir sausio mèn., tuomet kreipinių skaičius išauga dvigubai. Jų kiekybini pasiskirstymą per metus iliustruoja 6.27 pav.

Pagal kreipinių turini kas antras kreipinys susijęs su įvairiomis programinès ir techninès ịrangos incidentais darbo vietoje, kitą pusę sudaro standartiniai kreipiniai dèl informacinių sistemų, tinklalapių ar kompiuterių tinklų ir teikiamų paslaugu (6.28 pav.).

Kreipiniai, ju vykdymas ir vertinimas registruojami bei administruojami specialiomis programinėmis priemonėmis, apie sprendimo eigą naudotojai informuojami el. laiškais. 87,3 \% naudotojų, vertinusių ITSC darbuotoju reagavimą i jų problemas, ivertino aukščiausiai, t. y. labai gerai.

IS priežiūra (programavimas). Centralizuota IT priežiūros paslauga apima ne tik darbo vietų, bet ir informacinių sistemų priežiūrą.

2014 m. universiteto padaliniai pateikė 2141 paraišką ìvairiems informacinių sistemu programavimo darbams. Iš jų iki galo buvo atlikta 1660 (77,5\%).

Informacinių sistemų vystymo ir priežiūros paslauga teikiama plačiai naudojant lanksčiojo programavimo projektų valdymo metodiką „Agile Scrum“, vadovaujant „Scrum Master“ ekspertui. Toks pasirinkimas leidžia stebėti kasdienius rezultatus ir operatyviai bei lanksčiai reaguoti i užsakovų poreikius. Priežiūros darbų eiga ir būklè realiuoju laiku apie darbų būklę skelbiama VGTU intranete (6.29 pav.).

Vienas matomiausių 2014 metų IT vystymo projektų buvo naujos VGTU interneto svetainès sukūrimas. Tai ne tik atnaujino VGTU veidą, bet kartu ir informacijos interaktyvumą: integruotos mokslo ir studijų informacinès sistemos, teikiamos paslaugos verslui pateikiamos struktūriškai ir vienoje vietoje, pabrėžiamas VGTU aktyvumas ịvairiose srityje, išsaugotas fakultetų autonomiškumas.

2014 m. buvo vykdomi vidinio VGTU bendruomenės tinklalapio - intraneto tobulinimo darbai. Buvo sukurtos padalinių erdvės, kurios leidžia dalytis vidiniais dokumentais, naudotis šiuolaikiška priminimu sistema, informuoja apie pasikeitimus. Sukurtas naujienlaiškis, labai pagerinęs vidinę VGTU komunikaciją.

Pradėtas bendras VGTU veiklos analitikos projektas, siekiant automatizuoti analitinès veiklos ir kokybės valdymo sistemos rodiklius. Sukurti informaciniai „Business - Intelligence“ kubai ir jų tarpusavio ryšiai, kurių tikslas gauti žinių, svarbių universiteto strategijai, operaciniams, taktiniams veiksmams, strateginiams sprendimams.

Kitos IT paslaugos. Viena plačiausiai naudojamų universitete IT paslaugu yra tarnybinio elektroninio pašto paslauga, teikiama visiems universiteto darbuotojams ir studentams. 2013 m., atlikus elektroninio pašto pertvarką, darbuotojams buvo skirta Microsoft Exchange platforma, o studentams - Google Gmail. 2014 m. studentų el. pašto naudojimo aktyvumas padidejo, daugiausia tai pastebima gegužès ir gruodžio mènesiais. VGTU studentu el. pašto naudojimo dinamika pateikta 6.30 pav.

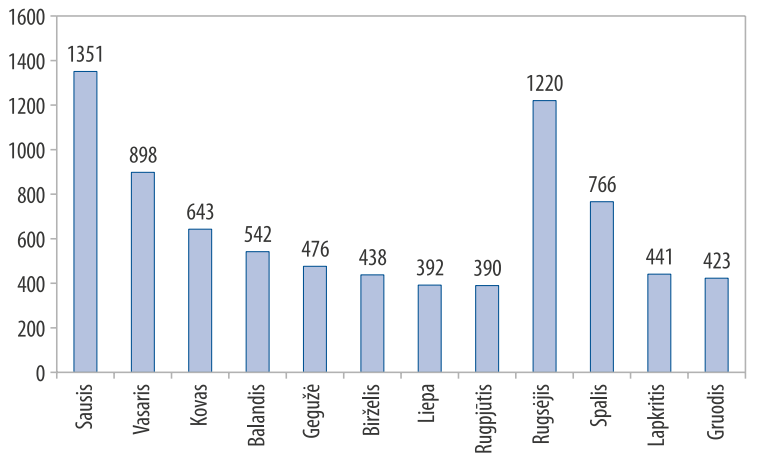

6.27 pav. Kiekybinis kreipinių pasiskirstymas mènesiais per metus

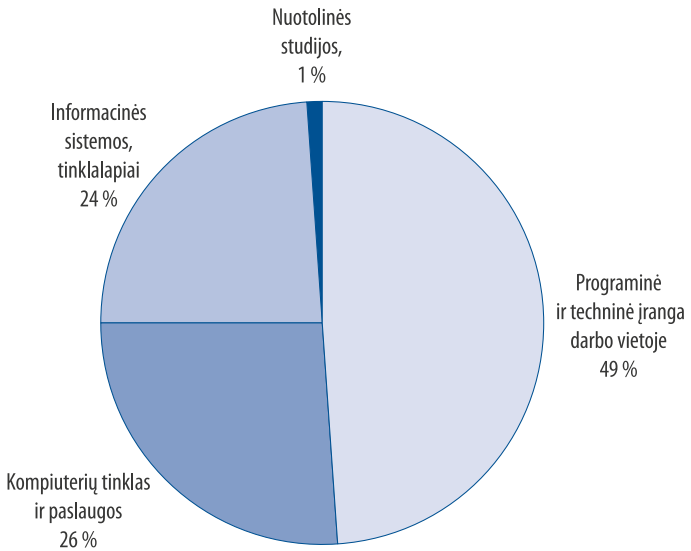

6.28 pav. Kreipinių pasiskirstymas pagal jų turini 
Populiarèjant informacinių technologijų taikymui įvairiausiose veiklos srityse, auga ir piktavališkų incidentų. Kasmet daugeja kenkejjiškos programinès įrangos, kuri verčia visas organizacijas stiprinti savo veiklai svarbių informacinių technologijų apsaugą. Dèl šių priežasčių ir tęsiant darbuotojų el. pašto pertvarką, 2014 m. buvo ¡diegta naujos kartos apsaugos sistema. Ji jau pirmaisiais mėnesiais užblokavo daugiau nei 400000 kenkejjiško pobūdžio el. laiškų. Didžiausias piktavališkų el. laiškų intensyvumas užfiksuotas bandant pristatyti 450 laiškų per minutę. Vieno mènesio užblokuotų kenkejjiškų el. laiškų grafikas pateiktas 6.31 pav.

Mobilumas - viena iš vyraujančių šiuolaikinių informacinių technologijų vystymosi tendencijų. Vis daugiau studentų ir dėstytojų naudoja ivvairius išmaniuosius įrenginius, reikalaujančius internetinio ryšio. Pasaulinès tendencijos rodo, kad mobiliujų ịrenginių daugės ir spartaus belaidžio tinklo poreikis didès. Atsižvelgdamas ¡ šias tendencijas ir darbuotojų bei studentų poreikius, ITSC pradėjo aktyvią belaidžio tinklo plètrą VGTU patalpose. Visuose universiteto padaliniuose veikia 22 belaidžio ryšio zonos, kurias aptarnauja beveik 200 belaidžio tinklo prieigos stotelių. 2014 m. spartusis belaidis tinklas irrengtas dviejuose (Nr. 1 ir Nr. 5) bendrabučiuose. Parengtas 2015 metų plètros planas, kuriame numatytas îrengti 160 papildomų belaidžio tinklo prieigos stotelių.

VGTU sėkmingai dalyvauja bendro prisijungimo prie belaidžio tinklo Europos universitetuose projekte Eduroam. Mūsų studentai tuo pačiu prisijungimo vardu ir slaptažodžiu jungiasi prie belaidžio tinklo ne tik VGTU patalpose, bet ir kituose Europos universitetuose išvykų ir stažuočių metu.

Analogišku galimybių turi ir iš kitų Europos universitetų pas mus atvykę dėstytojai ir studentai. $2014 \mathrm{~m}$. VGTU studentai ir darbuotojai i belaidi tinklą jungési per 6 milijonų kartų, iš jų daugiau nei 3 milijonus kartų buvo prisijungta VGTU teritorijoje ir daugiau nei 3 milijonus kartų prisijungè VGTU atstovai, išvykę i kitas Eduroam tinklui priklausančias institucijas. VGTU teritorijoje per 7 milijonus kartų jungėsi pas mus atvykusių kitų Lietuvos ir Europos akademinių institucijų atstovų. Kiek kitų institucijų unikalių naudotoju jungėsi universitetuose 2014 m. pateikta 6.32 pav. ir 6.33 pav. - kiek Lietuvos universitetų naudotojų jungėsi per Eduroam kitose institucijose. Iš jų matome, kad VGTU šiame projekte yra vieni aktyviausių, ir tai rodo augantị mūsų universiteto tarptautiškumo lygi.

\begin{tabular}{|c|c|c|c|c|c|}
\hline \multicolumn{6}{|c|}{2014 IV ketvirtis } \\
\hline $\begin{array}{l}\text { Užduoties } \\
\text { numeris }\end{array}$ & Posistemis & Užduoties pavadinimas & $\begin{array}{l}\text { Planuojamo } \\
\text { užbaigimo data }\end{array}$ & Užsakovas & Atlikta \\
\hline \#3658 & Personalo posistemis & Kintamosios dalies įsakymo parengimas & - & Rita Kudzienè & $30 \%$ \\
\hline \#4699 & Personalo posistemis & Apskaitos informacijos pakeitimas nuo 2014-12-01 & - & Rita Kudzinienè & $60 \%$ \\
\hline$\# 3424$ & Studijų posistemis & Studijų programų 5 gebëjimų sistema & - & Janita Žilinskienè & $100 \%$ \\
\hline \#3799 & Konferencijų svetainès & Tinklalapio sukūrimas KIF organizuojamai tarptautinei konferencijai CreativeConf.vgtu.It & 2014-10-09 & Vytenis Mockus & $10 \%$ \\
\hline$\# 3238$ & Moodle & VGTU darbuotojų/studentų el. paštas turi būti pakeistas j̣ tarnybinị & - & Roma Oškutienè & $90 \%$ \\
\hline$\# 3737$ & Personalo posistemis & Paruošti darbuotojų sąrašă, kurie pagrindinès sutarties atleidimo metu turejo papildomas darbo sutartis & - & Marija Senkevič & $60 \%$ \\
\hline$\# 3839$ & Finansų posistemis & Duomenų formavimo pakeitimai perkeliant DU priskaitymus iš Liemsio informacinès sistemos & - & Daiva Kuliominė & $100 \%$ \\
\hline$\# 3673$ & Mokslo posistemis & Atestacinių kortelių antraščị parengimas & - & Vaidotas Vaišis & $0 \%$ \\
\hline \#3810 & Personalo posistemis & Surinkti duomenys pagal parengta užsakymą MULTIRANK2 & - & Marija Senkevič & $30 \%$ \\
\hline
\end{tabular}

6.29 pav. Ataskaita apie IS priežiūros darbų vykdymą

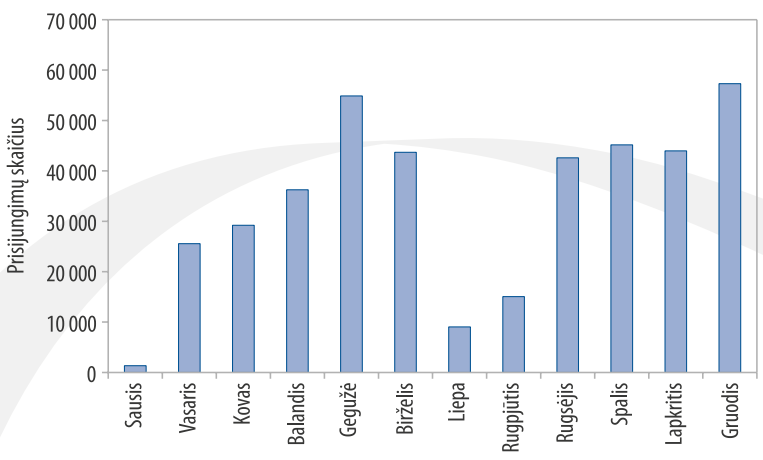

6.30 pav. VGTU studentų el. pašto aktyvumo dinamika

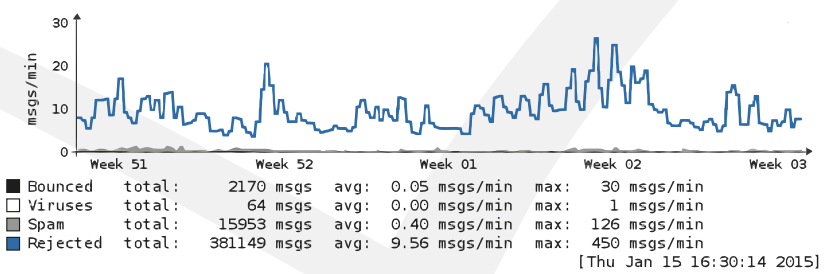

6.31 pav. Užblokuotų kenkejjiškų el. laiškų grafikas 
Kokybiškas informacinių paslaugų teikimas negalimas be išvystytos informacinių technologijų infrastruktūros. Ją sudaro telekomunikacinis tinklas, jungiantis visus universiteto pastatus šviesolaidinėmis ryšio linijomis, per 100 serverių ir 6 duomenu saugyklos, kurių bendra naudinga talpa yra 124 terabaitai, daugiau nei 2 tūkstančiai kompiuterių darbo vietose ir kompiuterių klasėse. 2013 m. 249 darbo vietos buvo atnaujintos stacionariais kompiuteriais, iš ju 98 - kompiuterių klasėse, isigyti 109 nešiojamieji kompiuteriai.

Siekiant mažinti vėsinimo, elektros ir fizinès vietos sąnaudas, serveriai yra virtualizuojami. Tam naudojamos Hyper-V, VMware ir Linux konteinerių technologijos. Serverių virtualizacija siekia 85 \% turimos infrastruktūros ir šis rodiklis nuolatos gerinamas. Ši infrastruktūra leidžia universiteto darbuotojams ir studentams naudoti didžiulius internetinių duomenų kiekius. Duomenų, siunčiamų ir gaunamų iš Lietuvos bei kitų pasaulio valstybių, srautu dinamika per pastaruosius penkerius metus pateikta 6.34 pav.

2014 metų rudeni universitete pradèjo veikti centralizuota spausdinimo / kopijavimo / skenavimo paslauga, naudojant galingus daugiafunkcius įrenginius, išdèstytus Saulètekio centrinių rūmų 1, 4, 5 ir 6 aukštuose, taip pat bibliotekoje ir Architektūros rūmuose, kurie skirti mokamai paslaugai studentams. Tokių ịrenginių naudojimas ne tik didina spausdinimo, kopijavimo ir skenavimo darbų našumą, bet ir mažina jų savikainą. Paslaugos valdymo programinè įranga ir nauji darbuotojų pažymejjimai su RFID technologija leidžia paslaugos naudotojams paleisti spausdinimo užduotis ne tik iš savo darbo vietos, bet ir iš bet kokio įrenginio, turinčio interneto ryši ir pasiimti atspaudus iš bet kurio paslaugos daugiafunkcio įrenginio. Skenuoti dokumentai automatiškai nusiunčiami i naudotojo el. paštą. Bendra paslaugos schema pateikta 6.35 pav.

Veikla už universiteto ribų. Universiteto IT darbuotojai plačiai dalyvauja bendruose Lietuvos aukštujų mokyklų IT projektuose. Buvo sėkmingai igyvendinta sudètinga universiteto IS duomenų integracija su valstybiniais studentu bei pedagogu registrais, aktyviai dalyvauta kuriant ir testuojant eLABa sistemą. Universitetas yra vienas iš šešių Lietuvos mokslo ir studijų kompiuterių tinklo LITNET techninių centrų.

VGTU ITSC vadovui pirmininkaujant Lietuvos universitetų rektorių konferencijos IT komitetui, Rektorių konferencijos sprendimu buvo ìvardytos svarbiausios universitetų sistemos (A lygio informacinès sistemos): finansų, studijų, darbo užmokesčio ir personalo. Didelèmis pastangomis buvo pritarta bendrų minètų sistemų kūrimui ir naudojimui visuose universitetuose, siejant jas su bendromis universitetuose veikiančiomis informacinėmis sistemomis. Tai sudaro galimybes universitetams kurti ir naudoti bendrą infrastruktūrą, siekti optimaliai naudoti išteklius ateityje.

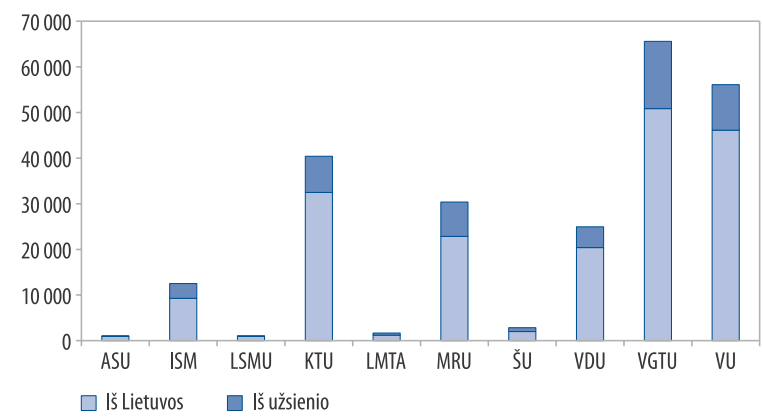

6.32 pav. Unikalūs Eduroam naudotojai, atvykę i instituciją

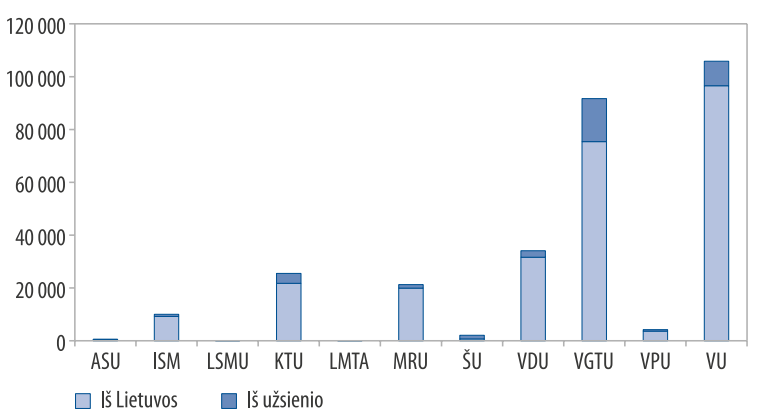

6.33 pav. Unikalūs Lietuvos universitetų Eduroam naudotojai, atvykę i kitas institucijas

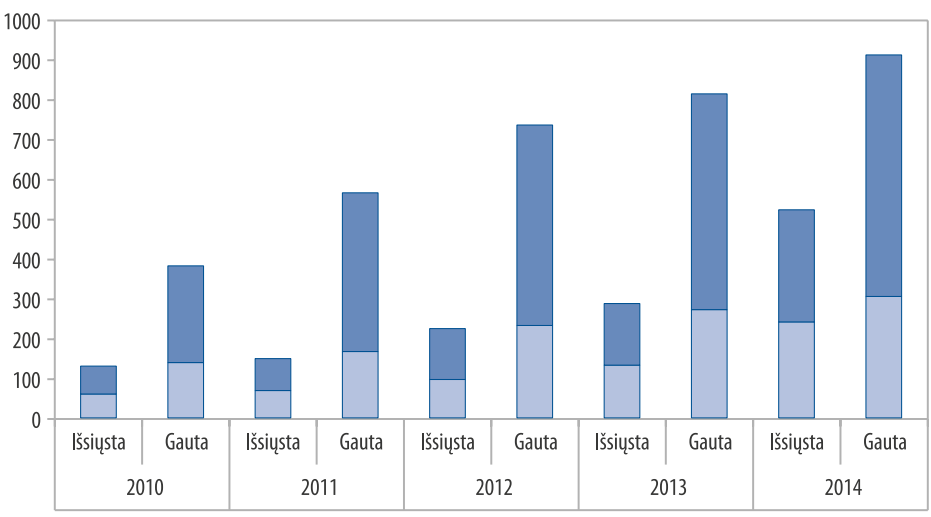

$\square$ Lietuva $\square$ Pasaulis

6.34 pav. Duomenų srautai iš/i VGTU tinklą (terabaitais) 
Siekiant decentralizuoti valdymą ir išgryninti valdymo bei paslaugu teikimo procesus, 2014 m. VGTU ITSC vadovas buvo išrinktas Lietuvos mokslo ir studijų informacinès sistemos / Institucijų mokslo ir studijų informacinès sistemos (LieMSIS/IMSIS) valdybos pirmininku. Žengtas žingsnis euro ìvedimo laikotarpiu padejjo plačiau koordinuoti pasirengimo darbus, o jiems vykdyti Lietuvos aukštosiose mokyklose buvo sutelkta specialiai deleguota VGTU ir KTU valdymo bei programuotoju komanda, kuriai vadovavo VGTU ITSC Programavimo skyriaus vadovas.

Atsižvelgiant ị informacinių technologijų poreikị rinkoje, VGTU ITSC pradėjo paruošiamuosius išorinių paslaugu teikimo darbus. Pirmoji iniciatyva - dalyvavimas pasauliniame „Live mobile“ kongrese, kuriame pristatytos programavimo metodikos, ištekliai ir potencialas. VGTU buvo vienintelis universitetas verslo aplinkos parodoje.

Taigi 2014 m. ITSC vykdè penkis ankstesniais metais pradètus ir šešis naujai inicijuotus vidinius informaciniu sistemu vystymo projektus, tarp jų: intranetas: padalinio erdvė; KVS IT modulis: KDU dalies rodikliai ir procesu valdymo rodikliai, absolventu portalas ir kt. 2014 m. užbaigti doktorantūros posistemis, absolventu, misija-karjera ir kt. projektai.

Intraneto projektas toliau bus vystomas diegiant dokumentų valdymo sistemą ir papildytas kokybejs vadybos sistemos (KVS) rodiklių stebejjimu. Bendrieji su informacinėmis technologijomis susiję rodikliai ir jų reikšmès 2014 metú pabaigoje pateikti 6.14 lentelèje.

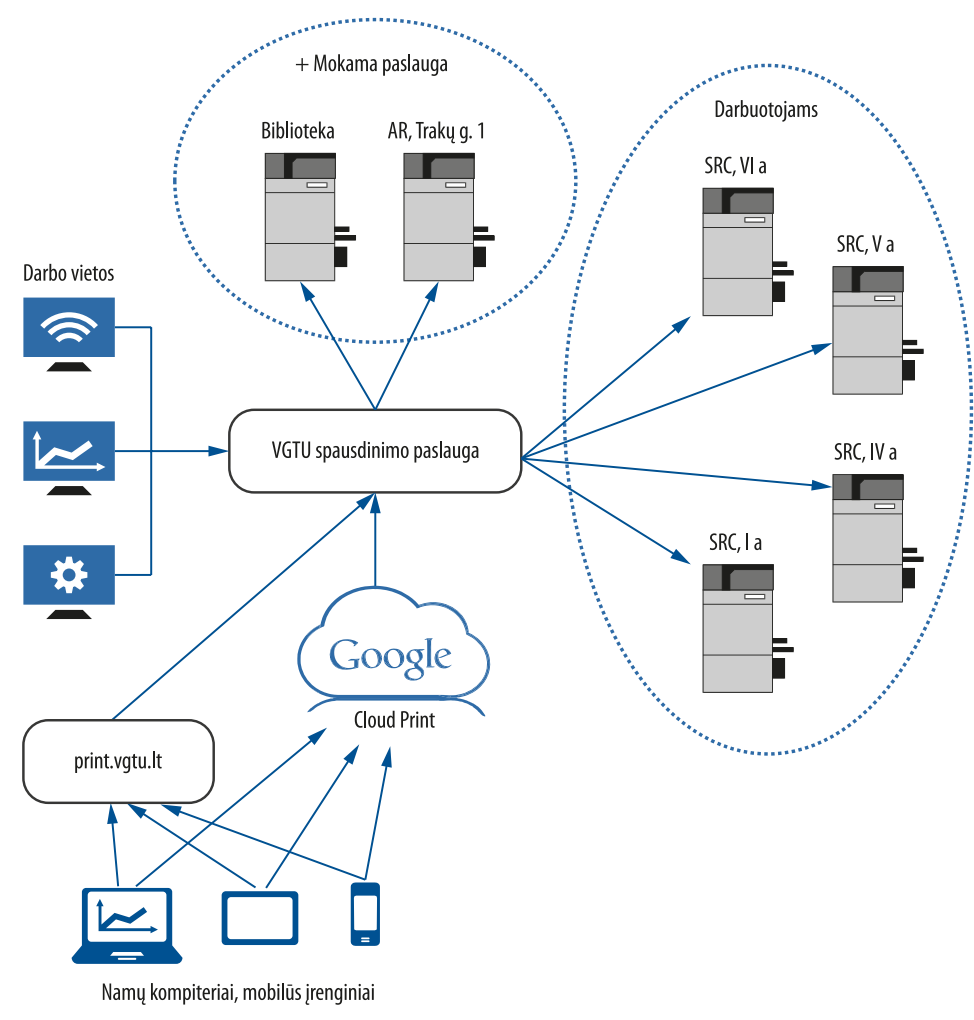

6.35 pav. Centralizuotos spausdinimo paslaugos schema

6.14 lentelè. Bendrieji IT rodikliai

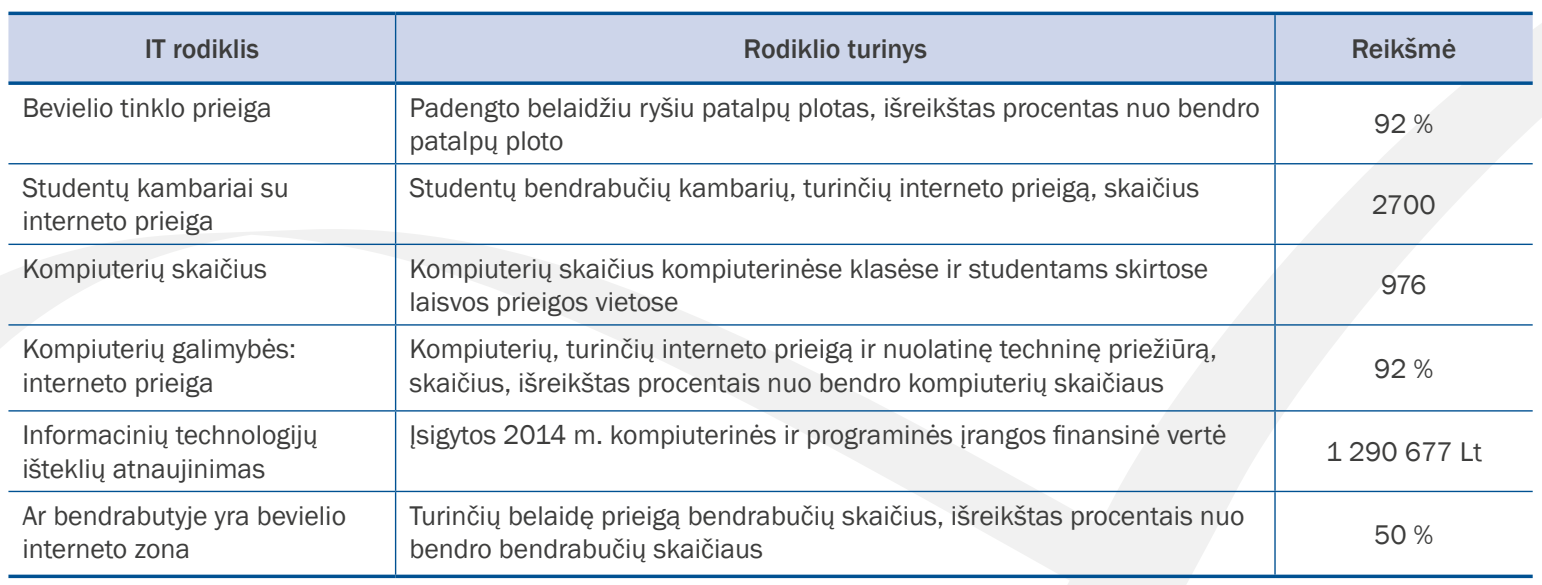


Informacinės technologijos yra pagalbinis visų universitete vykstančių veiklų procesas, darantis įtaką kasdienio darbo greičiui, kokybei ir užtikrinantis tęstinumą. Siekiant minètų procesų nepertraukiamumo, 2015 m. ITSC toliau tobulins IT paslaugų kokybę ir kryptingai vystys numatytus ir naujus IT veiklos projektus.

\section{Studentų bendrabučiai}

Vilniaus Gedimino technikos universitetas eksploatuoja šešis studentų bendrabučius: vienas bendrabutis skirtas AGAI studentams, penki studentų bendrabučiai issikūrę Saulètekyje, iš kurių vienas skirtas studentams, atvykstantiems iš užsienio pagal ivairias mainu programas. Ataskaitiniu laikotarpiu faktinis vidutinis metinis užimtumas pagal bendrabučius svyravo nuo 80,38 \% iki 90,60 \%, o bendras faktinis vidutinis metinis užimtumas, ivertinus vasaros laikotarpi, siekè 88,05 \% (6.36 pav.).

Visi studentų bendrabučiai išlaikomi iš mokesčių, surinktų iš gyventojų už gyvenimą juose. 2014 m. studentų bendrabučiai iš viso patyrẻ 3767,7 tūkst. Lt išlaidų, iskaitant administravimo, paslaugų ir remonto darbu išlaidas, kurių didžiausią lyginamają dalị iš visų išlaidų sudarè šildymo išlaidos (6.37 pav.).

Lyginant VGTU eksploatuojamų bendrabučių 2014 m. faktines pagrindinių komunalinių paslaugu išlaidas šildymui, elektros energijai, vandens ištekliams ir dujoms su $2013 \mathrm{~m}$. patirtomis atitinkamomis išlaidomis (6.15 lentelè), matyti, kad 18 \% sumažèjo išlaidos šildymui, 5,3 \% - elektros energijai, 5,4 \% - dujoms, bet $22,2 \%$ padidejo išlaidos vandeniui.

Bendrabučių gyventojų issiskolinimas už suteiktas paslaugas 2014 m. svyravo nuo 2,2 \% iki 4,5 \% nuo įmokų, priskaitytų per metus.
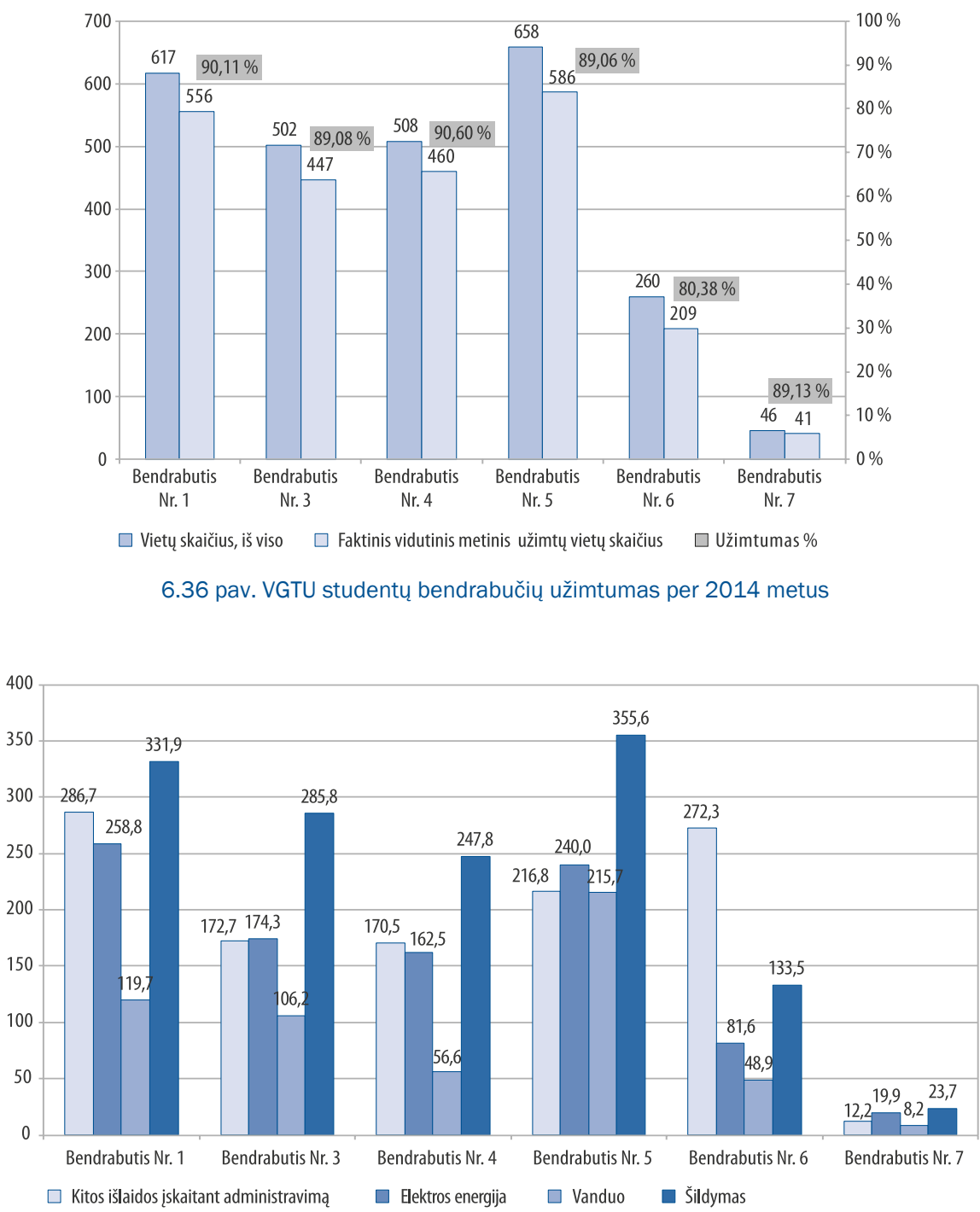

6.37 pav. VGTU studentų bendrabučiu komunalinių paslaugu išlaidų struktūra 2014 m. 
6.15 lentelè. VGTU studentų bendrabučių 2013-2014 m. komunalinių paslaugu faktinių išlaidų (su PVM) santykinis palyginimas

\begin{tabular}{|c|c|c|c|c|c|c|c|c|c|c|c|c|c|}
\hline \multirow[b]{2}{*}{$\begin{array}{l}\text { Eil. } \\
\text { Nr. }\end{array}$} & \multirow[b]{2}{*}{ Bendrabutis } & \multicolumn{3}{|c|}{ Šildymas } & \multicolumn{3}{|c|}{ Elektros energija } & \multicolumn{3}{|c|}{ Vanduo } & \multicolumn{3}{|c|}{ Dujos } \\
\hline & & 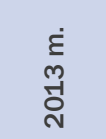 & $\begin{array}{l}\dot{E} \\
\dot{+} \\
\text { ¿े }\end{array}$ & 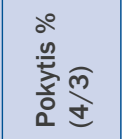 & $\begin{array}{l}\dot{\varepsilon} \\
\text { m. } \\
\text { ने }\end{array}$ & 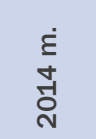 & 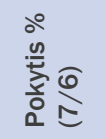 & 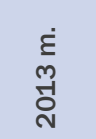 & 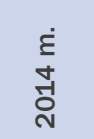 & 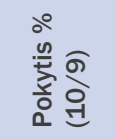 & $\begin{array}{l}\text { ह் } \\
\text { กે } \\
\text { ํํ }\end{array}$ & 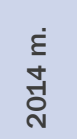 & 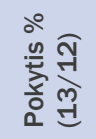 \\
\hline 1. & $\begin{array}{l}\text { Bendrabutis } \\
\text { Nr. } 1\end{array}$ & 480,3 & 331,9 & $-30,9 \%$ & 260,5 & 258,8 & $-0,7 \%$ & 116,9 & 119,7 & $2,4 \%$ & & & \\
\hline 2. & $\begin{array}{l}\text { Bendrabutis } \\
\text { Nr. } 3\end{array}$ & 310,7 & 285,8 & $-8,0 \%$ & 187,2 & 174,3 & $-6,9 \%$ & 77,3 & 106,2 & $37,4 \%$ & 8,0 & 7,7 & $-3,8 \%$ \\
\hline 3. & $\begin{array}{l}\text { Bendrabutis } \\
\text { Nr. } 4\end{array}$ & 297,4 & 247,8 & $-16,7 \%$ & 171,4 & 162,5 & $-5,2 \%$ & 53,5 & 56,5 & $5,6 \%$ & 8,8 & 8,2 & $-6,8 \%$ \\
\hline 4. & $\begin{array}{l}\text { Bendrabutis } \\
\text { Nr. } 5\end{array}$ & 409,4 & 355,6 & $-13,1 \%$ & 266,4 & 240,0 & $-9,9 \%$ & 151,3 & 215,7 & $42,6 \%$ & & & \\
\hline 5. & $\begin{array}{l}\text { Bendrabutis } \\
\text { Nr. } 6\end{array}$ & 156,5 & 133,5 & $-14,7 \%$ & 89,2 & 81,7 & $-8,4 \%$ & 44,7 & 48,9 & $9,4 \%$ & & & \\
\hline 6. & $\begin{array}{l}\text { Bendrabutis } \\
\text { Nr. } 7\end{array}$ & 25,6 & 23,7 & $-7,4 \%$ & 14,7 & 19,9 & $35,4 \%$ & 10,6 & 8,2 & $-22,6 \%$ & & & \\
\hline & Iš viso & 1679,9 & 1378,3 & $-18,0 \%$ & 989,4 & 937,2 & $-5,3 \%$ & 454,3 & 555,2 & $22,2 \%$ & 16,8 & 15,9 & $-5,4 \%$ \\
\hline
\end{tabular}

Bendrabučių reikmėms skiriamas nuolatinis dėmesys. Pagal esamas galimybes vyksta remonto darbai, aprūpinimas reikiama įranga, inventoriumi ir baldais. 2014 m. studentų bendrabučių Nr. 1, 3, 4, 5 gyventojų reikmėms buvo nupirkta baldų, buitinės technikos ir laisvalaikio zonoms skirto inventoriaus už 112,8 tūkst. Lt. 2014 m. studentų bendrabutyje Nr. 1 buvo įrengta vienuolika virtuvių, jose sumontuota nauja buitinè technika. Bendrabutyje Nr. 6 buvo atliktas septynių kambarių ir jiems priklausančių bendrojo naudojimo patalpu remontas, nupirkti baldai, sumontuota nauja buitinè technika. Šiuose kambariuose bus galima apgyvendinti keturiolika studentų iš užsienio. 2014 m. ketvirtaji ketvirti pradèti šio bendrabučio atnaujinimo (modernizavimo) darbai.

Kituose bendrabučiuose atlikti mažesnès apimties remonto darbai. Bendrabučiuose Nr. 1 ir Nr. 5 įdiegtas ir pradėjo veikti bevielis internetas. Bendrabučių Nr. 1, 3, 4 ir 5 gyventojams įrengtos dvi dviračių saugyklos, kuriose gyventojai gali laikyti apie 50 dviračių.

Bendrabučiams ir jų infrastruktūrai kompleksiškai pagerinti reikalingas papildomas išorinis finansavimas. VGTU dalyvauja Švietimo ir mokslo ministerijos parengtoje Aukštuju mokyklų ir profesinio mokymo istaigu bendrabučių atnaujinimo (modernizavimo) programoje, finansuojamoje JESSICA iniciatyvos lèšomis. 2012 m. kovo 22 d. Lietuvos Respublikos švietimo ir mokslo ministro isakymu Nr. V-525 patvirtintas minètos programos planuojamu atnaujinti (modernizuoti) bendrabučių sąrašas, pagal kuri VGTU 2012-2015 m. igyvendina penkių bendrabučių energinių savybių pagerinimo priemones apšiltinant sienas ir stogus, rūsių perdangas, atnaujinant šildymo sistemas ir dali elektros instaliacijos - numatomas preliminarus skolintu lèšų poreikis siekia 13,3 $\mathrm{mln}$. Lt.

Planuojama, kad po šio atnaujinimo energinių išteklių pastatams šildyti reikès iki 39 \% mažiau nei iki modernizavimo.

VGTU - vienintelis Lietuvos universitetas, perkantis bendrabučių administravimo paslaugas iš specializuotos i̇monès. Nuo 2012 m. sausio 1 d., laimèjusi VGTU skelbtą viešą bendrabučiu administravimo paslaugu pirkimo konkursą, bendrabučius Nr. 1, 3, 4, 5 trejus metus administravo UAB „Economus“. 2014 m. UAB „Economus“ administruojant minètus bendrabučius, periodiškai kilo problemų, susijusių su bendrabučių patalpų ir teritorijos valymo kokybe (už netinkamą valymo kokybę buvo surašyta vienuolika aktų), uždelstu užfiksuotų ỉrangos, irenginių, komunikacinių ir inžinierinių tinklų bei inventoriaus defektų šalinimu.

Lyginant su 2013 m. su ataskaitiniais metais, gyventojų saugumas ir drausmė pamažu gerėjo. Už bendrabučių vidaus taisyklių pažeidimus 2013 m. iš gyventoju buvo paimti 363, o 2014 m. - 156 pasiaiškinimai. 2014 m. apie 30 proc. sumažėjo dèl piktybiško gyventojų elgesio padaryta materialinè žala bendrabučiams.

2014 m. už netinkamą finansinių issipareigojimų vykdymą iš VGTU studentų bendrabučių buvo pašalinti aštuoni, o už elgesị, pažeidžiantị VGTU bendrabučių vidaus tvarkos taisykles, keturiolika ivairių fakultetu studentų.

Didelę reikšmę bendrabučių administravimo paslaugu gerinimui turi aktyvi VGTU studentu atstovybės ir atskiru jos narių pozicija ịvairiais svarbiais studentų bendrabučių gyventoju gyvenimo klausimais. Baigiamas 
igyvendinti VGTU studentų atstovybės pasiūlymas įdiegti bendrabučio Tarybos modeli, kuri igyvendinus bendrabučių aukštų seniūnai būtų atsakingi už aukšte gyvenančių gyventojų drausmę, vidinę kultūrą ir pagerintų tvarką bendrabučiuose. Ataskaitiniu laikotarpiu, lyginant su 2013 m., VGTU administracijos ir Studentu atstovybès pastangomis bendrabučių administravimo problemos buvo sprendžiamos sklandžiau.

2014 m., baigiantis minètu konkursu sudarytai bendrabučių administravimo paslaugu teikimo sutarčiai, VGTU nusprendè toliau pirkti bendrabučių administravimo paslaugas iš rinkoje teikiančiu tokias specializuotas paslaugas imonių. Tuo tikslu buvo parengtos naujos šių paslaugu pirkimo konkurso sąlygos, kuriose, siekiant pagerinti teikiamų paslaugu kokybę bendrabučiu gyventojams, buvo numatyta kiekviename bendrabutyje isteigti ištisą parą funkcionuojančius budėtojų postus, sugriežtinti teikiamų valymo paslaugu kontrolès priemones, interneto teikimo bei įrangos ir tinklų priežiūros bei techninės priežiūros paslaugos perduoti VGTU Informacinių technologiju sistemų centrui, patobulinta ir nustatyta efektyvesnè bendrabučiu gyventojų isiskolinimų už suteiktas paslaugas valdymo tvarka.

Nuo 2015 m. sausio 1 d. minètus keturis studentų bendrabučius trejus metus administruos, atvirą viešą konkursą laimèjusi UAB „Economus“, veikianti jungtinès veiklos pagrindu su UAB „Corpus A“.

VGTU ir ateityje yra pasirengęs skirti daugiau dėmesio ir pastangų studentų bendrabučius administruojančios įmonės veiklos priežiūrai, atsižvelgiant i finansines galimybes, gerinti studentų gyvenimo sąlygas, plèsti teikiamas paslaugas, didinti bendrabučių vietų užimtumą, vykdyti pastatų atnaujinimą.

\section{ES struktūrinè parama}

2014-ieji yra pirmieji naujojo 2014-2020 m. Europos Sajungos struktūrinių fondų (toliau - ES SF) finansavimo periodo metai. Šiais metais buvo patvirtinti pagrindiniai ES SF lèšu paskirstymą reglamentuojantys strateginiai dokumentai - Partnerystès sutartis bei 2014-2020 metu Europos Sajungos fondu investiciju veiksmų programa. Šiuose dokumentuose numatyta dvylika prioritetų, iš kurių VGTU svarbiausi yra du - moksliniu tyrimų, eksperimentinès plètros ir inovaciju skatinimas; visuomenės švietimas ir žmogiškujų išteklių potencialo didinimas. Aktyvus VGTU dalyvavimas, siekiant 2014-2020 m. finansavimo periodo paramos, yra viena iš sėkmės prielaidų, leisiančių pasiekti 2014-2020 m. VGTU plètros strategijoje iškeltus ambicingus studijų, mokslinių tyrimų ir eksperimentinès plètros, inovacijų skatinimo, infrastruktūros plètros bei valdymo tobulinimo tikslus ir uždavinius, tačiau 2014 m. nebuvo paskelbta nė vieno naujojo ES SF finansavimo periodo kvietimo, kuriame galètų dalyvauti VGTU, todèl pagrindinis dėmesys nukreiptas i sėkmingą 2007-2013 m. periodo projektų igyvendinimą ir užbaigimą bei efektyvu pasirengimą naujajam 2014-2020 m. periodui.

Pasibaigus 2007-2013 m. periodui ir dar neįsibègejjus 2014-2020 m. finansavimo periodui, 2014 m. nauju projekto finansavimo ir administravimo sutarčių nebuvo pasirašyta. Iš visu 2007-2013 m. periodo 35 projektu (finansavimo pasiskirstymas pagal investavimo kryptis pateikiamas 6.38 pav.) buvo tęsiamas 21-o anksčiau pradėto vykdyti projekto igyvendinimas. Bendra vykdytu projektų vertė - 15351 tūkst. Eur.

Pagrindinės 2014 m. vykdytų projektu grupės yra: mokslinių tyrimų ir tyrèju gebejjimų stiprinimo projektai (dešimt projektų), studijų kokybės gerinimo ir tarptautiškumo didinimo projektai (šeši projektai), infrastruktūros plètros projektai (keturi projektai), kokybės vadybos sistemos projektas.

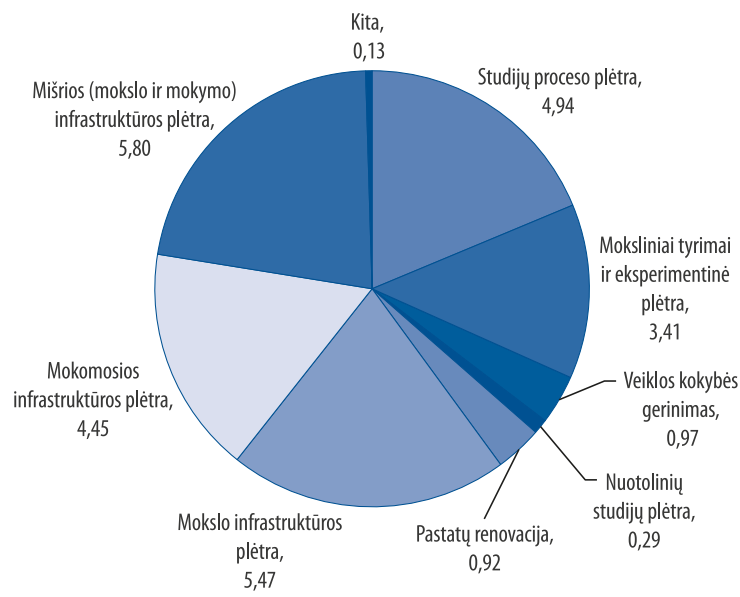

6.38 pav. VGTU vykdomu struktūrinių fondu projektų finansavimo pasiskirstymas pagal investavimo kryptis 2007-2013 m., mln. Eur

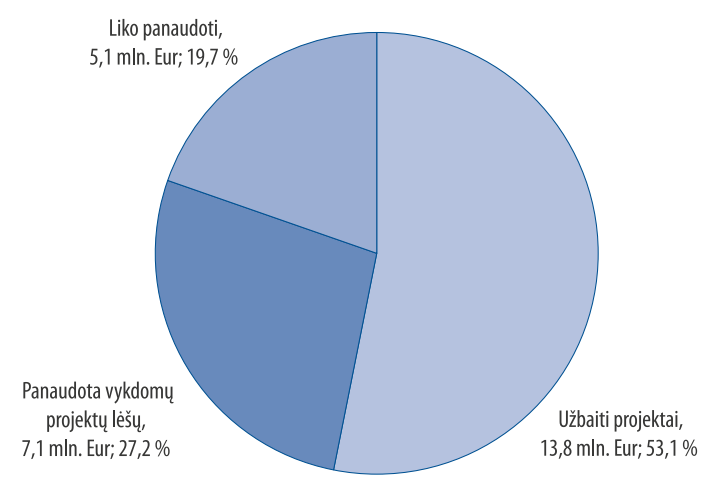

6.39 pav. Struktūrinių fondų paramos projektų vykdymo pažanga 
Iš dešimties vykdytų mokslinių tyrimų ir tyrejjų gebejjimų stiprinimo projektų net devyni buvo aukšto tarptautinio lygio moksliniai tyrimai, vienas buvo skirtas Lietuvos statybų technologinei platformai stiprinti. Džiugu, kad 2014 m. buvo užbaigtas pirmojo pasibaigusio mokslinio tyrimo projekto MTEP (MTTP) igyvendinimo ataskaitos ekspertinis vertinimas ir gauta teigiama vertinimo išvada.

Vykdant studijų projektus, buvo užbaigti nuotolinių studijų plètros ir studijų programų atnaujinimo bei specialistų rengimo mokslui imliems ūkio subsektoriams projektai, parengtos ir pradètos igyvendinti dvi naujos jungtinès studijų programos.

Vykdant infrastruktūros plètros projektus baigiamas vykdyti VGTU Mokslo ir administracijos centro statybos I etapas - Transporto ir civilinės inžinerijos mokslo ir studiju korpuso statyba; užbaigtas projektuoti ir pradètas rekonstruoti Antano Gustaičio aviacijos instituto Treniruoklių ir laboratoriju korpusas bei VGTU ir Edinburgo Neipiero universitetų produktų dizaino, inovacijų ir kūrybinių industrijų centro „LINK MENŲ fabrikas“ pastato kapitalinis remontas; isibėgejjo Elektronikos, Mechanikos ir Transporto inžinerijos fakultetų laboratoriju korpuso, Elektronikos fakulteto mokomojo korpuso bei Mechanikos ir Transporto inžinerijos fakultetų mokomojo korpuso projektavimas Saulètekio studentų miestelyje.

2014 m. iš dvidešimt vieno vykdyto projekto buvo užbaigtos igyvendinti penkių projektų veiklos. Visų VGTU vykdytų 2007-2013 m. periodo ES SF projektų lèšų panaudota daigiau kaip 80 proc., vien užbaigtų projektų gauta finansavimo suma sudaro daugiau nei 53 proc. visų VGTU projektų finansavimo (6.39 pav.). 



\section{Visuomeniškumas}
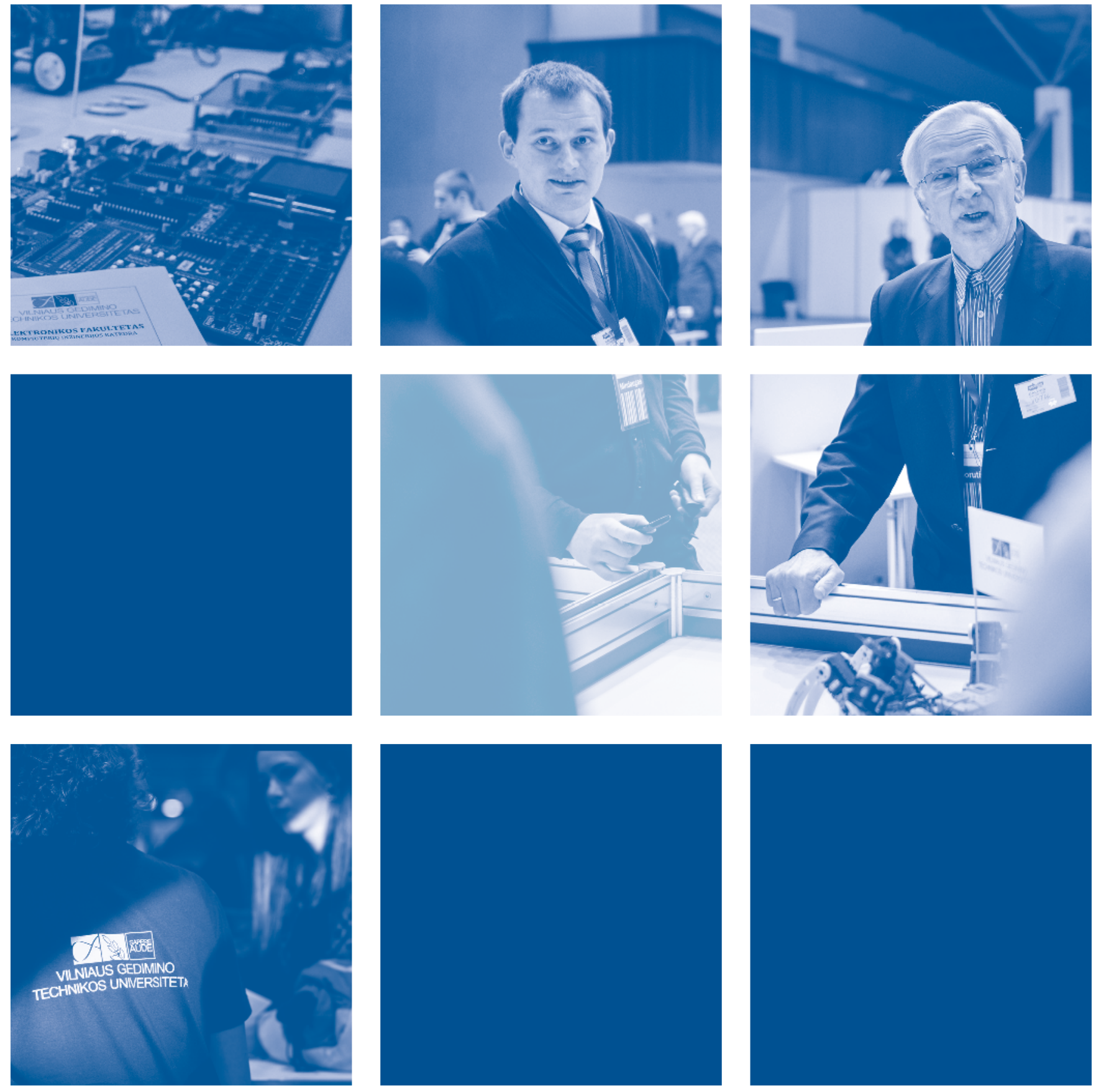



\section{Visuomeniškumas}

\section{Universitetas viešojoje erdvèje}

Vilniaus Gedimino technikos universitetas savo veikloje remiasi atvirumo ir skaidrumo vertybėmis, tad informacija apie VGTU vykdomą veiklą yra vieša ir laisvai prieinama visuomenei.

Viena iš priemonių šiam tikslui pasiekti - universiteto interneto svetainè, kurioje lietuvių ir anglų kalbomis skelbiama naujausia su VGTU veikla susijusi informacija. 2014 m. lapkričio mèn. pradejjo veikti nauja moderni www.vgtu.It svetainè, kurioje išryškintas universiteto identitetas ir pagal tikslinių auditoriju poreikius atnaujinta struktūra. Funkcionali struktūra leido sutrumpinti vartotojui kelią, ieškant reikalingos informacijos.

Praèjusiais metais universiteto svetainę aplankẻ daugiau nei 560 tūkst. žmonių, kurie peržiūrèjo 7 mln. puslapių. Bendras unikalių lankytojų skaičius, palyginti su 2013 m., kai universiteto svetainę aplankè 500 tūkst. žmonių, sumažèjo 6 proc.

Antraštiniame www.vgtu.It puslapyje pateikiama naujienų skiltis, kurioje kasdien skelbiamos žinutės, supažindina svetainės lankytojus su universiteto gyvenimu. 2014 m. interneto svetainèje buvo publikuota 360 naujienų ir tai yra 60 proc. daugiau nei 2013 m. Naujienų daugejja antrus metus iš eilès. 2014 m., palyginti su 2013 m., naujienų padaugèjo 60 proc. (7.1 pav.).

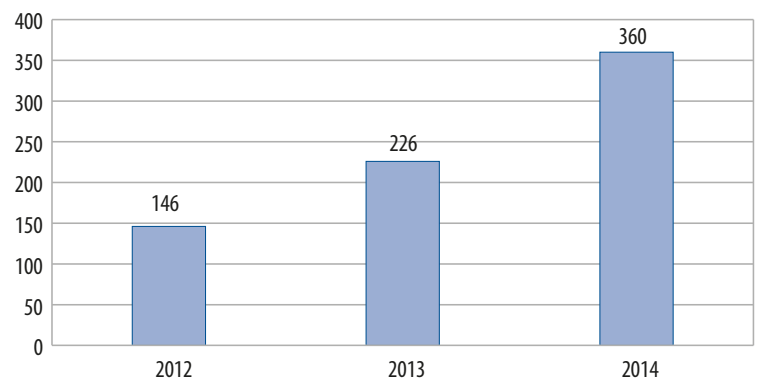

7.1 pav. Naujienų, publikuotų vgtu.It, skaičius

Praejjusiais metais VGTU išleido tris žurnalo „Sapere Aude“ numerius. $2014 \mathrm{~m}$. buvo atnaujinta šio žurnalo koncepcija, apimanti „Sapere Aude“ ir anksčiau leisto žurnalo „Gedimino universitetas“ gerają praktiką. Atnaujintame „Sapere Aude“ žurnale išsiplètè turinys, atsirado didesnè temų ir žanrų ìvairovè. Žurnalo apimtis padidèjo beveik trečdaliu, o tiražas, siekiant padidinti skaitytojų ratą, išaugo nuo 500 iki 800 egz. Leidiniai platinami ne tik universitete, bet ir už jo ribų - jie patenka i Lietuvos bibliotekas, valstybines ir verslo institucijas. Visus žurnalo numerius taip pat galima skaityti elektroninèje erdvèje.

Žurnalas „Sapere Aude“ atlieka reprezentacinę funkciją ir pristato geriausius universiteto veiklos aspektus, mokslo naujoves ir i̇domybes, perteikia žinias siekiant ugdyti kūrybingą ir kritišką mąstymą. Savo patirtimi ir ¡žvalgomis dalijasi kalbinami absolventai, studentai, mokslininkai, kiti bendruomenès nariai ar universiteto svečiai.

VGTU vykdo švietėjišką ir mokslo populiarinimo misiją. Aktyviai bendradarbiaudamas su žiniasklaida, universitetas supažindina visuomenę su mokslo pasiekimais, studentų sėkmės istorijomis, studiju teikiamomis perspektyvomis, kitais svarbiais aukštojo mokslo ịvkiais, pateikia komentarus apie visuomenei svarbias aktualijas.

Komunikacijos kanalai apima visus žiniasklaidos tipus: naujienų portalus, tarp kurių populiariausi delfi.lt, 15min.It, Irytas.It, nacionalinius ir regioninius dienraščius („Lietuvos rytas“, „Lietuvos žinios“, „Vakarų ekspresas“ ir kiti), specializuotą periodinę spaudą („Verslo žinios“, „Veidas“ ir kiti), radijo ir televizijos kanalus.

2014 m. VGTU išplatino 69 pranešimus žiniasklaidai (7.2 pav.) ir tai yra penktadaliu daugiau nei 2013 m., kai buvo išplatinti 55 pranešimai. Praejjusiais metais išaugo ne tik platinamų pranešimų skaičius, bet ir šių žinučių matomumas žiniasklaidoje. Pranešimais pasiektos auditorijos dydis išaugo kelis kartus. Taip pat $2014 \mathrm{~m}$. žiniasklaidoje daugèjo straipsnių, kuriuose buvo kalbinami VGTU ekspertai ar pristatomi mokslininkų ir studentų pasiekimai. 


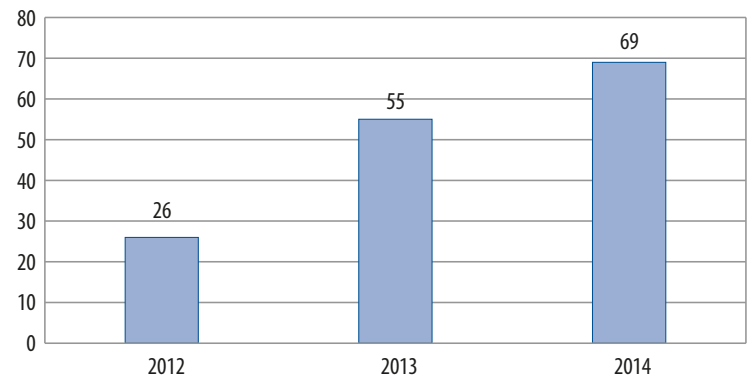

7.2 pav. Pranešimų žiniasklaidai skaičius

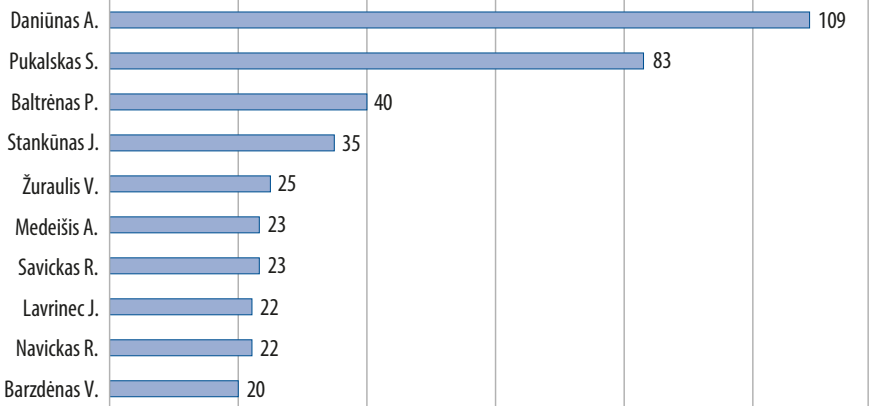

7.3 pav. Dešimt bendruomenès narių, labiausiai cituotu žiniasklaidoje $2014 \mathrm{~m}$.

2014 m. didžiausią skaitytojų auditoriją pasiekè VGTU dalyvavimas festivalyje „Erdvèlaivis Žemė“. Viešosios komunikacijos direkcijos iniciatyva VGTU pirmą kartą dalyvavo šiame festivalyje. Universitetas organizavo tik VGTU skirtą Mokslo atradimu dieną, kurioje dalyvavo Lietuvos Respublikos Prezidente Dalia Grybauskaitè. Šventinio atidarymo metu pirmą kartą Lietuvoje tradicinę juostelès kirpimo ceremoniją atliko robotas. VGTU vykusi Mokslo atradimų diena buvo paminèta ịvairiuose žiniasklaidos kanaluose 29 kartus, 4 iš ju - televizijos laidose TV3, LRT ir Pirmajame Baltijos kanale. Internetiniuose žiniasklaidos portaluose buvo paminèta 25 kartus, iš kurių 4 - populiariausiame portale www.delfi.lt.

Kitas renginys, sulaukęs daugiausia viešumo, buvo Karjeros dienos. Apie ši rengini žiniasklaidoje buvo rašyta 27 kartus interneto portaluose (daugiau nei trečdalis paminėjimų buvo penkiuose populiariausiuose portaluose), spaudoje ir radijo laidose.

Trys matomiausi universiteto atstovai, kuriuos daugiausia kartų $2014 \mathrm{~m}$. citavo žiniasklaida, yra VGTU rektorius prof. dr. A. Daniūnas, Transporto inžinerijos fakulteto (TIF) Automobilių transporto katedros vedèjas doc. dr. S. Pukalskas, Aplinkos inžinerijos fakulteto (APF) Aplinkos apsaugos katedros prof. habil. dr. P. Baltrènas (7.3 pav.).

Cituotu atstovu kompetenciju sritys atspindi universiteto veiklos sričiu ịvairovę - nuo aplinkos apsaugos, eismo saugumo, kompiuterių inžinerijos, išmaniosios elektronikos, aviacijos iki ateities miestų ir kitų temu. Palyginti su 2013 m. labiausiai cituotų ekspertų sritimis, praejjusiais metais temų ratas gerokai prasiplètè. Tai iliustruoja VGTU tikslus dalytis žiniomis ir ižvalgomis su visuomene tose srityse, kuriose universitetas yra sukaupęs didžiausią patirti. VGTU rektorius prof. dr. Alfonsas Daniūnas ir doc. dr. Saugirdas Pukalskas pateko ir tarp 15 labiausiai cituotų visų Lietuvos aukštujų mokyklų atstovų.

Komunikaciją žiniasklaidoje teigiamai vertina išoriniai žiniasklaidos analitikai. Ju duomenimis, informacijos apie VGTU palankumas žiniasklaidoje 2014 m. kaip ir 2013 m. buvo geriausias iš penkių didžiausių valstybiniu Lietuvos universitetu.

Komunikacija socialiniuose tinkluose. Universitetas aktyviai išnaudoja komunikacijos galimybes socialiniuose tinkluose. Šių tinklaviečių svarba nuolat auga užmezgant ir stiprinant santykius su tikslinėmis auditorijomis, tad praejjusiais metais VGTU tęsè komunikaciją socialinio tinklo „Facebook“ svetainèje, taip pat atnaujino paskyras „Linkedln“ ir „Twitter“ tinklavietėse, sukūrè oficialų profili socialinèje svetainèje „Instagram“.

Aktyviausiai universitetas išnaudoja VGTU „Facebook“ paskyrą, kuri pasiekia potencialius, esamus ir buvusius studentus. Pagrindinè VGTU paskyra per 2014 m. sulaukè beveik 5000 nauju gerbejjų. Paskutinę metų dieną ši paskyra turèjo kiek daugiau nei 17000 gerbèjų ir tai yra 40 proc. daugiau nei prieš metus. Palyginimui - 2013 m. gerbèjų padaugejo 20 proc. 2014 m. viena žinutè pasiekdavo vidutiniškai 6500 skaitytojų. Šioje paskyroje pateikiama informacija apie VGTU renginius, naujienas, skelbiami žaidimai, konkursai, nuotraukos iš universiteto gyvenimo.

2014 m. VGTU socialiniame tinkle „Facebook“ sukūrè naują paskyrą „Moksliukai“, kuri per mažiau nei metus sulaukẻ beveik 4400 gerbejjų. Šioje paskyroje VGTU vykdo įvairius žaidimus, skelbia moksleiviams aktualią informaciją apie universitete vykstančias atvirų dienų dienas, studijų parodas, mokslo pasaulio faktus ir i̊domybes.

VGTU vykdo kryptingą komunikaciją viešojoje erdvejje, kuri apima www.vgtu.It svetainę, universiteto leidžiamą periodiką, socialinius tinklus. Komunikacija pritaikyta skirtingoms auditorijoms ir kanalams, tačiau ji atspindi universiteto vertybes - tarptautiškumą, bendruomeniškumą, tarpdalykiškumą, bendradarbiavimą, kūrybingumo ir inovaciju skatinimą. 


\section{Alumnai}

VGTU siekia sukurti vieningą ir stiprią bendruomenę, todėl viena iš iniciatyvų - VGTU absolventu skatinimas palaikyti ryši su universitetu tampant Absolventų ir bičiulių klubo nariu, kurio veikla prasidèjo prieš dešimtmeti.

- 2014 m. vasario 26 d. ivyko VGTU Absolventų ir bičiulių klubo valdybos posėdis, kurio metu buvo parengti ir patvirtinti VGTU fakultetinių absolventų klubų nuostatai.

- 2014 m. gegužès 20 d. j̇vko visuotinis narių susirinkimas. Jo metu buvo pristatyta trumpa veiklos/finansinè ataskaita ir numatytos tolimesnès VGTU Absolventų ir bičiulių klubo veiklos gairès.

- 2014 m. lapkričio mèn. vyko Integracijos ir karjeros direkcijos darbuotojų, atsakingu už VGTU alumnų veiklų koordinavimą, susitikimai su fakultetinių klubų koordinatoriais. Jų metu buvo aptarta vykdoma veikla, planai ir lūkesčiai. Buvo nutarta, kad kiekvienas klubas fakultetuose turi surengti fakultetinio skyriaus susirinkimą ir išsirinkti delegatus i valdybos posèdi.

- 2014 m. gruodžio mèn. parengtas kasmetis „Naujienlaiškis“ absolventams, sumaketuotos ir išspausdintos informacinės skrajutès su kvietimu jungtis prie VGTU Absolventų ir bičiulių klubo, kuriose patogiai išdèstyta informacija apie Klubo teikiamas naudas ir apie tai, kaip prisijungti ir tapti Klubo nariu.

- 2014 m. gruodžio mèn. baigti internetinio VGTU alumnų puslapio prototipo kūrimo techniniai darbai, prototipas perduotas dizaino specialistams. Šiuos darbus padeda koordinuoti Informacinių technologijų ir sistemų centras.

Nuo 2012 m. rugsèjo mènesio iki 2014 m. pabaigos universitete veikè VGTU absolventų duomenų bazè, kurioje yra 1932 prisiregistravę absolventai, šiuo metu duomenys naujame vgtu.lt puslapyje kaupiami absolventams užpildžius internetinę registracijos anketą.

\section{Meno kolektyvai}

2014 m. meno kolektyvai toliau stengèsi garsinti savo Alma Mater vardą ivairiuose Lietuvos miestuose bei užsienyje. Universiteto studentai turẻjo galimybę dalyvauti mėgstamoje veikloje, tobulinti savo igūdžius ir turiningai leisti laisvalaikị. Universiteto meno kolektyvuose dalyvavo 252 nariai.

VGTU choras „Gabija“ per metus surengęs net 33 koncertus ivvairiuose Lietuvos miestuose ir kitose šalyse. Dalyvavo VGTU renginiuose, puoselejo bendrystę tarp choristų ir kitu chorų.

Vienas svarbiausių ivykių chorui tapo 50-ies metų jubiliejinis koncertas, vykęs Lietuvos nacionalinèje filharmonijoje. Šventėje pasirodè net keturi chorai - VGTU akademinis choras „Gabija“, "Gabijos“ alumnu choras, gabijiečių vaikučių ir jungtinis choras. Drauge su choristais pasirodè ir puikūs džiazo virtuozai iš Klaipėdos: Saulius Šiaučiulis (klavišiniai), Laimonas Urbikas (saksofonai) ir Viktoras Rubežas (mušamieji). Vidurnakti šventès dalyviai Katedros aikštèje dainomis palydejjo ị dangų 50 dangaus žibintų, mintyse linkèdami chorui „Gabija“ dar ilgai gyvuoti! 0 iš vakaro choras pasireklamavo LTV laidoje „Labas rytas“.

Spalio mėnesi Serbijoje vykusiame tarptautiniame chorų konkurse ir festivalyje „Vrnjačka Banja 2014“ pasiektas rezultatas džiuginantis: „Gabija“ parsivežè auksą, komisija taip pat apdovanojo Rasą Viskantaitę diplomu už išskirtini, menišką pasirodymą. Choro vadovė pripažinta geriausia choro dirigente iš visų dalyvavusių serbų, slovènų, rumunų ir švedų dirigentų. Birželio 27-29 d. choras kartu su kitų universitetų choristais, šokẻjais, muzikantais iš triju šalių dalyvavo XVII Baltijos šalių studentų dainų ir šokių šventẻje „Gaudeamus“ Daugpilyje.

"Gabija“ su kitais chorais iš visos Lietuvos dalyvavo Lietuvos dainų šventèje „Čia - mano namai“. Vingio parko estradoje aidejjo gražiausi visų laikų kūriniai chorams - nuo klasikinių iki modernių harmonijų ir šiuolaikinių ritmų; senosios liaudies dainos, harmonizuotos pagal Vakarų Europos klasikinès harmonijos kanonus, kūriniai a cappella - visa, kas neatsiejama nuo Dainų dienos ištakų. Tūkstantiniam chorui dirigavo ir choro meno vadovè Rasa Viskantaitè. Sausio 26 d. choras giedojo Lietuvos kariuomenès Šv. Ignoto bažnyčioje. Buvo užpirktos Šv. Mišios už buvusi meno vadovą Feliksą Viskantą ir paminėtos jo 80-osios gimimo metinės. Kovo 1 d. VGTU choras „Gabija“ koncertavo Palaimintojo Jurgio Matulaičio bažnyčioje. Choras savo dainomis pradejjo koncertini ciklą „Sakralinės muzikos valandos Vilniaus Pal. Jurgio Matulaičio bažnyčioje“. „Gabija“ koncertavo Vilniaus senamiestyje šurmuliavusioje Kaziuko mugeje ir prie Vilniaus rotušès šildè mugės lankytojus nuotaikingais kūriniais.

Lietuvos valstybės atkūrimo dienos minėjimo išvakares choras sutiko palaikydamas Ukrainos kovotojus už laisvę. Užupio Respublikos Konstitucijos ukrainiečių kalba lentos atidengimo renginyje dainavo ukrainietiškai. Savo paramą Ukrainai choras išreiškè ir dalyvaudamas Labdaros koncerte nukentėjusiems Maidane paremti „Už jūsų ir mūsų balsą. Lietuvos menininkai - Ukrainai“ Šv. Kotrynos bažnyčioje, kuris tiesiogiai buvo transliuojamas per LTV Kultūros kanalą ir i Ukrainą (Maidaną). 
Kovo 10-ają choras koncertavo Lietuvos nepriklausomybės atkūrimo dienos minèjimo renginyje „Kas mums yra laisvè?“ universiteto bendruomenei VGTU Saulètekio rūmuose.

Gražų pavasari „Gabija“ pasitiko soliniu koncertu Taikomosios dailès muziejuje. Choras koncertavo Vilniaus Žirmūnų gimnazijos renginyje „Naktis mokykloje“ ir susilaukè ypatingo mokinių dèmesio bei gausių aplodismentų.

Dalyvauta XV tarptautiniame sakralinės muzikos festivalyje „Džiūgaukim... Aleliuja, 2014“ Marijampolèje. Šv. Mišių metu ir po jụ choras koncertavo Šv. Vincento Pauliečio bažnyčioje, vèliau Marijampolès kolegijos Edukologijos fakulteto iškilmių salejje kartu su LEU choru „Ave Vita“.

Gegužès 12-ają choras kūriniais pasveikino buvusi VGTU rektorių Edmundą Kazimierą Zavadską gražios 70 metu sukakties proga.

Dalyvauta bent keliuose projektuose. Energetikos ir technikos muziejaus Turbinu salèje vyko tarptautinis projektas „MUTE: muzika ir technika“. Koncerte skambėjo lietuvių ir užsienio autorių kūriniai, inspiruoti akustinių instrumentų skambesio ir papildyti nedidelemis technikos prietaisų intervencijomis, o visa tai sujungé Vilniaus miesto savivaldybès Šv. Kristoforo kamerinis orkestras. Spalio 3 d. „Gabija“, giedodama tarptautini studentų himną „Gaudeamus“, nusifilmavo socialinejje reklamoje, kuri dabar rodoma per ịvairius TV kanalus.

Ne mažiau iškilmingas pasirodymas - liepos $12 \mathrm{~d}$. Daukanto aikštėje vykęs antrajai kadencijai išrinktos Lietuvos Respublikos Prezidentès Dalios Grybauskaitės šventinis inauguracijos koncertas. Jame dainavo garsūs Lietuvos atlikejjai, o pritarè jungtinis Vilniaus kolektyvu choras, kuriame dainavo ir VGTU akademinis choras „Gabija“. Spalio mèn. VGTU akademinis choras „Gabija“ dalyvavo Tuskulènų rimties parko memorialiniame komplekse vykusiame minejjime, kuris buvo skirtas monsinjoro Alfonso Svarinsko 60-osioms kunigystės metinèms paminèti.

Lapkričio 14-16 d. VGTU choras dalyvavo XVI Lietuvos aukštuju mokyklu studentų choru festivalyje, kuris vyko pajūryje. Lapkričio 15 d. „Gabija“ giedojo Palangos Švč. Mergelès Marijos ėmimo i Dangu bažnyčioje Šv. Mišių metu ir po jų. Lapkričio 16 d. Klaipèdos universiteto koncertu salèje vyko baigiamasis festivalio koncertas, kur kartu su jungtiniu choru atliko Giedriaus Kuprevičiaus kantatą mišriam chorui, sopranui ir simfoniniam orkestrui „Pagonių giesmès“.

Gruodžio 5 d. VGTU Architektūros rūmu salėje vyko tradicinė XI choru šventė „Žiemos šviesa“. Dalyvavo Vilniaus universiteto Kauno humanitarinio fakulteto merginu choras „Veni gaudere“, Baltarusijos nacionalinio technikos universiteto choro kapela ir Vilniaus Gedimino technikos universiteto akademinis choras "Gabija“. Belaukdamas Kalèdų akademinis choras „Gabija“ dainavo dar keliuose koncertuose: gruodžio 11-ają - VGTU Erasmus renginyje, o gruodžio $17 \mathrm{~d}$. choras giedojo Betliejaus taikos ugnies ekumeninèse pamaldose Šv. Jonu bažnyčioje.

VGTU tautinių šokių ansamblis „Vingis“ per metus surengè 43 pasirodymus ir koncertus, dalyvavo dviejuose tarptautiniuose festivaliuose. Liepos 22-27 d. dalyvavo tarptautiniame muzikos, meno ir folkloro festivalyje-konkurse „Podlasie octave of cultures 2014”, kuriame tapo laureatais. Vingiečiai koncertavo net šešiuose regiono miesteliuose. Festivalyje dalyvavo kolektyvai iš Lenkijos, Lietuvos, Baltarusijos, Adygejos Respublikos, Gruzijos, Bulgarijos, Japonijos, Makedonijos, Serbijos, Austrijos, Ukrainos, Turkijos, Bosnijos ir Hercegovinos, Rugpjūčio 10-21 d. dalyvauta festivalyje „XXXI Raduno Mediterraneo del Folklore Internazionale“ Petralia Sottana mieste, Sicilijoje.

Sausio 25 d. ansambliečiai dalyvavo Dainų šventès ir tautinio kostiumo pristatyme LITEXPO parodų ir kongresu centre, parodos „Adventur'e“ metu. Vasario $16 \mathrm{~d}$. koncertuota su kitais Vilniaus miesto kolektyvais Lietuvos valstybès atkūrimo dienai paminèti M. K. Čiurlionio menų mokyklos Šokio teatre. Kovo 8 d. koncertuota kasmetinèje Kaziuko mugejje, Rotušès aikštèje. Tradiciškai koncertuota Žemès dienos minėjimo renginyje, kuri organizuoja Aplinkos inžinerijos fakultetas. Kovo 29 d. dalyvauta kapelų festivalyje „Universitas Vilnensis“, kuris vyko Vilniaus universiteto Didžiojoje auloje. Balandžio 26 d. organizuota jubiliejinè 5-oji tarptautinė šokio diena, kurioje dalyvavo net septyni kolektyvai. Gegužès 1 d. koncertuota VGTU Studentu atstovybės 20 metu gimtadienio koncerte, gegužès 25 d. - svečiams iš Hiustono universiteto.

Birželio 26-29 d. „Vingis“ kartu su kitais ansambliais iš Lietuvos, Latvijos ir Estijos dalyvavo Baltijos šaliu studentų dainų šventèje „Gaudeamus XVII“, kuri įvyko Latvijoje, Daugpilio mieste. Liepos 1-6 d. Lietuvos dainu šventejje „Čia mano namai“ ansamblis pasirodè Dainų dienoje, kur koncerto metu demonstravo archeologinių, gentiniu ir tautinių kostiumų kolekcijas. Liepos 3 d. ansamblio kapela koncertavo „Ansamblių vakare“. Mūsų šokejjai „Šokio dienos“ koncertuose atliko pagrindinius vaidmenis. Liepos 28 d. - rugpjūčio 3 d. nekantraudami vingiečiai susirinko ị tradicinę stovyklą Aukštadvaryje. Stovykloje daug repetuojama ir tobulinami igūdžiai, nes savaitgali suvažiavo „Vingio“ alumnai, kuriems ir parodytas koncertas.

Rugsèjo 14 d. ansamblio „Vingis“ šokèjos dalyvavo „Danske bank“ maratono atidarymo ir uždarymo renginiuose. Rugsèjo 18 d. kartu su kitais VGTU meno kolektyvais sukūrè linksmą pasirodymą „Gedimino dienu““ atidaryme, o rugsèjo 20 d. koncertavo Angelų sargu šventėje Ukmergejje. Spalio 3 d. koncertavo Musninku Alfonso Petrulio gimnazijoje. Lapkričio 22 d. vyko „Linksminkimos“ liaudiškos muzikos koncertas-konkursas, 
kuriame dalyvavo tik kapela, o festivalio koncerte „Šokim, trypkim, linksmi būkim“, kuris vyko Vilniaus kultūros, pramogu ir sporto rūmuose, koncertavo visas ansamblis.

Gruodžio 3 d. dalyvauta dalyvavo II respublikiniame mokyklų šokių festivalyje „Šokio vaivorykšte““ M. K. Čiurlionio menų mokyklos Šokio teatre. Gruodžio 5 d. „Vingis“ koncertavo chorų šventėje „Žiemos šviesa“, gruodžio 12 d. linksmino tarptautinio Erasmus studentų tinklo (ESN) delegatus, kuriuos dar mokè liaudišku šokių ir žaidimų.

VGTU teatro studijos „Palèpe““ repertuarą sudarė septyni skirtingi spektakliai ir per metus jų parodyta 78, kuriuose apsilankè per 3 tūkst. žiūrovų bei pastatytas premjerinis spektaklis Kobo Abès „Draugai“ ir atnaujintas Rejaus Bredberio spektaklis „Kostiumas“. Atsisveikinta ir paskutinį kartą parodyti spektakliai „Keltuvas“ ir „Peras Giuntas“. Teatro studija „Palèpė“ dalyvavo tarptautiniame studentiškų teatrų festivalyje Romoje, Italijoje, kuriame parodè spektakli „Sapfo“. Gegužès 4-10 d. Vilniuje buvo organizuotas 15-asis Tarptautinis universitetų teatrų forumas. Unikalus tokio pobūdžio renginys Baltijos šalyse šiemet kvietė pamatyti trylika spektaklių, kuriuos parengè septynios Lietuvos universitetų trupės ir svečiai iš užsienio - Ispanijos, Baltarusijos, Belgijos, Italijos ir Kanados. Beveik savaitę vyksiančio renginio tikslas - ne tik susitikti su kolegomis ar pasidalyti idèjomis, bet ir priartinti jaunimą prie teatro. Šių metų Tarptautinio universitetų teatrų forumo tema - teatrinès reminiscencijos. Ją padiktavo tai, kad 2014-ieji Lietuvoje paskelbti Teatro metais. Liježo mieste, Belgijoje, vykusiame Pasauliniame universitetų teatrų kongrese „Teatro repertuaras“ Vilniaus Gedimino technikos universiteto teatro studijos „Palèpë“ meno vadovas O. Kesminas perrinktas Tarptautinès universitetų teatru asociacijos valdybos nariu antrai kadencijai. Lapkričio pabaigoje dalyvauta VII respublikinis Lietuvos aukštujų mokyklų studentų Laimono Noreikos skaitovų konkurse Šiaulių universitete. Jame net pagal dvi kategorijas apdovanotas transporto inžinerijos studijų programos pirmo kurso studentas A. Pocius. Skaitovų konkurse taip pat dalyvavo E. Grigorjeva iš Aplinkos inžinerijos fakulteto ir A. Vaitkus, studijuojantis Mechanikos fakultete. VGTU teatro studijos „Palèpé“ 15-ojo jubiliejaus proga buvo surengtos afišų ir spektaklių nuotraukų parodos mūsų universiteto Saulètekio rūmų 5 aukšte ir LR švietimo ir mokslo ministerijoje.

VGTU orkestras surengè daug solinių koncertų: „Skambančios pavasario dūdos“ ir „Skambančios Kalèdų dūdos“ Vilniuje, Pabradejje, Širvintose. Jau tapo tradicija mūsų universitete naujus mokslo metus pradèti skambant orkestro muzikai. Lietuvos pučiamujų instrumentų orkestrų čempionate B kategorijoje laimejjo didji prizą - Grand Prix ir iškovojo teisę 2015 m. varžytis C kategorijoje. VGTU orkestrui ir jo vadovui R. Lukošiui įteiktas nominacijos „Naujai suspindusi žvaigžde““ apdovanojimas „Aukso paukštė“. Apdovanojimų ceremonija vyko kartu su orkestro koncertu Mechanikos fakulteto salèje. VGTU orkestras koncertavo bendruomenès šventèje Aukštadvaryje, Karjeros dienose, Kaziuko mugèje, Rotušes aikštėje, Gedimino dienose, renginio „Tyrèjų naktis“ atidaryme, naujametinèje bendruomenès popietėje ir kituose universiteto renginiuose. Orkestras pirmą kartą dalyvavo XVII Baltijos šalių studentų dainų ir šokių šventėje „Gaudeamus“ Daugpilyje ir jubiliejinèje Lietuvos dainų šventèje „Čia - mano namai“. Pirmą kartą vyko i tarptautini pučiamuju orkestrų festivali Lenkijoje. Rudeni Architektūros rūmų salèje surengtas bendras koncertas „Dūdos skamba viena kalba“ su pučiamuju instrumentų orkestru iš Olandijos.

\section{Sportas}

Vilniaus Gedimino technikos universiteto sporto ir turizmo klubas „Inžinerija“ organizuoja studentų ir universiteto darbuotojų sportinę veiklą. 2014 m. universitete 166 studentai sportini meistriškumą kèle klubo organizuojamose treniruotèse, 242 studentai kaip VGTU rinktinių nariai ir Lietuvos rinktinių nariai dalyvavo ịvairiose varžybose Lietuvoje ir už jos ribų. Aukšto meistriškumo universiteto sportininkai savo laimèjimais Lietuvą garsina visame pasaulyje.

Pasaulio čempionatai. Aplinkos inžinerijos fakulteto studentas T. Dauskurdas dalyvavo pasaulio svarsčių kilnojimo čempionate Hamburge (Vokietija) ir su Lietuvos jaunimo rinktine iškovojo trečiają vietą estafetès rungtyje. Antano Gustaičio aviacijos instituto studentas P. Pupinis dalyvavo Pasaulio jaunimo jègos trikovès čempionate Oroshazoje (Vengrija) ir iškovojo penktają vietą, tuo pagerino Lietuvos jaunimo jègos trikovės rekordą. Atskiroje atkèlimo rungtyje P. Pupinis iškovojo trečiają vietą. Transporto inžinerijos fakulteto studentas A. Domeika atstovavo Lietuvos stalo teniso komandai pasaulio stalo teniso čempionate Tokijuje (Japonija).

Europos čempionatai. Antano Gustaičio aviacijos instituto studentas P. Pupinis dalyvavo Europos jaunimo jègos trikovès čempionate Sankt Peterburge (Rusija), kuriame iškovojo ketvirtają vietą, o atskiroje pritūpimo rungtyje - trečiają.

Europos universitetų žaidynės. II Europos universitetų studentų žaidynėse Roterdame (Olandija) teisę dalyvauti iškovojo universiteto stalo teniso komanda, kurioje žaidè M. Vilkas (Statybos fakultetas), T. Domeika 
(Transporto inžinerijos fakultetas) ir A. Preidžius (Verslo vadybos fakultetas). VGTU komanda iškovojo aukštą devintają vietą tarp dvidešimties Europos universitetų komandų.

SELL žaidynès. Tarptautinėse studentų žaidynėse Tartu (Estija) dalyvavo septynių sporto šakų sportininkai iš VGTU. Jie iškovojo dešimt medalių: stalo teniso - vieną bronzos (dvejetų varžybos: M. Vilkas iš Statybos fakulteto ir T. Domeika iš Transporto inžinerijos fakulteto), dziudo imtynès - vieną sidabro (S. Zubarev iš Mechanikos fakulteto) ir du bronzos (D. Damskis iš Transporto inžinerijos fakulteto ir M. Burba iš Aplinkos inžinerijos fakulteto), graikų romėnų imtynès - vieną bronzos (B. Keršys iš Aplinkos inžinerijos fakulteto), jègos trikovè - vieną sidabro (P. Pupinis iš Antano Gustaičio aviacijos instituto), lengvoji atletika - vieną sidabro (K. Juknytè (disko metimo rungtis) iš Aplinkos inžinerijos fakulteto) ir du bronzos medalius (K. Juknytè (rutulio stūmimo rungtis) ir D. Aučyna (trišuolio rungtis) iš Statybos fakulteto).

Lietuvos čempionatai. Pirmą kartą universiteto sporto istorijoje du mūsų auklètiniai susitiko kovoje dèl Lietuvos stalo teniso čempiono vardo ir kelialapio i pasaulio čempionatą, kuris vyko Tokijuje (Japonija). Pirmają vietą iškovojo Transporto inžinerijos fakulteto studentas A. Domeika, antrają vietą - Statybos inžinerijos fakulteto studentas M. Vilkas. A. Preidžius (Verslo vadybos fakultetas) stalo teniso dvejetų varžybose iškovojo pirmają vietą. Lietuvos jaunimo jègos trikovės ir Lietuvos štangos spaudimo čempionatuose Antano Gustaičio aviacijos instituto studentas P. Pupinis iškovojo pirmąsias vietas. Lietuvos sambo čempionate universiteto imtynininkai S. Zubarev (Mechanikos fakultetas), R. Žukovskis (Transporto inžinerijos fakultetas) iškovojo pirmąsias vietas, E. Mackevič (Verslo vadybos fakultetas) - trečiają. Lietuvos U-21 dziudo imtyniu čempionate E. Mackevič iškovojo trečiają vietą. Lietuvos vyrų rankinio I lygos čempionate universiteto rankinio komanda užèmè penktają vietą. I lygos komandiniame stalo teniso čempionate universiteto komanda užèmè trečiają vietą.

Lietuvos studentų čempionatai. Salès futbolo, stalo teniso ir keliautojų sporto čempionatuose iškovotos pirmos vietos. Antroji vieta iškovota svarsčių kilnojimo čempionate. Trečiąsias vietas iškovojo dziudo imtynių, futbolo, irklavimo, tinklinio (vaikinų), paplūdimio tinklinio (vaikinų) komandos. Ketvirtos vietos iškovotos jẻgos trikovès, teniso, sambo (vaikinai), kroso (vaikinai), paplūdimio tinklinio (merginos) lengvosios atletikos uždaru patalpų ir lengvosios atletikos čempionatuose. Penktąsias vietas iškovojo sambo (merginų), tinklinio (merginų) komandos

Tarptautiniai turnyrai. Telšiuose vykusiame stalo teniso tarptautiniame turnyre, skirtame treneriui Vytautui Giedraičiui atminti, du mūsų universiteto stalo tenisininkai (Transporto inžinerijos fakulteto studentai) iškovojo prizines vietas: A. Domeika - antrają, o T. Domeika - trečiają. Lengvosios atletikos Baltijos technikos universitetų turnyre (Klaipėda) universiteto komanda iškovojo antrają vietą.

Vilniaus miesto čempionatai. Krepšinio A lygos čempionate universiteto krepšininkai reguliariajame sezone iškovojo trečiają vietą. Tinklinio moterų čempionate VGTU tinklininkės užèmé penktą vietą.

VGTU turnyrai. Universiteto bendruomenès nariams nuolat organizuojamos îvairios sporto varžybos. Buvo vykdomi tinklinio, krepšinio, futbolo, teniso, stalo teniso, šachmatų turnyrai darbuotojams ir studentams. Taip pat buvo organizuotos kasmetinès „Kalnų kelionių technikos“ varžybos Gedimino taurei laimèti, V. Špiliausko taurès VGTU turistų klubo vandens turizmo technikos varžybos. Rankinio turnyras docentui V. Sakaliui atminti ir VGTU rektoriaus taurès metikų veteranų daugiakovės varžybos, kuriose dalyvavo sportininkai iš visos Lietuvos.

\section{Studentų veikla}

Mokslinè ir praktinė studentų veikla. Studentų mokslinės veiklos skatinimas ir jaunujų tyrèjų ugdymas - svarbios universiteto veiklos kryptys. Visuose VGTU fakultetuose 2014 m. organizuotos jaunuju mokslininkų konferencijos, kuriose ivairių pakopų studentai pristatè savo mokslinius projektus ir tyrimus, atradimus ir inovaciju prototipus. $2014 \mathrm{~m}$. jaunujų mokslininkų konferencijos pavadinimu „Mokslas - Lietuvos ateitis“ organizuotos jau 17-aji kartą.

VGTU studentai dalyvavo 2014 m. VGTU ir Lietuvoje organizuotose olimpiadose ir mokslo populiarinimo renginiuose.

Po respublikinio projekto „Mokslo pieva“ atrankos i penkias projekto komandas pateko keturi VGTU studentai: G. Drabavičius (Fundamentinių mokslų fakultetas), G. Stogis (Architektūros fakultetas), D. Tamutytè ir A. Lutcaitè (Kūrybinių industrijų fakultetas). Jie kartu su žymiais Lietuvos mokslininkais sudarè tarpdisciplinines tyrimų grupes ir atliko aktualius šaliai tyrimus.

Klaipėdoje vykusioje respublikinèje medžiagu mechanikos olimpiadoje visi penki VGTU atstovai pateko i geriausiuju dešimtuką. Antrają vietą užèmė Statybos fakulteto studentè A. Ramelytè. To paties fakulteto studentas M. Stonkus užèmė penktają vietą, o kiek mažiau balų surinkę studentai N. Zaveckaitè, G. Zabitytè ir P. Stropas pasidalijo septintą, devintą ir dešimtą vietas. Jiems buvo įteikti diplomai ir apdovanojimai. 
Kelios dešimtys VGTU studentu buvo apdovanoti už kūrybingas, inovatyvias idèjas, darbus, mokslo rezultatus:

- Lietuvos mokslu akademijoje asociacija INFOBALT apdovanojo geriausius jaunuosius mokslininkus, atliekančius fiziniu ir technologijos mokslu tarpdalykinius tyrimus. Tarp skatinamuju stipendiju laureatu pateko ir du VGTU studentai - A. Dzedzickis (Mechanikos fakultetas) bei T. Sledevič (Elektronikos fakultetas).

- Švietimo ir mokslo ministerija Prezidento Jono Žemaičio stipendiją skyrè VGTU Aplinkos inžinerijos fakulteto pastatu energetikos III kurso studentui A. Kavolynui.

- Švietimo ir mokslo ministerija paskelbė trečius metus organizuojamo Mokslinių tyrimu ir eksperimentinès plètros rezultatŭ komercinimo konkurso nugalètojus. Tarp aštuoniolikos geriausių verslą pradedančiu imoniu projektu, kuriems itteikti iki 70 tūkst. litu paramos čekiai, pateko ir VGTU verslą pradedanti UAB „Icus LT“. Bendrovės kūrẻjai - Elektronikos fakulteto magistrantai T. Petrulevičius ir A. Gedminas pasiūlè, kaip nuotoliniu būdu patikrinti duru užrakto būseną.

- Tarptautinèje kosmoso ekonomikos konferencijoje ivyko mokomuju palydovu „CanSat“, raketu ir bepiločiu orlaivių konkurso apdovanojimai. "CanSat“ kategorijoje antrają vietą užėmé komanda "Marso gélès“, kuriai priklausė ir VGTU trečio kurso automatikos studentas T. V. Žvinys. Trečiają vietą užėmė komanda „VGTU CanSat-2“, kurią sudarè vien VGTU studentai - Elektronikos fakulteto magistrantai E. Šabanovič, E. Korsakas ir A. Šabanovič iš Mechanikos fakulteto. Bepiločiu orlaiviụ komandoms buvo skirtos dvi pirmosios vietos, vieną ju užèmé komanda „VGTU AGAl“, kurią sudaré studentai K. Kirijanovas, K. Jankauskas, K. Kaupas ir M. Petruška.

- Kasmet Integracijos ir karjeros direkcijos organizuojamu „Karjeros dienu“ Kontaktų mugés uždarymo vakarẻlyje trims VGTU studentams pirmąkart iteiktos vardinès „Eikos“ stipendijos už akademinius ir mokslo pasiekimus. 3 tūkst. litu vertès stipendijas gavo Statybos fakultete studijuojantys bakalaurantas P. Stropas, magistrantas M. Macijauskas ir doktorantė S. Kildienè. Jas iteikè tuometis „Eikos“ plètros vadovas D. Dargis.

- Perspektyviausiu architektūros studentu Lietuvoje 2014 m. tapo VGTU architektūros studentas D. Baltrūnas. Iš penkių konkurso finalistų atrinktas studentas buvo apdovanotas žymaus architekto A. Dineikos vardo stipendija.

Verslumo ugdymas ir karjera. Universitete studentu verslumo ugdymas - prioritetinè ugdymo kryptis, i kurią investuojama ne tik laiko, bet ir lèšu.

Siekiant studentus supažindinti su būsimais darbdaviais, darbo aplinka ir principais, karjeros galimybėmis ir verslo aplinka, $2014 \mathrm{~m}$. VGTU organizuotos studentu ekskursijos i i vairias verslo imones. Studentai keliavo i IT kompanijas, bankus, automobiliu pardavimo ir techninès priežiūros salonus, logistikos bendroves ir kt. Taip pat organizuoti paskaitu ciklai, atviros paskaitos ivairia tematika. Pagalbą ir konsultacijas studentai gali gauti Verslo vadybos fakulteto verslumo centre bei Žiniu ir technologiju perdavimo centre.

VGTU studentai skatinami kurti inovacijas ir savo verslus, taip pat mokomi pagrindiniu verslumo principu, kurie padeda valdyti jaunas ịmones, ieškoti finansinès paramos, plèsti žinomumą apie jas, rasti bendraminčių.

- 2014 m. organizuoti „Social Face“ mokymai, kuriu metu ivairiu sričiu profesionalai suteikè studentams žinių, kaip pristatyti save, savo būsimą imonę, kaip savo tikslams igyvendinti naudoti socialines medijas.

- VGTU ir Šiaurès miestelio technologiju parko kuruotame „Inovatyviu verslu skatinimo“ projekte baigèsi pirmasis etapas, kuriame VGTU ikūre keturias technologines imones. Elektronikos fakulteto studentai naujoje imonèje sprendžia problemą, susijusią su duru rakinimu. Sistema „Rakink“ leidžia prisijungti prie interneto svetainès ar mobiliojo telefono programèlès ir nuotoliniu būdu patikrinti duru užrakto būseną. Kiti penki VGTU studentai jkūrè imonę „Realybès vartai“: komanda plètoja papildytosios realybės technologija, kuria mobiliąsias ir kompiuterines programas, integruoja papildytosios realybès technologijas i visuomenę. VGTU absolventas M. Juršys ikūre mažają bendriją „Metanoja“, kurios pagrindinè veikla - padèti spręsti taršos problemas iš natūraliụ celiuliozinių medžiagu išgaunant celiuliozès nanokristalus. Ketvirtoji imonè - „Pasyvios energijos grupè“, kurią ikūrè studentai, radę būdą apšvietimui skirtos energijos sąnaudas sumažinti net 40 proc.

Savanoriška ir socialinè studentų veikla. VGTU studentai skatinami ne tik gerai mokytis, kurti inovacijas ir verslus, bet ir tapti socialiai atsakingais bei pilietiškais pasaulio ir Lietuvos gyventojais. Didelę dali savanorišku veiklu ir iniciatyvu kuruoja VGTU studentu atstovybé, kuri 2014 m. atšventė 20-aji jubilieju, išrinko naują SA pirmininkę L. Ladietaitę, taip pat persikraustè i naujas patalpas - atskirą namą, esanti netoli VGTU centrinio korpuso Saulètekyje.

Savanoriškus ir socialinès studentu veiklos projektus koordinavo ne tik VGTU studentu atstovybè ir jos padaliniai, $2014 \mathrm{~m}$. iniciatyvūs buvo ir atskiri ịvairiụ fakultetų studentai:

- „Erasmus studentu tinklo“ (ESN) atstovai iš visos Europos rinkosi i VGTU studentu organizuotą kasmetini nacionaliniu delegatụ susitikimą, kuriame buvo sprendžiami tarptautiniams studentams aktualūs klausimai. 
- VGTU SA ir Gruzijos organizacija „Young Generation“ vykdè „Lithuanian Youth Camp“ projektą, kurio metu Lietuvoje savaitę viešejjo dešimt studentu iš Gruzijos. Projekto metu studentai dalyvavo neformaliuose lyderystès, komandos formavimo, projektų rengimo ir kitų naudingų igūdžių suteikiančiuose mokymuose. Jaunuoliai diskutavo apie studentų savivaldą, jų struktūrą skirtingose šalyse, dalijosi patirtimi ir gerosios praktikos pavyzdžiais.

- VGTU architektūros studentų kursiniai darbai buvo skirti Vilniaus Radvilų gimnazijos teritorijos ir Šeškinès mikrorajono aplinkos tvarkymo temai nagrinèti. Trečio kurso studentai grupėmis po 2-5 žmones analizavo gimnazijos ir jos prieigų aplinką, nustatė problemines zonas bei remdamiesi panašių kraštovaizdžio situacijų projektais siūlè savo idèjas, kaip tvarkyti teritoriją.

- Kūrybinių industrijų programos studentai jau trečius metus organizavo kūrybinių intervencijų savaitę „priARTink“, kurios metu bandè įkvėpti gyvybės mažiau lankomiems Vilniaus parkams ir skverams.

- Aplinkos inžinerijos fakulteto SA surengè akciją prieš rūkymą. Akcijos metu studentai galëjo pasitikrinti plaučius, pasikeisti cigaretes ì saldainius, nusifotografuoti prie sienos su žmogumi-cigarete, dalyvauti balionų pūtimo varžybose. Šia akcija buvo siekta paskatinti rūkančius studentus susirūpinti savo sveikata, atsisakyti žalingo ipročio.

- VGTU studentai aktyviai dalyvauja Generolo Jono Žemaičio Lietuvos karo akademijoje vykstančiuose jaunesniujų karininkų vadų mokymuose, kuriuose rengiami rezervo pėstininkų būrių vadai. Mokymuose jie igyja pagrindinį karini parengtumą, pasirengia veikti kariniame vienete ir jam vadovauti. Sėkmingai baige trejų metų trukmės kursą klausytojai igyja rezervo būrio vado kvalifikaciją ir jiems suteikiamas atsargos jaunesniojo karininko (leitenanto) karinis laipsnis.

Vilniaus jaunimo organizacijų sajunga „Apskritas stalas“ (VJOSAS) tradiciniuose jaunimo organizacijų apdovanojimuose ivertino VGTU SA narius ir jų koordinuotus projektus. Metų lyderiu paskelbtas VGTU SA prezidento pareigas dvi kadencijas èjęs D. Martsinkevichus. Metų projektu tapo akcija „Nusirašinėk legaliai: naudok savo smegenis“, o metų renginiu - Tarptautinè studentų diena, kurios šventimą organizavo VGTU ir kitų universitetų studentų atstovybès. 


\section{Svarbiausi 2014 metų ivykiai}
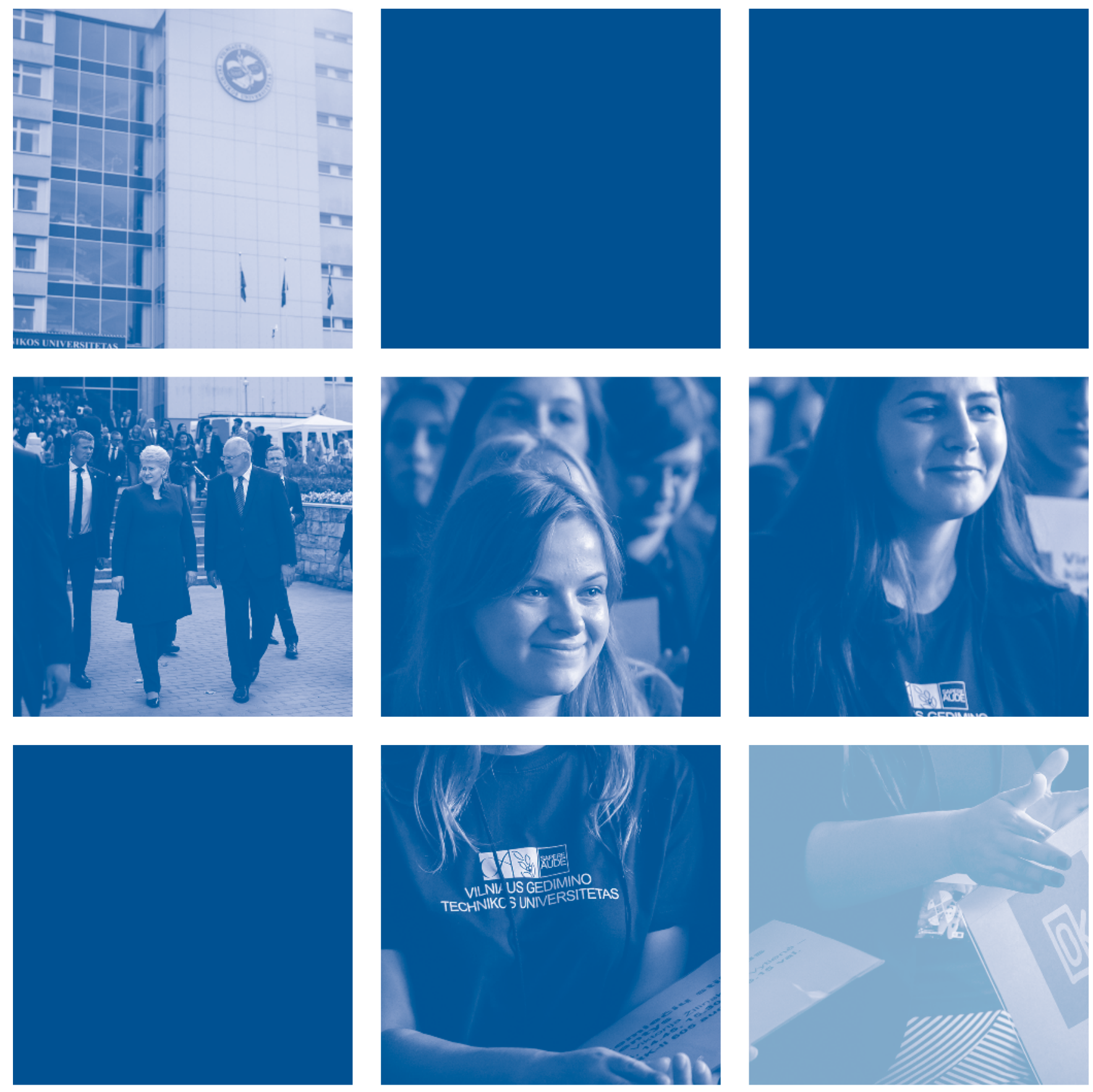



\section{Svarbiausi 2014 metu ivykiai}

\section{Sausis}

VGTU igyvendinta mokslo padalinių struktūros pertvarka.

VGTU bibliotekoje atidaryta universiteto socialinio partnerio - Klaipėdos valstybinio jūru uosto direkcijos paroda apie Klaipėdos uosto raidą. I trijų studentų bendrabučių atnaujinimą VGTU investuoja 7,5 mln. litų.

Švietimo ir mokslo ministras Dainius Pavalkis lankèsi VGTU Civilinės inžinerijos mokslo centre.

\section{Vasaris}

VGTU profesoriui Gintariui Kaklauskui įteikta Lietuvos mokslo premija.

VGTU bibliotekoje Švedijos ambasada surengè parodą „Akistata su klimatu“.

VGTU pučiamujų orkestras pripažintas geriausiu „Aukso paukštės“ apdovanojimuose.

Kompiuterių inžinerijos studentai sukūrè nuotoliniu būdu valdomą robotinę ranką.

Universitetą aplankè Jungtinių Amerikos Valstijų ambasadorė Lietuvoje Deborah Ann McCarthy. Ji skaitė atvirą paskaitą studentams „Pasaulio ekonomikos iššūkiai ir JAV užsienio ekonominè politika“.

Leidykla „Technika“ dalyvavo „Vilniaus knygų mugèje“.

VGTU dalyvavo studiju parodoje „Studijos 2014“.

INFOBALT skatinamosiomis stipendijomis apdovanojo du VGTU Mechanikos ir Elektronikos fakultetų studentus - Andrių Dzedzicki (Mechanikos fakultetas) ir Tomyslavą Sledevičių (Elektronikos fakultetas).

Studentų futbolo komanda iškovojo pirmają vietą Lietuvos studentų salès futbolo čempionate.

\section{Kovas}

Automobilių taupumo žygyje VGTU komanda užėmė prizines vietas.

VGTU pasirašè strateginio bendradarbiavimo sutarti su tarptautine informacinių technologiju kompanija „Bentley Systems“.

Teatro studija „Palèpė“ pakvietè ị premjerą - Kobo Abès pjesę „Draugai“.

VGTU su Rygos universitetu pasirašè dvi jungtinių studiju programų sutartis.

Universitetas pristatytas studijų parodoje Brazilijoje.

Rektorius pristatè 2013 metų universiteto veiklos ataskaitą.

VGTU elektronikų kurtas vandens tiekimo savikainą mažinantis dažnio keitiklis pristatytas pasaulinei rinkai. Verslo vadybos fakultetas tapo prestižinių Centrinès ir Rytu Europos vadybos asociacijos (CEEMAN) ir Europos vadybos plètros fondo (EFMD) nariu.

VGTU dalyvavo APIEA studiju parodoje Seule.

\section{Balandis}

VGTU mokslo pasiekimai pristatyti JAV Niujorko žaliujų technologijų mugejje.

Pateikta pirmoji VGTU patentinė paraiška Japonijos patentų tarnybai - Mechanikos fakultete sukurtą „Plieninio lyno kokybès diagnostikos būdą ir įrangą“.

VGTU kartu su 32 kitomis valstybinėmis institucijomis ir visuomeninėmis organizacijomis pasirašè memorandumą dèl saugaus eismo gerinimo ir eismo kultūros ugdymo Lietuvoje.

Europos jaunimo jėgos trikovès čempionate pritūpimo rungtyje VGTU studentas iškovojo 3-iają vietą.

Gautos VGTU išorinio vertinimo išvados: visas veiklos sritis ekspertai ivertino teigiamai.

VGTU orkestras Lietuvos pučiamuju orkestrų čempionate laimejjo „Grand Prix“.

Pristatyta VGTU elektronikų inovacija onkologinių ligu diagnostikai palengvinti. 
VGTU biblioteka dalyvavo Nacionalinės bibliotekų savaitės renginiuose Prezidentūroje.

Prezidentūroje apdovanoti du VGTU daktarai, pripažinti geriausių disertacijų Lietuvoje autoriais - architektas Justinas Bučys ir aplinkosaugininkè Inga Jakštonienè.

VGTU mokslininkai pristatė išmaniają ryšio technologiją, galinčią paspartinti belaidị internetą.

İregistruotos trys naujos studijų programos: programų inžinerija, architektūros inžinerija, inovatyvi kelių ir tiltų inžinerija.

\section{Gegužè}

Ikurtas Statinių skaitmeninio ir informacinio modeliavimo technologiju (angl. BIM) centras.

VGTU Studentų atstovybè šventè 20-aji gimtadienị.

VGTU komanda - $2013 \mathrm{~m}$. Lietuvos laivų modelių sporto čempionato nugalètoja.

VGTU teatro studija „Palèpe்“ organizavo 15-aji tarptautinį universitetų teatrų forumą.

Transporto inžinerijos fakultetas šventè veiklos 20-metị.

Studentai per „Inžinierių dienas“ surengè jau 20-aji šventini automobilių slalomą „Transmechanija“.

Paskelbti „U-Multirank“ reitingai: VGTU gavo daugiausia teigiamų ivertinimu, palyginti su kitais Lietuvos universitetais.

VGTU atidaryta Kūrybinių industrijų laboratorija.

Pirmą kartą VGTU ịteikè neformaliąsias kompetencijas įteisinančius pažymėjimus.

VGTU akademinis choras „Gabija“ filharmonijoje atšventè 50-meti.

Tarptautinėse studentų SELL žaidynėse VGTU studentai iškovojo dešimt medalių.

VGTU ịvyko 9-oji tarptautinè konferencija „Aplinkos inžinerija“.

Mokslinèje konferencijoje „Business and Management '2014“ pranešimus skaitè mokslininkai iš 22 šalių.

VGTU lankėsi Hiustono universiteto vadovų magistrantūros studentų ir dėstytojų grupè.

Vyko atvira elektros, elektronikos ir informatikos mokslų konferencija „eStream 2014“ ir 3-ioji IEEE Lietuvos sekcijos organizuota konferencija „BISI-2014“.

VGTU lankèsi Europos universitetų asociacijos (EUA) ir Akademinio bendradarbiavimo asociacijos (ACA) ekspertai. I VGTU atvyko Omano sultonato atstovai, kurie domèjosi partneryste su VGTU.

VGTU dalyvavo studiju parodoje NAFSA, San Diege (JAV).

\section{Birželis}

İregistruotos šešios naujos studiju programos: avionika, pastatų inžinerinis valdymas, inovatyvūs sprendimai geomatikoje, finansų inžinerija, mechatroninès sistemos ir jungtinė studijų programa mechatronika.

VGTU mokslininko E. K. Zavadsko pavardè įtraukta į kompanijos „Thomson Reuters“ sudarytą daugiausia cituojamų mokslininkų sąrašą

IBM pagamino VGTU elektronikos inžinierių sukurtą išmanuji elektronikos lustą.

Vilniaus Vytauto Didžiojo ir Kèdainių Šviesiojoje gimnazijose įsteigtos naujos VGTU klasės.

VGTU suorganizuota oro kadetu vasaros stovykla.

VGTU vyko tarptautinio studentų tinklo OCEANS NETWORK kasmetinis susitikimas.

Jubiliejiniam 6000-ajam Transporto inžinerijos fakulteto absolventui įteiktas diplomas.

VGTU lankėsi Taipėjaus nacionalinio technologijos universiteto delegacija.

\section{Liepa}

VGTU studentams įteikti diplomai.

Tarp VGTU studentų baigiamujų darbų - 3D spausdintuvo ir frezavimo staklių prototipai.

VGTU įregistravo dvi naujas studijų programas - verslo logistiką ir kokybės inžineriją.

Teatro studija „Palėpė“ Romoje studentiškų teatrų festivalyje pristatė spektakli „Sapfo“.

Kartu su Kalifornijos valstybiniu politechnikos universitetu vykdoma „VGTU - CalPoly'2014“ vasaros mokykla sugrįžo ì VGTU.

INOVEKS projekte VGTU su Šiaurès miestelio technologijų parku j̇kūrè 22 įmones, 14-oje jų dirba VGTU studentai. 
„Palèpès“ vadovas perrinktas Tarptautinès universitetu teatru asociacijos valdybos nariu.

Pradèti Elektronikos, Mechanikos ir Transporto inžinerijos fakultetụ laboratoriju korpuso, Elektronikos fakulteto bei Mechanikos ir Transporto inžinerijos fakultetų mokomuju korpusų VGTU Sauletekio studentų miestelyje projektavimo darbai.

\section{Rugpjūtis}

Naujai gauta teisè rengti aplinkos inžinerijos mokslo krypties mokslo daktarus.

VGTU kompiuteriu inžinerijos studentas sukūrè mobiliuoju telefonu valdomą robotą kamuoli.

Dukart per metus skelbiamuose reitinguose „Webometrics“ VGTU užèmè antrą vietą po Vilniaus universiteto.

Tarp 18 geriausių naujai kuriamu imonių projektu Lietuvoje apdovanota ir VGTU ikurta imonè „Icus LT“.

Pagal paskelbtus bendrojo priemimo rezultatus VGTU - antras Lietuvoje.

VGTU prisijungè prie geros verslo praktikos, ivedant eurą, memorandumo.

Iregistruota nauja jungtine VGTU ir Maskvos valstybinio M. V. Lomonosovo universiteto studiju programa „Statiniu ir ju aplinkos darni plètra“.

VGTU vyko tarptautinè vasaros mokykla SOCIAL FACE.

\section{Rugsejjis}

VGTU suorganizuota žinių ir mokslo metų pradžios šventè.

Festivalio „Erdvèlaivis Žemè“ Mokslo atradimu dieną VGTU atidarè Lietuvos Respublikos Prezidentė Dalia Grybauskaitè.

VGTU bibliotekoje atidaryta doc. Kęstučio Skerio kolekciniu pieštuku paroda.

Reitinge „2014-2015 QS World University Rankings“ VGTU pateko tarp keturių Lietuvos aukštosios mokyklos, tarp kuriu - ir VGTU.

VGTU pasiraše bendradarbiavimo sutarti su bendrove „Lietuvos paštas“.

„Gedimino dienos“: linksmybès ir kūrybingi eksperimentai - vienoje vietoje.

Pradèti VGTU Antano Gustaičio aviacijos instituto Treniruokliu ir laboratoriju korpuso statybos darbai. VGTU mokslininkai dalyvavo „Tyrèju naktyje“.

VGTU studentas pasaulio jègos trikovès čempionato štangos atkèlimo rungtyje - trečias.

Ivyko dvidešimties metu gaisrinès saugos specialybès absolventu sąšauka.

Universitete - „Business Express“: verslo profesionalai iš užsienio i̇moniu perskaitė daugiau nei 30 paskaitų. VGTU tapo Kinijos ir VRE universitetụ bendradarbiavimo asociacijos kūrimo signataru

\section{Spalis}

Doc. dr. Olegas Prentkovskis ivertintas Ukrainos statybos akademijos „Didžiuoju sidabro medaliu“.

Prof. dr. Olegui Vasilecui suteiktas Latvijos universiteto garbès daktaro vardas.

Ūkio ministerija konkurse už patrauklias verslo idejjas ir ekonomines ižvalgas VGTU magistrams skyrè pirmą ir antrą vietas.

Verslo i̇monėje sėkmingai įdiegta VGTU mechatronikos absolvento inovacija - mechatroninė klimato valdymo ir energijos sąnaudu kontrolès sistema.

VGTU lankèsi „Solar Impulse“ projekto lyderis Hannes Ross.

VGTU dalyvavo studiju parodoje Abu Dabyje.

Pradèti VGTU studentų bendrabučio atnaujinimo darbai.

VGTU Antano Gustaičio aviacijos institute vyko tarptautinė konferencija READ 2014.

VGTU studentu atstovybè persikèlè ị naujas patalpas.

\section{Lapkritis}

lkurtas VGTU Žinių ir technologiju perdavimo centras.

VGTU pasirašè sutarti su šalies Nacionaline pasyvių namu asociacija.

VGTU gavo nacionalinị apdovanojimą už geriausią Erasmus programos viešinimą ir rezultatų sklaidą. 
VGTU dalyvavo Europos aukštojo mokslo parodoje Vietname.

VGTU įstojo i Lietuvos kokybės vadybos ir inovacijų asociaciją.

Universitete vyko Atvirų durų diena.

Pristatyta nauja VGTU.LT interneto svetainè.

Vyko tarptautinè konferencija „Contemporary Issues in Business, Management and Education '2014“.

VGTU Informacinių technologijų centras (IT) dalyvavo pasauliniame kongrese „Live Mobile“.

VGTU viešėjo kolegos iš Japonijos Kobès universiteto, su kuriuo pavasarị buvo pasirašyta bendradarbiavimo sutartis.

\section{Gruodis}

Aukštojo mokslo mugèje Indijoje VGTU ir Indijos technologijų institutas Delyje susitarè pasirašyti institucinę bendradarbiavimo sutarti.

VGTU dalyvavo Baltijos šalių technologijos universitetų rektorių konferencijoje.

VGTU studentas iš pasaulio svarsčių kilnojimo čempionato grižo su medaliu.

VGTU studentų atstovybės prezidente tapo Laura Ladietaitè.

VGTU dėstytojas architektas Rolandas Palekas tapo Lietuvos nacionalinès kultūros ir meno premijos laureatu.

ESN VGTU ị Vilnių sukvietė didžiausios Europos studentų organizacijos atstovus.

Žurnalas „Reitingai“: VGTU pirmauja pagal penkias studijų kryptis.

Ugdymo plètotès centras kartu su VGTU organizavo 3D spausdinimo dirbtuves mokiniams.

VGTU rektorius tapo Lietuvos universitetų rektorių konferencijos prezidentu.

VGTU įkurta nauja įmonè pristatė ekologiškas pakuotes iš kanapių pluošto.

QS reitingas „2014-2015 m. Emerging Europe and Central Asia“: VGTU yra antras universitetas Lietuvoje. VGTU pradejjo inovacijų ir kūrybinių industrijų centro „LINK MENŲ fabrikas“ statybas.

Choras „Gabija“ dalyvavo XI tarptautinèje choru šventėje „Žiemos šviesa“.

Doc. dr. Almantas Samalavičius apdovanotas Broniaus Savukyno premija. 


\section{Priedai}

\section{Leidyklos „Technika“ 2014 m. leidiniai}

\section{Monografijos}

1. Butkus, D.; Lukšienè, B.; Pliopaitè Bataitienè, I. Radionuklidai augaluose: monografija. V.: Technika. 296 p., ISBN 978-609-457-669-0, elSBN 978-609-457-668-3; doi:10.3846/2243-M. VGTU kodas 2243-M.

2. Gnip, I.; Vaitkus, S.; Vejjelis, S.; Keršulis, V. Polistireninis putplastis: fizikinių ir mechaniniu savybiu jivertinimas: monografija. V.: Technika. 180 p., ISBN 978-609-457-477-1, elSBN 978-609-457-476-4; doi:10.3846/2126-M. VGTU kodas 2126-M.

3. Jakovlevas-Mateckis, K. Miesto kraštovaizdžio architektūra. Miesto kraštovaizdžio architektūros objektu formavimo principai: monografija III tomas. V.: Technika. 348 p., ISBN 978-609-457-534-1, eISBN 978-609-457-533-4; doi:10.3846/2153-M. VGTU kodas 2153-M.

4. Jurevičienè, J.; Burinskienè, M.; Genytè, I.; Kalibatas, D.; Šiupšinskas, G. Inovatyvūs regeneravimo metodai ir jų modeliavimas: Panemunès pilis: monografija. V.: Technika. 170 p. ISBN 978-609-457-730-7, elSBN 978-609-457-729-1; doi:10.3846/2284-M. VGTU kodas 2284-M.

5. Juzefovič, A. Tuštumos fenomenas. Tuštumos sklaida daoizme, fenomenologinèje filosofijoje, kinu ir vakaru estetikoje bei daileje: monografija. V.: Technika. 272 p., ISBN 978-609-457-479-5, elSBN 978-609-457-478-8; doi:10.3846/2241-M. VGTU kodas 2241-M.

6. Kačerauskas, T. Kūrybos visuomenè: monografija. V.: Technika. 400 p., ISBN 978-609-457-762-8, elSBN 978-609-457-761-1; doi:10.3846/2265-M. VGTU kodas 2265-M.

7. Kaulakienè, A. Terminologija. Terminija: straipsniu rinkinys. V.: Technika. 448 p. ISBN 978-609-457-557-0, elSBN 978-609-457-556-3; doi:10.3846/2151-M. VGTU kodas 2151-M.

8. Navakauskas, D.; Serackis, A.; Matuzevičius, D.; Laptik, R. Specializuotos elektroninès intelektualiosios sistemos garsams ir vaizdams apdoroti. Teorija ir taikymai: monografija. V.: Technika. 574 p. ISBN 978-609-457-768-0, elSBN 978-609-457-767-3; doi:10.3846/2310-M. VGTU kodas 2310-M.

9. Pruskus, V. Politika ir pramogos komunikacijos kontekste: monografija. V.: Technika. 176 p., ISBN 978-609-457-637-9, eISBN 978-609457-636-2; doi:10.3846/2231-M. VGTU kodas 2231-M.

10. Каклаускас, А.; Завадскас, Э.; Бардаускене, А.; Ааргис, Р. Гармоничное развитие неАвижимого имущества: monografija. V.: Technika. 424 p., ISBN 978-609-457-764-2, eISBN 978-609-457-763-5; doi:10.3846/2309-M. VGTU kodas 2309-M.

\section{Moksliniai publicistiniai leidiniai}

11. Daniūnas, A.; Kliukas, R.; Prentkovskis, O. Specialybės, keičiančios pasauli: informacija apie Vilniaus Gedimino technikos universiteto 2014 m. bakalauro studiju programas: informacinis leidinys. V.: Technika. 160 p., ISBN 978-609-457-621-8, eISBN 978-609-457-620-1. VGTU kodas 1490-S.

12. Norkevičius, J. Merkio palydètas i mokslo kelią. Profesoriaus Petro Čyro gyvenimo bruožai. V.: Technika. 176 p., ISBN 978-609-457-558-7. VGTU kodas 010-P.

13. Ulinskaitè, D.; Prentkovskis, O. Magistrantūros studijos Vilniaus Gedimino technikos universitete 2014 m.: informacinis leidinys V.: Technika. 48 p., ISBN 978-609-457-646-1, eISBN 978-609-457-645-4. VGTU kodas 012-P.

14. Handbook for International Students. V.: Technika. 32 p., ISSN 2029-0179. VGTU kodas 011-P.

15. Neprarastu dienu metai. Akademikas Edmundas Kazimieras Zavadskas. Sudarytojas Liekis, A. V.: Technika. 400 p. ISBN 978-609-457-677-5. VGTU kodas 015-P.

16. Šis tas apie mūsu Motiną. Sudarytojas Kesminas, O. V.: Technika. 254 p. ISBN 978-609-457-656-0; elSBN 978-609-457-655-3. VGTU kodas 013-P.

17. Transporto inžinerijos fakultetui - 20 metu. Sudarytojai: Bartulis, V.; Nagurnas, S.; Bobinienè, V.; Valčackienè, N.; Dabulevičienė, L. V.: Technika. 214 p. ISBN 978-609-457-680-5. VGTU kodas 016-P.

18. Verslo vadybos fakultetui - 20 metu. Sudarytojai: Stankevičienè, J.; Miečinskienè, A.; Raudeliūnienè, J.; Dzemyda, I.; Lapinskaitė, I.; Činčikaitè, R.; Martinkutè-Kaulienè, R.; Ginevičius, R.; Skačkauskienè, I.; Melnikas, B.; Mitkus, S.; Davidavičienè, V. V.: Technika. 80 p. ISBN 978-609-457-693-5. VGTU kodas 017-P.

19. Vilniaus Gedimino technikos universiteto teatras studija „Palèpe“. V.: Technika. 60 p. VGTU kodas 018-P.

20. Mokslo darbai ir leidiniu serijos

21. Vilniaus Gedimino technikos universitetas - 2013 metai. Mokslinis informacinis leidinys „Mokslas, studijos, universiteto gyvenimas“, Nr. 47, 2014. V.: Technika. 122 p. ISSN 1392-1436. VGTU kodas 2242-M.

22. Metai ir dienos. VGTU 2012 m. Sudaré Keliotienè, R.; Liekis, A. V.: Technika. 310 p. ISSN 1822-0576, elSSN 2351-4590; doi:10.3846/2229-M. VGTU kodas 2229-M.

23. Metai ir dienos. VGTU 2013 m. Sudaré Keliotienè, R.; Liekis, A. V.: Technika. 504 p. elSSN 2351-4590; doi:10.3846/014-P. VGTU kodas 014-P.

24. Jurevičienè, J.; Burinskienè, M.; Genytè, ı.; Šiupšinskas, G. Raudonu plytu mūro architektūros paveldo pastatu regeneravimo metodika: Panemunès pilys: mokslo studija. V.: Technika. 60 p., ISBN 978-609-457-720-8, elSBN 978-609-457-719-2; doi:10.3846/2272-M. VGTU kodas 2272-M. 


\section{Mokslininkų bibliografinės rodyklès}

25. Petras Čyras. Bibliografinè rodyklè. Habilituoti daktarai. Sudarè Juršaitè, O.; Vidūnaitè-Stankevičienė, J. V.: Technika. 52 p., ISSN 2351-5384, ISBN 978-609-457-641-6. VGTU kodas 2233-M.

26. Konstantinas Jakovlevas-Mateckis. Bibliografinè rodyklè. Habilituoti daktarai. Sudarè Juršaitè, 0. V.: Technika. 210 p., ISSN 2351-5384, ISBN 978-609-457-629-4. VGTU kodas 2230-M.

27. Algirdas Vaclovas Valiulis. Bibliografinè rodyklè. Habilituoti daktarai. Sudarè Juršaitè, O., Striogienė, A. V.: Technika. 204 p., ISSN 2351-5384, ISBN 978-609-457-610-2. VGTU kodas 2219-M.

28. Akademikas Edmundas Kazimieras ZAVADSKAS. Bibliografinè rodyklè. Habilituoti daktarai. Sudarė Tamošaitienė, J.; Juršaitė, O. V.: Technika. 174 p., ISSN 2351-5384, ISBN 978-609-457-685-0. VGTU kodas 2255-M.

\section{Periodiniai mokslo žurnalai}

29. Aviation, Vol 18, No 1-4, p. 1-216. ISSN 1648-7788 print / ISSN 1822-4180 online.

30. Geodesy and Cartography, Vol 40, No 1-4, p. 1-180. ISSN 2029-6991 print / ISSN 2029-7009 online.

31. International Journal of Strategic Property Management, Vol 18, No 1-4, p. 1-406. ISSN 1648-715X print / ISSN 1648-9179 online.

32. Journal of Business Economics and Management, Vol 15, No 1-5, p. 1-1077. ISSN 1611-1699 / ISSN $2029-4433$ online.

33. Journal of Civil Engineering and Management, Vol 20, No 1-6, p. 1-898. ISSN 1392-3730 print / ISSN 1822-3605 online.

34. Journal of Environmental Engineering and Landscape Management, Vol 22, No 1-4, p. 1-318. ISSN 1648-6897 print / ISSN 18224199 online.

35. Creativity Studies, Vol 7, No 1-2, p. 1-134. ISSN 2345-0479 print / ISSN 2345-0487 online.

36. Mathematical Modelling and Analysis, Vol 19, No 1-5, p. 1-717. ISSN 1392-6292 print / ISSN $1648-3510$ online.

37. Mokslas - Lietuvos ateitis, 6 t., Nr. 1-6, p. 1-718. ISSN 2029-2341 print / ISSN 2029-2252 online.

38. Coactivity: Philosophy, Communication / Santalka: Filosofija, Komunikacija, 22 t., Nr. 1-2, p. 1-166. ISSN 2029-6320 print / ISSN 2029-6339 online.

39. Coactivity: Philology, Educology / Santalka: Filologija, Edukologija, 22 t., Nr. 1-2, p. 1-154. ISSN 2351-714X print / ISSN 2335-7711 online.

40. Engineering Structures and Technologies, Vol 6, No 1-4, p. 1-149. ISSN 2029-882X print / ISSN 2029-8838 online.

41. Technological and Economic Development of Economy, Vol 20, No 1-4, p. 1-800. ISSN 2029-4913 print / ISSN $2029-4921$ online.

42. The Baltic Journal of Road and Bridge Engineering, Vol 9, No 1-4, p. 1-340. ISSN 1822-427X print / ISSN 1822-4288 online.

43. Transport, Vol 29, No 1-4, p. 5-466. ISSN 1648-4142 print / ISSN 1648-3480 online.

44. Journal of Architecture and Urbanism, Vol 38, No 1-4, p. 1-305. ISSN 2029-7955 print / ISSN $2029-7947$ online.

45. Verslas: teorija ir praktika, 15 t., Nr. 1-4, p. 1-407. ISSN 1648-0627 print / ISSN 1822-4202 online.

46. Business, Management and Education, Vol 12, No 1-2, p. 1-332. ISSN 2029-7491 print / ISSN $2029-6169$ online.

\section{Konferencijų straipsnių rinkiniai}

47. 17-osios Lietuvos jaunuju mokslininku konferencijos „Mokslas - Lietuvos ateitis“ 2014 metu teminės konferencijos „PASTATU INŽlNERINĖS SISTEMOS“ (2013 m. balandžio 25-26 d.) straipsnių rinkinys. V.: Technika. 110 p., ISSN 2029-7157, elSSN 2029-7149; ISBN 978-609-457-648-5, eISBN 978-609-457-647-8. VGTU kodas 2240-M.

48. 17-tosios Lietuvos jaunujų mokslininkų konferencijos „Mokslas - Lietuvos ateitis“ 2014 metų teminės konferencijos „STATYBA“ (2014 m. kovo 19 - kovo 29 d.) straipsnių rinkinys. V.: Technika. 224 p. eISSN 2029-7149, eISBN 978-609-457-694-2. VGTU kodas 2256-M.

49. 17-tosios Lietuvos jaunujų mokslininkų konferencijos „Mokslas - Lietuvos ateitis“ 2014 metų teminės konferencijos „TRANSPORTO INŽINERIJA IR VADYBA“ (2014 m. gegužès 8 d.) straipsnių rinkinys. V.: Technika. 310 p. ISSN 2029-7157, elSSN 2029-7149; ISBN 978-609-457-714-7, elSBN 978-609-457-713-0. VGTU kodas 2267-M.

50. 8th International Scientific Conference "Business and Management 2014". Selected papers Volume 1. V.: Technika. 430 p. ISSN 2029-4441/eISSN 2029-929X, ISBN 978-609-457-650-8, eISBN 978-609-457-649-2. VGTU kodas 2238-M.

51. 8th International Scientific Conference “Business and Management 2014". Selected papers. Volume 2. V.: Technika. 510 p. ISSN 2029-4441 print/ 2029-929X online, ISBN 978-609-457-116-9; VGTU kodas 2239-M.

52. 9th International Conference “Environmental Engineering”. Selected papers. V.: Technika. 1949 p. elSSN 2029-7092, elSBN 978-609457-640-9, CD ISBN 978-609-457-690-4. VGTU kodas 2232-M.

53. International Conference "Mathematical modelling and analysis". Abstracts. V.: Technika. 86 p. elSSN 2351-5740, ISBN 978-609-457-692-8, eISBN 978-609-457-691-1; VGTU kodas 2246-M.

54. International Conference “Acoustic Climate Inside and Outside Buildings”. Abstracts. V.: Technika. 50 p. elSBN 978-609-457-704-8; VGTU kodas 2264-M.

\section{Vadovèliai}

55. Heidegger, M. Būtis ir laikas: vadovèlis. Vertèjas Kačerauskas, T. V.: Technika. 424 p., ISBN 978-609-457-619-5. VGTU kodas 1489-S.

56. Jaržemskis, A.; Jaržemskis, V. Krovininis transportas: vadovèlis. V.: Technika. 264 p., ISBN 978-609-457-586-0, elSBN 978-609-457-585-3; doi:10.3846/1486-S. VGTU kodas 1486-S.

57. Juodis, E. S.; Motuzienè, V. Vèdinimo aerodinamika: vadovèlis. V.: Technika. 296 p., ISBN 978-609-457-431-3, elSBN 978-609-457-341-5; doi:10.3846/1487-S. VGTU kodas 1487-S.

58. Kerienè, J. Chemija: vadovèlis. V.: Technika. 364 p., ISBN 978-609-457-665-2, elSBN 978-609-457-664-5; doi:10.3846/1504-S. VGTU kodas 1504-S

59. Kutut, V. Paveldo statinių tvarkybos technologijos: vadovèlis. V.: Technika. 448 p., ISBN 978-609-457-661-4, elSBN 978-609-457-660-7; doi:10.3846/1503-S. VGTU kodas 1503-S

60. Leonovič, I.; Laurinavičius, A.; Čygas, D. Keliai ir klimatas: vadovèlis. V.: Technika. 168 p., ISBN 978-609-457-355-2, elSBN 978-609457-354-5; doi:10.3846/1418-S. VGTU kodas 1418-S. 
61. Mackevičius, R. Geotechnikos darbų technologijos: vadovèlis. V.: Technika. 128 p., elSBN 978-609-457-689-8; doi:10.3846/1512-S. VGTU kodas 1512-S.

62. Marčiukaitis, G. Itemptojo gelžbetonio technologijos ir projektavimo pagrindai: vadovèlis. V.: Technika. 272 p., ISBN 978-609-457-659-1, eISBN 978-609-457-658-4; doi:10.3846/1501-S. VGTU kodas 1501-S.

63. Martinaitis, V.; Lukoševičius, V. Šilumos gamyba deginant kurą: vadovèlis. V.: Technika. 232 p., ISBN 978-609-457-633-1, elSBN 978609-457-632-4; doi:10.3846/1497-S. VGTU kodas 1497-S.

64. Melnikas, B. Tarptautinis verslas: inovacijos ir žinių ekonomikos kūrimas: vadovèlis. V.: Technika. 464 p., ISBN 978-609-457-457-3, eISBN 978-609-457-456-6; doi:10.3846/1484-S. VGTU kodas 1484-S.

65. Melnikas, B.; Jakubavičius, A.; Strazdas, R.; Chlivickas, E.; Lobanova, L.; Stankevičienè, J. Intelektinis verslas: vadovèlis. V.: Technika. 456 p., ISBN 978-609-457-635-5, eISBN 978-609-457-634-8; doi:10.3846/1498-S. VGTU kodas 1498-S.

66. Nagrockienè, R.; Skripkiūnas, G. Statybinių medžiagų technologiniai procesai ir ịranga: vadovèlis. V.: Technika. 224 p., ISBN 978-609457-512-9, eISBN 978-609-457-515-0; doi:10.3846/1480-S. VGTU kodas 1480-S.

67. Puzienè, R.; Stanionis, A. Nekilnojamojo turto administravimas Lietuvoje: vadovèlis. V.: Technika. 340 p., ISBN 978-609-457-728-4, eISBN 978-609-457-727-7; doi:10.3846/1519-S. VGTU kodas 1519-S.

68. Rusko, T.; Skorupa, P. English for Entertainment Industry: vadovèlis. V.: Technika. 232 p., ISBN 978-609-457-759-8, elSBN 978-609457-758-1; doi:10.3846/1522-S. VGTU kodas 1522-S.

69. Valiulis, A. V. A History of Materials and Technologies Development: vadovèlis. V.: Technika. 444 p., ISBN 978-609-457-740-6, elSBN 978609-457-674-4; doi:10.3846/1502-S. VGTU kodas 1502-S.

\section{Mokomieji metodiniai leidiniai}

70. Bagdžiūnaitè, R. Kartografiniai vaizdavimo būdai ir žemėlapių sudarymas: mokomoji knyga. V.: Technika. 100 p., ISBN 978-609-457-751-2, eISBN 978-609-457-513-6; doi:10.3846/1479-S. VGTU kodas 1479-S.

71. Baušys, R.; Kriukovas, A.; Rakauskas, T. Internetinių puslapių programavimas. DOM technologija: mokomoji knyga. V.: Technika. 160 p., ISBN 978-609-457-742-0, eISBN 978-609-457-670-6; doi:10.3846/1510-S. VGTU kodas 1510-S.

72. Bolutienè, V. Ivadas i taršos prevenciją: mokomoji knyga. V.: Technika. 148 p., elSBN 978-609-457-622-5; doi:10.3846/1491-S. VGTU kodas 1491-S.

73. Gailienè, I. Geležinkelių valdymas ir eismo organizavimas: mokomoji knyga. V.: Technika. 168 p., ISBN 978-609-457-631-7, elSBN 978609-457-630-0; doi:10.3846/1496-S. VGTU kodas 1496-S.

74. Gailius, A.; Girnienè, I. Materials Science: mokomoji knyga. V.: Technika. 138 p., elSBN 978-609-457-643-0; doi:10.3846/1500-S. VGTU kodas 1500-S.

75. Grubliauskas, R. Aplinkos monitoringas: mokomoji knyga. V.: Technika. 92 p., ISBN 978-609-457-657-7, elSBN 978-609-457-628-7; doi:10.3846/1495-S. VGTU kodas 1495-S.

76. Ivonis, E. Dinaminių sistemų optimizavimas: mokomoji knyga. V.: Technika. 103 p., elSBN 978-609-457-696-6; doi:10.3846/1515-S. VGTU kodas 1515-S.

77. Jakubavičius, A.; Strazdienè, G.; Vilys, M.; Burinskienè, A.; Žemaitis, E.; Pipirienè, V. Žiniomis gristas verslas: mokomoji knyga. V.: Technika. 220 p., elSBN 978-609-457-695-9; doi:10.3846/1513-S. VGTU kodas 1513-S.

78. Kvedaras, A. K.; Šapalas, A.; Šaučiuvėnas, G.; Blaževičius, Ž. Platus. plieninių konstrukcijų tvermès norminimas. LVS3. Pagrindžiamasis dokumentas: mokomoji knyga. V.: Technika. 94 p., ISBN 978-609-457-745-1, elSBN 978-609-457-744-4; doi:10.3846/1520-S. VGTU kodas 1520-S.

79. Kvedaras, A. K.; Šapalas, A.; Šaučiuvėnas, G.; Blaževičius, Ž. Platus plieninių konstrukcijų tvermės norminimas. LVS3. Projektavimo vadovas: mokomoji knyga. V.: Technika. 132 p., ISBN 978-609-457-747-5, eISBN 978-609-457-746-8; doi:10.3846/1521-S. VGTU kodas 1521-S.

80. Miščenko, O. Meet English Language Technical Terms: mokomoji knyga. V.: Technika. 176 p., ISBN 978-609-457-604-1, elSBN 978-609457-603-4; doi:10.3846/1488-S. VGTU kodas 1488-S.

81. Peleckienė, V. Besimokanti organizacija: teorija ir praktika: mokomoji knyga. V.: Technika. 168 p., ISBN 978-609-457-698-0, eISBN 978-609-457-697-3; doi:10.3846/1514-S. VGTU kodas 1514-S.

82. Podagèlis, I.; Laurinavičius, A.; Gailienè, I. Kelio, kelio statinių, žemės sankasos priežiūros ir remonto darbų saugos ir sveikatos technologinių kortelių aprašas: mokomoji knyga. V.: Technika. 436 p., ISBN 978-609-457-623-2. VGTU kodas 1492-S.

83. Savickas, A. Aviacinè elektronika: mokomoji knyga. V.: Technika. 408 p., ISBN 978-609-457-461-0, elSBN 978-609-457-460-3; doi:10.3846/1485-S. VGTU kodas 1485-S.

84. Špakauskas, V.; Grigaliūnaitè-Vonsevičienè, G. Fizikos uždavinynas. Elektromagnetizmas ir modernioji fizika: mokomoji knyga. V.: Technika. 150 p., elSBN 978-609-457-672-0; doi:10.3846/1507-S. VGTU kodas 1507-S.

85. Stankiuvienè, A. Teisiniai darbuotojų saugos ir sveikatos pagrindai: mokomoji knyga. V.: Technika. 90 p., ISBN 978-609-457-707-9, eISBN 978-609-457-626-3; doi:10.3846/1494-S. VGTU kodas 1494-S.

86. Zalieckienè, E. Degimo procesu teoriniai pagrindai ir uždaviniai: mokomoji knyga. V.: Technika. 136 p., ISBN 978-609-457-639-3, eISBN 978-609-457-638-6; doi:10.3846/1499-S. VGTU kodas1499-S.

87. Žegūnienė, N. O. Anglų-lietuvių kalbų aviacijos terminų žodynas / English-Lithuanian dictionary of aviation: mokomoji knyga. V.: Technika. 120 p., ISBN 978-609-457-625-6, eISBN 978-609-457-624-9; doi:10.3846/1493-S. VGTU kodas 1493-S.

88. Žiūrienė, R.; Pankrašovaitė, I.; Stančius, A. Rastrinės ir vektorinės grafikos valdymas: mokomoji knyga. V.: Technika. 176 p., eISBN 978-609-457-673-7; doi:10.3846/1506-S. VGTU kodas 1506-S.

\section{Daktaro disertacijos ir jų santraukos}

89. Augustinavičius, G. Mikropozicionavimo sistemų taikant lanksčias jungtis tyrimai. Daktaro disertacija. V.: Technika. 128 p., 20 egz. ISBN 2303-M.

90. Augustinavičius, G. Research of a Flexure Based Micropositioning Systems. Summary of Doctoral Dissertation. . V.: Technika. 24 p., 70 egz. VGTU kodas 2304-M. 
91. Bagočius, V. Kompleksinis statinių jūros aplinkoje racionalumo pagrindimas. Daktaro disertacija ir santrauka. V.: Technika. 158 p., 20 egz. ISBN 978-609-457-736-9. VGTU kodas 2275-M.

92. Bartkienè, L. Intelektualaus darbo našumo valdymas taikant biometrines technologijas. Daktaro disertacija. V.: Technika. 156 p., 20 egz. ISBN 978-609-457-743-7. VGTU kodas 2298-M.

93. Bartkienè, L. Productivity Management of Intellectual Work Using Biometric Technologies. Summary of Doctoral Dissertation. V.: Technika. 24 p., 70 egz. VGTU kodas 2299-M.

94. Birvydienè, R. Sunkio lauko nevienalytiškumo tyrimų metodikos tobulinimas. Daktaro disertacija ir santrauka. V.: Technika. 160 p., 20 egz. ISBN 978-609-457-735-2. VGTU kodas 2288-M.

95. Bratčikovienè, N. Šalies ekonomikos indikatorių dinamikos modelis. Daktaro disertacija ir santrauka. V.: Technika. 146 p., 20 egz. ISBN 978-609-457-618-8. VGTU kodas 2228-M.

96. Bruzgè, Š. Valstybinio subsidijavimo jtakos verslui vertinimas. Daktaro disertacija ir santrauka. V.: Technika. 152 p., 20 egz. ISBN 978-609-457-675-1. VGTU kodas 2244-M.

97. Cidzikienè, V. Radionuklidų sklaidos tyrimai ir vertinimas planuojamos atominès elektrinès aplinkoje. Daktaro disertacija ir santrauka. V.: Technika. 206 p., 20 egz. ISBN 978-609-457-741-3. VGTU kodas 2292-M.

98. Demidova-Buizinienè, I. Kompozicinio deflokulianto poveikis ugniai atsparaus betono struktūrai ir savybėms. Daktaro disertacija ir santrauka. V.: Technika. 120 p., 20 egz. ISBN 978-609-457-737-6. VGTU kodas 2291-M.

99. Gedminaitè-Raudonè, Ž. Regionų unikalumo ekonominis vertinimas Europos integracijos procesų kontekste. Daktaro disertacija ir santrauka. V.: Technika. 192 p., 20 egz. ISBN 978-609-457-687-4. VGTU kodas 2249-M.

100. Grainys, A. Microsecond High Magnetic Field Shaped Pulse Generators Research. Doctoral Dissertation. V.: Technika. 124 p., 20 egz. ISBN 978-609-457-684-3. VGTU kodas 2254-M.

101. Greičiūnè, L. Ivairiarūšių krovinių maršrutų žaliajame transporto koridoriuje tyrimas. Daktaro disertacija ir santrauka. V.: Technika. 134 p., 20 egz. ISBN 978-609-457-756-7. VGTU kodas 2305-M.

102. Grigalis, T. Structured Data Extraction From Template-Generated Web Pages. Doctoral Dissertation. V.: Technika. 138 p., 20 egz. ISBN 978-609-457-699-7. VGTU kodas 2262-M.

103. Grigoravičius, A. Nanometrinès skyros mikrorobotų pjezoketiklių skaitinis tyrimas. Daktaro disertacija ir santrauka. V.: Technika. 158 p., 20 egz. ISBN 978-609-457-718-5. VGTU kodas 2263-M.

104. Gudienè, N. Statybos projektu igyvendinimą lemiančių sėkmės veiksnių daugiakriterè analizė. Daktaro disertacija ir santrauka. V.: Technika. 156 p., 20 egz. ISBN 978-609-457-724-6. VGTU kodas 2276-M.

105. Gudonis, E. Trumpalaike ir ilgalaike apkrova veikiamų tempiamuju gelžbetoninių elementų deformacijų eksperimentiniai tyrimai ir modeliavimas. Daktaro disertacija ir santrauka. V.: Technika. 146 p., 20 egz. ISBN 978-609-457-739-0. VGTU kodas 2290-M.

106. Gulbinovič, L. Informacinių sistemu saugumo tyrimas ir išliekamumo vertinimo modelio sukūrimas. Daktaro disertacija ir santrauka. V.: Technika. 122 p., 20 egz. ISBN 978-609-457-733-8. VGTU kodas 2285-M.

107. Guobys, R. Sluoksniuotuju konstrukciju tyrimas gaisro sąlygomis. Daktaro disertacija. V.: Technika. 152 p., 20 egz. ISBN 978-609-457679-9. VGTU kodas 2247-M.

108. Guobys, R. Investigation of Multilayer Structures in Fire. Summary of Doctoral Dissertation. V.: Technika. 24 p., 70 egz. VGTU kodas 2248-M.

109. Kildienè, S. Statybos technologijų tvarios plètros daugiapakopis vertinimas. Daktaro disertacija ir santrauka. V.: Technika. 150 p., 20 egz. ISBN 978-609-457-702-4. VGTU kodas 2257-M.

110. Kirjanova, A. Buitiniu nuoteku individualaus valymo technologijos tyrimai ir sukūrimas. Daktaro disertacija ir santrauka. V.: Technika. 184 p., 20 egz. ISBN 978-609-457-755-0. VGTU kodas 2307-M.

111. Kisežauskienè, L. Exploring the Possibility to Assess and Reduce the Risk Due to Hazardous Materials Transportation by Deploying Roadside Safety Barriers. Doctoral Dissertation. V.: Technika. 184 p., 20 egz. ISBN 978-609-457-721-5. VGTU kodas 2279-M.

112. Kundrotas, B. Šešiafazių asinchroninių variklių pereinamuju vyksmų tyrimas. Daktaro disertacija ir santrauka. V.: Technika. 134 p., 20 egz. ISBN 978-609-457-682-9. VGTU kodas 2250-M.

113. Lapinskienè, G. The Evaluation of the Impact of Economic Growth on Greenhouse Gas Emissions. Doctoral Dissertation. V.: Technika. 142 p., 20 egz. ISBN 978-609-457-700-0. VGTU kodas 2259-M.

114. Lapinskienè, G. Ekonomikos augimo ịtakos šiltnamio efektą sukeliančių dujų kiekiui vertinimas. Daktaro disertacijos santrauka. V.: Technika. 24 p., 70 egz. VGTU kodas 2260-M.

115. Lavcel-Budko, O. Netiesinių bangų rezonansinès sąveikos matematinių modelių tyrimas. Daktaro disertacija. V.: Technika. 114 p., 20 egz. ISBN 978-609-457-723-9. VGTU kodas 2281-M.

116. Lavcel-Budko, O. The Investigation of Resonant Interaction of Some Mathematical Model of Nonlinear Waves. Summary of Doctoral Dissertation. V.: Technika. 24 p., 70 egz. VGTU kodas 2282-M.

117. Medineckienè, M. Fuzzy Multi-Criteria Assessment of Dwelling's Sustainability. Doctoral Dissertation. V.: Technika. 104 p., 20 egz. ISBN 978-609-457-654-6. VGTU kodas 2235-M.

118. Medineckienè, M. Neapibrěžtas daugiakriterinis būstu tvarumo vertinimas. Daktaro disertacijos santrauka. V.: Technika. 24 p., 70 egz. VGTU kodas 2236-M.

119. Metlevskis, E. Plačiajuosčių planariujų lètinimo sistemų modeliai ir jų tyrimas. Daktaro disertacija ir santrauka. V.: Technika. 136 p., 20 egz. ISBN 978-609-457-683-6. VGTU kodas 2253-M.

120. Mikučionienè, R. Model of Sustainable Management of Building Energy Perfomance. Summary of Doctoral Dissertation. V.: Technika. 24 p., 70 egz. VGTU kodas 2274-M.

121. Mikučionienè, R. Pastato energinių savybių darnaus valdymo modelis. Daktaro disertacija. V.: Technika. 100 p., 20 egz. ISBN 978-609457-716-1. VGTU kodas 2273-M.

122. Mikučionis, Š. Modelling of Stratified Dielectric Medium Stripline Delay Devices. Doctoral Dissertation. V.: Technika. 134 p., 20 egz. ISBN 978-609-457-750-5. VGTU kodas 2302-M.

123. Nugaras, J. Assessment of Networking of Higher Education Institution. Daktaro disertacija ir santrauka. V.: Technika. 124 p., 20 egz. ISBN 978-609-457-749-9. VGTU kodas 2295-M.

124. Palevičius, V. Lengvuju automobiliu stovejjimo aikšteliu mieste vertinimas daugiatiksliais metodais. Daktaro disertacija ir santrauka. V.: Technika. 178 p., 20 egz. ISBN 978-609-457-725-3. VGTU kodas 2269-M. 
125. Paliukaitè, M. Bitumo savybių kitimo j̇taka asfalto dangos funkcionavimui. Daktaro disertacija ir santrauka. V.: Technika. 166 p., 20 egz. ISBN 978-609-457-701-7. VGTU kodas 2258-M.

126. Papšienè, L. Erdvinès informacijos modeliavimo ir harmonizavimo tobulinimas skaitmeninejje kartografijoje. Daktaro disertacija ir santrauka. V.: Technika. 178 p., 20 egz. ISBN 978-609-457-734-5. VGTU kodas 2289-M.

127. Pilkavičius, S. Armatūros ir betono sankibos mechaninès elgsenos tempiant modeliavimas. Daktaro disertacija ir santrauka. V.: Technika. 156 p., 20 egz. ISBN 978-609-457-715-4. VGTU kodas 2268-M.

128. Platakis, A. Fotovoltinių keitiklių tiekiamos energijos kokybės tyrimas ir gerinimas. Daktaro disertacija ir santrauka. V.: Technika. 134 p., 20 egz. ISBN 978-609-457-681-2. VGTU kodas 2252-M.

129. Plonis, D. Girotropiniu įtaisų modelių tyrimas ir taikymas. Daktaro disertacija ir santrauka. V.: Technika. 158 p., 20 egz. ISBN $978-609-$ 457-676-8. VGTU kodas 2245-M.

130. Popov, M. Tamprių plastinių geometriškai netiesinių strypinių konstrukcijų optimizavimas ribojant poslinkius. Daktaro disertacija ir santrauka. V.: Technika. 134 p., 20 egz. ISBN 978-609-457-686-7. VGTU kodas 2251-M.

131. Rimša, V. Daleliu kompozito diskretusis modelis. Daktaro disertacija ir santrauka. V.: Technika. 124 p., 20 egz. ISBN 978-609-457-703-1. VGTU kodas 2261-M.

132. Rudzkis, P. Investiciju atsinaujinančių išteklių energetiką rizikos vertinimas. Daktaro disertacija ir santrauka. V.: Technika. 152 p., 20 egz. ISBN 978-609-457-726-0. VGTU kodas 2283-M.

133. Sabaitis, D. Apskritiminių rastrinių skalių kompaktinėje laikmenoje tyrimas. Daktaro disertacija. V.: Technika. 114 p., 20 egz. ISBN 978-609-457-753-6. VGTU kodas 2296-M.

134. Sabaitis, D. Research of Circular Raster Scales in Compact Disk. Summary of Doctoral Dissertation. V.: Technika. 24 p., 70 egz. VGTU kodas 2297-M.

135. Skrickij, V. Transporto mašinų transmisijos elementų dinaminių procesų tyrimas. Daktaro disertacija ir santrauka. V.: Technika. 126 p., 20 egz. ISBN 978-609-457-731-4. VGTU kodas 2270-M.

136. Stasiukynas, A. Rekreacinių kompleksų darnios plètros vertinimas. Daktaro disertacija ir santrauka. V.: Technika. 134 p., 20 egz. ISBN 978-609-457-738-3. VGTU kodas 2277-M.

137. Sviderske, T. Country Risk Assessment in Economic Security and Sustainability Context. Daktaro disertacija ir santrauka. V.: Technika. 132 p., 20 egz. ISBN 978-609-457-760-4. VGTU kodas 2308-M.

138. Šiaudinytė, L. Research and Development of Methods and Instrumentation for the Calibration of Vertical Angle Measuring Systems of Geodetic Instruments. Doctoral Dissertation. V.: Technika. 134 p., 20 egz. ISBN 978-609-457-712-3. VGTU kodas 2266-M.

139. Šimelytè, A. Tiesioginių užsienio investiciju politikos formavimas Baltijos šalyse. Daktaro disertacija ir santrauka. V.: Technika. 184 p., 20 egz. ISBN 978-609-457-678-2. VGTU kodas 2237-M.

140. Šiožinytė, E. Šiandieninių statybos normų ir tradicijos derinimas etninės architektūros pastatuose. Daktaro disertacija. V.: Technika. 120 p., 20 egz. ISBN 978-609-457-732-1. VGTU kodas 2286-M.

141. Šiožinytè, E. Consistency Between Contemporary Building Norms and Tradition in Vernacular Buildings. Summary of Doctoral Dissertation. V.: Technika. 24 p., 70 egz. VGTU kodas 2287-M.

142. Ulitinas, T. Sferinio kevalo optimizavimas prisitaikomumo sąlygomis. Daktaro disertacija ir santrauka. V.: Technika. 128 p., 20 egz. ISBN 978-609-457-757-4. VGTU kodas 2306-M.

143. Vilkaitè-Vaitonè, N. Paslaugų vartotoju lojalumo vertinimas. Daktaro disertacija. V.: Technika. 114 p., 20 egz. ISBN 978-609-457-754-3. VGTU kodas 2293-M.

144. Vilkaitė-Vaitonè, N. Service Customers' Loyalty Measurement. Summary of Doctoral Dissertation. V.: Technika. 24 p., 70 egz. VGTU kodas 2294-M.

145. Volvačiovas, R. Visuomeninès paskirties pastatu atnaujinimo efektyvumo tyrimas ir daugiatikslis vertinimas. Daktaro disertacija ir santrauka. V.: Technika. 172 p., 20 egz. ISBN 978-609-457-653-9. VGTU kodas 2234-M.

146. Žaglinskis, J. Dyzelinių variklių, dirbančių antros kartos biodegalų mišiniais, eksploatacinių charakteristikų tyrimai. Daktaro disertacija ir santrauka. V.: Technika. 182 p., 20 egz. ISBN 978-609-457-722-2. VGTU kodas 2280-M.

147. Žèkas, V. Sklypo atsinaujinančius energijos išteklius naudojančių technologiju atrankos metodas. Daktaro disertacija ir santrauka. V.: Technika. 146 p., 20 egz. ISBN 978-609-457-717-8. VGTU kodas 2271-M. 
VGTU profesoriai (2014 1231 duomenys)

\begin{tabular}{|c|c|c|c|c|c|c|c|}
\hline $\begin{array}{l}\text { Eil. } \\
\text { Nr. }\end{array}$ & Vardas & Pavardè & Pareigos & $\begin{array}{l}\text { Pareigų } \\
\text { tipas }\end{array}$ & $\begin{array}{l}\text { Mokslo } \\
\text { laipsnis }\end{array}$ & $\begin{array}{l}\text { Pedagoginis } \\
\text { vardas }\end{array}$ & Padalinys \\
\hline 1 & $\begin{array}{l}\text { Vladislovas } \\
\text { Česlovas }\end{array}$ & Aksamitauskas & profesorius & pagrindinès & dr. & doc. & Geodezijos ir kadastro katedra \\
\hline 2 & Jurgita & Antuchevičienè & profesorius & pagrindinès & dr. & doc. & $\begin{array}{l}\text { Statybos technologijos ir vadybos } \\
\text { katedra }\end{array}$ \\
\hline 3 & Jonas & Anuškevičius & profesorius & pagrindinès & & prof. & Dailès katedra \\
\hline 4 & Juozas & Atkočiūnas & profesorius & pagrindinès & habil. dr. & prof. & Statybinės mechanikos katedra \\
\hline 5 & Darius & Bačinskas & profesorius & pagrindinès & dr. & doc. & Tiltų ir specialiuju statinių katedra \\
\hline 6 & Saulius & Balevičius & profesorius & antraeilès & habil. dr. & prof. & Elektrotechnikos katedra \\
\hline 7 & Edita & Baltrènaitè & profesorius & pagrindinès & dr. & doc. & Aplinkos apsaugos katedra \\
\hline 8 & Pranas & Baltrènas & profesorius & pagrindinès & habil. dr. & prof. & Aplinkos apsaugos katedra \\
\hline 9 & Audrius & Banaitis & profesorius & pagrindinès & dr. & doc. & $\begin{array}{l}\text { Statybos ekonomikos ir nekilnojamojo } \\
\text { turto vadybos katedra }\end{array}$ \\
\hline 10 & Algirdas & Baškys & profesorius & pagrindinès & $\mathrm{dr}$. & prof. & Kompiuterių inžinerijos katedra \\
\hline 11 & Nijolè & Batarlienè & profesorius & pagrindinès & dr. & doc. & $\begin{array}{l}\text { Logistikos ir transporto vadybos } \\
\text { katedra }\end{array}$ \\
\hline 12 & Romualdas & Baušys & profesorius & pagrindinès & habil. dr. & prof. & Grafinių sistemų katedra \\
\hline 13 & Rimantas & Belevičius & profesorius & pagrindinès & habil. dr. & prof. & Informacinių technologijų katedra \\
\hline 14 & Marijonas & Bogdevičius & profesorius & pagrindinès & habil. dr. & prof. & $\begin{array}{l}\text { Transporto technologinių įrenginių } \\
\text { katedra }\end{array}$ \\
\hline 15 & Vytautas & Bučinskas & profesorius & pagrindinès & dr. & doc. & Mechatronikos ir robotikos katedra \\
\hline 16 & Rimantas & Buivydas & profesorius & pagrindinès & dr. & prof. & $\begin{array}{l}\text { Architektūros pagrindų ir teorijos } \\
\text { katedra }\end{array}$ \\
\hline 17 & Gintautas & Bureika & profesorius & pagrindinès & $\mathrm{dr}$ & doc. & Geležinkelių transporto katedra \\
\hline 18 & Marija & Burinskienè & profesorius & pagrindinès & $\mathrm{dr}$ & prof. & Miestų statybos katedra \\
\hline 20 & Virginija & Chreptavičienè & profesorius & pagrindinès & dr. & doc. & $\begin{array}{l}\text { Kūrybos verslo ir komunikacijos } \\
\text { katedra }\end{array}$ \\
\hline 21 & Gintaras & Čaikauskas & profesorius & pagrindinès & & prof. & Architektūros katedra \\
\hline 22 & Antanas & Čenys & profesorius & pagrindinès & habil. dr. & prof. & Informacinių sistemų katedra \\
\hline 23 & Audrius & Čereška & profesorius & pagrindinès & dr. & prof. & Mechanikos inžinerijos katedra \\
\hline 24 & Sigitas & Čereškevičius & profesorius & pagrindinès & dr. & doc. & Urbanistikos katedra \\
\hline 25 & Jūratè & Černevičiūtè & profesorius & pagrindinès & dr. & doc. & $\begin{array}{l}\text { Kūrybos verslo ir komunikacijos } \\
\text { katedra }\end{array}$ \\
\hline 26 & Algimantas & Česnulevičius & profesorius & antraeilès & habil. dr. & prof. & Hidraulikos katedra \\
\hline 27 & Raimondas & Čiegis & profesorius & pagrindinès & habil. dr. & prof. & Matematinio modeliavimo katedra \\
\hline 28 & Donatas & Čygas & profesorius & pagrindinès & dr. & prof. & Kelių katedra \\
\hline 29 & Stanislavas & Dadelo & profesorius & pagrindinès & $\mathrm{dr}$ & doc. & Kūno kultūros katedra \\
\hline 30 & Alfonsas & Daniūnas & profesorius & pagrindinès & dr. & prof. & $\begin{array}{l}\text { Metalinių ir medinių konstrukciju } \\
\text { katedra }\end{array}$ \\
\hline 31 & Vida & Davidavičienè & profesorius & pagrindinès & $\mathrm{dr}$ & doc. & Verslo technologiju katedra \\
\hline 32 & Albinas & Gailius & profesorius & pagrindinès & $\mathrm{dr}$. & prof. & Statybinių medžiagų katedra \\
\hline 33 & Vidmantas & Gylikis & profesorius & pagrindinès & & doc. & Dailès katedra \\
\hline 34 & Romualdas & Ginevičius & profesorius & pagrindinès & habil. dr. & prof. & İmoniu ekonomikos ir vadybos katedra \\
\hline 35 & Aloyzas & Girgždys & profesorius & pagrindinès & dr. & prof. & Fizikos katedra \\
\hline 36 & Jonas & Gradauskas & profesorius & antraeilès & dr. & doc. & Fizikos katedra \\
\hline 37 & Saulius & Grigiškis & profesorius & antraeilès & dr. & & Chemijos ir bioinžinerijos katedra \\
\hline 38 & Vilija & Grincevičienè & profesorius & antraeilès & dr. & prof. & Filosofijos ir politologijos katedra \\
\hline 39 & Arūnas & Jakštas & profesorius & pagrindinès & dr. & doc. & Mechanikos inžinerijos katedra \\
\hline 40 & Artūras & Jakubavičius & profesorius & pagrindinès & dr. & doc. & $\begin{array}{l}\text { Tarptautinès ekonomikos ir vadybos } \\
\text { katedra }\end{array}$ \\
\hline
\end{tabular}




\begin{tabular}{|c|c|c|c|c|c|c|c|}
\hline $\begin{array}{l}\text { Eil. } \\
\text { Nr. }\end{array}$ & Vardas & Pavardè & Pareigos & $\begin{array}{l}\text { Pareigų } \\
\text { tipas }\end{array}$ & $\begin{array}{l}\text { Mokslo } \\
\text { laipsnis }\end{array}$ & $\begin{array}{l}\text { Pedagoginis } \\
\text { vardas }\end{array}$ & Padalinys \\
\hline 42 & Aldona & Jarašūnienè & profesorius & antraeilès & dr. & doc. & $\begin{array}{l}\text { Logistikos ir transporto vadybos } \\
\text { katedra }\end{array}$ \\
\hline 43 & Bronius & Jonaitis & profesorius & pagrindinès & $\mathrm{dr}$ & doc. & $\begin{array}{l}\text { Gelžbetoninių ir mūrinių konstrukciju } \\
\text { katedra }\end{array}$ \\
\hline 44 & Artūras & Jukna & profesorius & pagrindinès & dr. & prof. & Fizikos katedra \\
\hline 45 & Algirdas & Juozapaitis & profesorius & pagrindinès & dr. & prof. & Tiltų ir specialiujų statinių katedra \\
\hline 46 & Jūratè & Jurevičienè & profesorius & pagrindinès & dr. & doc. & $\begin{array}{l}\text { Architektūros pagrindų ir teorijos } \\
\text { katedra }\end{array}$ \\
\hline 47 & Daiva & Jurevičienè & profesorius & pagrindinès & dr. & doc. & Finansų inžinerijos katedra \\
\hline 48 & Mindaugas & Jurevičius & profesorius & pagrindinės & $\mathrm{dr}$. & prof. & Mechanikos inžinerijos katedra \\
\hline 49 & Arnas & Kačeniauskas & profesorius & pagrindinès & dr. & doc. & Grafinių sistemų katedra \\
\hline 50 & Tomas & Kačerauskas & profesorius & pagrindinės & dr. & prof. & Filosofijos ir politologijos katedra \\
\hline 51 & Rimantas & Kačianauskas & profesorius & pagrindinès & habil. dr. & prof. & $\begin{array}{l}\text { Medžiagu atsparumo ir teorinės } \\
\text { mechanikos katedra }\end{array}$ \\
\hline 52 & Algimantas & Kajackas & profesorius & pagrindinès & habil. dr. & prof. & Telekomunikacijų inžinerijos katedra \\
\hline 53 & Gintaris & Kaklauskas & profesorius & pagrindinès & habil. dr. & prof. & Tiltų ir specialiujų statinių katedra \\
\hline 54 & Artūras & Kaklauskas & profesorius & pagrindinès & habil. dr. & prof. & $\begin{array}{l}\text { Statybos ekonomikos ir nekilnojamojo } \\
\text { turto vadybos katedra }\end{array}$ \\
\hline 55 & Romanas & Karkauskas & profesorius & pagrindinès & dr. & prof. & Statybinės mechanikos katedra \\
\hline 56 & Albinas & Kasparaitis & profesorius & antraeilès & habil. dr. & prof. & Mechanikos inžinerijos katedra \\
\hline 57 & Jadvyga Regina & Kerienè & profesorius & pagrindinès & dr. & prof. & Chemijos ir bioinžinerijos katedra \\
\hline 58 & Jonas & Kleiza & profesorius & pagrindinès & $\mathrm{dr}$. & prof. & Matematinio modeliavimo katedra \\
\hline 59 & Romualdas & Kliukas & profesorius & pagrindinès & dr. & prof. & $\begin{array}{l}\text { Medžiagų atsparumo ir teorinės me- } \\
\text { chanikos katedra }\end{array}$ \\
\hline 60 & Danutè & Krapavickaitè & profesorius & pagrindinès & dr. & doc. & Matematinės statistikos katedra \\
\hline 61 & Algimantas & Krenevičius & profesorius & pagrindinès & dr. & prof. & $\begin{array}{l}\text { Medžiagu atsparumo ir teorinės } \\
\text { mechanikos katedra }\end{array}$ \\
\hline 62 & Aleksandras & Krylovas & profesorius & antraeilès & dr. & prof. & Matematinio modeliavimo katedra \\
\hline 63 & Kęstutis & Kubilius & profesorius & antraeilès & habil. dr. & prof. & Matematinės statistikos katedra \\
\hline 64 & Juozas & Kulys & profesorius & pagrindinès & habil. dr. & prof. & Chemijos ir bioinžinerijos katedra \\
\hline 65 & Genadijus & Kulvietis & profesorius & pagrindinès & habil. dr. & prof. & Informaciniu technologijų katedra \\
\hline 66 & Vygaudas & Kvedaras & profesorius & pagrindinès & dr. & prof. & Elektrotechnikos katedra \\
\hline 67 & Alfredas & Laurinavičius & profesorius & pagrindinès & dr. & prof. & Kelių katedra \\
\hline 68 & $\begin{array}{l}\text { Mindaugas } \\
\text { Kazimieras }\end{array}$ & Leonavičius & profesorius & pagrindinès & habil. dr. & prof. & $\begin{array}{l}\text { Medžiagų atsparumo ir teorinès } \\
\text { mechanikos katedra }\end{array}$ \\
\hline 69 & Kęstutis & Lupeikis & profesorius & pagrindinès & dr. & doc. & Architektūros katedra \\
\hline 70 & Romualdas & Mačiulaitis & profesorius & pagrindinès & habil. dr. & prof. & Statybinių medžiagų katedra \\
\hline 71 & Vacius & Mališauskas & profesorius & pagrindinès & dr. & doc. & Elektroninių sistemų katedra \\
\hline 72 & Andrejus Henrikas & Marcinkevičius & profesorius & pagrindinès & habil. dr. & prof. & Mechanikos inžinerijos katedra \\
\hline 73 & Romanas & Martavičius & profesorius & pagrindinès & habil. dr. & prof. & Elektroninių sistemų katedra \\
\hline 74 & Vytautas & Martinaitis & profesorius & pagrindinès & habil. dr. & prof. & Pastatų energetikos katedra \\
\hline 75 & Rimas & Maskeliūnas & profesorius & pagrindinès & dr. & prof. & Poligrafinių mašinų katedra \\
\hline 76 & Dalius & Mažeika & profesorius & pagrindinès & dr. & prof. & Informaciniu sistemų katedra \\
\hline 77 & Borisas & Melnikas & profesorius & pagrindinès & habil. dr. & prof. & $\begin{array}{l}\text { Tarptautinès ekonomikos ir vadybos } \\
\text { katedra }\end{array}$ \\
\hline 78 & Paulius & Miškinis & profesorius & pagrindinès & dr. & prof. & Fizikos katedra \\
\hline 79 & Sigitas & Mitkus & profesorius & pagrindinès & dr. & prof. & Teisės katedra \\
\hline 80 & Dalius & Navakauskas & profesorius & pagrindinès & $\mathrm{dr}$. & prof. & Elektroninių sistemų katedra \\
\hline 81 & Rūta & Navakauskienè & profesorius & antraeilès & $\mathrm{dr}$. & prof. & Chemijos ir bioinžinerijos katedra \\
\hline 82 & Romualdas & Navickas & profesorius & pagrindinès & habil. dr. & prof. & Kompiuterių inžinerijos katedra \\
\hline 83 & Liudmila & Nickelson & profesorius & antraeilès & habil. dr. & prof. & Elektroninių sistemų katedra \\
\hline 84 & Arnoldas & Norkus & profesorius & pagrindinès & $\mathrm{dr}$. & prof. & Geotechnikos katedra \\
\hline 85 & Jurij & Novickij & profesorius & pagrindinès & dr. & prof. & Elektrotechnikos katedra \\
\hline 86 & Rolandas & Palekas & profesorius & pagrindinès & & prof. & Architektūros katedra \\
\hline
\end{tabular}




\begin{tabular}{|c|c|c|c|c|c|c|c|}
\hline $\begin{array}{l}\text { Eil. } \\
\text { Nr. }\end{array}$ & Vardas & Pavardè & Pareigos & $\begin{array}{l}\text { Pareigu } \\
\text { tipas }\end{array}$ & $\begin{array}{l}\text { Mokslo } \\
\text { laipsnis }\end{array}$ & $\begin{array}{c}\text { Pedagoginis } \\
\text { vardas }\end{array}$ & Padalinys \\
\hline 87 & $\begin{array}{l}\text { Narimantas } \\
\text { Kazimieras }\end{array}$ & Paliulis & profesorius & pagrindinès & habil. dr. & prof. & Verslo technologiju katedra \\
\hline 88 & Ramūnas & Palšaitis & profesorius & pagrindinès & habil. dr. & prof. & $\begin{array}{l}\text { Logistikos ir transporto vadybos } \\
\text { katedra }\end{array}$ \\
\hline 89 & Josifas & Parasonis & profesorius & pagrindinès & habil. dr. & prof. & Architektūros inžinerijos katedra \\
\hline 90 & $\begin{array}{l}\text { Eimuntas } \\
\text { Kazimieras }\end{array}$ & Paršeliūnas & profesorius & pagrindinès & dr. & prof. & Geodezijos ir kadastro katedra \\
\hline 91 & Šarūnas & Paulikas & profesorius & pagrindinès & dr. & prof. & Telekomunikacijų inžinerijos katedra \\
\hline 92 & Kęstutis & Peleckis & profesorius & pagrindinès & $\mathrm{dr}$. & doc. & Imonių ekonomikos ir vadybos katedra \\
\hline 93 & Kazys & Petkevičius & profesorius & pagrindinès & dr. & prof. & Kelių katedra \\
\hline 94 & Petras & Petroškevičius & profesorius & pagrindinès & habil. dr. & prof. & Geodezijos ir kadastro katedra \\
\hline 95 & Valentinas & Podvezko & profesorius & pagrindinès & $\mathrm{dr}$. & prof. & Matematinės statistikos katedra \\
\hline 96 & Algimantas Juozas & Poška & profesorius & pagrindinès & habil. dr. & prof. & Automatikos katedra \\
\hline 97 & Olegas & Prentkovskis & profesorius & pagrindinès & dr. & doc. & $\begin{array}{l}\text { Transporto technologiniu irrenginių } \\
\text { katedra }\end{array}$ \\
\hline 98 & Valdas & Pruskus & profesorius & pagrindinès & habil. dr. & prof. & Filosofijos ir politologijos katedra \\
\hline 99 & Saugirdas & Pukalskas & profesorius & pagrindinès & dr. & doc. & Automobilių transporto katedra \\
\hline 100 & Ernesta & Račienè & profesorius & pagrindinès & dr. & prof. & Užsienio kalbų katedra \\
\hline 101 & Marijus & Radavičius & profesorius & antraeilès & dr. & doc. & Matematinės statistikos katedra \\
\hline 102 & Ona Gražina & Rakauskienè & profesorius & antraeilès & habil. dr. & prof. & $\begin{array}{l}\text { Tarptautinės ekonomikos ir vadybos } \\
\text { katedra }\end{array}$ \\
\hline 103 & Saulius & Raslanas & profesorius & pagrindinès & dr. & prof. & $\begin{array}{l}\text { Statybos ekonomikos ir nekilnojamojo } \\
\text { turto vadybos katedra }\end{array}$ \\
\hline 104 & Roma & Rinkevičienè & profesorius & pagrindinės & habil. dr. & prof. & Automatikos katedra \\
\hline 105 & Rimantas & Rudzkis & profesorius & antraeilès & habil. dr. & prof. & Matematinès statistikos katedra \\
\hline 106 & $\begin{array}{l}\text { Aleksandras } \\
\text { Vytautas }\end{array}$ & Rutkauskas & profesorius & pagrindinès & habil. dr. & prof. & Finansų inžinerijos katedra \\
\hline 107 & Leonidas & Sakalauskas & profesorius & antraeilès & habil. dr. & prof. & Informacinių technologijų katedra \\
\hline 108 & Almantas Liudas & Samalavičius & profesorius & pagrindinès & dr. & doc. & $\begin{array}{l}\text { Architektūros pagrindų ir teorijos } \\
\text { katedra }\end{array}$ \\
\hline 109 & Artūras & Serackis & profesorius & pagrindinès & dr. & doc. & Elektroninių sistemų katedra \\
\hline 110 & Jolanta & Sereikaitè & profesorius & pagrindinès & $\mathrm{dr}$. & doc. & Chemijos ir bioinžinerijos katedra \\
\hline 111 & Elena & Servienè & profesorius & antraeilès & $\mathrm{dr}$ & doc. & Chemijos ir bioinžinerijos katedra \\
\hline 112 & Donatas Jonas & Sidaravičius & profesorius & pagrindinès & dr. & prof. & Poligrafinių mašinų katedra \\
\hline 113 & Marijonas & Sinica & profesorius & pagrindinès & $\mathrm{dr}$. & & Statybinių medžiagų katedra \\
\hline 114 & Henrikas & Sivilevičius & profesorius & pagrindinès & habil. dr. & prof. & $\begin{array}{l}\text { Transporto technologiniu irenginių } \\
\text { katedra }\end{array}$ \\
\hline 115 & Gintautas & Skripkiūnas & profesorius & pagrindinès & dr. & doc. & Statybinių medžiagų katedra \\
\hline 116 & Rasa & Smaliukienè & profesorius & antraeilès & dr. & doc. & $\begin{array}{l}\text { Tarptautinės ekonomikos ir vadybos } \\
\text { katedra }\end{array}$ \\
\hline 117 & Edgar & Sokolovskij & profesorius & pagrindinès & dr. & doc. & Automobilių transporto katedra \\
\hline 118 & Bronislovas & Spruogis & profesorius & pagrindinès & habil. dr. & prof. & $\begin{array}{l}\text { Transporto technologiniu įrenginių } \\
\text { katedra }\end{array}$ \\
\hline 119 & Eugenijus Kęstutis & Staniūnas & profesorius & pagrindinès & dr. & doc. & Urbanistikos katedra \\
\hline 120 & Voitech & Stankevič & profesorius & antraeilès & $\mathrm{dr}$. & doc. & Elektrotechnikos katedra \\
\hline 121 & Jelena & Stankevičienè & profesorius & pagrindinès & $\mathrm{dr}$. & doc. & Finansų inžinerijos katedra \\
\hline 122 & Jonas & Stankūnas & profesorius & pagrindinès & habil. dr. & prof. & Aviacijos prietaisu katedra \\
\hline 123 & Gintaras & Stauskis & profesorius & pagrindinès & dr. & doc. & Urbanistikos katedra \\
\hline 124 & Gintaras & Stauskis & profesorius & pagrindinės & dr. & doc. & Urbanistikos katedra \\
\hline 125 & Rolandas & Strazdas & profesorius & pagrindinès & dr. & doc. & $\begin{array}{l}\text { Kūrybos verslo ir komunikacijos } \\
\text { katedra }\end{array}$ \\
\hline 126 & Jonas Kazys & Sunklodas & profesorius & antraeilès & habil. dr. & prof. & Matematinès statistikos katedra \\
\hline 127 & Algirdas & Sužiedèlis & profesorius & antraeilès & dr. & prof. & Fizikos katedra \\
\hline 128 & Antanas & Šapalas & profesorius & pagrindinès & dr. & prof. & $\begin{array}{l}\text { Metalinių ir medinių konstrukcijų } \\
\text { katedra }\end{array}$ \\
\hline 129 & Valentinas & Šaulys & profesorius & pagrindinès & dr. & prof. & Hidraulikos katedra \\
\hline
\end{tabular}




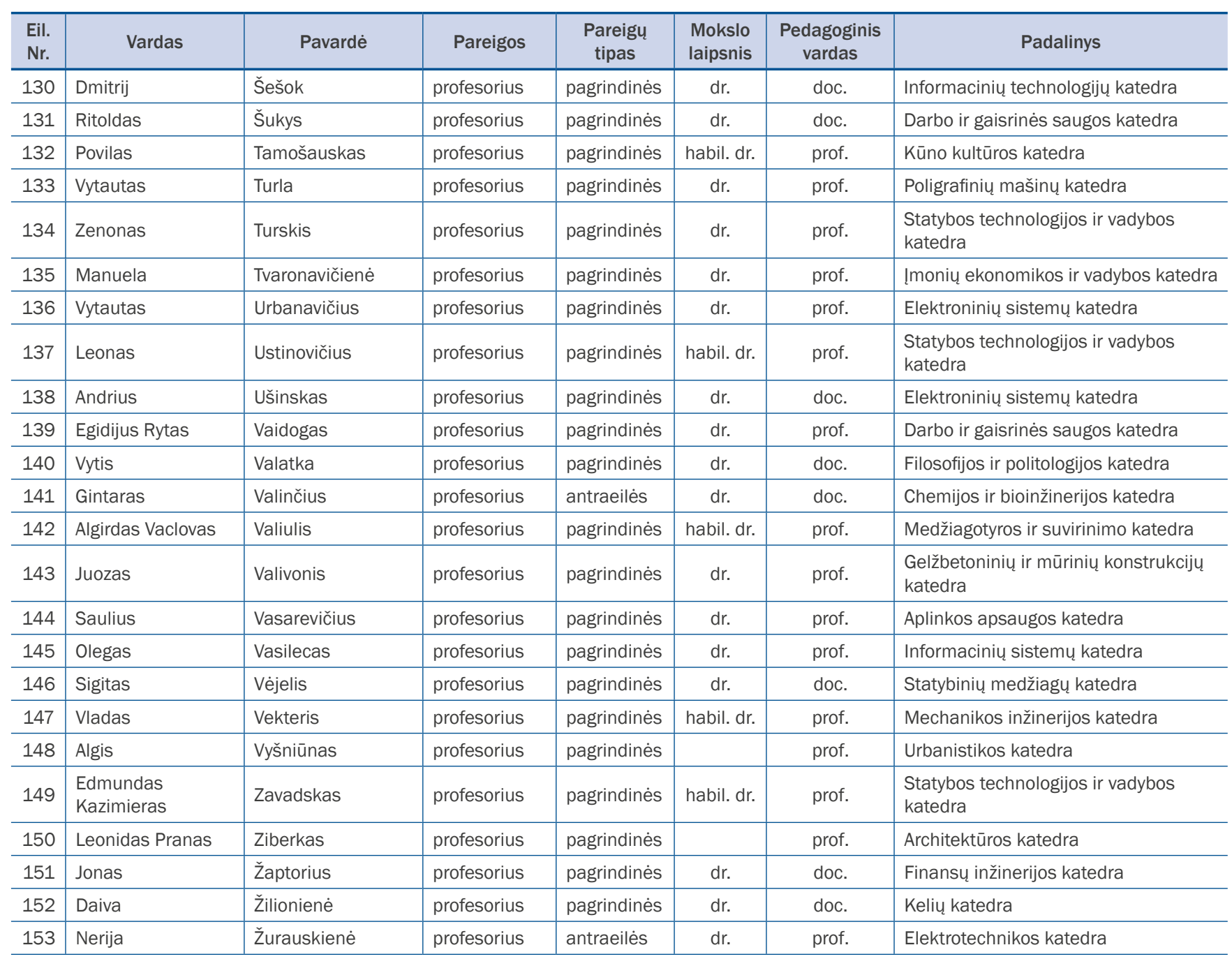


VGTU docentai (2014 1231 duomenys)

\begin{tabular}{|c|c|c|c|c|c|c|c|}
\hline $\begin{array}{l}\text { Eil. } \\
\text { Nr. }\end{array}$ & Vardas & Pavardè & Pareigos & $\begin{array}{l}\text { Pareigu } \\
\text { tipas }\end{array}$ & $\begin{array}{l}\text { Mokslo } \\
\text { laipsnis }\end{array}$ & $\begin{array}{l}\text { Pedagoginis } \\
\text { vardas }\end{array}$ & Padalinys \\
\hline 1 & Inesa & $\begin{array}{l}\text { Alistratovaitè- } \\
\text { Kurtinaitienè }\end{array}$ & docentas & pagrindinès & dr. & doc. & Urbanistikos katedra \\
\hline 2 & Gintautas & Ambrasas & docentas & pagrindinès & dr. & doc. & Statybos technologijos ir vadybos katedra \\
\hline 3 & Nikolaj & Ambrusevič & docentas & antraeilès & dr. & & Kūrybos verslo ir komunikacijos katedra \\
\hline 4 & Jonas & Amšiejus & docentas & pagrindinès & dr. & doc. & Geotechnikos katedra \\
\hline 5 & Daiva & Andriušaitienè & docentas & pagrindinès & dr. & doc. & Socialinės ekonomikos ir vadybos katedra \\
\hline 6 & Aistè & Andriušytė & docentas & pagrindinès & dr. & doc. & Architektūros inžinerijos katedra \\
\hline 7 & Aurimas & Anskaitis & docentas & pagrindinès & dr. & doc. & Telekomunikacijų inžinerijos katedra \\
\hline 8 & Vaida & Asakavičiūtè & docentas & pagrindinès & dr. & & Filosofijos ir politologijos katedra \\
\hline 9 & Arvydas & Astrauskas & docentas & antraeilès & dr. & doc. & Matematinès statistikos katedra \\
\hline 10 & Lina & $\begin{array}{l}\text { Bagdžiūnaitè- } \\
\text { Litvinaitienè }\end{array}$ & docentas & pagrindinès & dr. & doc. & Hidraulikos katedra \\
\hline 11 & Robertas & Balevičius & docentas & pagrindinès & dr. & doc. & $\begin{array}{l}\text { Gelžbetoninių ir mūrinių konstrukciju } \\
\text { katedra }\end{array}$ \\
\hline 12 & Zigmas & Balevičius & docentas & antraeilès & dr. & & Kompiuterių inžinerijos katedra \\
\hline 13 & Nerija & Banaitienè & docentas & pagrindinès & dr. & doc. & $\begin{array}{l}\text { Statybos ekonomikos ir nekilnojamojo turto } \\
\text { vadybos katedra }\end{array}$ \\
\hline 14 & Rimas & Banys & docentas & pagrindinès & dr. & doc. & Matematinès statistikos katedra \\
\hline 15 & Kęstutis & Bartnykas & docentas & pagrindinès & dr. & & Elektroninių sistemų katedra \\
\hline 16 & Vilius & Bartulis & docentas & pagrindinès & dr. & doc. & Transporto technologiniu irenginių katedra \\
\hline 17 & Arūnas & Barvidas & docentas & pagrindinès & dr. & & Statybos technologijos ir vadybos katedra \\
\hline 18 & Oksana & Barvidienè & docentas & pagrindinès & dr. & doc. & Hidraulikos katedra \\
\hline 19 & Vaidotas & Barzdènas & docentas & pagrindinès & dr. & doc. & Kompiuterių inžinerijos katedra \\
\hline 20 & Vaidas & Batkauskas & docentas & antraeilès & dr. & doc. & Telekomunikacijų inžinerijos katedra \\
\hline 21 & Vygintas & Batkauskas & docentas & antraeilès & dr. & & Automatikos katedra \\
\hline 22 & Darius & Bazaras & docentas & pagrindinès & dr. & doc. & Logistikos ir transporto vadybos katedra \\
\hline 23 & Igoris & Belovas & docentas & antraeilès & dr. & doc. & Matematinio modeliavimo katedra \\
\hline 24 & Lina & Bertulienè & docentas & pagrindinès & dr. & & Keliu katedra \\
\hline 25 & Darius & Biekša & docentas & antraeilès & dr. & & Pastatų energetikos katedra \\
\hline 26 & Audrius & Bitinas & docentas & antraeilès & dr. & & Tarptautinès ekonomikos ir vadybos katedra \\
\hline 27 & Gintautas & Blažiūnas & docentas & antraeilès & & doc. & Architektūros katedra \\
\hline 28 & Vytautas & Bleizgys & docentas & antraeilès & dr. & & Kompiuterių inžinerijos katedra \\
\hline 29 & Aleksejus & Bogdanovičius & docentas & pagrindinès & dr. & doc. & Fizikos katedra \\
\hline 30 & Violeta & Bolutienè & docentas & pagrindinès & dr. & & Aplinkos apsaugos katedra \\
\hline 31 & Jolita & Bradulienè & docentas & pagrindinès & dr. & & Aplinkos apsaugos katedra \\
\hline 32 & Nomeda & Bratčikovienè & docentas & pagrindinès & dr. & & Matematinès statistikos katedra \\
\hline 33 & Justas & Bražiūnas & docentas & antraeilès & dr. & & Transporto technologiniu irenginių katedra \\
\hline 34 & Domantas & Bručas & docentas & pagrindinès & dr. & doc. & Aviacinès mechanikos katedra \\
\hline 35 & Šarūnas & Bruzgè & docentas & antraeilès & dr. & & İmonių ekonomikos ir vadybos katedra \\
\hline 36 & Ingrida & Bružaitè & docentas & pagrindinès & dr. & doc. & Chemijos ir bioinžinerijos katedra \\
\hline 37 & Valdas & Bubelevičius & docentas & pagrindinès & & doc. & Dailès katedra \\
\hline 38 & Jonas & Bukevičius & docentas & antraeilès & dr. & doc. & Finansų inžinerijos katedra \\
\hline 39 & Aurelija & Burinskienè & docentas & pagrindinès & dr. & doc. & Verslo technologijų katedra \\
\hline 40 & Daiva & Burkšaitienè & docentas & pagrindinès & dr. & doc. & Finansų inžinerijos katedra \\
\hline 41 & Viktoras & Chadyšas & docentas & pagrindinès & dr. & & Matematinès statistikos katedra \\
\hline 42 & Jevgenij & Charlamov & docentas & antraeilès & dr. & & Kompiuterių inžinerijos katedra \\
\hline 43 & Olegas & Černašèjus & docentas & pagrindinès & dr. & doc. & Medžiagotyros ir suvirinimo katedra \\
\hline 44 & Aurimas & Čerškus & docentas & antraeilès & dr. & & Mechatronikos ir robotikos katedra \\
\hline 45 & Renata & Činčikaitè & docentas & pagrindinès & dr. & & Verslo technologijų katedra \\
\hline 46 & Stasys & Čirba & docentas & pagrindinès & dr. & doc. & Matematinio modeliavimo katedra \\
\hline 47 & Lionginas & Čiupaila & docentas & pagrindinès & dr. & doc. & Inžinerinès grafikos katedra \\
\hline 48 & Regimantas & Čiupaila & docentas & pagrindinès & dr. & doc. & Matematinio modeliavimo katedra \\
\hline
\end{tabular}




\begin{tabular}{|c|c|c|c|c|c|c|c|}
\hline $\begin{array}{l}\text { Eil. } \\
\text { Nr. }\end{array}$ & Vardas & Pavardè & Pareigos & $\begin{array}{l}\text { Pareigu } \\
\text { tipas }\end{array}$ & $\begin{array}{l}\text { Mokslo } \\
\text { laipsnis }\end{array}$ & $\begin{array}{l}\text { Pedagoginis } \\
\text { vardas }\end{array}$ & Padalinys \\
\hline 49 & Kęstutis & Čiuprinskas & docentas & pagrindinès & dr. & doc. & Pastatu energetikos katedra \\
\hline 50 & Kristina & Čižiūnienè & docentas & pagrindinès & dr. & & Logistikos ir transporto vadybos katedra \\
\hline 51 & Marius & Dagys & docentas & antraeilès & dr. & & Chemijos ir bioinžinerijos katedra \\
\hline 52 & Stasys & Dailydka & docentas & antraeilès & dr. & & Geležinkelių transporto katedra \\
\hline 53 & Jovita & Damauskaitè & docentas & pagrindinès & dr. & & Fizikos katedra \\
\hline 54 & Vladislavas & Daškevičius & docentas & antraeilès & dr. & doc. & Kompiuterių inžinerijos katedra \\
\hline 55 & Mykolas & Daugevičius & docentas & pagrindinès & dr. & & $\begin{array}{l}\text { Gelžbetoninių ir mūrinių konstrukciju } \\
\text { katedra }\end{array}$ \\
\hline 56 & Regimantas & Dauknys & docentas & pagrindinès & dr. & doc. & Vandentvarkos katedra \\
\hline 57 & Asta & Daunaravičienè & docentas & pagrindinès & dr. & doc. & Fizikos katedra \\
\hline 58 & Kristina & Daunoravičienè & docentas & pagrindinès & dr. & doc. & Biomechanikos katedra \\
\hline 59 & Titas & Dèjus & docentas & pagrindinès & dr. & doc. & Statybos technologijos ir vadybos katedra \\
\hline 60 & Dovilè & Deltuviené & docentas & pagrindinès & dr. & doc. & Matematinės statistikos katedra \\
\hline 61 & Jelena & Devenson & docentas & antraeilès & dr. & & Grafinių sistemų katedra \\
\hline 62 & Dalia & Dijokienè & docentas & pagrindinès & dr. & doc. & Urbanistikos katedra \\
\hline 63 & Neringa & Dirgèlienè & docentas & pagrindinès & dr. & doc. & Geotechnikos katedra \\
\hline 64 & Rolandas & Drejeris & docentas & pagrindinès & dr. & doc. & Socialinės ekonomikos ir vadybos katedra \\
\hline 65 & Gitana & Dudzevičiūtè & docentas & antraeilès & dr. & doc. & Imoniu ekonomikos ir vadybos katedra \\
\hline 66 & Irena & Dumalakienè & docentas & antraeilès & dr. & & Chemijos ir bioinžinerijos katedra \\
\hline 67 & Ignas & Dzemyda & docentas & pagrindinès & dr. & & Tarptautinès ekonomikos ir vadybos katedra \\
\hline 68 & Audrius & Dzikevičius & docentas & pagrindinès & dr. & doc. & Finansų inžinerijos katedra \\
\hline 69 & Dalia & Eidukienè & docentas & pagrindinès & dr. & doc. & Filosofijos ir politologijos katedra \\
\hline 70 & Arnoldas & Gabrènas & docentas & pagrindinès & dr. & & Architektūros katedra \\
\hline 71 & Sergejus & Gaidučis & docentas & pagrindinès & dr. & & Darbo ir gaisrinės saugos katedra \\
\hline 72 & Inesa & Gailienè & docentas & pagrindinès & dr. & doc. & Keliu katedra \\
\hline 73 & Giedrius & Garbinčius & docentas & pagrindinès & dr. & doc. & Automobiliu transporto katedra \\
\hline 74 & Inga & $\begin{array}{l}\text { Garnytè- } \\
\text { Sapranavičienè }\end{array}$ & docentas & pagrindinès & & & Architektūros inžinerijos katedra \\
\hline 75 & Kristina & $\begin{array}{l}\text { Garškaitè- } \\
\text { Milvydienè }\end{array}$ & docentas & pagrindinès & dr. & & Finansų inžinerijos katedra \\
\hline 76 & Eimantas & Garšva & docentas & antraeilès & dr. & doc. & Kompiuterių inžinerijos katedra \\
\hline 77 & Irmantas & Gedzevičius & docentas & pagrindinès & dr. & doc. & Medžiagotyros ir suvirinimo katedra \\
\hline 78 & Andrejus & Geižutis & docentas & antraeilès & dr. & doc. & Elektroniniu sistemu katedra \\
\hline 79 & Virginijus & Gerdvilis & docentas & pagrindinès & dr. & doc. & Architektūros katedra \\
\hline 80 & Vladimir & Gičan & docentas & pagrindinès & dr. & doc. & Poligrafinių mašinų katedra \\
\hline 81 & Raselè & Girgždienè & docentas & antraeilès & dr. & doc. & Fizikos katedra \\
\hline 82 & Valmantas & Girnius & docentas & pagrindinès & dr. & doc. & Darbo ir gaisrinès saugos katedra \\
\hline 83 & Nikolaj & Goranin & docentas & pagrindinès & dr. & doc. & Informaciniu sistemu katedra \\
\hline 84 & Audrius & Grainys & docentas & pagrindinès & dr. & & Elektrotechnikos katedra \\
\hline 85 & Gediminas & Gražulevičius & docentas & pagrindinès & dr. & doc. & Kompiuterių inžinerijos katedra \\
\hline 86 & Viktor & Gribniak & docentas & pagrindinès & dr. & & Tiltu ir specialiujų statiniu katedra \\
\hline 87 & Gražina & $\begin{array}{l}\text { Grigaliūnaitè- } \\
\text { Vonsevičienè }\end{array}$ & docentas & pagrindinès & dr. & doc. & Fizikos katedra \\
\hline 88 & Vytautas & Grigonis & docentas & pagrindinès & dr. & doc. & Miestu statybos katedra \\
\hline 89 & Tatjana & Grigorjeva & docentas & pagrindinès & dr. & doc. & Architektūros inžinerijos katedra \\
\hline 90 & Daiva & Griškevičienè & docentas & pagrindinès & dr. & doc. & Logistikos ir transporto vadybos katedra \\
\hline 91 & Mečislavas & Griškevičius & docentas & antraeilès & dr. & & Darbo ir gaisrinès saugos katedra \\
\hline 92 & Julius & Griškevičius & docentas & pagrindinès & dr. & doc. & Biomechanikos katedra \\
\hline 93 & Raimondas & Grubliauskas & docentas & pagrindinès & dr. & & Aplinkos apsaugos katedra \\
\hline 94 & Tomas & Grunskis & docentas & pagrindinès & dr. & doc. & Architektūros pagrindų ir teorijos katedra \\
\hline 95 & Kęstutis & Gurkšnys & docentas & pagrindinès & dr. & doc. & Metalinių ir medinių konstrukcijų katedra \\
\hline 96 & Antanas & Gurskas & docentas & antraeilès & dr. & doc. & Elektroninių sistemų katedra \\
\hline 97 & Darius & Guršnys & docentas & pagrindinès & dr. & doc. & Telekomunikaciju inžinerijos katedra \\
\hline 98 & Natalija & Guseva & docentas & antraeilès & dr. & & Verslo technologijų katedra \\
\hline
\end{tabular}




\begin{tabular}{|c|c|c|c|c|c|c|c|}
\hline $\begin{array}{l}\text { Eil. } \\
\text { Nr. }\end{array}$ & Vardas & Pavardè & Pareigos & $\begin{array}{l}\text { Pareigų } \\
\text { tipas }\end{array}$ & $\begin{array}{l}\text { Mokslo } \\
\text { laipsnis }\end{array}$ & $\begin{array}{l}\text { Pedagoginis } \\
\text { vardas }\end{array}$ & Padalinys \\
\hline 99 & Igor & Iljin & docentas & pagrindinès & dr. & doc. & Poligrafinių mašinų katedra \\
\hline 100 & Rūta & Ivanec-Goranina & docentas & pagrindinès & dr. & & Chemijos ir bioinžinerijos katedra \\
\hline 101 & Sergèjus & Ivanikovas & docentas & pagrindinès & dr. & & Informacinių technologijų katedra \\
\hline 102 & Aleksandras & Jagniatinskis & docentas & pagrindinès & dr. & & Pastatų konstrukcijų katedra \\
\hline 103 & Jonas & Jakaitis & docentas & pagrindinès & dr. & doc. & Dizaino katedra \\
\hline 104 & Marius & Jakimavičius & docentas & antraeilès & $\mathrm{dr}$. & doc. & Miestų statybos katedra \\
\hline 105 & Dalia & Janeliauskienè & docentas & antraeilès & dr. & & Vandentvarkos katedra \\
\hline 106 & Robertas & Janickas & docentas & antraeilès & dr. & & Automatikos katedra \\
\hline 107 & Gerda & Jankevičiūtè & docentas & pagrindinès & $\mathrm{dr}$. & & Matematinio modeliavimo katedra \\
\hline 108 & Andrius & Jaržemskis & docentas & pagrindinès & dr. & doc. & Logistikos ir transporto vadybos katedra \\
\hline 109 & Vytautas & Jaržemskis & docentas & pagrindinès & dr. & doc. & Logistikos ir transporto vadybos katedra \\
\hline 110 & Dainius & Jasaitis & docentas & pagrindinès & $\mathrm{dr}$ & doc. & Fizikos katedra \\
\hline 111 & Vilma & Jasiūnienè & docentas & pagrindinès & $\mathrm{dr}$ & & Kelių katedra \\
\hline 112 & Eglè & Jaškūnienè & docentas & pagrindinès & dr. & & Kūrybos verslo ir komunikacijos katedra \\
\hline 113 & Donatas & Jatulis & docentas & pagrindinès & $\mathrm{dr}$. & & Tiltų ir specialiujų statinių katedra \\
\hline 114 & Izolda & Jokšienè & docentas & pagrindinès & $\mathrm{dr}$ & & İmonių ekonomikos ir vadybos katedra \\
\hline 115 & Vaclovas & Jonevičius & docentas & antraeilès & dr. & & Transporto technologinių irenginių katedra \\
\hline 116 & Linas & Juknevičius & docentas & pagrindinès & dr. & doc. & $\begin{array}{l}\text { Gelžbetoninių ir mūrinių konstrukciju } \\
\text { katedra }\end{array}$ \\
\hline 117 & Lina & $\begin{array}{l}\text { Juknevičiūtè- } \\
\text { Žilinskiené }\end{array}$ & docentas & pagrindinès & $\mathrm{dr}$ & & Kelių katedra \\
\hline 118 & Raimundas & Junevičius & docentas & pagrindinès & dr. & & Transporto technologinių irenginių katedra \\
\hline 119 & Sigitas & Juraitis & docentas & antraeilès & dr. & & Automatikos katedra \\
\hline 120 & Eugenijus & Jurkonis & docentas & pagrindinès & $\mathrm{dr}$ & doc. & Poligrafinių mašinų katedra \\
\hline 121 & Agnieška & Juzefovič & docentas & pagrindinès & dr. & doc. & Filosofijos ir politologijos katedra \\
\hline 122 & Darius & Kalibatas & docentas & pagrindinès & dr. & doc. & Statybos technologijos ir vadybos katedra \\
\hline 123 & Diana & Kalibatienè & docentas & pagrindinès & $\mathrm{dr}$ & doc. & Informacinių sistemų katedra \\
\hline 124 & Juozas & Kamarauskas & docentas & antraeilès & $\mathrm{dr}$. & & Grafinių sistemų katedra \\
\hline 125 & Loreta & Kanapeckienè & docentas & pagrindinès & dr. & doc. & $\begin{array}{l}\text { Statybos ekonomikos ir nekilnojamojo turto } \\
\text { vadybos katedra }\end{array}$ \\
\hline 126 & Bronius & Karaliūnas & docentas & pagrindinès & $\mathrm{dr}$ & doc. & Automatikos katedra \\
\hline 127 & Aurelija & Kasparavičiūtè & docentas & pagrindinès & dr. & & Matematinės statistikos katedra \\
\hline 128 & Andrius & Katkevičius & docentas & pagrindinès & $\mathrm{dr}$ & & Elektroninių sistemų katedra \\
\hline 129 & Angelè & Kaulakienè & docentas & pagrindinès & dr. & doc. & Lietuvių kalbos katedra \\
\hline 130 & Saulius & Kavaliauskas & docentas & pagrindinès & dr. & & Metalinių ir medinių konstrukcijų katedra \\
\hline 131 & Girūta & $\begin{array}{l}\text { Kazakevičiūtè- } \\
\text { Januškevičienè }\end{array}$ & docentas & pagrindinès & dr. & doc. & Grafinių sistemų katedra \\
\hline 132 & Agnè & Kazlauskienè & docentas & pagrindinès & dr. & & Aplinkos apsaugos katedra \\
\hline 133 & Violeta & Keršulienè & docentas & pagrindinès & $\mathrm{dr}$ & doc. & Teisės katedra \\
\hline 134 & Asta & Kičaitè & docentas & pagrindinès & dr. & doc. & Statybinių medžiagų katedra \\
\hline 135 & Artūras & Kilikevičius & docentas & pagrindinès & $\mathrm{dr}$ & doc. & Mechanikos inžinerijos katedra \\
\hline 136 & Jevgenijus & Kirjackis & docentas & pagrindinès & $\mathrm{dr}$. & doc. & Matematinio modeliavimo katedra \\
\hline 137 & Arūnas & Komka & docentas & pagrindinès & dr. & doc. & Metalinių ir medinių konstrukcijų katedra \\
\hline 138 & Renata & Korsakienè & docentas & pagrindinès & $\mathrm{dr}$ & doc. & İmoniu ekonomikos ir vadybos katedra \\
\hline 139 & Natalja & Kosareva & docentas & pagrindinès & dr. & doc. & Matematinio modeliavimo katedra \\
\hline 140 & Jonas & Kriaučiūnas & docentas & pagrindinès & $\mathrm{dr}$ & & Automatikos katedra \\
\hline 141 & Boleslovas & Krikštaponis & docentas & pagrindinès & dr. & doc. & Geodezijos ir kadastro katedra \\
\hline 142 & Algirdas & Krivka & docentas & antraeilès & $\mathrm{dr}$. & & İmoniu ekonomikos ir vadybos katedra \\
\hline 143 & Birutè Aldona & Kryžienė & docentas & pagrindinès & $\mathrm{dr}$. & doc. & Matematinės statistikos katedra \\
\hline 144 & Linas & Krūgelis & docentas & pagrindinès & dr. & & Dizaino katedra \\
\hline 145 & Audrius & Krukonis & docentas & pagrindinès & $\mathrm{dr}$. & & Elektroninių sistemų katedra \\
\hline 146 & Algirdas & Krupovnickas & docentas & antraeilès & $\mathrm{dr}$. & & Informacinių technologijų katedra \\
\hline 147 & Aušra & Kumetaitienè & docentas & antraeilès & dr. & doc. & Geodezijos ir kadastro katedra \\
\hline 148 & Sigitas & Kuncevičius & docentas & pagrindinès & & doc. & Architektūros katedra \\
\hline
\end{tabular}




\begin{tabular}{|c|c|c|c|c|c|c|c|}
\hline $\begin{array}{l}\text { Eil. } \\
\text { Nr. }\end{array}$ & Vardas & Pavardè & Pareigos & $\begin{array}{l}\text { Pareigu } \\
\text { tipas }\end{array}$ & $\begin{array}{l}\text { Mokslo } \\
\text { laipsnis }\end{array}$ & $\begin{array}{l}\text { Pedagoginis } \\
\text { vardas }\end{array}$ & Padalinys \\
\hline 149 & Jevgenij & Kurilov & docentas & antraeilès & dr. & doc. & Informaciniu technologiju katedra \\
\hline 150 & Remigijus & Kutas & docentas & pagrindinès & dr. & doc. & Informacinių sistemų katedra \\
\hline 151 & Vladislavas & Kutut & docentas & antraeilès & dr. & doc. & Statybos technologijos ir vadybos katedra \\
\hline 152 & Rokas & Kvedaras & docentas & antraeilès & dr. & doc. & Elektroniniu sistemų katedra \\
\hline 153 & Indrè & Lapinskaitè & docentas & pagrindinès & dr. & & Finansų inžinerijos katedra \\
\hline 154 & Raimond & Laptik & docentas & pagrindinès & dr. & & Elektroniniu sistemų katedra \\
\hline 155 & Eduardas & Lasauskas & docentas & pagrindinès & dr. & doc. & Aviacinės mechanikos katedra \\
\hline 156 & Juozas & Laučius & docentas & pagrindinès & dr. & doc. & Informacinių sistemų katedra \\
\hline 157 & Algirdas & Laukaitis & docentas & pagrindinès & dr. & & Informacinių sistemų katedra \\
\hline 158 & Simonas & Laurinavičius & docentas & antraeilès & dr. & & Chemijos ir bioinžinerijos katedra \\
\hline 159 & Jekaterina & Lavrinec & docentas & pagrindinès & dr. & & Filosofijos ir politologijos katedra \\
\hline 160 & Jonas & Lazauskas & docentas & pagrindinès & dr. & doc. & Logistikos ir transporto vadybos katedra \\
\hline 161 & Teresè & Leonavičienè & docentas & pagrindinès & dr. & doc. & Matematinio modeliavimo katedra \\
\hline 162 & Natalija & Lepkova & docentas & pagrindinès & dr. & doc. & $\begin{array}{l}\text { Statybos ekonomikos ir nekilnojamojo turto } \\
\text { vadybos katedra }\end{array}$ \\
\hline 163 & Valentina & Liakina & docentas & antraeilès & dr. & & Biomechanikos katedra \\
\hline 164 & Darius & Linartas & docentas & pagrindinès & dr. & & Architektūros katedra \\
\hline 165 & Saulius & Lisauskas & docentas & pagrindinès & dr. & doc. & Automatikos katedra \\
\hline 166 & Andrius & Litvinaitis & docentas & pagrindinès & dr. & & Hidraulikos katedra \\
\hline 167 & Aušra & Liučvaitienè & docentas & pagrindinès & dr. & doc. & İmonių ekonomikos ir vadybos katedra \\
\hline 168 & Lionginas & Liudvinavičius & docentas & pagrindinès & dr. & & Geležinkelių transporto katedra \\
\hline 169 & Evaldas & Liutkevičius & docentas & pagrindinès & dr. & & Chemijos ir bioinžinerijos katedra \\
\hline 170 & Tomas & Luneckas & docentas & pagrindinès & dr. & & Automatikos katedra \\
\hline 171 & Augustinas & Maceika & docentas & pagrindinès & dr. & doc. & Mechanikos inžinerijos katedra \\
\hline 172 & Rimantas & Mackevičius & docentas & pagrindinès & dr. & doc. & Geotechnikos katedra \\
\hline 173 & Darius & Mačiūnas & docentas & pagrindinès & dr. & & $\begin{array}{l}\text { Medžiagu atsparumo ir teorinès } \\
\text { mechanikos katedra }\end{array}$ \\
\hline 174 & Algirdas & Maknickas & docentas & pagrindinès & dr. & & Informaciniu technologiju katedra \\
\hline 175 & Daiva & Makutènienè & docentas & pagrindinès & dr. & doc. & Inžinerinès grafikos katedra \\
\hline 176 & Jelena & Mamčenko & docentas & pagrindinès & dr. & doc. & Informaciniu technologiju katedra \\
\hline 177 & Eglè & Marčiulaitienè & docentas & pagrindinès & dr. & & Aplinkos apsaugos katedra \\
\hline 178 & Darius & Markauskas & docentas & pagrindinès & dr. & & $\begin{array}{l}\text { Medžiagu atsparumo ir teorinès } \\
\text { mechanikos katedra }\end{array}$ \\
\hline 179 & Lada & Markejevaitè & docentas & pagrindinès & dr. & doc. & Architektūros katedra \\
\hline 180 & Raimonda & $\begin{array}{l}\text { Martinkutè- } \\
\text { Kaulienè }\end{array}$ & docentas & pagrindinès & dr. & doc. & Finansų inžinerijos katedra \\
\hline 181 & Giedrius & Masalskis & docentas & antraeilès & dr. & & Kompiuterių inžinerijos katedra \\
\hline 182 & Ričardas & Masiulionis & docentas & pagrindinès & dr. & & Elektrotechnikos katedra \\
\hline 183 & Darius & Mateika & docentas & antraeilès & dr. & & Elektroninių sistemų katedra \\
\hline 184 & Jonas & Matijošius & docentas & pagrindinès & dr. & doc. & Automobilių transporto katedra \\
\hline 185 & Edvardas & Matkevičius & docentas & pagrindinès & dr. & doc. & Automatikos katedra \\
\hline 186 & Jurgita & Matulienè & docentas & antraeilès & dr. & & Chemijos ir bioinžinerijos katedra \\
\hline 187 & Dalius & Matuzevičius & docentas & pagrindinès & dr. & & Elektroniniu sistemu katedra \\
\hline 188 & Aušra & Mažeikienè & docentas & pagrindinès & dr. & doc. & Vandentvarkos katedra \\
\hline 189 & Jurgis & Medzvieckas & docentas & pagrindinès & dr. & doc. & Geotechnikos katedra \\
\hline 190 & leva & $\begin{array}{l}\text { Meidutè- } \\
\text { Kavaliauskienè }\end{array}$ & docentas & pagrindinès & dr. & doc. & Verslo technologijų katedra \\
\hline 191 & Mečislavas & Meilūnas & docentas & pagrindinès & dr. & doc. & Matematinio modeliavimo katedra \\
\hline 192 & Dmitrij & Melichov & docentas & pagrindinès & dr. & & Matematinės statistikos katedra \\
\hline 193 & Juozas & Merkevičius & docentas & pagrindinès & dr. & doc. & Verslo technologijų katedra \\
\hline 194 & Dovilè & Merkevičiūtè & docentas & pagrindinès & dr. & 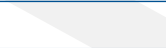 & Statybinès mechanikos katedra \\
\hline 195 & Edvardas & Metlevskis & docentas & pagrindinès & dr. & & Elektroninių sistemų katedra \\
\hline 196 & Edvard & Michnevič & docentas & pagrindinès & dr. & doc. & $\begin{array}{l}\text { Medžiagu atsparumo ir teorinès } \\
\text { mechanikos katedra }\end{array}$ \\
\hline 197 & Marius & Mickaitis & docentas & pagrindinès & dr. & doc. & Pastatų konstrukcijų katedra \\
\hline
\end{tabular}




\begin{tabular}{|c|c|c|c|c|c|c|c|}
\hline $\begin{array}{l}\text { Eil. } \\
\text { Nr. }\end{array}$ & Vardas & Pavardè & Pareigos & $\begin{array}{l}\text { Pareigu } \\
\text { tipas }\end{array}$ & $\begin{array}{l}\text { Mokslo } \\
\text { laipsnis }\end{array}$ & $\begin{array}{l}\text { Pedagoginis } \\
\text { vardas }\end{array}$ & Padalinys \\
\hline 198 & Arūnas & Mickevičius & docentas & antraeilès & dr. & doc. & Kūrybos verslo ir komunikacijos katedra \\
\hline 199 & Algita & Miečinskienè & docentas & pagrindinès & dr. & doc. & Finansų inžinerijos katedra \\
\hline 200 & Darius & Migilinskas & docentas & antraeilès & dr. & & Statybos technologijos ir vadybos katedra \\
\hline 201 & Audronè & Mikalajūnè & docentas & pagrindinès & $\mathrm{dr}$. & & Aplinkos apsaugos katedra \\
\hline 202 & Šarūnas & Mikaliūnas & docentas & pagrindinès & dr. & doc. & Geležinkelių transporto katedra \\
\hline 203 & Gytis & Mykolaitis & docentas & pagrindinès & $\mathrm{dr}$. & doc. & Fizikos katedra \\
\hline 204 & Saulius & Mikštas & docentas & antraeilès & & doc. & Architektūros katedra \\
\hline 205 & Darius & Miniotas & docentas & pagrindinès & dr. & doc. & Aviacijos prietaisu katedra \\
\hline 206 & Violeta & Misevičiūtè & docentas & pagrindinès & $\mathrm{dr}$. & & Pastatų energetikos katedra \\
\hline 207 & leva & Misiūnaitè & docentas & pagrindinès & dr. & & Tiltų ir specialiuju statinių katedra \\
\hline 208 & Dainius & Miškinis & docentas & antraeilès & dr. & doc. & Kelių katedra \\
\hline 209 & Anastasija & Moisejenkova & docentas & pagrindinès & dr. & & Fizikos katedra \\
\hline 210 & Vadim & Mokšin & docentas & pagrindinès & dr. & doc. & Mechanikos inžinerijos katedra \\
\hline 211 & Laimutè & Monginaitè & docentas & pagrindinès & dr. & & Filosofijos ir politologijos katedra \\
\hline 212 & Saulius & Motieka & docentas & antraeilès & & doc. & Urbanistikos katedra \\
\hline 213 & Violeta & Motuzienè & docentas & pagrindinès & dr. & doc. & Pastatu energetikos katedra \\
\hline 214 & Skirmantė & Mozūriūnaitè & docentas & pagrindinès & dr. & & Urbanistikos katedra \\
\hline 215 & Džigita & Nagrockienè & docentas & pagrindinès & dr. & doc. & Statybinių medžiagų katedra \\
\hline 216 & Saulius & Nagurnas & docentas & pagrindinès & dr. & doc. & Automobilių transporto katedra \\
\hline 217 & Jurga & Naimavičienè & docentas & pagrindinès & dr. & doc. & $\begin{array}{l}\text { Statybos ekonomikos ir nekilnojamojo turto } \\
\text { vadybos katedra }\end{array}$ \\
\hline 218 & Linas & Naujokaitis & docentas & antraeilès & & doc. & Architektūros katedra \\
\hline 219 & Eglè & Navickienè & docentas & pagrindinès & dr. & doc. & Architektūros katedra \\
\hline 220 & Vilma & Nekrašaitè-Liegè & docentas & pagrindinès & dr. & & Matematinès statistikos katedra \\
\hline 221 & Liutauras & Nekrošius & docentas & pagrindinès & dr. & & Architektūros pagrindu ir teorijos katedra \\
\hline 222 & Edgaras & Neniškis & docentas & pagrindinès & dr. & doc. & Urbanistikos katedra \\
\hline 223 & Meda & Norbutaitè & docentas & pagrindinès & & & Grafinių sistemų katedra \\
\hline 224 & Jolita & Norkūnienè & docentas & pagrindinès & dr. & doc. & Matematinès statistikos katedra \\
\hline 225 & Audrius & Novickas & docentas & pagrindinès & dr. & doc. & Dailès katedra \\
\hline 226 & Romuald & Obuchovski & docentas & pagrindinès & dr. & doc. & Geodezijos ir kadastro katedra \\
\hline 227 & Rolandas & Oginskas & docentas & pagrindinès & $\mathrm{dr}$. & doc. & Kelių katedra \\
\hline 228 & Laima & $\begin{array}{l}\text { Okunevičiūtè } \\
\text { Neverauskienè }\end{array}$ & docentas & pagrindinès & dr. & doc. & Socialinès ekonomikos ir vadybos katedra \\
\hline 229 & Egidijus & Ostašius & docentas & pagrindinès & dr. & & Informacinių technologijų katedra \\
\hline 230 & Arnoldina Ona & Pabedinskaitè & docentas & pagrindinès & dr. & doc. & Verslo technologiju katedra \\
\hline 231 & Kazimieras & Padvelskis & docentas & pagrindinès & dr. & doc. & Matematinès statistikos katedra \\
\hline 232 & Mindaugas & Pakalnis & docentas & antraeilès & & & Urbanistikos katedra \\
\hline 233 & $\begin{array}{l}\text { Gražvydas } \\
\text { Mykolas }\end{array}$ & Paliulis & docentas & pagrindinès & dr. & doc. & Miestų statybos katedra \\
\hline 234 & Dainius & Paliulis & docentas & pagrindinès & dr. & doc. & Aplinkos apsaugos katedra \\
\hline 235 & Saulius & Pamerneckis & docentas & pagrindinès & & & Architektūros katedra \\
\hline 236 & Vytautas & Papinigis & docentas & antraeilès & dr. & doc. & $\begin{array}{l}\text { Gelžbetoninių ir mūrinių konstrukciju } \\
\text { katedra }\end{array}$ \\
\hline 237 & $\begin{array}{l}\text { Marija Jūratè } \\
\text { Laimutè }\end{array}$ & Patašiūtè & docentas & pagrindinès & dr. & & Aviacijos technologiju katedra \\
\hline 238 & Sabina & Paulauskaitè & docentas & pagrindinès & dr. & doc. & Pastatu energetikos katedra \\
\hline 239 & Nerijus & Paulauskas & docentas & pagrindinès & dr. & doc. & Kompiuterių inžinerijos katedra \\
\hline 240 & Lukas & Pavilanskas & docentas & antraeilès & dr. & doc. & Telekomunikacijų inžinerijos katedra \\
\hline 241 & Robertas & Pečeliūnas & docentas & pagrindinès & dr. & doc. & Automobilių transporto katedra \\
\hline 242 & Milda & Pečiulienè & docentas & pagrindinès & dr. & doc. & Fizikos katedra \\
\hline 243 & Valentina & Peleckienè & docentas & pagrindinès & dr. & doc. & Socialinès ekonomikos ir vadybos katedra \\
\hline 244 & Gediminas & Petraitis & docentas & pagrindinès & dr. & doc. & $\begin{array}{l}\text { Medžiagu atsparumo ir teorinès } \\
\text { mechanikos katedra }\end{array}$ \\
\hline 245 & Artūras & Petraška & docentas & antraeilès & dr. & & Logistikos ir transporto vadybos katedra \\
\hline 246 & Vladislavas & Petraškevičius & docentas & antraeilès & dr. & doc. & Socialinès ekonomikos ir vadybos katedra \\
\hline
\end{tabular}




\begin{tabular}{|c|c|c|c|c|c|c|c|}
\hline $\begin{array}{l}\text { Eil. } \\
\text { Nr. }\end{array}$ & Vardas & Pavardè & Pareigos & $\begin{array}{l}\text { Pareigu } \\
\text { tipas }\end{array}$ & $\begin{array}{l}\text { Mokslo } \\
\text { laipsnis }\end{array}$ & $\begin{array}{l}\text { Pedagoginis } \\
\text { vardas }\end{array}$ & Padalinys \\
\hline 247 & Andrius & Petrovas & docentas & pagrindinès & dr. & doc. & Automatikos katedra \\
\hline 248 & Vytautas & Petrušonis & docentas & pagrindinès & dr. & doc. & Architektūros pagrindų ir teorijos katedra \\
\hline 249 & Augustas & Pivoriūnas & docentas & antraeilès & dr. & & Chemijos ir bioinžinerijos katedra \\
\hline 250 & Andrius & Platakis & docentas & antraeilès & dr. & & Kompiuterių inžinerijos katedra \\
\hline 251 & Birutè & Pliuskuvienè & docentas & pagrindinès & dr. & & Informacinių sistemu katedra \\
\hline 252 & Darius & Plonis & docentas & pagrindinès & dr. & & Elektroninių sistemų katedra \\
\hline 253 & $\begin{array}{l}\text { Ričardas } \\
\text { Visvaldas }\end{array}$ & Pocius & docentas & pagrindinès & dr. & doc. & Telekomunikacijų inžinerijos katedra \\
\hline 254 & Igoris & Podagèlis & docentas & pagrindinès & dr. & doc. & Keliu katedra \\
\hline 255 & Raimondas & Pomarnacki & docentas & pagrindinès & dr. & & Elektroninių sistemų katedra \\
\hline 256 & Vladimir & Popov & docentas & pagrindinès & dr. & doc. & $\begin{array}{l}\text { Gelžbetoninių ir mūrinių konstrukciju } \\
\text { katedra }\end{array}$ \\
\hline 257 & Michail & Popov & docentas & pagrindinès & dr. & & Statybinès mechanikos katedra \\
\hline 258 & Darius & Popovas & docentas & pagrindinès & dr. & & Geodezijos ir kadastro katedra \\
\hline 259 & Darius & Poviliauskas & docentas & antraeilès & dr. & doc. & Kompiuterių inžinerijos katedra \\
\hline 260 & Lilija & Puipienè & docentas & pagrindinès & & & Dailès katedra \\
\hline 261 & Virgaudas & Puodžiukas & docentas & pagrindinès & dr. & doc. & Keliu katedra \\
\hline 262 & Lina & Pupeikienè & docentas & pagrindinès & dr. & doc. & Informacinių technologijų katedra \\
\hline 263 & Rimantas & Pupeikis & docentas & antraeilès & dr. & doc. & Elektroninių sistemu katedra \\
\hline 264 & Raimundas & Putrimas & docentas & pagrindinès & dr. & doc. & Geodezijos ir kadastro katedra \\
\hline 265 & Rūta & Puzienè & docentas & pagrindinès & dr. & & Geodezijos ir kadastro katedra \\
\hline 266 & Jolita & Radušienè & docentas & antraeilès & dr. & doc. & Chemijos ir bioinžinerijos katedra \\
\hline 267 & Asta & Radzevičienè & docentas & pagrindinès & dr. & doc. & Tarptautinès ekonomikos ir vadybos katedra \\
\hline 268 & Egidijus & Radzevičius & docentas & antraeilès & dr. & & Teisès katedra \\
\hline 269 & Simona & Ramanauskaitè & docentas & pagrindinès & dr. & & Informacinių technologijų katedra \\
\hline 270 & Konstantin & Rasiulis & docentas & pagrindinès & dr. & & Metalinių ir mediniu konstrukciju katedra \\
\hline 271 & Kornelija & Ratkevičiūtè & docentas & pagrindinès & dr. & & Keliu katedra \\
\hline 272 & Jurgita & Raudeliūnienè & docentas & pagrindinès & dr. & doc. & Verslo technologijų katedra \\
\hline 273 & Tomas & Rekašius & docentas & pagrindinès & dr. & & Matematinès statistikos katedra \\
\hline 274 & Edita & Riaubienè & docentas & pagrindinès & dr. & doc. & Architektūros pagrindų ir teorijos katedra \\
\hline 275 & Mindaugas & Rybokas & docentas & pagrindinès & dr. & doc. & Informacinių technologijų katedra \\
\hline 276 & Mindaugas & Rimeika & docentas & pagrindinès & dr. & doc. & Vandentvarkos katedra \\
\hline 277 & Liudvikas & Rimkus & docentas & pagrindinès & dr. & doc. & Statybinès mechanikos katedra \\
\hline 278 & Alfredas & Rimkus & docentas & antraeilès & dr. & & Automobiliu transporto katedra \\
\hline 279 & Vytautas & Rimša & docentas & pagrindinès & dr. & & Aviacijos technologiju katedra \\
\hline 280 & Artur & Rogoža & docentas & pagrindinès & dr. & doc. & Pastatu energetikos katedra \\
\hline 281 & Darius & Rudinskas & docentas & pagrindinès & dr. & & Aviacijos prietaisu katedra \\
\hline 282 & Vitalijus & Rudzinskas & docentas & pagrindinès & dr. & doc. & Medžiagotyros ir suvirinimo katedra \\
\hline 283 & Indrè & Ruseckaitè & docentas & antraeilès & dr. & & Architektūros pagrindụ ir teorijos katedra \\
\hline 284 & Tatjana & Rusko & docentas & pagrindinès & dr. & doc. & Užsienio kalbų katedra \\
\hline 285 & Birutè & Ruzgienè & docentas & pagrindinès & dr. & doc. & Geodezijos ir kadastro katedra \\
\hline 286 & Jolanta & Saldukaitytè & docentas & pagrindinès & & & Filosofijos ir politologijos katedra \\
\hline 287 & Michail & Samofalov & docentas & pagrindinès & dr. & doc. & $\begin{array}{l}\text { Medžiagu atsparumo ir teorinès mechani- } \\
\text { kos katedra }\end{array}$ \\
\hline 288 & Zita & Savickienè & docentas & pagrindinès & dr. & doc. & Automatikos katedra \\
\hline 289 & Živilè & $\begin{array}{l}\text { Sederevičiūtè- } \\
\text { Pačiauskienè }\end{array}$ & docentas & pagrindinès & dr. & doc. & Kūrybos verslo ir komunikacijos katedra \\
\hline 290 & Dalius & Seliuta & docentas & antraeilès & dr. & doc. & Elektroninių sistemų katedra \\
\hline 291 & Jelena & Selivonec & docentas & pagrindinès & dr. & doc. & $\begin{array}{l}\text { Medžiagu atsparumo ir teorinès mechani- } \\
\text { kos katedra }\end{array}$ \\
\hline 292 & Saulius & Serva & docentas & antraeilès & dr. & 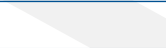 & Chemijos ir bioinžinerijos katedra \\
\hline 293 & Rūta & Simanavičienè & docentas & pagrindinès & dr. & & Matematinès statistikos katedra \\
\hline 294 & Ilona & Skačkauskienė & docentas & pagrindinès & dr. & doc. & Socialinès ekonomikos ir vadybos katedra \\
\hline 295 & Kęstutis & Skerys & docentas & antraeilès & dr. & doc. & Kelių katedra \\
\hline
\end{tabular}




\begin{tabular}{|c|c|c|c|c|c|c|c|}
\hline $\begin{array}{l}\text { Eil. } \\
\text { Nr. }\end{array}$ & Vardas & Pavardè & Pareigos & $\begin{array}{l}\text { Pareigu } \\
\text { tipas }\end{array}$ & $\begin{array}{l}\text { Mokslo } \\
\text { laipsnis }\end{array}$ & $\begin{array}{l}\text { Pedagoginis } \\
\text { vardas }\end{array}$ & Padalinys \\
\hline 296 & Tomas & Skuturna & docentas & pagrindinès & dr. & & $\begin{array}{l}\text { Gelžbetoninių ir mūrinių konstrukciju } \\
\text { katedra }\end{array}$ \\
\hline 297 & Danutè & Sližytè & docentas & pagrindinès & dr. & doc. & Geotechnikos katedra \\
\hline 298 & Algirdas & Sokas & docentas & pagrindinès & dr. & doc. & Inžinerinès grafikos katedra \\
\hline 299 & Jolanta & Solnyškinienè & docentas & pagrindinès & dr. & doc. & Tarptautinès ekonomikos ir vadybos katedra \\
\hline 300 & Arminas & Stanionis & docentas & pagrindinès & dr. & doc. & Geodezijos ir kadastro katedra \\
\hline 301 & Mindaugas & Staniūnas & docentas & pagrindinès & dr. & & Miestų statybos katedra \\
\hline 302 & Asta & Stankevičienè & docentas & antraeilès & dr. & doc. & Imonių ekonomikos ir vadybos katedra \\
\hline 303 & Rasa & Stankevičienè & docentas & pagrindinès & dr. & & Hidraulikos katedra \\
\hline 304 & Aušra & Stankiuvienè & docentas & pagrindinès & dr. & & Darbo ir gaisrinės saugos katedra \\
\hline 305 & Vadimas & Starikovičius & docentas & pagrindinès & dr. & doc. & Matematinio modeliavimo katedra \\
\hline 306 & Viktorija & Stasytytė & docentas & pagrindinès & dr. & & Finansų inžinerijos katedra \\
\hline 307 & Rimantas & Stonkus & docentas & pagrindinès & dr. & & Poligrafinių mašinų katedra \\
\hline 308 & Eglè & Strainienè & docentas & antraeilès & dr. & & Chemijos ir bioinžinerijos katedra \\
\hline 309 & Giedrè & Streckienè & docentas & pagrindinès & dr. & & Pastatu energetikos katedra \\
\hline 310 & Vytautas & Striška & docentas & pagrindinès & dr. & doc. & Mechanikos inžinerijos katedra \\
\hline 311 & Stanislav & Stupak & docentas & pagrindinès & dr. & doc. & $\begin{array}{l}\text { Medžiagų atsparumo ir teorinės } \\
\text { mechanikos katedra }\end{array}$ \\
\hline 312 & Raimund & Stupak & docentas & pagrindinès & & & Urbanistikos katedra \\
\hline 313 & Eugeniuš & Stupak & docentas & pagrindinès & dr. & doc. & $\begin{array}{l}\text { Medžiagu atsparumo ir teorinès } \\
\text { mechanikos katedra }\end{array}$ \\
\hline 314 & Jolanta & Stupakova & docentas & pagrindinès & dr. & doc. & Fizikos katedra \\
\hline 315 & Rimantas & Subačius & docentas & pagrindinès & dr. & doc. & Geležinkelių transporto katedra \\
\hline 316 & Olga & Suboč & docentas & pagrindinès & dr. & doc. & Matematinio modeliavimo katedra \\
\hline 317 & Vladimiras & Suslavičius & docentas & antraeilès & dr. & & Transporto technologiniu irenginių katedra \\
\hline 318 & Jūratè & $\begin{array}{l}\text { Sužiedelytè- } \\
\text { Visockiené }\end{array}$ & docentas & pagrindinès & dr. & doc. & Geodezijos ir kadastro katedra \\
\hline 319 & Jurgita & Šakènaitè & docentas & pagrindinès & dr. & & Darbo ir gaisrinės saugos katedra \\
\hline 320 & Remigijus & Šalna & docentas & pagrindinès & dr. & doc. & $\begin{array}{l}\text { Gelžbetoninių ir mūrinių konstrukcijų } \\
\text { katedra }\end{array}$ \\
\hline 321 & Arūnas & Šaltis & docentas & pagrindinès & dr. & doc. & Telekomunikacijų inžinerijos katedra \\
\hline 322 & Vaidotas & Šapalas & docentas & pagrindinès & dr. & doc. & Metalinių ir medinių konstrukcijų katedra \\
\hline 323 & Jonas & Šaparauskas & docentas & pagrindinès & dr. & doc. & Statybos technologijos ir vadybos katedra \\
\hline 324 & Edita & Šarkienè & docentas & pagrindinès & dr. & & Miestų statybos katedra \\
\hline 325 & Gintas & Šaučiuvėnas & docentas & pagrindinès & dr. & doc. & Metalinių ir medinių konstrukcijų katedra \\
\hline 326 & Vaida & Šerevičienė & docentas & pagrindinès & dr. & & Aplinkos apsaugos katedra \\
\hline 327 & Andžela & Šešok & docentas & pagrindinès & dr. & doc. & Biomechanikos katedra \\
\hline 328 & Nikolaj & Šešok & docentas & pagrindinès & dr. & doc. & Poligrafinių mašinų katedra \\
\hline 329 & Irma & Šileikienè & docentas & pagrindinès & dr. & doc. & Informacinių technologijų katedra \\
\hline 330 & Aldis & Šilènas & docentas & antraeilès & dr. & & Fizikos katedra \\
\hline 331 & Agnè & Šimelytė & docentas & pagrindinès & dr. & & İmonių ekonomikos ir vadybos katedra \\
\hline 332 & Česlovas & Šimkevičius & docentas & antraeilès & dr. & & Elektrotechnikos katedra \\
\hline 333 & Juozapas & Šipalis & docentas & pagrindinės & & doc. & Architektūros inžinerijos katedra \\
\hline 334 & Giedrius & Šiupšinskas & docentas & pagrindinès & $\mathrm{dr}$. & doc. & Pastatų energetikos katedra \\
\hline 335 & Jelena & Škamat & docentas & pagrindinès & dr. & & Medžiagotyros ir suvirinimo katedra \\
\hline 336 & Jūratè & Šliogerienè & docentas & pagrindinès & dr. & doc. & $\begin{array}{l}\text { Statybos ekonomikos ir nekilnojamojo turto } \\
\text { vadybos katedra }\end{array}$ \\
\hline 337 & Arnoldas & Šneideris & docentas & pagrindinès & dr. & doc. & $\begin{array}{l}\text { Gelžbetoninių ir mūrinių konstrukcijų } \\
\text { katedra }\end{array}$ \\
\hline 338 & Olga Regina & Šostak & docentas & pagrindinès & dr. & & Inžinerinės grafikos katedra \\
\hline 339 & Valdas & Špakauskas & docentas & pagrindinès & $\mathrm{dr}$. & doc. & Fizikos katedra \\
\hline 340 & \begin{tabular}{|l|} 
Arūnas \\
Mindaugas
\end{tabular} & Šukys & docentas & pagrindinès & dr. & doc. & Mechanikos inžinerijos katedra \\
\hline 341 & Ernestas & Šutinys & docentas & pagrindinės & dr. & & Mechatronikos ir robotikos katedra \\
\hline 342 & Jolanta & Tamošaitienè & docentas & pagrindinès & dr. & doc. & Statybos technologijos ir vadybos katedra \\
\hline
\end{tabular}




\begin{tabular}{|c|c|c|c|c|c|c|c|}
\hline $\begin{array}{l}\text { Eil. } \\
\text { Nr. }\end{array}$ & Vardas & Pavardè & Pareigos & $\begin{array}{l}\text { Pareigu } \\
\text { tipas }\end{array}$ & $\begin{array}{l}\text { Mokslo } \\
\text { laipsnis }\end{array}$ & $\begin{array}{l}\text { Pedagoginis } \\
\text { vardas }\end{array}$ & Padalinys \\
\hline 343 & Romualdas & Tamošaitis & docentas & pagrindinès & dr. & doc. & Statybos technologijos ir vadybos katedra \\
\hline 344 & Andrius & Tamošiūnas & docentas & pagrindinès & dr. & doc. & Socialinès ekonomikos ir vadybos katedra \\
\hline 345 & Rima & Tamošiūnienè & docentas & pagrindinès & dr. & doc. & Finansų inžinerijos katedra \\
\hline 346 & Gintautas & Tamulevičius & docentas & antraeilès & dr. & doc. & Elektroniniu sistemu katedra \\
\hline 347 & Lidija & Tetianec & docentas & antraeilès & dr. & & Chemijos ir bioinžinerijos katedra \\
\hline 348 & Ina & Tetsman & docentas & pagrindinès & dr. & & Mechanikos inžinerijos katedra \\
\hline 349 & Albertas & Timinskas & docentas & antraeilès & dr. & & Chemijos ir bioinžinerijos katedra \\
\hline 350 & Eligijus & Toločka & docentas & pagrindinès & dr. & doc. & Mechanikos inžinerijos katedra \\
\hline 351 & Sonata & Tolvaišienè & docentas & pagrindinès & dr. & doc. & Elektrotechnikos katedra \\
\hline 352 & Jurijus & Tretjakovas & docentas & pagrindinès & dr. & doc. & $\begin{array}{l}\text { Medžiagu atsparumo ir teorinès mechani- } \\
\text { kos katedra }\end{array}$ \\
\hline 353 & Vaidotas & Trinkūnas & docentas & pagrindinès & dr. & doc. & $\begin{array}{l}\text { Statybos ekonomikos ir nekilnojamojo turto } \\
\text { vadybos katedra }\end{array}$ \\
\hline 354 & Justas & Trinkūnas & docentas & pagrindinès & dr. & & Informacinių sistemų katedra \\
\hline 355 & Eva & Trinkūnienè & docentas & pagrindinès & dr. & doc. & Teisės katedra \\
\hline 356 & Natalija & Tumanova & docentas & pagrindinès & dr. & & Matematinio modeliavimo katedra \\
\hline 357 & Inga & Tumasonienè & docentas & pagrindinès & dr. & doc. & Informaciniu technologijų katedra \\
\hline 358 & Živilè & Tunčikienè & docentas & pagrindinès & dr. & doc. & Socialinès ekonomikos ir vadybos katedra \\
\hline 359 & Laura & Tupènaitė & docentas & pagrindinès & dr. & doc. & $\begin{array}{l}\text { Statybos ekonomikos ir nekilnojamojo turto } \\
\text { vadybos katedra }\end{array}$ \\
\hline 360 & Dainius & Udris & docentas & pagrindinès & dr. & doc. & Automatikos katedra \\
\hline 361 & Darius & Ulbinas & docentas & antraeilès & dr. & & Tiltų ir specialiujų statinių katedra \\
\hline 362 & Gitenis & Umbrasas & docentas & pagrindinès & & & Architektūros inžinerijos katedra \\
\hline 363 & Vita & Urbanavičienė & docentas & pagrindinès & dr. & & $\begin{array}{l}\text { Statybos ekonomikos ir nekilnojamojo turto } \\
\text { vadybos katedra }\end{array}$ \\
\hline 364 & Robertas & Urbanavičius & docentas & pagrindinès & dr. & & Mechatronikos ir robotikos katedra \\
\hline 365 & Kęstutis & Urbonas & docentas & pagrindinès & dr. & doc. & Metalinių ir medinių konstrukciju katedra \\
\hline 366 & Jaunius & Urbonavičius & docentas & antraeilès & dr. & & Chemijos ir bioinžinerijos katedra \\
\hline 367 & Ana & Usovaitè & docentas & pagrindinès & dr. & doc. & Grafinių sistemų katedra \\
\hline 368 & Tomas & Ustinavičius & docentas & antraeilès & dr. & & Elektrotechnikos katedra \\
\hline 369 & Rasa & $\begin{array}{l}\text { Ušpalytè- } \\
\text { Vitkūnienè }\end{array}$ & docentas & pagrindinès & dr. & doc. & Miestu statybos katedra \\
\hline 370 & Vaidas & Vadluga & docentas & pagrindinès & dr. & & Automobilių transporto katedra \\
\hline 371 & Marija & Vaičienè & docentas & pagrindinès & dr. & & Statybinių medžiagų katedra \\
\hline 372 & Gediminas & Vaičiūnas & docentas & pagrindinès & dr. & doc. & Geležinkelių transporto katedra \\
\hline 373 & Vaidotas & Vaišis & docentas & pagrindinès & dr. & doc. & Aplinkos apsaugos katedra \\
\hline 374 & Rasa & Vaiškūnaitè & docentas & pagrindinès & dr. & doc. & Aplinkos apsaugos katedra \\
\hline 375 & Audrius & Vaitkus & docentas & pagrindinès & dr. & doc. & Kelių katedra \\
\hline 376 & Saulius & Vaitkus & docentas & pagrindinès & dr. & & Statybinių medžiagų katedra \\
\hline 377 & Kęstutis & Valančius & docentas & pagrindinès & dr. & doc. & Pastatu energetikos katedra \\
\hline 378 & Saulius & Valentinavičius & docentas & pagrindinès & dr. & doc. & Informacinių technologijų katedra \\
\hline 379 & Marina & Valentukevičienè & docentas & pagrindinès & dr. & doc. & Vandentvarkos katedra \\
\hline 380 & Martynas & Valevičius & docentas & pagrindinès & dr. & & Pastatų konstrukcijų katedra \\
\hline 381 & Valdas & Valiūnas & docentas & pagrindinès & dr. & doc. & Automobilių transporto katedra \\
\hline 382 & Vaida & Valuntaitè & docentas & pagrindinès & dr. & doc. & Fizikos katedra \\
\hline 383 & Valentinas & Varnauskas & docentas & antraeilès & dr. & & Medžiagotyros ir suvirinimo katedra \\
\hline 384 & Dominykas & Vasarevičius & docentas & pagrindinès & dr. & & Elektroninių sistemu katedra \\
\hline 385 & Nida & Vasiliauskaitè & docentas & pagrindinès & dr. & & Filosofijos ir politologijos katedra \\
\hline 386 & Virgilija & $\begin{array}{l}\text { Vasilienè- } \\
\text { Vasiliauskienè }\end{array}$ & docentas & pagrindinès & dr. & & Logistikos ir transporto vadybos katedra \\
\hline 387 & Aidas & $\begin{array}{l}\text { Vasilis } \\
\text { Vasiliauskas }\end{array}$ & docentas & pagrindinès & dr. & doc. & Logistikos ir transporto vadybos katedra \\
\hline 388 & Sonata & Vdovinskienè & docentas & pagrindinès & dr. & doc. & Inžinerinès grafikos katedra \\
\hline 389 & Bonifacas & Vengalis & docentas & antraeilès & dr. & doc. & Fizikos katedra \\
\hline 390 & Robertas & Veršinskas & docentas & pagrindinès & dr. & doc. & Kūno kultūros katedra \\
\hline
\end{tabular}




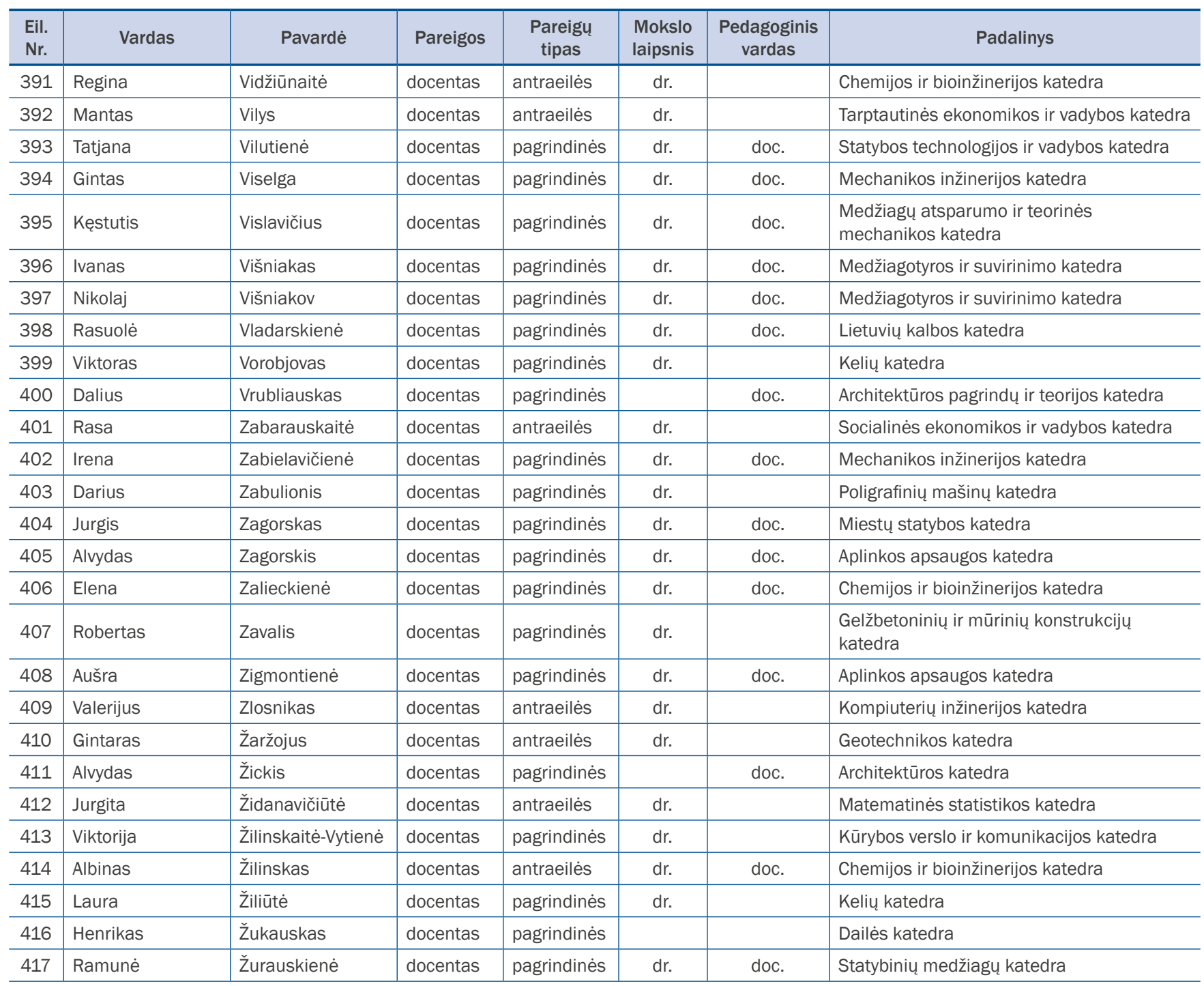


VILNIAUS GEDIMINO TECHNIKOS UNIVERSITETAS 2014 METAI

Mokslas, studijos, universiteto gyvenimas, Nr. 48, 2015

Redaktorè Rita Malikènienè

Maketavo Audronè Gurklienè, Gintautas Bancevičius

Viršelio ir skyrių atsklandų dizainerè Jolanta Šiugždaitė

201503 02. Tiražas pagal poreikị.

Skaitmeninis leidinio variantas su priedais pateikiamas VGTU interneto svetainejje.

Vilniaus Gedimino technikos universiteto leidykla „Technika“,

Saulètekio al. 11, LT-10223 Vilnius

http://leidykla.vgtu.lt

Spausdino BI UAB „Baltijos kopija“,

Kareiviu g. 13B, LT-09109 Vilnius

Dalis knygos lèšu skiriama

$\mathrm{CO}_{2}$ emisijai kompensuoti

ir miškams atsodinti 